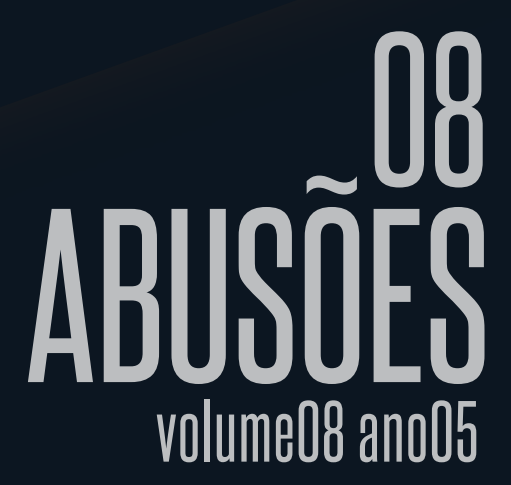




\section{SUMÁRIO}

EDITORIAL

APRESENTAÇÃO DO NÚMERO 05

SERES HUMANOS E NÃO HUMANOS: PERSONAGENS

MARAVILHOSOS/EXTRAORDINÁRIOS

O EXTRATERRESTRE:

ESSE SER MARAVILHOSO DE TODOS OS TEMPOS

A REPRESENTAÇÃO DO OUTRO NO CINEMA FANTÁSTICO: O CASO

DE A FORMA DA ÁGUA (2017), DE GUILLERMO DEL TORO

SAGRADO, DE TOMÁS ELOY MARTÍNEZ:

FIGURAS E MITOS REALISTA MARAVILHOSOS 94

MERLIM, DE ROBERT DE BORON, E O TEXTO RELIGIOSO

"TIRO NÃO O MATA, FOGO NÃO O QUEIMA, ÁGUA NÃO O AFOGA":

AS REFIGURAÇÕES DE MACOBEBA NO MODERNISMO BRASILEIRO

AINULINDALË, THE LORD OF THE RINGS

AND LOTRO: ABOUT TIME

ABALOS NO CORPO, A IMINÊNCIA DE UM MONSTRO?

O CIBORGUE EM NEUROMANCER, DE WILLIAN GIBSON 206

LO MONSTRUOSO NEOFANTÁSTICO DE

SACRILEGIO: LA ONSTRUOSIDAD EN LOS UMBRALES

A CONSTRUÇÃO DO ANTAGONISTA EM OS MAGOS .... 251

ENTREVISTA COM O ESCRITOS RICARDO VIRHUEZ VILLAFANE 283 
UM CONVITE ÀS MONSTRUOSIDADES EM VIALE MOUTINHO 290 ONZE HISTÓRIAS E UM SEGREDO: DESVENDANDO AS LENDAS AMAZÔNICAS. TAÍSA APARECIDA CARVALHO SALES. 2016 309 NÓS, CIBORGUES: O CORPO ELÉTRICO E A DISSOLUÇÃO DO HUMANO ANTROPOLOGIA DO CIBORGUE: AS VERTIGENS DO PÓS-HUMANO - DONNA HARAWAY, HARI KUNZRU, TOMAZ TADEU (ORG.). 2016 


\section{EDITORIAL}

As artes da abusão: dos erros de percepção, das coisas que se tomam por outras, das ilusões e dos enganos; da crença no fantástico e das superstições; dos feitiços, dos esconjuros e dos malefícios. Foi em torno dessa hoje exótica palavra que nasceu a Abusões, revista dedicada às ficções que transitam nas franjas do real, um projeto que é fruto da parceria entre dois Grupos de Pesquisa certificados pela Universidade do Estado do Rio de Janeiro (UERJ) junto ao Diretório de Grupos do Conselho Nacional de Desenvolvimento Científico e Tecnológico (CNPq), o Nós do Insólito: Vertentes da Ficção, da Teoria e da Crítica e o Estudos do Gótico.

O vigor desse campo de estudos nas universidades brasileiras é atestado pelo surgimento e consolidação, nos últimos anos, de vários grupos de pesquisa a ele dedicados, como o Vertentes do Fantástico na Literatura (UNESP), o Espacialidades Artísticas (UFU), o Língua e literatura: interdisciplinaridade e docência (UNIFESP) e o Narrativa e insólito (UFU), todos reunidos, juntamente com nossos dois grupos da UERJ, no GT da Associação Nacional de Pós-graduações e Pesquisa em Letras e Linguística Vertentes do Insólito Ficcional.

Dessas inúmeras e labirínticas intersecções e tangências entre o insólito, o gótico, o fantástico, o medo, o estranho, o maravilhoso, o horror, a fantasia, o sobrenatural, vêm os artigos que dão corpo à publicação. Interessa veicular os resultados de pesquisas dessa vasta rede de estudos, seja como um instrumento de divulgação, seja como um ambiente crítico, capaz de integrar trabalhos individuais em projetos coletivos. 
Abusões é uma publicação semestral, hospedada no Portal de Publicações Eletrônicas da UERJ, e tem por finalidade a divulgação de artigos, resenhas, entrevistas e fontes documentais relevantes para os estudos do Gótico, do Fantástico e do Insólito. A revista publica textos em Português, Espanhol, Francês, Italiano, Inglês e Alemão, de autoria de pesquisadores e professores doutores ou doutorandos em coautoria com seus orientadores.

Editores Gerentes

Flavio García (UERJ) Líder do GP Nós do Insólito: Vertentes da Ficção, da Teoria e da Crítica Júlio França (UERJ) Líder do GP Estudos do Gótico 


\section{APRESENTAÇÃO}

Marisa Martins Gama-Khalil (UFU/CNPq)

Sylvia Trusen (UFPA)

Desde a Antiguidade Clássica, personagens míticas, legendárias, mágicas, maravilhosas vêm povoando a ficção. A epopeia clássica se erigiu apoiada em tempos, espaços e personagens olímpicos, cujas ações desmediam-se para além das capacidades humanas. A épica medieval ressignificou os aspectos advindos da tradição clássica e lhes acrescentou novos elementos oriundos das culturas celta e cristã, por exemplo, com dragões, mulas sem cabeça, castelos assombrados, florestas enevoadas em tempos do era uma vez. Em boa medida, a retomada romântica do medievo deu novos impulsos àquelas vertentes ficcionais, ambientadas em cenários demarcados pelo sentimento imanente de nacionalidade, fosse no Velho, fosse no Novo Mundo. Enriquecendo-se a cada passo, verificou-se a onipresença de fadas, duendes, elfos, gnomos e outros tantos seres maravilhosos na ficção de todos os tempos, migrando da literatura, em seu sentido lato, para o cinema, depois de seu advento na viragem do Século XIX para o $X X$ e, a seguir, para a televisão, quando de sua difusão no segundo quartel dos Novecentos. Mais recentemente, as tecnologias cibernéticas e as redes digitais permitiram ainda maior profusão dos universos míticos, legendários, mágicos, maravilhosos, envolvendo sujeitos emissores ou receptores muito mais distintos.

Assim, os seres maravilhosos povoam a ficção fantástica desde 
os tempos mais remotos até este nosso milênio, constituindo-a como um território de mirabilia. Nos contos de fadas, é obrigatória a presença de seres dotados de caracteres mágicos, como fadas, bruxas, personagens com dons sobrenaturais. Nas narrativas orais populares e nas lendas - desde as tradicionais às urbanas -, os seres sobrenaturais situam-se no centro dos enredos; seres maravilhosos como o lobisomem, o saci-pererê, a mula-sem-cabeça, o mapinguari, o boto, a loira do banheiro, configuram-se como elemento narrativo principal, porquanto, sem elas, o enredo esvazia-se. Pode-se dizer que os seres maravilhosos criam uma força gravitacional, na medida em que, nas narrativas de que fazem parte, eles funcionam como o sentido da trama. Na ficção de terror, também os monstros funcionam como alicerce, como sustentáculo da narrativa, pois a história existe porque eles existem. Não é possível pensar na série de filmes Sexta-feira 13 sem acionar imediatamente a figura de Jason Voorhees; sem Jason a trama esgota-se e é por esse motivo que a ele é conferida uma certa imortalidade: quando o expectador pensa que Jason morreu no fim de um dos filmes, ele ressurge no outro, muitas vezes mais potente e dotado de uma maior força de atração em relação ao público, que, a um só tempo, o teme e o espera. Nas ficções literárias e fílmicas de Drácula essa mesma força paradoxal da atração e da repulsão faz-se presente, pois o conde é sedutor e, ao mesmo tempo, aterrorizador. Seu poder de atração é tamanho a ponto de ter gerado um número altíssimo de narrativas fílmicas e literárias. Na ficção científica, alienígenas e robôs compõem o mapa humano das narrativas. Como explica Adam Roberts, com base em Darko Suvin, em A verdadeira história da ficção científica, eles são o novum - o elemento que põe em evidência a diferença entre o 
mundo do leitor e o da ficção. Essa diferença parece instigar no leitor da ficção científica o desejo de experimentar, por intermédio da diegese, novas possibilidades de relacionamento entre humanos e não humanos ou, como defendia Alfred Hitchcock, vivenciarmos as circunstâncias ameaçadoras e amedrontadoras em contato com esses seres maravilhosos - e por vezes monstruosos - sem termos que "pagar o preço":

Para cada pessoa que busca o medo no sentido real, pessoal, há milhões que o procuram de forma indireta, no teatro e no cinema. Nos auditórios escuros, identificam-se com os personagens fictícios que estão sentindo medo, e experimentam, eles próprios, as mesmas sensações (o pulso acelerado, a palma da mão alternadamente seca e úmida etc.), mas sem ter que pagar o preço. Que o preço não precise ser pago - na verdade, não deva ser pago é o que importa (HITCHCOCK, 1998, p.145)

Podemos considerar todos esses seres a partir da fenomenologia metaempírica exposta por Filipe Furtado. No verbete destinado ao Modo Fantástico no E-dicionário de termos literários de Carlos Ceia, o teórico português explica que o metaempírico é constituído de elemento e/ou acontecimentos indetectáveis e incognoscíveis. É mais abrangente do que a noção de sobrenatural, no ponto de vista de Furtado, pois abarca um conjunto mais amplo de figuras e contextos. O termo "recobre não só as manifestações de há muito denominadas sobrenaturais, mas, ainda, outras que, não o sendo, também podem parecer insólitas e, eventualmente, assustadoras" (FURTADO, 2011). Nessa linha de entendimento, inserem-se os seres maravilhosos que habitam as ficções de todos os tempos e são o objeto de estudo dos artigos deste número da Abusões. 
O contato dos leitores e dos expectadores com os seres maravilhosos - e com toda ficção metaempírica - tem a função de compensação apontada por Jacques Le Goff, já que o "maravilhoso é um contrapeso à banalidade e à regularidade do quotidiano", e, por isso, as narrativas nas quais eles habitam têm enorme impacto na recepção de todos os tempos, persistindo na nossa. Seja incitados pela sedução, pelo medo ou pela curiosidade, continuamos atraídos por esses seres maravilhosos.

O presente dossiê tem como fito refletir sobre como ocorreu o percurso desses seres maravilhosos em distintos tempos e espaços, quais foram ou são seus processos de produção ou seus impactos de recepção, que relações se podem estabelecer com outros campos da arte ou discursos do saber, o que se tem como perspectivas para seu porvir. 


\section{SERES HUMANOS E NÃO HUMANOS: PERSONAGENS MARAVILHOSOS/ EXTRAORDINÁRIOS ${ }^{1}$}

Heloisa Helena Siqueira Correia (UNIR)

Recebido em 08 dez 2018. Heloisa Helena Siqueira Correia é Doutora em Teoria Aprovadoem 11 fev 2019. e História Literária pela UNICAMP, 2006. UNIRCampus de Porto Velho. Programa de Mestrado em Estudos Literários, áreas de atuação: Mitologia indígena, Literatura Amazônica, Fantástico Literário. Grupo de Pesquisa em Estudos Literários- UNIR; (GT-ANPOLL) - Vertentes do insólito ficcional. Áreas de Interesse: Literatura e Filosofia, obra de Jorge Luis Borges, Estudos Animais e Ecocrítica. Lattes: http://lattes.cnpq.br/0099522992282652. E-mail: heloisahelenah2@hotmail.com.

Resumo: O texto objetiva acompanhar o processo textual/cultural que se afasta do território do mito, preservando os seres não humanos (e míticos) em suas culturas próprias, ao passo que, respeitadas as fronteiras (que não se fundem), promove a criação de personagens ficcionais extraordinários/ maravilhosos. Os personagens em foco são, ambos, habitantes da obra de Jorge Luis Borges. 0 minotauro de La casa de Asterión (1994, p.569-570), cuja característica antiga é o hibridismo (corpo de homem e cabeça de touro) sobrevive no mito grego,

1 Título do artigo em inglês: "HUMAN AND NONHUMAN BEINGS: WONDERFUL/ EXTRAORDINARY CHARACTERS" 
enquanto a literatura cria um personagem ambíguo, maravilhoso, melancólico e solitário; e o jaguar de La escritura del Dios (1994, p.596-599), animal natural e sagrado que vive na cultura de variadas etnias sul americanas, enquanto a literatura cria um personagem extraordinário, excepcional, depositário dos signos divinos. A direção de leitura, portanto, demonstra que a cultura universal do escritor não interfere na cultura nativa, e para isso retoma momentos diversos dos contos. O texto defende, ainda, que literatura e mito não se fundem, antes a literatura trabalha para o mito, nos obrigando a ir em busca da memória da cultura de origem, no caso a grega e a sul-americana. Dialoga-se com autores como Rosalba Campra (2016), Maria João Simões (2018), Leonardo Padura (1989), Sérgio Medeiros (2007) e Federico Naraverrete (2006), entre outros. Palavras-chave: Ser não humano; Personagem maravilhosa; Cultura nativa; Literatura; Jorge Luis Borges.

Abstract: The text aims to follow the textual/cultural process that moves away from the territory of the myth preserving the nonhuman (and mythical) beings in their own cultures, while respecting the boundaries (that do not merge) promote the creation of extraordinary/wounderful fictional characters. The characters in focus are both inhabitants of the work of Jorge Luis Borges. The minotaur of La casa de Asterión (1994, p.569-570), whose old feature is hybridism (man's body and bull's head) survives in the Greek myth, while literature creates an ambiguous, wonderful, melancholy and lonely character; and the jaguar of La escritura del Dios (1994, pp.596-599), a natural and sacred animal that lives in the culture of various South American ethnicities, while literature creates an extraordinary, exceptional character, depositary of the divine signs. The reading direction, therefore, demonstrates that the writer's universal culture does not interfere with native culture, and for 
this it takes up different moments from the stories. The paper also argues that literature and myth do not merge, but literature works for myth, forcing us to go in search of the memory of the culture of origin, in the case of Greek and South American. So I dialogue with authors like Rosalba Campra (2016), Maria João Simões (2018), Leonardo Padura (1989), Sérgio Medeiros (2007) and Federico Naraverrete (2006), among others.

Keywords: Nonhuman; Wonderful character; Native culture; Literature; Jorge Luis Borges.

A morada do homem, o extraordinário.

Heráclito

Em se tratando de personagens fictícias maravilhosas que se pode encontrar na literatura, os seres que encantam leitores povoam os mundos "reais" e possíveis. São muitos os seres que, de origem cultural diversa, de tempos históricos diferentes, se fazem presentes em literaturas dos mais variados países. Nosso primeiro passo, portanto, será a seleção das personagens a serem estudadas. A escolha incide sobre personagens cujas qualidades, formas e ações são estranhas e admiráveis, e cuja natureza transita entre a excepcionalidade e a animalidade, entre o extraordinário e o animal.

Referimo-nos a dois personagens que se encontram nos seguintes textos de Jorge Luis Borges: La casa de Asterión (1994, p.569-570), cuja personagem híbrida que possui corpo de homem e cabeça de touro, é recriada dando origem a um minotauro melancólico, demonstrando intertexto com a cultura grega e La escritura del Dios (1994, p.596-599), em que o jaguar, animal sagrado na cultura de variadas etnias americanas, é o depositário fiel da 
escritura de Deus. Ambos os personagens foram dominados pela norma social violenta e estão encarcerados. A direção escolhida, portanto, parte da cultura universal do escritor para chegar ao solo da cultura nativa sul-americana.

A princípio consideramos necessário pontuar algumas relações históricas do maravilhoso europeu e a realidade americana. Partimos então, da memória de que, em determinado sentido, o maravilhoso como adjetivo atribuído a seres, lugares e acontecimentos aportou em terras hoje denominadas americanas, no século XV-XVI, trazido pelas caravelas, instalado na mente dos viajantes e colonizadores europeus. A atribuição de maravilhas à realidade das Américas, deve-se, em um primeiro momento, ao imaginário europeu, cultivado desde a antiguidade.

A história das guerreiras Amazonas conhecida desde Heródoto, por exemplo, é emblema de como o imaginário europeu encontrou, nas Américas, aquilo que já postulava como existente nas novas terras. Entre outras, encontramos referências a tais mulheres durante a expedição de Francisco Orellana a partir do Peru em 1542 (RALEIGH, 2017, p.128) e durante a viagem de Walter Raleigh, iniciada em 1595.

Areferência às mulheresasapresenta como extraordinariamente poderosas, corajosas e independentes do poder patriarcal (RALEIGH, 2017, p.62). Nesse sentido, o maravilhoso europeu atravessa os oceanos e ao estar em terra firme americana alimenta-se da realidade histórica e da cultura nativa dos povos originários. No caso da existência das Amazonas, a cultura nativa involuntariamente lhe fornece a materialidade física que faltava, pois que, ao que indicam os depoimentos e relatos dos Orinoquinos feitos a Raleigh (2017, 
p.62), existiram tribos exclusivamente femininas, de guerreiras indígenas, na mesma região referida pelos relatos. A figuração de tais guerreiras, no entanto, no caso da cultura nativa, não parece guardar elo algum com o maravilhoso europeu. Outro exemplo do suposto maravilhoso buscado por viajantes pode ser encontrando na suposição da existência de loci maravilhosos, cuja maravilha ligase à riqueza e à abundância, como El Dorado, a cidade de ouro, chamada Manoa pelos nativos (RALEIGH, 2017, p.29). Manoa teria sido vista primeiramente por Juan Martínez, que a teria nomeado El Dorado (RALEIGH, 2017, p.52-55).

Afora o maravilhoso deslocado de terras europeias, mas ainda com denominação semelhante, o maravilhoso americano, por sua vez, é identificado de outro modo. A esse respeito, embora polêmica e exaustivamente estudada, a concepção de Alejo Carpentier, objeto de reflexão de Leonardo Padura, é pertinente:

lo maravilloso comieza a serlo de manera inequívoca cuando surge de una inesperada alteración de la realidade (el milagro), de una revelación privilegiada de la realidade, de una iluminación inabitual o singularmente favorecedora de las inadvertidas riquezas de la realidade, de una ampliación de las escalas y categorias de la realidade percebidas con particular intensidade en virtude de una exaltación del espiritu que lo conduce a un modo de "estado limite". (1989, p.29)

O maravilhoso, nesse sentido, está no coração do real, e cada vez que a experiência ou sensação do real descortina uma alteração e uma ampliação, cada vez que algo se revela ou é iluminado de modo singular, o maravilhoso aflora ao mesmo tempo que o sujeito envolvido atinge um "estado limite". Resta saber com que olhos 
Carpentier refere-se ao real. A perspectiva cultural, por certo, é uma das inúmeras determinações que balizam a experiência/sensação.

Pensemos por um momento nos seres que, desde antes do contato, convivem cultural e etnologicamente com os povos que Ihes respeitam. Os seres que habitam a cultura nativa, de matriz não ocidental, são muitas vezes chamados de maravilhosos por sujeitos participantes da cultura de matriz ocidental, o que não se aplica às etnias cuja cultura é de matriz não ocidental, pois que, do seu ponto de vista, essa não será uma denominação adequada para os espíritos dos ancestrais, os seres sagrados e em metamorfose, as plantas poderosas que falam e curam, os animais que dialogam com os humanos e os ensinam técnicas fundamentais para a alimentação; e também os objetos, muitas vezes protagonistas e autônomos. Não se pode afirmar, então, que sujeitos indígenas vivam a experiência com o maravilhoso. Padura novamente lança luz sobre a questão:

la sensación de lo maravilloso, o mejor, la capacidade para determinar qué es lo marailloso, más que de una fe, proviene de um exhaustivo conocimiento de lo insólito y lo lógico, de lo americano y lo universal entrelazados en la realidade de nuestro continente. (1989, p.33)

Não é difícil perceber que quem conhecerá o insólito, em contraposição ao lógico é um sujeito que manipula as categorias duais do pensamento ocidental. Em direção contrária, enfatiza-se, então, que no contexto dos povos originários das Américas, os animais, as plantas, os espíritos dos mortos e os objetos não são maravilhosos ou fictícios em sentido estrito, pois que compartilham da mesma natureza ordinária dos humanos, e detém poderes - inclusive de 
criação-, além de protagonismo, divindade e subjetividade. Isso diz respeito aos animais de modo especial, pois são considerados exhumanos e parentes por muitos povos.

Há que se reconhecer, entretanto, que quando tais seres são deslocados de sua realidade ontológica e adentram a tessitura ficcional de narrativas literárias, quando são relidos, recriados, apropriados e transfigurados e mudam de território, migram para a literatura, tornam-se tributários da ficção e transformamse em personagens. Como reconhece Padura, agora "[...] ya no es posible, como antes, encontrar lo maravilloso al estado bruto, ya hecho, preparado, mostrado, sino que es necessário entreverlo en las circusntancias reflejadas, en el espíritu de una ciudad, en el comportamento de un personaje." (1989, p.51). Somente nesse sentido, são personagens que a partir de nossa cultura podemos, inclusive, chamar maravilhosos, extraordinários e excepcionais, sem que, com isso, estejamos impondo uma conceituação ocidental sobre a cultura não-ocidental, pois que já se tratam de outros seres. Essa parece ser a situação do jaguar recriado como personagem ficcional jaguar em La escritura del Dios. E também dos seres cuja natureza é transferida do mito para a ficção, como o minotauro de La casa de Asterión.

Diferente do perspectivismo que, de acordo com Eduardo Viveiros de Castro (2002, p.353), não se refere a todos os animais, mas principalmente aos grandes predadores e os carniceiros como o jaguar, a sucuri, o urubu, a harpia, e os que são objetos da predação humana - como o pecari, as antas, os peixes, os veados, os macacos, a ficção literária, assim como a poesia, pode forjar subjetividades de todos os animais. 


\section{ANIMAL HÍBRIDO GREGO: HUMANO E NÃO-HUMANO}

Em La casa de Asterión, conto notável de Jorge Luis Borges, da coletânea Aleph, de 1949, o animal humano/não humano conhecido como minotauro, é recriado em perspectiva de subjetivação. A rudeza do personagem convive com sentimentos de melancolia, solidão e esperança. A história grega acerca de Minos, o minotauro, Teseu e Ariadne reflete objetividade discursiva, e o personagem híbrido não possui voz ou vida interior. A esse respeito, vale lembrar o trabalho de Rosalba Campra, ao debruçar-se sobre modos diversos do silencio e da voz da criatura fantástica, em diferentes momentos históricos, o que se assemelha ao que ocorre com a criatura mítica no interior da narrativa antiga. Segundo a pesquisadora, "Na tradição da literatura fantástica, os caminhos que o texto propõe ao leitor são, obviamente, os da personagem humana, não os da personagem outra" (CAMPRA, 2016, p.154), de modo semelhante, a narrativa mítica dá preferência ao ponto de vista humano, e não do monstro.

Em sentido complementar, a pesquisadora indica o motivo pelo qual o humano abafa a perspectiva do outro, porque suspeita que "[...] Se tivéssemos a fraqueza de escutar suas razões, não correríamos o risco de terminar cedendo totalmente nosso espaço? Não terminaríamos reconhecendo-o como um de nós?" (CAMPRA, 2016, p.154), o que demonstra que o controle antropocêntrico do ponto de vista narrativo é um tipo de defesa do narrador humano, além de uma estratégia de apagamento da diferença em nome da preservação majoritária do mesmo.

O conto borgeano, entretanto, insere-se já em contexto de renovação dos procedimentos narrativos. Segundo a pesquisadora, 
desde a segunda metade do século XX, ocorre uma "[...] revisão das posições etnocêntricas que impediam aceitar - e até simplesmente considerar - os valores e os sistemas do outro" (CAMPRA, 2016, p.155), concedendo, muitas vezes, o ponto de vista narrativo à outridade. Daí a percepção de que o personagem da história borgeana, cujo ancestral faz adivinhar o ser mítico, não é só o dono da voz narrativa, mas também é portador de subjetividade não simplesmente humana, mas uma subjetividade própria (de um ser híbrido) forjada pelo autor.

Em perspectiva de palimpsesto, então, o leitor continua a identificar o ser do mito grego sob o conto do escritor argentino, o ser que não é o personagem, por certo. A pesquisadora Suzi Frankl Sperber, ao refletir sobre o fato de a forma do mito carregar o desejo humano de escapar à força de Tânatos, assevera: "O mito reconhece a palavra e a produção artística como força do ciclo vital. A pulsão de ficção- isto é, a criação - gera produtos cuja permanência supera a morte (VOLOBUEF, 2011, p.20)". Em outras palavras, para que o mito não se extinga, entram em cena as derivadas variações ficcionais.

De acordo com a memória do mito em questão, retomada por Junito de Souza Brandão em Mitologia grega, volume I, quando Minos disputa o governo de Creta com seus irmãos, Poseidon o apoia atendendo ao pedido que o humano lhe fez: de que saísse do mar um grande touro, o qual, em seguida Minos sacrificaria ao deus do mar. Poseidon cumpre sua parte no acordo fazendo sair do mar um grande e belo touro, o que permite que Minos demonstre, assim, aos seus concorrentes, que seu governo é da vontade dos deuses. Entretanto, o rei não realiza o sacrifício, encantado com a beleza do animal, pretende preservar-Ihe a raça (BRANDÃO, 1986, p.62). 
Segue-se a vingança de Poseidon que, além de enfurecer o animal, fará com que Pasífae, esposa de Minos, rei cretense, apaixone-se pelo touro. A mulher teria obtido auxilio do grande artista, escultor, arquiteto e inventor ateniense Dédalo que the fabricara uma novilha de bronze capaz de enganar o animal, objeto de paixão proibida. Então: "Pasífae colocou-se dentro do simulacro e concebeu do touro um ser monstruoso, metade homem, metade touro, o Minotauro" (BRANDÃO, 1986, p.62). O filho do adultério será escondido por Minos no labirinto, também construído por Dédalo, e será alimentado com carne humana. Jean Pierre Vernant, retomado por Sperber, explicita os motivos: "[...] o mito tem o papel de reforçar a coesão social, a unidade funcional do grupo, apresentando e justificando, em uma forma codificada, de audição agradável, de fácil memorização, de modo a ser transmitida, de geração a geração, a ordem tradicional das tradições e das condutas" (VERNANT, Apud VOLOBEUF, 2011, p.17). Hibrys de Minos se manifesta em prepotência e de Pasifae encarna-se no desejo incontrolável, ambos são punidos pelo deus para que a ordem e a medida possam se restabelecer, e a narrativa se torna exemplar quanto à correta conduta do grupo social.

O traiçoeiro Dédalo, além de construir a novilha que possibilitou a traição de Pasifae, também planejava, em conjunto com Ariadne, filha de Minos, a libertação de Teseu, filho do rei ateniense Egeu, inimigo do rei cretense. Tal animosidade se deve à morte, durante jogos em que participam atenienses e cretenses, de Androgeu, filho de Minos, que atribui a perda do filho a Egeu. Brandão explica: "Como a luta se prolongasse e uma peste (pedido de Minos a Zeus) assolasse Atenas, Minos concordou em retirar-se, desde que, 
de nove em nove anos, lhe fossem enviados sete rapazes e sete moças, que seriam lançados no Labirinto, para servirem de pasto ao Minotauro" (1986, p.62). Assim, inicia-se o ritual de sacrifício de jovens à criatura meio animal meio homem, que só terá fim quando Teseu, ao entrar no labirinto como uma das vítimas masculinas, matar o Minotauro.

Percebe-se claramente que o mito não aborda o ser monstruoso, ele é o centro motivador da história sem que se saiba algo a seu respeito, afinal, qual seria a perspectiva de um filho da traição, de estirpe real, bastardo que possui forma horrível, que carrega em si o estigma do fracasso de Minos e o desejo proibido da mãe? Punido pelo rei, seu padrasto, torna-se responsável pelo sacrifício de inocentes, odiado por atenienses: "Os sacrifícios ao monstro são outras tantas mentiras e subterfúgios para adormecê-lo e outras tantas faltas que se acumulam" (BRANDÃO, 1986, p.63). 0 ser híbrido é aprisionado por motivação moral? O que deseja essa criatura que os homens temem e difamam?

O leitor não encontrará todas as respostas no conto borgeano, mas o texto toca questões, sentimentos, virtudes e defeitos fundamentais do ser tornado personagem, que, ao deslocar-se do território do mito, renasce, para o terreno que os olhos ocidentais denominam maravilhoso, excepcional ou extraordinário. Ao longo do conto, várias serão as passagens que nos darão pistas e ao mesmo tempo atalhos falsos. Maria João Simões, ao tratar das personagens da ficção fantástica colabora na reflexão sobre o personagem ficcional maravilhoso, na medida em que a estudiosa elenca cinco procedimentos que promovem a criação da personagem. $\mathrm{O}$ que chamamos pistas falsas, por exemplo, pode ser relacionado ao 
que Simões denomina "Procedimentos por ambiguidade": "O procedimento por ambiguidade, no que toca à configuração das personagens, revela-se através de estratégias conhecidas, como a estratégia da duplicidade e da indefinição categorial" (SIMÕES In GARCIA et al, 2018, p.61). Incluem-se aí as personagens híbridas (centauros, sereias, elfos, duendes, entre outros), aí localizamos também Asterión. A pesquisadora ainda menciona os personagens que carregam "confusão categorial" como o homem-bicho, homemobjeto e o morto-vivo, por exemplo (GARCIA et al, 2018, p.61), o que também pode ser relacionado ao personagem borgeano, metade homem, metade animal.

O leitor, que por algum motivo não relacione o nome Asterión com a mitologia grega, percebe passo a passo, desde o início do conto, certa estranheza no perfilamento do personagem. A auto apresentação de narrador-personagem inquieta por ambígua, elíptica, talvez metafórica:

Sé que me acusan de soberbia, y tal vez de misantropía, y tal vez de locura. Tales acusaciones (que yo castigaré a su debido tiempo) son irrisorias. Es verdad que no salgo de mi casa, pero también es verdad que sus puertas (cuyo número es infinito) están abiertas día y noche a los hombres y también a los animales. Que entre el que quiera. No hallará pompas mujeriles aqui ni el bizarro aparato de los palacios pero si la quietud y la soledad. Asimismo hallará una casa como no hay otra en la faz de la tierra. (Mienten los que declaran que en egipto hay una parecida). Hasta mis detractores admiten que no hay un solo mueble en la casa. Otra especie ridicula es que yo, Asterión, soy un prisionero. ¿Repetiré que no hay una puerta cerrada, anadiré que no hay una cerradura? (BORGES, 1994, p.569) 
Abre-se a possibilidade de que o leitor esteja frente a frente com um personagem soberbo, misantropo, louco, e, ambiguamente (agora a ambiguidade relaciona-se ao caráter do personagem), acolhedor (as portas de sua casa estão sempre abertas a todos), frugal (sua casa não conta com enfeites femininos e palacianos), solitário e prisioneiro em sua própria casa.

Na sequência, quando o narrador-personagem refere-se a uma ocasião em que saíra de sua casa, por exemplo, o leitor sente estranhamento em relação ao modo como o narrador se refere à aparência física dos humanos, o que inversamente torna manifesto que o narrador reconhece-se como diferente deles:

Algún atardecer he pisado la calle; si antes de la noche volví, lo hice por el temor que me infundieron las caras de la plebe, caras descoloridas y aplanadas, como la mano abierta. Ya se había puesto el sol, pero el desvalido Ilanto de un niño y las toscas plegarias de la grey dijeron que me habían reconocido. La gente oraba, huía, se posternaba; unos se encaramaban al estilóbato del templo de las Hachas, otros juntaban piedras. Alguno, creo, se ocultó en el mar. No en vano fue una reina mi madre; no puedo confundirme con el vulgo, aunque mi modestia lo quiera. (BORGES, 1994, p.569)

Estão aí as sensações do personagem: medo da plebe e ironia ao referir-se a uma modéstia pouco provável para um príncipe. Também a reação dos humanos plebeus ao encontra-lo: terror e fuga. Até aqui, frente ao leitor está um personagem bastante controverso. $\mathrm{O}$ texto é rico em tergiversações e digressões que brincam com o leitor, postergando a identificação inequívoca do personagem. 
O conto explicitamente oscila em ambiguidades: um príncipe que parece que se retira voluntariamente à sua casa, mas também sofre de solidão? Não é possível ao leitor até aqui, encontrar uma intersecção das qualidades do personagem de modo a visualizálo como personagem coeso. A passagem abaixo nos apresenta detalhes a esse respeito:

El hecho es que soy único. No me interesa lo que un hombre pueda trasmitir a otros hombres; como el filósofo, pienso que nada es comunicable por el arte de la escritura. Las enojosas y triviales minucias no tienen cabida en mi espiritu, que está capacitado para lo grande; jamás he retenido la diferencia entre una letra y otra. Cierta impaciencia generosa no ha consentido que yo aprendiera a leer. A veces lo deploro, porque las noches y los días son largos. (BORGES, 1994, p.569)

É perceptível ao leitor um temperamento deveras desiquilibrado que não se sabe bem ao certo se é de um sábio que se recolheu em sua casa e abriu mão de seu reinado, ou um vaidoso, impaciente e pessimista príncipe, que vê o mundo hierarquizado, inclusive no que diz respeito às inclinações, a dele, claro, uma inclinação ao grande que lhe impede de voltar-se a detalhes e miudezas. E embora o texto faça menção à generosidade, parece que é apenas para relativizar que o narrador, por muita impaciência, não é capaz de aprender a ler.

A despeito de tais informações, novamente o leitor suspende seu já pouco conhecimento da personagem ao ler, em seguida, que o personagem possui um espírito infantil que o estimula a brincar sozinho pelas galerias ou com um visitante imaginário, um outro Asterión, invisível, digamos. E, após essa revelação de inocência, surge um parágrafo cujo tom é, explicitamente, de uma especulação filosófica: 
he meditado sobre la casa. Todas las partes de la casa están muchas veces, cualquier lugar es otro lugar. No hay un aljibe, un patio, un abrevadero, un pesebre; son catorce [son infinitos] los pesebres, abrevaderos, patios, aljibes. La casa es del tamaño del mundo; mejor dicho, es el mundo. Sin embargo, a fuerza de fatigar patios con un aljibe y polvorientas galerías de piedra gris he alcanzado la calle y he visto el templo de las Hachas y el mar. Eso no lo entendí hasta que una visión de la noche me reveló que también son catorce [son infinitos] los mares y los templos. Todo está muchas veces, catorce veces, pero dos cosas hay en el mundo que parecen estar una sola vez: arriba, el intrincado sol; abajo, Asterión. Quizá yo he creado las estrellas y el sol la enorme casa, pero ya no me acuerdo. (BORGES, 1994, p.570)

Neste momento, é o narrador-filósofo que toma a voz, elevando sua casa à equivalência com o mundo, o que sugere que, referencialmente, o mundo do leitor é um labirinto. Narrador que se sabe único como o sol, sugere ser um deus esquecido do momento da criação. O excerto mostra, então, a imagem nada modesta que o personagem tem de si mesmo, e apresenta o uso da simbologia do número 14 como "infinito".

O texto borgeano avança pela perspectiva do olhar do narrador que recebe em sua casa, de nove em nove anos, nove pessoas desconhecidas que ele mesmo mata, o inusitado ao leitor fica por conta do vaticínio feito por uma de suas vítimas. De acordo com o narrador, "Cada nueve años entran en la casa nueve hombres para que yo los libere de todo mal. [...] Ignoro quiénes son, pero sé que uno de ellos profetizó, en la hora de su muerte, que alguna vez llgaría mi redentor" (BORGES, 1994, p.570). 
Torna-se gritante a inversão de perspectiva: o que para os atenienses é um sacrifício hediondo, para o personagem é uma ação salvadora, a morte de nove homens levada à cabo, provavelmente, pela boca (já que suas mãos não se sujam com sangue). E, ainda, na atribuição do papel de redentor ao homem que matará o personagem.

A criação da tensão que já é parte do desfecho do conto envolve esperança e questionamento acerca da identidade do suposto redentor e de si mesmo:

Desde entonces no me duele la soledad, porque sé que vive mi redentor y al fin se levantará sobre el polvo. Si mi oído alcanza todos los rumores del mundo, yo percibiría sus pasos. Ojalá me lleve a un lugar con menos galerías y menos puertas. ¿Como será mi redentor?, me pregunto. ¿Será un toro o un hombre? ¿Será tal vez un toro con cara de hombre? ¿O será como yo?

El sol de la mañana reverberó en la espada de bronce. Ya no quedaba ni un vestigio de sangre.

-¿Lo creerás, Ariadna? - dijo Teseo-. El minotauro apenas se defendió. (BORGES, 1994, p.570)

Acima, a excepcionalidade de nosso narrador personagem, a confirmação para o leitor: de que Asterión, personagem meio animal, meio homem, da cultura grega antiga, transformou-se em um personagem, sujeito (contemporâneo?), cuja vida interior é rica em dúvidas, sensações, sonhos e reflexões. Em outras palavras, o leitor pode compreender que o minotauro transformou-se em um "eu". Mas como é comum ao leitor borgeano, ele precisa suspeitar, por isso pergunta: transformar-se em eu significa que a humanidade predominou sobre seu hibridismo? Ou inversamente é um símbolo 
de que os humanos monstruosos (inclusive política e socialmente) possuem subjetividade, discurso, reflexões filosóficas e nem por isso deixam de agir com violência?

A animalidade em La casa de Asterión subjaz à narrativa pois no palimpsesto que o leitor adivinha, ele é filho de um touro e de uma rainha. O minotauro é a um só tempo personagem animal extraordinário e personagem humano extraordinário. Pela boca de touro ele fala, com a cabeça animal especula filosoficamente, e com olhos animais relaciona-se com o mundo, sempre tendo como ponto de partida um "eu". Com o corpo humano, por sua vez, ele corre entre os corredores de sua casa labiríntica, para brincar e para matar. Até aqui nossa leitura acompanhou passo a passo o comportamento, os pensamentos e os sentimentos de um personagem mítico que se deslocou para o território da literatura, adquirindo ali outro modo de ser, outra perspectiva e outros valores.

\section{ANIMAL DUPLO SUL-AMERICANO: HUMANO E NÃO HUMANO}

O conto borgeano La escritura del Dios nos apresenta dois personagens, um animal humano e um não-humano que, lado a lado, dividem um cárcere, o tempo e a vida, são eles: "Tzinacán, mago de la pirámide de Qaholom, que Pedro de Alvarado incendió" e "un jaguar, que mide con secretos pasos iguales el tiempo y el espacio del cautiverio" (BORGES, 1994, p.596). O espaço da cela é iluminado todos os dias, ao meio-dia, quando o suposto carcereiro faz descer a comida e a água aos prisioneiros, por uma corda. Apenas nesse instante o mago pode vislumbrar a fera: "La luz entra en la bóveda; en ese instante puedo ver al jaguar" (p.596). 
É possível identificar nas mitologias ameríndias que as etnias (principalmente sul-americanas) consideram os não humanos como sujeitos e protagonistas na comunidade (cf. DESCOLA, 2013). Os animais em especial são ex-humanos e ex-parentes que preservam sua vida social. O parentesco com os humanos se deve à sua semelhança de almas; não à toa as narrativas míticas e muitas narrativas literárias tratam os animais como 'gente-queixada', 'genteanta', 'gente-onça', com corpos diferentes, mas com a mesma alma. (VIVEIROS DE CASTRO, 1996). O jaguar, particularmente também conhecido como onça e tigre, é figura presente nas mitologias da maioria dos povos americanos, trata-se de um animal considerado mágico, sábio, forte e veloz. Lembremos que ele aparece em muitas narrativas míticas, como um ser que ensina o homem a caçar, a usar o fogo na preparação de alimentos e a cultivar determinadas espécies, como o milho. Em uma ou outra ocasião a vida dos povos envolvidos no aprendizado modifica-se de modo significativo.

O texto informa que o mago fora poderoso e realizava sacrifícios com facas, e que ainda lhe resta magia embora já tenha assumido posição de morte. $\mathrm{O}$ que se segue nos dá maiores pistas por meio de referências que podem ser históricas:

La víspera del incendio de la Pirámide, los hombres que bajaron de altos caballos me castigaron con metales ardientes para que revelara el lugar de un tesoro escondido. Abatieron, delante de mis ojos, el ídolo del dios, pero éste no me abandonó y me mantuve silencioso entre los tormentos. Me laceraron, me rompieron, me deformaron y luego desperté en esta cárcel, que ya no dejaré en mi vida mortal. (BORGES, 1994, p.596) 
Ao que tudo indica, e a leitura o permite, a narrativa referese ao momento histórico violento em que, durante o contato, os espanhóis torturaram os líderes religiosos para amealhar, primeiramente, informações e segredos dos povos, e sem seguida, ouro.

Aparentado com outro personagem borgeano, Funes, o mago passa dias e noites exercitando a memória de tudo que já vivera. Dela advém a motivação da denominação do conto e a esperança do encarcerado:

Una noche sentí que me acercaba a un recuerdo preciso; antes de ver el mar, el viajero siente una agitación en la sangre. Horas después, empecé a avistar el recuerdo; era una de las tradiciones del dios. Éste, previendo que en el fin de los tempos ocurrirían muchas desventuras y ruinas, escribió el primer día de la Creación una sentencia mágica, apta para conjurar esos males. (...) Consideré que estábamos, como siempre, en el fin de los tiempos y que mi destino de último sacerdote del dios me daría acceso al privilegio de intuir esa escritura. (BORGES, 1994, p.596-597)

A referência remonta aos signos inscritos no universo e que aguarda um leitor capaz de decifrá-los, possivelmente uma alma exercitada nas artes dos mistérios, provavelmente um sacerdote como nossa personagem, um hermeneuta místico que acredita em um deus que, prevenido, escrevera já, no início dos tempos, a sentença de salvação do mundo.

O que será necessário a um tal desvendamento? Que faculdades humanas podem dar conta do conhecimento das coisas divinas? A que elemento do espírito pode um devoto recorrer para tamanha 
operação? O personagem borgeano une vertigem, intuição e lógica, é o que se pode depreender do trecho abaixo:

Esta reflexión me animó y luego me infundió una especie de vértigo. En el ámbito de la tierra hay formas antiguas, formas incorruptibles y eternas; cualquiera de ellas podía ser el símbolo buscado. Una montaña podía ser la palabra del dios, o un río o el imperio o la configuración de los astros. Pero en el curso de los siglos las montañas se allanan y el camino de un río suele desviarse y los imperios conocen mutaciones y estragos y la figura de los astros varía. En el firmamento hay mudanza. La montaña y la estrella son individuos y los individuos caducan. Busqué algo más tenaz, más vulnerable. Pensé en las generaciones de los cereales, de los pastos, de los pájaros, de los hombres. Quizá en mi cara estuviera escrita la magia, quizá yo mismo fuera el fin de mi busca. En ese afán estaba cuando recordé que el jaguar era uno de los atributos del dios. (BORGES, 1994, p.597)

A sentença terá sido escrita com caracteres naturais, minerais, vegetais, animais? Com letras sociais, como o Império? Com fogo, com água? Na própria face ou na face do outro? A suspeita maior recai sobre o jaguar, afinal, a fera é um dos atributos do deus a que o mago é fiel:

Entonces mi alma se llenó de piedad. Imaginé la primera mañana del tiempo, imaginé a mi dios confiando el mensaje a la piel viva de los jaguares, que se amarían y se engendrarían sin fin, em cavernas, en cañaverales, en islas, para que los últimos hombres lo recibieran. Imaginé esa red de tigres, ese caliente laberinto de tigres, dando horror a los prados y a los rebaños para conservar un dibujo. En la otra celda había un jaguar; en su 
vecindad percibí una confirmación de mi conjetura y un secreto favor. (BORGES, 1994, p.597)

É possível que a espécie dos jaguares teria sido a responsável por carregar a fórmula divina e todo poderosa. O que Tzinácan não menciona é que segundo o povo quiche (e outros povos), além do jaguar ser animal sagrado, os sacerdotes, magos, xamãs ou pajés nele se transformam.

Apenas ao meio-dia, e por um momento, o mago pode contemplar o jaguar, seu vizinho, e percebe a variedade na composição e disposição das manchas que desenham a pele do animal. Diante de enigma sem igual, o personagem conjectura acerca de questões da ordem da interpretação, sabe que o que busca remete a tudo que há:

Qué tipo de sentencia (me pregunté) construirá una mente absoluta? Consideré que aun en los lenguajes humanos no hay proposición que no implique el universo entero; decir el tigre es decir los tigres que lo engendraron, los ciervos y tortugas que devoró, el pasto de que se alimentaron los ciervos, la tierra que fue madre del pasto, el cielo que dio luz a la tierra. Consideré que en el lenguaje de un dios toda la palavra enunciaría esa infinita concatenación de los hechos, y no de un modo implícito, sino explícito, y no de un modo progresivo, sino inmediato. (BORGES, 1994, p.597-598)

Suas reflexões atingem as questões linguísticas e epistemológicas subsumidas em todo ato de interpretação, mas seria questão mesmo de interpretação? Ou trata-se de um tipo de compreensão privilegiada? Mas toda a lucidez racional do mago, sua dedicação especulativa e crítica, seu desempenho nos exercícios espirituais não serão suficientes para o êxito de seu objetivo. 
Será preciso a intervenção de algo que seja aparentemente exterior ao controle pela mente ou pelos sentidos: o texto, assim, demonstra que o sonho rompe o primeiro véu do real. O personagem sonha que está sendo soterrado por milhares de grãos de areia, no interior do sonho lembra-se que está sonhando e acorda, livrandose do pesadelo agradece pelo cárcere. A revelação ao que parece, Ihe vem na vigília:

Entonces ocurrió lo que no puedo olvidar ni comunicar. Ocurrió la unión con la divinidad, con el universo (no sé si estas palabras difieren). El éxtasis no repite sus símbolos; hay quien ha visto a Dios en un resplandor, hay quien lo ha percibido en una espada o en los círculos de una rosa. Yo vi una Rueda altísima, que no estaba delante de mis ojos, ni detrás, ni a los lados, sino en todas partes, a un tiempo. Esa Rueda estaba hecha de agua, pero también de fuego, y era (aunque se veía el borde) infinita. Entretejidas, la formaban todas las cosas que serán, que son y que fueron, y yo era una de las hebras de esa trama total, y Pedro de Alvarado, que me dio tormento, era otra. Ahí estaban las causas y los efectos y me bastaba ver esa Rueda para entenderlo todo, sin fin. (BORGES, 1994, p.598-599)

Podemos delegar à imaginação o que a mente e linguagem não são capazes de acessar? Sergio Medeiros sugere que a roda vislumbrada e sentida pelo mago pode ser uma alusão aos ciclos temporais da cosmologia maia (BROTHERSTON; MEDEIROS, 2007, p.475). Em outra referência, desta vez feita por Federico Navarete em obra organizada por Alejandro Ortiz Rescaniere, em outros textos fundamentais para o conhecimento da américa pré-hispãnica, Los libros de Chilam Balam dos maias de Yucatán, encontramos uma menção a "rueda de los katunes". Segundo o pesquisador: 
Los Libros de Chilam Balam están organizados por katunes y combinan descripciones históricas y míticas de los katunes anteriores con profecías sobre los katunes futuros. En la práctica muchas vezes es muy difícil distinguir unas de otras, pues era frecuente que los autores de estos libros hablaran del passado en tiempo futuro y de futuro en tiempo passado, pues en un sistema cíclico como el de la "rueda de los katunes" el futuro quedaba de alguna manera en el pasado e vice-versa. (Farris, 1985). (RESCANIERE, 2006, p.116)

Ciclicamente, o sacerdote voltava a exercer plenamente seu destino de sacerdote do deus e acessava finalmente o conhecimento absoluto? Como possuidor dos mistérios e desejos divinos, o mago volta a viver os momentos em que, pleno de poder e fé, costumava abrir o peito de suas vítimas com uma faca?

Na sequência da narrativa de Borges, ainda que o texto explicitamente se refira ao "entendimento", antes, a linguagem sugere enovelamento místico, experiência com o maravilhoso, êxtase que promove a revelação, relação íntima com o sagrado. Vejamos como se dá a construção textual:

"iOh dicha de entender, mayor que la de imaginar o la de sentir! Vi el universo y vi los íntimos designios del universo. Vi los orígenes que narra el Libro del Común. [...]. Vi infinitos procesos que formaban una sola felicidad $y$, entendiéndolo todo, alcance también a entender la escritura del tigre". (BORGES, 1994, p.599).

Como explicam as artes da cabala, a linguagem divina compartilhará seus poderes com aquele que a alcançar. Cabalistas dedicam a vida a buscar a palavra secreta através de formulas que 
aplicam às letras da Torah, por meio do êxtase ou pela rigorosa rotina de orações e jejum. No caso de nossa personagem, o poder a ser adquirido diz respeito principalmente ao controle do tempo, elemento determinante na cultura de Tzinácan. O mago assim explica: "Es una fórmula de catorce palabras casuales (que parecen casuales) y me bastaría decirla en voz alta para ser todopoderoso. [...] Pero yo sé que nunca diré esas palabras, porque ya no me acuerdo de Tzinacán (BORGES, 1994, p.599 - grifo nosso) O tempo subvertido, direcionado ao momento anterior à chegada dos espanhóis. Alvarado, o destruidor, destroçado pelo jaguar; o cárcere abolido, a posse da imortalidade, a reconstrução do império Maia, e o controle das terras de Montezuma. Estranho milagre de síntese, 14 palavras, número a que vários textos borgeanos se referem como número do infinito, que, uma vez pronunciadas, irradiam todo o poder (BORGES, 1994, p.599).

O final da citação acima, entretanto, é acachapante: o mago declara que nunca dirá as 14 palavras porque já não se lembra de si mesmo. Já não se lembra quem é Tzinácan. Trata-se de um final que dobra o êxito da descoberta, ou, em outras palavras, o resultado lógico da situação predomina sobre poder advindo da experiência do mago com o maravilhoso: "Que muera conmigo el misterio que está escrito en los tigres. Quien ha entrevisto el universo, quien ha entrevisto los ardientes designios del universo, no puede pensar en un hombre, en sus triviales dichas o desventuras, aunque ese hombre sea él" (BORGES, 1994, p.599). Afinal, quem conhece a linguagem divina e o próprio deus, tem seu ego abolido, sabe-se pouco significativo na roda inesgotável dos tempos. A decepção do leitor vem com o entendimento 
racional da coerência decorrente da experiência maravilhosa, compreensão que estipula a não ação.

Em outro sentido, contrariamente à coerência, o mago estaria a demonstrar passividade e, ao invés de adotar uma postura política contra o colonizador, fazendo uso da sentença mágica, vive uma reconciliação dos contrários a partir do êxtase experimentado. (BROTHERSTON; MEDEIROS, 2007, p.477). Dificilmente seríamos capazes de avaliar o resultado da experiência com a ordem divina, o êxtase com o maravilhoso, fato é que o mago decide não usar o poder que lhe advém da vivência, o que possibilitaria reconstruir a pirâmide e o império, e varrer a figura e o nome de Pedro Alvarado, de em todos os tempos.

Importante pensar como o elemento indígena americano e a cultura literária escrita, fator externo às sociedades nativas, se encontram a partir do momento da invasão. A destruição da cultura nativa não implica totalmente o seu esquecimento, a tradição oral e os textos escritos pelos indígenas o provam, e também, textos que são, de algum modo, devedores e desdobramentos do agressivo encontro. Segundo Rescaniere:

La tradición oral americana - la visión mítica de la vida, los temas y obsesiones que transmitem sus relatos - tiene um influjo no sólo en los pueblos de tradición ameríndia. En las sociedades nacionales - en especial aquellas donde la presencia o el substrato indígena son importantes - se puede advertir las huellas o la presencia de esa tradición. En la ciudad populosa latino-americana, en su literatura culta, perviven algunas de las concepciones expressadas en los viejos mitos: una visión catastrófica del futuro y un privilegiar el 
presente, una fascinación por el outro, un cuerpo múltiple y, por lo mismo, frágil. Los mitos dejan entrever el alma de los pueblos que los cuentan; no son historias sin sentido; al contrario, dan sentido a la vida. (2006, p.31)

De acordo com nossa leitura, o mago-jaguar, retirado do envoltório de sua cultura, transforma-se, como o personagem do conto anteriormente lido, em personagem excepcional, maravilhosa ou extraordinária. Como ocorre na história de Asterión, La escritura del Dios permite identificar o mito sob o gênero literário. O personagem mítico, então, é empurrado ao subterrâneo da cultura para que o fictício mago ganhe vida. Se há, na literatura de todos os tempos, textos que salvam o futuro da humanidade com sua significação auspiciosa, há também aqueles que testemunham criticamente o apagamento e a morte de culturas inteiras. O legado maravilhoso traz em seu rastro histórico uma andança letal em terras sul americanas. Por outro lado, as ruínas dos seres primeiros sob o palimpsesto da narrativa dos novos personagens, rebatizados pela ficção, demonstram que a ficção, contraditoriamente, também trabalha para a sobrevivência de saberes, culturas e artes que correm o risco do mais amplo esquecimento. Talvez um texto ficcional salve a memória e a identidade.

\section{REFERÊNCIAS}

BORGES, Jorge Luis (1994). "La casa de Asterión". In: Obras completas: 1923-1949. Buenos Aires: Emecé Editores, p.569-570. (1994). "La escritura del Dios". In: Obras completas: 19231949. Buenos Aires: Emecé Editores, p.596-599.

BROTHERSTON, Gordon; MEDEIROS, Sérgio (Orgs.) (2007). Popol Vuh. São Paulo: Iluminuras. 
CAMPRA, Rosalba (2016). Territórios da ficção fantástica. Flávio Pestana (Trad.). Rio de Janeiro: Dialogarts.

DESCOLA, Philippe (2015). "Além de natureza e cultura". Tessituras, Pelotas, 3(1), 7-33, jan./jun.

MEDEIROS, Sérgio (2007). “Um olhar, uma sentença”. In: BROTHERSTON, Gordon; MEDEIROS, Sérgio (Orgs.). Popol Vuh. São Paulo: Iluminuras, p.471-478. NARAVERRETE, Federico (2006). "Mitología maya". In: Mitologías Amerindias. Madrid: Editorial Trotta, p.103-128. (Enciclopedia Iberoamericana de Religiones, 05)

PADURA, Leonardo (1989). Lo real maravilloso: creación y realidad. La Habana: Editorial Letras Cubanas.

RALEIGH, Walter (2017). A descoberta do grande, belo e rico império da Guiana. Hélio Rocha (Trad.). São Carlos: Editora Scienza.

RESCANIERE, Alejandro Ortiz (edición) (2006). "Introducción". In: Mitologías Amerindias. Madrid: Editorial Trotta. (Enciclopedia Iberoamericana de Religiones, 05)

SIMÕES, Maria João (2018). "Personagem irreal: estratégias da figuração disforme ou informe". In: GARCÍA, Flavio et al. A personagem nos mundos possíveis do insólito ficcional. Rio de Janeiro: Dialogarts, p.53-69.

SPERBER, Suzi Frankl (2011). "Introdução. A lenda da flor azul, o mito e o conto de fadas". In: VOLOBUEF, Karin (Org.). Mito e magia. São Paulo: Editora Unesp.

VIVEIROS DE CASTRO, Eduardo Viveiros de (2002). A inconstância da alma selvagem - e outros ensaios de antropologia. São Paulo: Cosac Naify.

(1996). "Os pronomes cosmológicos e o perspectivismo ameríndio". Rio de Janeiro: Mana. 2(2), p.115-144, out. 


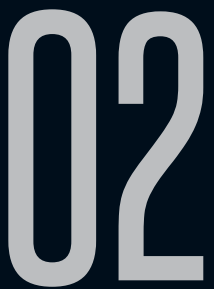

\section{O EXTRATERRESTRE: ESSE SER MARAVILHOSO DE TODOS OS TEMPOS}

Luma Maria Braga de Urzedo (UFU) Marisa Martins Gama-Khalil (UFU)

Recebido em 07 dez 2018. Luma Maria Braga de Urzedo é Graduada em Letras Aprovado em 13 fev 2019. Português e Literaturas de Língua Portuguesa pela UFU e Mestranda em Estudos Literários pelo PPGLET - UFU. É Bolsista CAPES e tem como produção mais relevante o artigo intitulado Ficção científica: os maravilhosos E.T.s na literatura latino-americana publicado no livro No território de Mirabilia: estudos sobre o maravilhoso na ficção. É membro do Grupo de Pesquisas em Espacialidades Artísticas (GPEA/ CNPq) e possui interesse nas áreas de Literatura Fantástica e Ficção Científica. Lattes: http://lattes.cnpq. br/3742775719026794. E-mail: lumam.braga@gmail.com

Marisa Martins Gama-Khalil é Doutora em Estudos Literários pela UNESP e Pós-Doutora pela Universidade de Coimbra. É professora da UFU e pesquisadora Produtividade em Pesquisa pelo CNPq. Atua no Programa de Pós-Graduação em Estudos Literários e no PROFLETRAS da UFU. Tem publicações na área da Literatura Fantástica, incluindo ensaios e organização de livros, como Nos labirintos do medo: estudos sobre o medo na ficção; No território de Mirabilia: estudos sobre o maravilhoso na ficção; As literaturas infantil e juvenil ... ainda uma vez. É líder do Grupo de Pesquisas em Espacialidades Artísticas (GPEA/CNPq), atuando nos campos da literatura fantástica, da narratologia 
e do letramento literário. Lattes: http://lattes.cnpq. br/9430138689219946. E-mail: mmgama@gmail.com

Resumo: Personagem maravilhosa recorrente na literatura contemporânea é o extraterrestre; contudo sua irrupção nas obras literárias é muito antiga, remontando o início da era cristã, com Luciano de Samósata. Para tratarmos da configuração do extraterrestre na literatura como um ser maravilhoso de todos os tempos, analisaremos duas obras especialmente, o romance de H. G. Wells A guerra dos mundos e o conto "História da sua vida" de Ted Chiang, ainda que outras obras sejam trazidas ao ensaio, iluminando a representação literária do E.T., como Micrômegas de Voltaire e Uma história verídica de Luciano de Samósata.

Palavras-chave: Literatura fantástica; Ficção científica; Extraterrestre.

Abstract: The extraterrestrial is a recurring marvelous character in contemporary literature; although its irruption in the literary works is very old, related to the beginning of the Christian era, with Lucian of Samosata. To deal with the configuration of the extraterrestrial in literature as a marvelous being of all time, we will analyse two works especially, H.G. Wells's novel The War of the worlds and Ted Chiang's short story, "Story of your life", although other works are brought to the essay, illuminating E.T. literary representation, as Micromegas by Voltaire and A true story of Lucian by Samosata.

Keywords: Fantastic literature; Science fiction; Extraterrestrial.

Diversas são as definições de ficção científica. Algumas possuem um caráter bastante restritivo e a conceituam como um gênero que deve projetar, promover e extrapolar a ciência; outras buscam abranger o máximo de obras possíveis e defendem que a 
ficção científica é mais uma vertente do fantástico. Acreditamos que a ficção científica pode contemplar várias obras que em uma leitura superficial parecem não dialogar. Se projetarmos nosso foco sobre os alienígenas, por exemplo, encontraremos histórias que vão compor facetas discrepantes entre esses seres. Pensemos em dois clássicos do cinema do final dos anos 1970 e início dos anos 1980, Alien': o oitavo passageiro (1979), de Ridley Scott, e E.T. O extraterrestre (1982), de Steven Spielberg.

Ao consultar o site http:imdb.com (Internet Movie Database), que se configura como uma base de dados sobre cinema e séries online, verificamos como os usuários desse site classificam esses filmes de acordo com os gêneros. Alien é definido como horror/scifi, enquanto E.T. é considerado family/sci-fi. O primeiro se passa no espaço em um clima claustrofóbico de perseguição, já o segundo ambienta-se em uma casa cheia de crianças que escondem um ser alienígena amigável dos adultos. Percebemos a partir desses dois exemplos que a ficção científica não se fecha quanto aos seus temas e abordagens, muito menos se engessa em si mesma, mas sim comporta um hibridismo ao se relacionar com outros gêneros, permitindo que um mesmo ser insólito possa aparecer das mais diferentes formas, e, no caso do alienígena, existem muitas possibilidades. Contudo, a maior recorrência na apresentação do alienígena, como nos filmes supracitados, ocorre por meio de dois polos: os alienígenas do bem, aqueles que querem nos ensinar ou apenas estar conosco, e os alienígenas do mal, que buscam tomar ou destruir nosso planeta ou, ainda, que não são receptivos à chegada de terráqueos no espaço.

1 https://www.imdb.com/find?ref_=nv_sr_fn\&q=alien\&s=all 
Além da grande frequência desses tipos antagônicos de extraterrestres existem ainda alguns que possuem uma presença menos maniqueísta, como aquele do filme $O$ dia em que a terra parou (1951), cuja chegada tem a ver com um ultimato (mudem ou morram) e apresenta-nos um ser alienígena que acaba se envolvendo com as mazelas humanas. Contudo, independentemente de suas motivações, os seres extraterrestres são por si só bastante enigmáticos, tanto que fazem parte das nossas narrativas há muito tempo e, ainda hoje, geram inúmeros frutos ficcionais.

O alienígena representa o outro no sentido mais extremo possível: não compartilha de nossa cultura, não possui a mesma composição biológica que a nossa e vem de um lugar longínquo, desconhecido e inexplorado. Além disso, o alienígena ocupa uma posição bastante ambígua entre a crença e a imaginação, como lembra Donald R. Burleson, em seu tópico sobre alienígenas, presente em Icons of horror and the supernatural: an encyclopedia of our worst nightmares:

O ícone alienígena na literatura e no filme difere, em seu impacto sobre a psique humana, de outros ícones do horror e do sobrenatural como o vampiro, o lobisomem, o carniçal e o zumbi. Praticamente ninguém afirma ter tido qualquer experiência, indireta ou não, com vampiros ou zumbis, mas muitas pessoas (mesmo que não tenham tido essas experiências diretamente) pelo menos têm um amigo ou um parente que afirma ter visto algo realmente anômalo nos céus.

Assim, o ícone alienígena é aquele que, pelo menos por boato, desfrutou de alguma exposição na experiência humana, ao contrário, digamos, dos 
lobisomens. Se um alienígena é uma entidade que a tia Claire ou o dentista pode ter visto, ou cuja nave espacial, de qualquer modo, essas pessoas possam ter vislumbrado, então o alienígena entra no reino crepuscular do talvez fictício, talvez não inteiramente fictício. É essa ambiguidade, essa dificuldade na categorização, em parte, que empresta ao ícone seu interesse pelos leitores e pelos patrocinadores do cinema. (BURLESON, 2007, p.2 - tradução nossa) ${ }^{2}$

É necessário contemporizarmos a posição de Burleson, porque sua perspectiva é de um sujeito cuja cultura é estadunidense, onde não se tem com frequência manifestações de contatos com lobisomens, mas sim com alienígenas. Todavia, não se pode dizer o mesmo de algumas localidades brasileiras, nas quais há pessoas que revelam uma suposta experiência com lobisomens. Trata-se, portanto, de uma questão de ordem regional e cultural. Entendemos que o lobisomem (assim como o boto também, por exemplo) vinculase àquilo que Carpentier (2009) denominou real maravilhoso, que é caracterizado como uma manifestação do maravilhoso vinculada à realidade de uma cultura específica e por esse motivo associase a uma crença. No caso do alienígena, compreendemos que a 2 [...] the alien icon in literature and film differs, in its impact upon the human psyche, from such other icons of horror and the supernatural as the vampire, the werewolf, the ghoul, and the zombie. Practically no one claims to have had any experience, indirect or otherwise, with vampires or zombies, but many people (even if they have not had such experiences themselves directly) at least have a friend or a relative who claims to have seen something truly anomalous in the skies.

Thus the alien icon isone that, at least by rumor, has enjoyed some exposure in human experience, unlike, say, werewolves. If an alien is an entity that one's Aunt Clara or one's dentist may conceivably have seen, or whose spacecraft at any rate such people may have glimpsed, then the alien enters that twilight realm of the perhaps fictitious, perhaps not entirely fictitious being. It is this ambiguity, this dificulty in categorizability, in part, that lends the icon its interest for readers and for patrons of film. . (Icons of horror and the supernatural: an encyclopedia of our worst nightmares/edited by S.T. Joshi./The Alien: Donald R. Burleson, 2007, p.2) 
abrangência da suposta experiência (contato) é mais universal, uma vez que há relatos de encontros com alienígenas em todas as partes do mundo.

Por ser esse ser de tamanha complexidade e universalidade, o extraterrestre funciona como um novum, que nos confunde e nos instiga. A partir da explicação dada por Adam Roberts (2018) acerca do conceito de novum de Darko Suvin, é possível compreender melhor como o extraterrestre se configura como um ser ficcional tão caro à ficção científica:

dispositivo, artefato ou premissa ficcionais que põem em foco a diferença entre o mundo que o leitor habita e o mundo ficcional do texto de FC. Um novum pode ser algo material, como uma espaçonave, uma máquina do tempo ou um dispositivo de comunicação mais-rápido-que-a-luz; ou pode ser algo conceitual, como uma nova versão de gênero ou consciência. (ROBERTS, 2018, p.37)

O alienígena funciona como novum na medida em que nos retira de nosso mundo empírico e nos transporta para o outro metaempírico. Optamos pelo termo metaempírico ao invés de sobrenatural, pois, como Filipe Furtado explica em sua definição de modo fantástico presente no e-dicionário de termos literários:

Diversas razões apontam as vantagens operativas do conceito de metaempírico face ao de sobrenatural na abordagem do modo fantástico. Desde logo, o primeiro abrange uma gama bastante mais ampla de figuras e situações. Depois, permite inferir o teor relativo e contingente das noções que qualifica e da forma como estas têm sido encaradas através da história, assim evidenciando a sua estreita dependência da 
sucessão de factores sociais e culturais. Por outro lado, embora a expressão deixe depreender que, pelo menos na sua grande maioria, essas manifestações são indetectáveis e incognoscíveis, não exclui necessariamente a hipótese de algumas delas virem a tornar-se objecto de conhecimento em épocas subsequentes. Daí que muitas personagens e acontecimentos insólitos correntes em narrativas de ficção científica (alienígenas, mundos paralelos, viagens interestelares ou no tempo, etc.), situando-se embora para lá do âmbito mais restrito do sobrenatural, sejam, com este, inteiramente englobáveis no conceito mais lato de metaempírico. Portanto, as narrativas de quase todos os tempos em que elementos a ele circunscritos assumem uma função central no desenvolvimento da intriga constituem (desde a epopeia de Gilgamesh às modernas histórias fantásticas) o que se poderá denominar "ficção do metaempírico", afinal outra designação possível do modo fantástico. (FURTADO, 2018)

Compreender a ficção científica como uma ficção do metaempírico abrange o seu âmbito racionalizante, pois, diferente das fadas, vampiros ou duendes, há um aspecto cognitivo que envolve a aparição do E.T., quer dizer, no caso desse ser metaempírico existem discursos científicos que circunscrevem a possibilidade de sua existência, como o discurso da ufologia e o da cosmologia. Não existem provas concretas da existência de E.T.s, mas existem métodos e estudiosos que investigam essa possibilidade, o que já é suficiente para que ficcionistas criem. Para Suvin (1988), a ficção científica é:

Um gênero literário ou construto verbal cujas condições necessárias e suficientes são a presença 
e interação de distanciamento e cognição, e cujo dispositivo principal é uma moldura imaginativa alternativa ao ambiente empírico do autor. (1988, p.37)

Além disso, o alienígena corresponde a um novum diferente do robô, outra figura muito famosa nas histórias de ficção científica. Diferem-se especialmente pelo caráter projetivo do robô já dotado de inteligência artificial (os robôs já existem em nosso cotidiano, mas ainda não chegaram ao patamar que a ficção científica descreve, de seres autônomos e inteligentes), eles talvez possam existir, mas os alienígenas talvez já existam. Esses robôs aparecem exclusivamente em narrativas futuristas, enquanto os alienígenas podem aparecer em narrativas de qualquer temporalidade, sendo um perigo iminente. Acreditamos que, nesse sentido, o extraterrestre corresponde a um dos grandes ícones da ficção científica, tendo grande influência na consolidação do gênero no gosto popular.

O cinema, o rádio ${ }^{3}$, as séries, as revistas em quadrinhos e os documentários "talvez verdadeiros/talvez fictícios", deram uma especial projeção ao extraterrestre a partir do século $X X$, entretanto a obra que irá funcionar como um marco para as histórias de extraterrestres foi escrita um pouco antes desse "boom" da ficção científica, surge no século XIX, mais precisamente em 1898, o famoso romance de H.G. Wells: A guerra dos mundos.

Em A guerra dos mundos, o embate com o alienígena é levado ao extremo. Até então havia uma predominância da imagem do alienígena amigo, observador, como em Micrômegas (1732),

3 Lembremo-nos da leitura dramatizada do cineasta Orson Welles de A guerra dos mundos, em 1938, às vésperas do Halloween, em uma rádio estadunidense, desencadeadora de pânico na população que acreditou que aquela era, na verdade, uma transmissão ao vivo da chegada de naves espaciais em nosso planeta. 
de Voltaire, ou como um conhecido exótico em uma voyage extraordinaire, como em Uma história verídica, de Luciano de Samósata (II.d.C). O romance de Wells irá influenciar e inspirar na criação de diversas obras sobre invasões alienígenas, como lembra Brian Aldiss no prefácio de A guerra dos mundos (2016, p.30):

É a pedra fundamental de todas as histórias sobre invasões alienígenas impressas ou filmadas. Seguindo o exemplo de Wells, surgiram muitas outras histórias em que o mundo, ou pelo menos a Inglaterra, é devastado. Entre elas estão $A$ nuvem da morte, de Conan Doyle, The Day of the Triffids [O dia das trifides], de John Wyndham, The Death of Grass [A morte do pasto], de John Christopher, The Wind from Nowhere [O vento de lugar nenhum], de J.G.Ballard, $O$ macaco e a essência, de Aldous Huxler, e Herdeiros da Terra, de minha autoria.

Wells cria um novo paradigma para as histórias com seres extraterrestres ao descrever a chegada de marcianos prontos para invadir nosso planeta. Nas quase 300 páginas do romance, temos um narrador que descreve detalhadamente a mudança de sua rotina depois da queda de cilindros repletos de marcianos e tecnologia marciana de guerra. Por essa breve sinopse é possível que o leitor se questione se essa não é só mais uma narrativa de guerra, repleta de clichês, mais um produto da literatura de massa. Infelizmente, é comum o julgamento anterior à leitura dos textos de ficção científica.

Devido a uma dificuldade de distinguir ciência e tecnologia ${ }^{4}$ por parte da crítica e dos leitores, promove-se uma generalização 4 Comumente acredita-se que a tecnologia é derivada da ciência (e nesse sentido acabase excluindo muitas ficções científicas que não se relacionam com as ciências exatas ou artefatos tecnológicos), mas como bem lembra Adam Roberts "(...) a ciência se torna uma moldura filosófica idealista (...) A tecnologia, por outro lado, é o discurso de ferramentas e máquinas, sendo as ferramentas extensões do trabalhador humano [...] e as máquinas, dispositivos que se mantêm a parte do trabalhador humano" (2018, p.49). 
dos textos de ficção científica que resulta em dois preconceitos. O primeiro é o preconceito corrente nos meios acadêmicos e do público dito intelectual pela crença de que a ficção cientifica trata apenas de questões tecnológicas, abandonando questões existenciais e legando ao esquecimento a composição estética. O segundo é o preconceito interior ao gênero, em função de fãs e escritores enxergarem a ficção científica sob essa única perspectiva, considerando as obras não tecnológicas menores ou pseudocientíficas.

Em A guerra dos mundos temos tanto os discursos científicos, mais conceituais, quanto os discursos das máquinas, girando em torno de uma discussão essencialmente humana. Nesse sentindo a obra de Wells também representa um marco para o gênero, já que ela bifurca para ramos muito populares da ficção científica do século seguinte, o especulativo e social/reflexivo.

Seu sentido especulativo que reflete sobre a chegada de alienígenas, seu poderio e nossas possíveis formas de contraataque chamam atenção em uma leitura superficial da obra que acaba servindo como influência para muitas histórias de revistas pulp no século XX e para o cinema hollywoodiano do passado e da contemporaneidade. Esse sentido corresponde ao mais popular, mas ao mesmo tempo mais marginalizado nos meios intelectuais, isso porque Wells foi extremamente original no momento em que escreveu essa obra, que não se tratava meramente de uma discussão especulativa. Contudo, seu modelo foi repetido de forma superficial inúmeras vezes, até se tornar um clichê dentro do gênero. Esse modelo ignora o pessimismo que perpassa a guerra de Wells, dando lugar a histórias nacionalistas 
(especialmente estadunidenses) de bravos soldados humanos que combatem de igual para igual seres alienígenas, como é o caso do filme Independence Day (1996).

A nós interessa principalmente sua segunda contribuição, no aspecto social/reflexivo da ficção científica, especialmente aquela com seres extraterrestres. O narrador de $A$ guerra dos mundos ressalta desde o início a postura de indiferença e soberba do homem, que ignorava a possibilidade de vida em outros planetas até a chegada dos marcianos naquele dia fatídico.

No primeiro momento da narrativa apenas um cilindro foi lançado à Terra e um pequeno grupo de curiosos, que incluía o narrador do romance, cerca esse objeto, até que ele se abre, revelando um alienígena com armamento ultra-avançado que extermina todos ao seu redor. O narrador escapa por sorte e a partir daí parte desesperado, pronto para fugir, mas depara com uma cidade que permanece indiferente aos eventos por ele vividos; os jornais que pouco noticiam sobre a chegada e a população subestima a capacidade destrutiva dos marcianos, já que aquele parecia não conseguir se movimentar com agilidade no planeta Terra. Mais tarde descobre-se que esses seres extraterrenos trouxeram consigo máquinas gigantescas capazes de transportá-los, protegêlos e ainda atacar os humanos com armas de desintegração e calor.

A derrocada humana se dá a partir daí. Os marcianos chegaram com o único objetivo de tomar a Terra para si e essa atitude pode parecer assustadora e maldosa, mas o narrador nos lembra de que nós, humanos, fizemos isso inúmeras vezes em nossa história: 
própria espécie impôs não só a animais, como os extintos bisões e dodôs, mas a suas próprias raças menores. Os tasmanianos, apesar da aparência humana, foram inteiramente dizimados numa guerra de extermínio promovida por imigrantes europeus no espaço de cinquenta anos. Será que somos realmente apóstolos da tolerância para nos queixarmos, quando os marcianos nos combateram com a mesma mentalidade? (WELLS, 2016, p.47-48)

Povos que se consideravam superiores a outros sempre promoveram o extermínio em nosso planeta, foi assim em nossa América também. A Guerra dos mundos nos lembra disso e mostra que, talvez, os motivos dos marcianos fossem mais nobres do que aqueles que levaram nossos ancestrais à exploração de outras terras. Na história, o planeta Marte resfriou e seus habitantes precisavam encontrar um novo local para manter sua espécie viva, a Terra foi escolhida porque era o local mais próximo.

É possível perceber que Wells enxergava o processo de degradação do planeta como natural, visto que em sua história considera que Marte está ruindo por ser um planeta mais antigo que o nosso e não por ter tido seus recursos mais explorados. É normal que discussões acerca do meio ambiente não fossem proeminentes no final do século XIX, momento em que a industrialização começava a ganhar força, mas se lido hoje o romance de Wells pode nos fazer refletir muito acerca de tais questões. Esses marcianos não poderiam representar a nós mesmos daqui a alguns séculos, procurando por um novo lar, quando um possível colapso ambiental do planeta ocorrer?

Como dito, a obra constantemente evidencia uma postura egocêntrica e arrogante da humanidade, que inicialmente subestima 
a chegada dos marcianos e só após se ver imersa no caos percebe que não passa de mais uma dentre todas as espécies do planeta que pode perder espaço, como todas as outras. O alienígena vem à Terra para tomar o topo da cadeia alimentar dos humanos e seus hábitos alimentares são vistos mais uma vez com horror, porém esse horror novamente é relativizado:

Não consigo forçar-me a descrever o que não suportava sequer assistir. Digamos apenas que o sangue obtido de um animal ainda vivo, na maioria dos casos um ser humano, era transferido diretamente, por meio de uma pipeta, no canal receptor.

Por mais que essa ideia seja terrivelmente repulsiva para nós, devemos ter em mente como nossos hábitos carnívoros pareceriam repugnantes a um coelho inteligente. (WELLS, 2016, p.220)

A monstruosidade do alienígena para a humanidade é a mesma que os animais de nosso planeta possivelmente apontariam em nós se pudessem se expressar verbalmente. A indiferença dos marcianos é a mesma que a nossa: "Mas a máquina marciana não deu mais importância às pessoas, que corriam de um lado para outro, do que um homem daria depois de chutar um formigueiro, ao desespero das formigas" (WELLS, 2016, p.135). Os marcianos servem como espelho do domínio desenfreado e do egoísmo humano.

O antagonismo preconizado no título ironiza a relação que se tornará de submissão, pois os humanos mostram-se incapazes de travar uma guerra contra os marcianos e passam apenas a fugir, a guerra acontece, de fato, no mundo microscópico, são as pequenas bactérias terrestres que conseguem vencer ao final: 
Mas não há bactérias em Marte e, assim que os invasores chegaram, assim que começaram a beber e a comer, nossos microscópicos aliados começaram a preparar sua queda. Enquanto eu os observava, eles já estavam irremediavelmente condenados, morrendo e apodrecendo mesmo enquanto se moviam de um lugar para o outro. Era inevitável. (WELLS, 2016, p.283)

Os marcianos eram superiores aos humanos em tudo, exceto em sua capacidade de adaptação às adversidades microscópicas da Terra, e por isso sucumbiram ao final da narrativa. A guerra se mostrou injusta tanto para os humanos, que estavam muito atrasados em relação à tecnologia alienígena, quanto para os marcianos, que enfrentavam, na verdade, adversários invisíveis.

Questões relativas ao controle, à arrogância e à impotência perpassam toda a obra sutilmente, fazendo com que o extraterrestre assuma, então, feições bastante complexas, para além daquela já descrita por nós anteriormente. É nesse sentido que o aspecto social/reflexivo tem maior impacto do que o especulativo. Esses aspectos da obra serão essenciais para se pensar no lugar da ficção científica entre os outros estilos de narrativas de maior prestígio no campo literário. A obra de Wells, ao discutir o humano e não apenas deslumbrar os mais aficionados em tecnologias e geringonças futuristas, serve de inspiração para grandes autores e mostra, ainda, que a generalização e o preconceito pelos textos de ficção científica são infundados.

Mary Shelley, em Frankenstein, discute sobre a possibilidade criadora da ciência, se em algum momento seria possível que o homem se igualasse a Deus, enquanto Wells reflete sobre 
a capacidade destrutiva do desenvolvimento tecnológico, ao estabelecer constantes comparações entre os marcianos, maléficos e invasores, com as ações cotidianas do ser humano. Ambos criaram paradigmas do que a ficção científica viria a ser e seus olhares pessimistas contribuíram expressivamente para que a discussão acerca da sociedade e a reflexão sobre as ações humanas estivessem no cerne do gênero.

Omonstro de Dr. Frankenstein serve de inspiração especialmente para as histórias com robôs, androides e super-humanos que se voltam contra seus criadores, enquanto a imagem do E.T. que está pronto para nos exterminar motiva não apenas as obras com seres extraterrestres, mas também aquelas de futuros apocalípticos em que há a devastação de cidades e civilizações, seja por meio de epidemias, ataques de robôs ou problemas ambientais. Todas essas obras que colocam a impotência humana em jogo bebem, de certo modo, da fonte de Wells.

A obra de Wells, juntamente com a de Jules Verne e Mary Shelley, representa a vanguarda da ficção científica enquanto uma escritura sistematizada. Antes, muitas obras, em algum nível, discutiam temas e apresentavam personagens que se tornariam clássicos na ficção científica, mas ainda não tinham seu foco nesses seres e temas. Além disso, suas histórias com alienígenas serviram de inspiração na origem do cinema, o primeiro filme de ficção científica Le voyage dans la Lune (1902), que narra a história de astrônomos que viajam até a lua e são capturados por selenitas, é uma adaptação livre do romance de Wells Os primeiros homens da Lua (1901) e do de Verne Da terra à lua (1865). Dentre os vários temas da ficção científica, o primeiro a ser escolhido para ser filmado foi o dos extraterrestres. 
Esse intenso interesse pelos alienígenas, que levou a obra de Wells a conquistar tanto sucesso, a ser até mesmo adaptada para o cinema (que no início do século $X X$ mais parecia um dispositivo de ficção científica do que uma realidade imaginável), é mais antigo do que a própria Cosmologia. Costuma-se pensar que nosso olhar só se lançou para o espaço a partir das descobertas de Copérnico e Galileu, entretanto, mesmo quando acreditava-se que a Terra era o centro do universo, com base nas considerações de Aristóteles e Ptolomeu, que falavam sobre várias esferas, questões de elementos da natureza e elementos misteriosos, os extraterrestres já instigavam a imaginação de escritores. Um grande exemplo é a obra do escritor grego Luciano de Samósata, escrita no século II, intitulada Uma história verídica.

Na história de Luciano, ele e vários homens fazem uma expedição de navio e, levados por uma forte ventania, chegam à Lua que se encontra em guerra com o Sol. Ele e seus tripulantes ajudam a resolver essa briga e retornam ao planeta Terra, fazendo antes uma breve visita ao planeta Vênus que estava sendo colonizado. O narrador descreve os habitantes da lua, seres bizarros e com hábitos peculiares:

Antes de mais, o facto de eles não nascerem de mulheres, mas de seres machos. Na verdade, casam homens com homens, e não conhecem absolutamente nenhum nome de mulher. Até aos vinte e cinco anos, cada um casa fazendo de mulher, e dessa idade em diante faz de marido. E engravidam, não pelo ventre, mas pela barriga das pernas. [...]

Entre eles, é considerado belo quem é calvo ou desprovido completamente de cabelos, ao passo 
que detestam os cabeludos. [...] Além disso, os Selenitas têm barba, a qual cresce um pouco acima dos joelhos, mas não têm unhas nos pés, já que todos são monodáctilos. Acima das nádegas nasceIhes uma grande couve, como se fosse uma cauda, a qual está sempre viçosa e não se quebra se a pessoa cai de costas. [...]

No que respeita aos olhos, hesito em dizer como são, não vá alguém cuidar que minto, tal é o incrível da história. Apesar de tudo, porém, vou contar: têm olhos desenroscáveis, de modo que qualquer um pode tirar os seus e guardá-los, até voltar a precisar de ver; então coloca-os par ver. (s/d, p.37-39)

A descrição nada convencional de Luciano e seu estilo de escrita repleto de ironia são interpretados por Roberts (2018) como uma anti-ficção científica: "Seria mais exato considerar Luciano antes como anti-FC que como proto-FC; mas anti-FC envolve, ainda assim, um compromisso com os termos da FC." (2018, p.76). Acreditamos que a obra de Luciano deve ser pensada como uma das originárias da ficção científica, porque mesmo ironizando a ciência e as crenças de seu tempo, partiu delas para compor sua obra. E mesmo que a passagem pela Lua seja apenas uma das várias aventuras de sua personagem/ narrador (que é ele mesmo), sua obra é de grande importância por mostrar a nós, leitores contemporâneos, que os extraterrestres sempre perpassaram nossa imaginação, independentemente da concepção de Cosmo ou do conhecimento dele.

Sem dúvida de que quanto mais complexa se tornaram nossas ciências os extraterrestres passaram a assumir formas e motivações igualmente mais complexas. Em Uma história verídica os selenitas se parecem com os humanos, têm membros, tronco e cabeça, mas 
com muitas peculiaridades, como já mostramos, e seus modos se assemelham aos dos humanos, eles comem, bebem, dormem, se reproduzem e morrem, mas também de maneira mais bizarra.

A viagem de Luciano para a Lua não é uma viagem tão diferente de uma para um continente distante e inexplorado ou para uma ilha mítica, nela os alienígenas estão em pé de igualdade com outros seres maravilhosos, como árvores com forma feminina que agarram homens na floresta ou pessoas que vivem há anos no estômago de uma baleia. Isso porque a ciência que inspirou o autor grego foi aquela em que a religião grega e as discussões de filósofos, físicos, matemáticos coexistiam e se imbricavam.

Já na obra de Wells, enxergamos uma grande influência das teorias de Charles Darwin, acerca da seleção natural das espécies, teorias que estavam em seu auge, tanto em A guerra dos mundos (1898), quanto em seus primeiros romances, $A$ máquina do tempo (1895) e A Ilha do Dr. Moreau (1896). Na contemporaneidade a influência do darwinismo ainda é forte na composição de textos de ficção científica, tanto que as obras de Wells e de outros autores, como George Orwell e sua Revolução dos Bichos (1945), ainda é bastante lida e estudada. Contudo, questões sobre o tempo e espaço ganham cada vez mais espaço e percebemos que a física quântica, a astrofísica e outras ciências que surgem a partir do século XX influenciam na composição da ficção científica como um todo e que contribuem para uma complexibilização do alienígena dos últimos tempos.

Na chamada Trilogia do Comando Sul, escrita por Jeff Vandermeer, composta por três livros lançados em 2014: Aniquilação, Autoridade e Aceitação, os seres alienígenas não 
possuem uma forma, manifestam-se apenas por meio de uma fronteira invisível que modifica todo o meio ambiente que cerca e as pessoas que lá ousam entrar. Questões de geografia e biologia irão perpassar toda obra, mas podemos destacar também o papel da psicologia nesses romances.

Outra história contemporânea de seres extraterrestres também se aventura por discussões científicas menos convencionais é o conto "História de sua vida", do estadunidense Ted Chiang, que discute principalmente questões de Linguística. Na narrativa, dois cientistas são chamados pelo Coronel Weber, líder do Exército dos Estados Unidos da América, para estudarem os alienígenas que chegaram à Terra, o físico Gary Donnelly e a linguista Louise Banks. Havia doze aparelhos extraterrestres nos EUA e cento e doze no mundo. O Coronel apresenta a Louise uma gravação que eles haviam realizado com sons emitidos pelos alienígenas, mas a gravação "soava vagamente, como um cachorro molhado sacudindo a água do pelo" (CHIANG, 20165). A ideia do exército era de que Louise fizesse a tradução da mensagem gravada sem manter contato com os seres alienígenas, contudo ela constata que o trato vocal daqueles seres era radicalmente diverso do humano e afirma que só seria possível caso tivesse contato efetivo com eles. Em função disso, ela é enviada para um dos espelhos/aparelhos alienígenas em companhia do já citado físico, entretanto, ao longo de todo o conto, é ela, com sua ciência linguística, e não Gary Donnelly, que protagonizará o contato, o qual é o nó fundamental que rege toda a trama narrativa. Logo, é a Linguística e a Hermenêutica, e não a Física, o centro narrativo de uma ficção científica, chamando a

5 Como se trata de uma versão de e-book Kindle, as páginas não serão citadas. 
atenção para a perspectiva heideggeriana de tecnologia, conforme Adam Roberts, que representaria um ponto de vista sobre o mundo, um modo de ver o homem e as coisas que o rodeiam. Articulamos a Hermenêutica relacionada à Linguística, porque, no caso do conto, Louise tem que lidar não apenas com a decifração de uma linguagem estranha, mas dar sentido a ela, interpretando-a. Gary, o físico, acaba por atuar de forma secundária no enredo; pode-se até dizer que sua principal função, além de ser confidente da linguista Louise, é conceber juntamente com ela uma filha.

Convencionalmente entende-se a narrativa de ficção científica como aquela que tem em sua base uma questão relacionada à ciência. Gernsback (Apud CAUSO, 2003, p.52) define a "scientifiction" como "um encantador romance entremeado de fato científico e visão profética". Muitos dos estudiosos da ficção científica, seguindo a linha de Gernsback, caracterizam-na como uma espécie de literatura em que a ciência deve fazer-se presente, gerando no leitor quase sempre uma expectativa de que essa ciência deve relacionar-se à área de exatas ou quando muito à de biológicas, porém raramente se cogita a vinculação de ciência à área de humanas. Conforme Adam Roberts (2018) elucida, alguns críticos literários, ao definirem a ficção científica, fazem-no considerando sua relação de afinidade com a literatura fantástica: "a diferença se encontra em um discurso materialista, científico, quer a ciência evocada esteja ou não em acordo com a ciência que conhecemos hoje" (ROBERTS, 2018, p.39). Por essa acepção, já se percebe que o sentido de ciência esgarça-se um pouco e amplia seu campo de atuação. Adiante, na conclusão do primeiro capítulo do seu livro $A$ verdadeira história da ficção científica, 
Adam Roberts (2018, p.60) defende que a "FC é mais bem definida como ficção tecnológica, desde que não encaremos tecnologia como sinônimo de engenhocas, mas, em sentido heideggeriano, como um modo de enquadrar o mundo, manifestação de uma perspectiva fundamentalmente filosófica". Enfatizamos esse aspecto porque pode causar estranhamento no conto de Chiang: a ciência posta em relevo ser a Linguística, da Humanas.

O conto insere-se na coletânea de contos intitulada História da sua vida e outros contos (2016), de autoria do autor estadunidense Ted Chiang, já agraciado com os Prêmios Nebula, Hugo e Locus por sua produção no campo da ficção científica. O conto "História da sua vida" teve sua adaptação para o cinema com o filme intitulado A chegada (2016), dirigido por Denis Villeneuve. Nesta parte do presente ensaio, jogaremos luz especialmente sobre como são configurados esses seres maravilhosos, os alienígenas, na diegese criada por Chiang, bem como da relação que tais alienígenas estabelecem com os humanos, por meio de um elemento tão importante para entender as diferenças entre seres e entre mundos: a linguagem - esta, que, no conto, é o principal presente que os alienígenas nos oferecem.

No conto de Chiang, a narrativa possui dois movimentos discursivos diferenciados que se completam, se superpõem, se embaralham e dialogam, seja de forma sutil ou desvelada: um movimento conta a história do contato da linguista, Dra. Louise Banks, convocada pelos militares dos Estados Unidos da América para traduzir a linguagem dos alienígenas que chegaram ao planeta Terra; o outro movimento revela-se como uma espécie de carta que Louise escreve para sua filha, uma carta em que 
a linguista revelará que possui a visão da morte da menina. Desconstruindo uma lógica narrativa tradicional, o conto não se inicia com a narrativa do contato, mas com a narrativa da visão. A desconstrução ocorre na medida em que se espera que inicialmente se fale primeiro do acontecimento inicial (o contato) que possibilitou o outro acontecimento posterior (visão do futuro); entretanto a inversão é repleta de sentido, uma vez que essa visão do futuro é possibilitada pelo contato de Louise Banks, a linguista, com a linguagem dos alienígenas, a qual é caracterizada por desenhos semagráficos que articulam "ideias complexas, todas ao mesmo tempo" (CHIANG, 2016), em todas as direções. Nesse sentido, não há uma linearidade sintática que subordina tudo à ordem, por exemplo, de passado-presente-futuro, e então o futuro pode vir naturalmente anteposto ao passado.

Alguns podem porventura questionar se essa narrativa seria um drama ou uma ficção científica, já que há a morte da filha como um dos motivos da narrativa. Há dois problemas que estão na base dessa indagação: o primeiro relativo ao gênero e o segundo ao estatuto estético. Em relação ao segundo ressaltamos que há ainda hoje um enorme preconceito em torno da produção e da recepção da ficção científica em função de ela ser vinculada frequentemente à literatura de massa e, nessa linha de entendimento, é muitas vezes e erroneamente caracterizada como uma literatura de menor qualidade estética; entretanto, esse preconceito trata-se de fato de um pré-conceito ipsis litteris, como defendemos ao longo deste ensaio, ou seja, de um julgamento anterior mesmo à experiência, uma vez que não se pode julgar uma literatura sem, antes de tudo, lê-la, sem experimentar o prazer estético inerente à leitura que se 
faz dela. Todavia, isso vale não só para uma literatura considerada, de antemão, trivial, como a novela de detetives ou a ficção científica; tal postura deve ser válida também para textos que geralmente são considerados como alta literatura. Muitas vezes, por exemplo, falta poesia em livros de poesia ou falta dramaticidade em textos dramáticos. Na área de produção relacionada à ficção científica, por exemplo, vimos que a obra de H.G. Wells tem uma indiscutível qualidade literária.

É, portanto, a leitura do discurso inscrito em uma narrativa de ficção científica que nos permite apreciar se ela possui ou não qualidade literária, e não simplesmente a sua inserção em um gênero vinculado usualmente à literatura trivial. No caso de "História de sua vida", o discurso ficcional foge radicalmente da fórmula que compõe a narrativa trivial, como a linearidade sequencial ou a veiculação de significados simplistas; pelo contrário, sua tessitura discursiva e ficcional ergue-se de modo a tornar complexa a construção do enredo, das personagens, do jogo entre temporalidades e espacialidades, da condução retórica do narrador, enfim, possibilitando a deflagração de sentidos múltiplos e polissêmicos.

Quanto ao aspecto relativo ao gênero, deve-se considerar que, mesmo após tantas revoluções na história da arte que evidenciaram o hibridismo, em geral há ainda uma insistência em dividir, categorizando e separando em espaços distintos, textos que devam pertencer a esse gênero e não àquele; contudo os textos, e especialmente os literários, muitas vezes fazem uso do hibridismo para gerar potenciais efeitos de sentido, como ocorre em "História da sua vida", que é uma narrativa que conjuga muito habilmente 
elementos dramáticos e de ficção científica; logo, não há motivo para evidenciar um gênero em detrimento do outro.

Uma das categorizações mais recorrentes no âmbito da ficção científica é a de ficção científica hard e soft, elucidada por Roberto Belli (2012, p.94-5). A primeira compõe-se de narrativas cujo núcleo do enredo é a própria ciência; já a ficção científica soft coloca no cerne do enredo os relacionamentos entre as personagens e as questões de ordem muito mais social do que científica. Particularmente, não somos adeptas às delimitações redutoras, entretanto, de posse dessa informação, podemos deduzir que o conto de Chiang aproxima-se muito mais de uma ficção soft, porque, ainda que tenha toda uma exploração de recursos e elementos da ciência linguística, é a humanização do alienígena e principalmente a humanização do humano (Louise), que está no centro da trama.

Devemos ressaltar que o drama desvelado não seria possível ser configurado da forma tão ímpar como aparece no conto sem os elementos da ficção científica. Não se trata de uma relação qualquer, mas de uma humana que, tratando o alienígena como sujeito e não como mero objeto, recebe dele um presente: a sua linguagem, uma linguagem que dará a ela e aos demais homens terem ciência de seu presente, de seu passado e de seu futuro. A riqueza do desvendamento de uma linguagem capaz de ler o futuro, presente ofertado por um extraterrestre é que desencadeará na trama o drama de Louise, pois, mesmo sabendo que terá uma filha e que esta morrerá ainda adolescente, ela decide, ainda com tanta dor (a dor de uma perda antecipada), ter a filha e contar a ela a história de sua vida. 
A posse da linguagem alienígena por Louise acontece de forma gradativa. Em seu contato humanizador, Louise começa a estudar não somente a língua falada, como também a escrita deles e vai se apropriando de um modo completamente diferente do nosso de grafar a escrita. A princípio Louise percebe que não era uma escrita alfabética e supõe que fosse ideográfica, porém, logo depois de algumas experimentações, ela percebe que era uma escrita feita por meio de logogramas, cuja configuração não era estática, mas se movimentava. Como os corpos dos heptápodes ${ }^{6}$, que não tinham direção definida, nem definitivamente trás, nem definitivamente frente, a escrita deles era lida em várias direções possíveis e em função dessa natureza pluridirecional e pluriespacial essa linguagem era também pluritemporal, açambarcando o que já havia acontecido e o que ainda estava no porvir. Após deixarem esse legado, o legado de sua linguagem, aos humanos terrestres, os alienígenas evadem da Terra. A maioria das pessoas não entende a evasão tão repentina, mas Louise recebe o presente como uma nova posse. Apesar de amarga a posse, é ela que fará Louise conquistar um novo olhar sobre o mundo e rever os limites de sua humanidade e dos outros: "em comparação aos espelhos dos heptápodes, assim meus colegas pareciam mais distantes que os alienígenas. O familiar estava longe, enquanto o bizarro estava ao alcance das mãos" (CHIANG, 2016). Léo Godoy Otero (1987, p.14), ao fazer uma leitura das ideias do autor Theodore Sturgeon, afirma que ficção científica em geral tem sua qualidade mais elevada quando a narrativa é desenvolvida em torno da problematização da condição humana, como vemos irromper no conto de Chiang. 
Lembremo-nos de que Gernsback (Apud CAUSO, 2003) define a ficção científica por meio de duas presenças: a do fato científico propriamente dito e a da visão profética. Parece-nos que Chiang contempla muito bem ambas as presenças e faz de seu conto um exemplo rico de ficção científica. A predição do futuro seria um elemento que faria parte da fenomenologia do metaempírico, já que, em nosso atual mundo empírico, tal predição situa-se no plano da impossibilidade lógica. Observemos que o metaempírico não tem existência no ambiente de recepção atual da leitura que aqui se faz do conto, mas não inviabiliza que essa existência situe-se em um porvir próximo ou distante.

Em nosso entendimento, o novum, nessas narrativas de alienígenas, como as que focalizamos neste ensaio, são os próprios alienígenas, como dito anteriormente, na medida em que eles nos apresentam novas e inusitadas formas de experiências, mentalidades e possibilidade de olhar o mesmo - o nosso mundo -, porque, como afirma Patrick Parrinder (Apud ROBERTS, 2018, p.37), "ao imaginar mundos estranhos [ou seres estranhos, acrescentamos], acabamos vendo nossas próprias condições de vida em uma perspectiva nova e potencialmente revolucionária".

O contato com esse novum, o alienígena, é estarrecedor no conto, Louise dá um pulo quando o primeiro deles entra em seu campo de visão pela grande diferença corporal que apresenta:

Parecia um barril suspenso no ponto em que seus sete membros se encontravam. Era radialmente simétrico, e qualquer um dos membros podia servir como braço ou perna. $\mathrm{O}$ que estava à minha frente caminhava em quatro pernas, com três braços não adjacentes curvados junto à lateral do corpo. Gary os chamou de "heptápodes". (CHIANG, 2016) 
Além disso, os membros deles não aparentavam juntas visíveis, era uma anatomia completamente diferente da humana, "com olhos em todos os lados, qualquer direção seria a da frente" (CHIANG, 2016). Apesar da grande diferença do alienígena e de esta ter provocado na linguista um susto enorme, o contato segue de forma tranquila, humanizada e humanizadora, pois Louise tenta travar um diálogo em que as afinidades, e não as diferenças, sejam ressaltadas, por isso ela também faz questão de nomeá-los com apelidos carinhosos - Melindrosa e Framboesa. Assim, o modo como eles são "demonstrados" no início pode causar estranhamento, porém, depois, com todo o contato diário de Louise com eles, ao leitor é desvelada uma face menos horrífica do ser extraterrestre, a despeito de todas as brutais diferenças que apresentam em relação à "normalidade" humana. Utilizamos o vocábulo "demonstrados" e não "representados", como seria mais usual, porque entendemos, com Roland Barthes (2007, p.21), que o real não é "representável, mas somente demonstrável". Mesmo sendo uma "realidade" da ordem do metaempírico, é uma realidade que pretende um diálogo com mundos possíveis - o nosso e o dos alienígenas.

Nas histórias de ficção científica, aparecem frequentemente dois tipos de alienígenas, como estamos defendendo desde o início deste ensaio: "aqueles que chegam a nós como 'invasores hostis' e aqueles que chegam como 'modelos de comportamento'" (SLUSSER; RABKIN Apud GINWAY, 2010, p.53). Para M. Elizabeth Ginway (2005, p.20), os "alienígenas servem muitas vezes como os alter egos da humanidade, como representações do admirado e/ou temido". Eles são, em geral, imagens alteradas de nossa humanidade. Via de regra, como esclarece Filipe Furtado (2017, p.137), eles são retratados como 
"coisas", porque são da ordem do indizível e do inenarrável. Como demonstramos, no primeiro momento do conto de Chiang, parece que a narrativa vai seguir a linha de demonstração do alienígena como o monstro a ser temido, todavia, logo depois essa face do mal, que é configurada pela diferença (o mal e o feio são sempre o diferente de nós), dissipa-se e vemos o trabalho de Chiang com alienígenas que são apresentados como doadores de um bem.

É interessante como a narrativa de Chiang escapa do que se espera normalmente, pois, os alienígenas, mesmo apresentando uma forma totalmente distinta e monstruosa, não são hostis e não oferecem perigo. Nós, leitores, somos surpreendidos por esses extraterrestres e os humanos de sua história, em sua grande maioria, parecem não aceitar que eles chegaram sem intenções maldosas. Como dissemos, Wells criou um sustentáculo para o que as histórias de invasões alienígenas viriam a ser e o seu modelo tem sido reproduzido constantemente desde então. Acostumamo-nos com os perigosos extraterrestres e nos esquecemos daqueles possíveis sábios seres extraterrenos, como o gigante de Voltaire, Micrômegas.

Voltaire, filósofo iluminista do século XVI, escreveu Micrômegas no ano de 1752 e, como em toda sua obra, nesse conto filosófico explora algumas de suas principais defesas, como a das liberdades civis e sua oposição às rígidas imposições religiosas. Micrômegas é um ser extraterrestre gigantesco que vive no planeta Sirius e contém um grande conhecimento acerca das questões do universo; por isso decide viajar até o sistema solar para conhecer seus habitantes e discutir com eles seus conhecimentos. Em Saturno, encontra um povo dotado de muita inteligência, mas ainda menor do que a sua e leva consigo um companheiro para explorar os demais planetas. 
Em Marte, não encontra nenhum tipo de vida e em um salto chega à Terra, que inicialmente também Ihe parece desabitada. Depois de um olhar mais atento, que só é possível por meio de um diamante que funciona como uma lupa, Micrômegas percebe que pequeníssimos seres vivem na Terra e conversa com eles. As discussões de Micrômegas sempre buscam investigar o que esses pequenos habitantes do planeta Terra conhecem e o extraterrestre se surpreende com o quanto o conhecimento de física, geometria e matemática são avançados em nosso planeta. Contudo, quando pergunta sobre questões existenciais como, de onde aqueles seres vieram, para onde irão, porque existem, cada um dos filósofos com quem ele conversava responde de uma forma. $\mathrm{O}$ gigante percebe que não há um consenso nesses temas e promete aos humanos que Ihes enviará um presente contendo todas essas respostas.

Micrômegas, assim como os alienígenas de "História de sua vida", presenteia os humanos com um conhecimento. Contudo o presente desse gigante é bem diferente daqueles outros, trata-se de um livro em branco, uma grande ironia acerca das certezas. O sábio Micrômegas sabe que muitas vezes é impossível se chegar a respostas absolutas, especialmente quando se tratam de questões existenciais.

Voltaire, que era grande fã de Newton, buscava em sua escrita ironizar e abandonar os fundamentos teocêntricos para dar lugar ao pensamento racional e científico. Sua obra apresenta um alienígena que é fundamental para a problematização iluminista, mas que, principalmente, antecipa uma literatura que terá maior expressividade no século XIX, com Wells, e sua relevância se reflete ainda hoje, como podemos perceber na forte influência no conto de Ted Chiang. 
Percebemos que o extraterrestre não é demonstrado de forma una, no cinema e, especialmente, na literatura. Eles podem nos presentear ou tentar nos destruir, podem até mesmo precisar de nossa ajuda e serem nossos amigos. Buscamos mostrar neste ensaio que apesar de o E.T. ocupar várias vezes um lugar marginal, assim como aquele da ficção científica, corresponde a um importante ser maravilhoso ao longo dos séculos e que sempre disse muito sobre os homens e sua humanidade ou desumanidade. O alienígena, que tem seu auge no século $X X$, mas que sempre esteve presente na imaginação de escritores, é uma presença indispensável e insubstituível nos textos em que aparece. A Guerra dos mundos não seria a mesma e não causaria tanto impacto até hoje se fosse apenas uma guerra de países, Micrômegas não seria tão relevante para o pensamento racionalista se fosse somente a representação de um Deus, Uma história verídica de Luciano seria apenas mais uma obra tentando reproduzir o sucesso de $A$ Odisseia se suas personagens se encontrassem com seres míticos ou invés de extraterrestres e "A história de sua vida" pareceria uma história do século passado se não tivéssemos o presente alienígena, mas sim uma bola de cristal. Nesse sentido, em todas essas obras, destacamos que o uso de elementos da ficção científica na composição das suas tramas revela-se como um potencial e frutuoso recurso estético.

\section{REFERÊNCIAS}

BARTHES, Roland (2007). Aula. São Paulo: Cultrix.

BELLI, Roberto C. (2012). Fiç̧ão científica: um gênero para a ciência. Blumenau: Edifurb.

BURLESON, Donald R. (2007). The Alien. In: JOSHI, J. T. (Org.). Icons of horror and the supernatural: an encyclopedia of our worst nightmares. London: Greenwood Press. 
CARPENTIER, Alejo (1987). A literatura do maravilhoso. São Paulo: Vértice.

CAUSO, Roberto de Sousa (2003). Ficção científica, fantasia e horror no Brasil: de 1875 a 1950. Belo Horizonte: Editora da UFMG.

CHIANG, Ted (2016). A história da sua vida e outros contos. Rio de Janeiro: Intrínseca. [e-book em kindle].

FURTADO, Filipe (2018). "Fantástico Modo". In: E-Dicionário de Termos Literários (EDTL). CEIA, Carlos (Coord.). In http://www.edtl.com.pt. Acesso em Nov.2018. (2017). O fantástico: procedimentos de construção narrativa em H. P. Lovecraft. Rio de Janeiro: Dialogarts Publicações.

GINWAY, M. Elizabeth (2005). Ficção científica brasileira: mitos culturais e nacionalidade no país do futuro. Roberto de Sousa Causo (Trad.). São Paulo: Devir. GINWAY, M. Elizabeth (2010). Visão alienígena: ensaio sobre a ficção científica brasileira. São Paulo: Devis.

LUCIANO (s/d). Uma história verídica. Lisboa: Editorial Inquérito.

OTERO, Léo Godoy (1987). Introdução a uma história da ficção científica. São Paulo: Lua Nova.

ROBERTS, Adam (2018). A verdadeira história da ficção científica-do preconceito à conquista das massas. São Paulo: Seoman.

VOLTAIRE (2007). Micrômegas e outros contos. São Paulo: Hedra.

WELLS, H.G. (2016). A guerra dos mundos. Rio de Janeiro: Suma de Letras. 


\section{A REPRESENTAÇÃO DO OUTRO NO CINEMA FANTÁSTICO: O CASO DE A FORMA DA ÁGUA (2017), DE GUILLERMO DEL TORO}

Alexander Meireles da Silva (UFG) Gabriela Spinola Silva (UFG)

Recebido em 04 nov 2018. Alexander Meireles da Silva é Doutor em Literatura Aprovado em 11 mar 2019.

Comparada (UFRJ). Está vinculado à UFG-Regional Catalão, onde atua na Graduação em Letras - Curso de Português, Curso de Português e Inglês e no Mestrado em Estudos da Linguagem. Produção bibliográfica: Capítulo de livro - a modernidade monstruosa de $\mathrm{H}$. P. Lovecraft em A sombra de Innsmouth" (As nuances do gótico: do setecentos à atualidade / 2017); Capítulo de livro - "A nossa guerra dos mundos: $\mathrm{H}$. G. Wells e a marginalização do povo no Fantástico brasileiro" (Tessituras literárias: Cultura, identidade e outras artes / 2017); Livro - Literatura Inglesa para brasileiros: curso completo de literatura e cultura inglesa para estudantes brasileiros (2005). É Membro do Grupo de Pesquisa Estudos do Gótico; Membro do Grupo de Pesquisa Nós do Insólito; Membro do GT ANPOLL Vertentes do Fantástico Ficcional. Suas áreas de interesse de pesquisa se concentram na Fantasia, Gótico, Horror, Ficção Científica e Weird Fiction. Lattes: $\quad$ http://lattes.cnpq.br/8325920517508979. Página pessoal: www.fantasticursos.com. Canal: https://www.youtube.com/fantasticursos E-mail: prof.alexms@gmail.com 
Gabriela Spinola Silva é Bacharel em Tradução pela Universidade Federal de Uberlândia (2017), atualmente mestranda em Estudos da Linguagem na UFG/RC, com pesquisa sobre tradução intersemiótica. Seus trabalhos mais pertinentes são: "Pelo direito de desobedecer: o filme 'Disobedience', de Sebastián Lelio, como tradução intersemiótica do livro homônimo de Naomi Alderman", apresentado em simpósio na III Feira Literária de Catalão e I Congresso de Leitura e Literatura Contemporânea (2018); e "O palavrão em Deadpool: Uma análise comparativa entre legendas oficiais e legendas de fãs", apresentado em conjunto com Francine de Assis Silveira na XXXVII Semana do Tradutor e II Simpósio Internacional de Tradução (2017). Participante do grupo de pesquisa "Do Fantástico aos fantásticos: Facetas do Insólito na Contemporaneidade". Áreas de interesse de pesquisa são Tradução Audiovisual, Tradução Intersemiótica e Literatura Fantástica. Lattes: http://lattes.cnpq. br/9286192559852580 E-mail: tradspinola@gmail.com

Resumo: Desde a sua gênese, o Cinema tem servido como veículo para a manifestação das ânsias que consomem as mais diversas sociedades que dele se valem. Uma das mais peculiares formas dessas manifestações é o Cinema Fantástico - no qual, através da apresentação de criaturas monstruosas ou maravilhosas, submundos incríveis, universos paralelos e galáxias distantes, é possível ver a inserção do Outro e das visões que os respectivos realizadores dos filmes (tal qual a sociedade em que estivessem inseridos) têm a respeito destes (INAYATULLAH e BLANEY, 2004; TODOROV, 1999). Um exemplo desta questão, logo nos primórdios da sétima arte, é o clássico Viagem à Lua (1902), de Georges Méliès, o qual traz os selenitas - as criaturas que habitam a Lua - trajando vestimentas tribais, lanças e expressões similares a demônios, em uma escolha de indumentária remetente aos nativos das colônias francesas na África no final do século XIX e 
início do século XX. Desta forma, o presente artigo busca discorrer sobre a representação do Outro ao longo da história do cinema mainstream ocidental, e traçar uma análise a respeito de como todos os personagens do filme A forma da água (2017), de Guillermo del Toro ${ }^{1}$, em especial a criatura anfíbia monstruosa no centro da narrativa, refletem tais questões acerca da alteridade. Palavras-chave: Alteridade; Cinema Fantástico; $A$ Forma da Água.

Abstract: Ever since its first baby steps, Cinema has been an outlet for Humanity's greatest anxieties. One of the many peculiar ways these anxieties have been put out is in fantasy films. Through its monstruous and marvellous creatures, astonishing underworlds, parallel universes and galaxies far, far away, we are presented to the Other and to the views the filmmakers (and the societies they are inserted in) have of them (INAYATULLAH e BLANEY, 2004; TODOROV, 1999). In the dawn of cinema, the classic $A$ trip to the Moon (1902), directed by Georges Méliès, is a prime example of this. It brings out the selenites (the living creatures that inhabit the Moon) dressed in tribal garments, bearing spears and with faces similar to devils, in a very clear reference to the French colonies in Africa by the end of the 19th century and the beginning of the 20th century. Therefore, this work intends to dwell on how the Other has been represented throughout mainstream ocidental Cinema history, and to analyze how all the main characters in The shape of water (2017), directed by Guillermo del Toro, reflect such questions regarding otherness, particularly when it comes to each of their relationships to the monstruous amphibian creature the movie's plot revolves around.

Keywords: Otherness; Fantasy Films; The Shape of Water.

1 IMDB. Guillermo del Toro. In https://www.imdb.com/name/nm0868219/?ref_=tt_ov dr. Acesso em 01.Nov.2018. 


\section{INTRODUÇÃO: UMA CONTEXTUALIZAÇÃO HISTÓRICA}

Nascido nos estertores do século XIX, o Cinema surgiu como evidência dos efeitos da Revolução Industrial sobre diversas esferas da experiência humana na Era Vitoriana, se colocando como uma nova expressão artística fomentada pela demanda de atendimento dos desejos da massa pelo novo e da reprodutibilidade da arte. Como tal, em seus primeiros momentos o Cinema trouxe um alinhamento com todo o discurso vigente ao longo do século XIX, marcado pelo Imperialismo, o impacto das ideias de Charles Darwin sobre a evolução das espécies e sua aplicabilidade em outros campos sociais e as pesquisas sobre a mente humana. Estes fatores alimentaram debates políticos, teológicos, científicos que capturaram a imaginação de escritores na criação de mundos imaginários habitados por seres fantásticos. Logo, duplos emergindo da psique de cavaleiros distintos (O estranho caso de Dr. Jekyll e Mr. Hyde, 1886), vampiros aristocratas oriundos do leste europeu (Drácula, 1897), criaturas bestiais antropomórficas, resultado de experiências insanas (A ilha do Dr. Moreau, 1896), ou marcianos invasores na Londres finissecular (Guerra dos mundos, 1897) surgiram na literatura fantástica da época, fornecendo também matéria prima para o nascente Cinema. Percebe-se aí que a inserção do Outro no cinema se deu pela apresentação de monstros dos mais diversos tipos - alienígenas, criaturas mitológicas, mutantes, vampiros e outros seres. De fato, a forma como o autor de uma narrativa (seja ela cinematográfica, literária, quadrinhística ou como for) escolhe, deliberadamente, representar o Outro, costuma dizer mais sobre o próprio autor e seu contexto histórico-cultural do que necessariamente sobre o Outro propriamente dito. 
Neste sentido, este trabalho tem como objetivo analisar como a criatura monstruosa apresentada na produção cinematográfica A forma da água (2017), dirigida por Guillermo del Toro, se coloca como um espelho a partir do qual outros personagens encontram sua própria monstruosidade moral e social.

Tome-se como exemplo a produção Viagem à Lua (1902), de Georges Méliès, baseado nos romances Da Terra à Lua (1877), de Júlio Verne e Os primeiros homens na Lua (1901), de H. G. Wells. Ainda que o filme A conquista do ar (1901), de Ferdinand Zecca seja a obra pioneira de Ficção Científica no Cinema, foi a produção de George Mèliés que se tornou um marco para a História do Cinema por ser a primeira obra cinematográfica a usar "efeitos especiais" (técnicas de stop-motion que foram resultado de anos de prática de Méliès como ilusionista) (SCHOEREDER, 1986, p.24). O filme traz os selenitas - criaturas que habitam na Lua - representados com vestimentas caracterizando-os como demônios e utilizando lanças. Essa escolha de indumentária é interpretada largamente como sendo uma referência aos nativos das colônias da França na África durante o final do século XIX e início do século XX.

Já durante o período entreguerras, é por meio do Fantástico que o Cinema começa a se desvincular da imagem de produto de mero entretenimento para as massas para começar a mostrar o seu amadurecimento enquanto veículo das ansiedades de suas sociedades, algo expresso no surgimento do Expressionismo Alemão. Nascida no universo das Artes Plásticas, esta expressão artística capturou o espirito de ceticismo, desencanto e pessimismo prevalente na Alemanha após a sua derrota na Primeira Grande Guerra, gerando um grau de incerteza sobre o futuro e sobre a 
autonomia do indivíduo dentro de um sistema em que ele se via vítima de forças superiores a ele; forças estas que provocavam uma crise identitária traduzida em personagens vítimas de hipnotizadores (O gabinete do Dr. Caligari, 1920), vampiros (Nosferatu, 1922) ou cientistas loucos (Metrópolis, 1927).

Com $O$ Gabinete do doutor Caligari, o cinema fantástico deslanchou - especialmente na Alemanha do pós-guerra. Os cenários distorcidos, expressionistas, do filme, que rejeitavam qualquer pretensão de realismo, a narrativa fragmentada, as atuações hiperestilizadas e a sensação de insegurança paranoica se uniam para expressar a atmosfera de uma nação derrotada, traumatizada, sem confiança na própria identidade, vendo inimigos tanto internos quanto externos. As sombras pintadas deste filme e dos seus sucessores na era do cinema mudo pareciam antecipar - conforme apontaram Siegfried Kracauer e outros críticos - as sombras que se aprofundariam na sociedade alemã nos anos vindouros. (KEMP, 2011, p.42)

Ainda no período entreguerras, e após o destaque dado para as criaturas fantásticas no cinema europeu (em especial o alemão, vide o já citado $O$ gabinete do doutor Caligari e $M$, o vampiro de Dusseldorf, de Fritz Lang), os estúdios de cinema da Universal, nos Estados Unidos, começou a produzir longas baseados em obras literárias pertencentes à tradição da Literatura Gótica europeia. Partindo diretamente das obras literárias ou de textos teatrais que adaptavam essas obras para o palco, esses filmes se alinharam com a situação de profunda crise econômica vivenciada pelos Estados Unidos da época. Neste cenário, os americanos iam ao cinema entrar em contato com monstros ficcionais que 
subvertiam os seus mundos e acabavam sendo derrotados pela ordem levando-os a esquecer, por algumas horas, dos horrores reais do seu dia a dia. Assim, começando por O Corcunda de Notre Dame (1923), adaptação do romance homônimo de 1831 do escritor francês Victor Hugo, a Universal começou a construir um universo cinematográfico monstruoso que teria sequência com 0 Fantasma da Ópera (1925). A partir daí, e após outras produções, a Universal entrou nos anos da década de 1930 com uma sucessão de filmes que se comunicavam com os crescentes medos da América, começando por Drácula (1931), primeira adaptação oficial do romance do irlandês Bram Stoker contando com o ator húngaro Bela Lugosi para dar vida ao senhor dos vampiros. Na sequência, e mais uma vez bebendo de fontes literárias, foi a vez de Frankenstein (1931) chegar às telas, trazendo o ator Boris Karloff para viver o monstro de Mary Shelley. Chama a atenção aqui como a força simbólica do monstro de Victor Frankenstein dentro do contexto de sua época acabou eclipsando o nome de seu criador e desde essa produção falar de Frankenstein é pensar na criatura e não no jovem cientista. Foi por conta da força dessas criações que a Universal gradualmente construiu o que ficaria conhecido como "Monstros da Universal", cuja caracterização ainda permeia o imaginário popular quando falamos de monstros. A própria criatura de Frankenstein verde com parafusos no pescoço vem dessa época, tal qual o Drácula de Bela Lugosi com sua capa, que se tornou uma indumentária típica do vampiro desde então. Para quem diz que as sequências excessivas são o pior sintoma do estado do cinema atual, vale ressaltar que essa franquia rendeu vinte e seis filmes sobre as mais variadas criaturas: vampiros, 
lobisomens, homens invisíveis e o monstro da lagoa (o qual viria a inspirar o deus-peixe de $A$ forma da água).

Paralelo às criaturas góticas, a figura do Outro também surgiu na vertente fantástica da Ficção Científica no Cinema. Disseminandose nas revistas pulp de então, quando o próprio nome "Science Fiction" passa a nomear republicações de histórias de Edgar Allan Poe, Júlio Verne e H. G. Wells, a Ficção Científica norte-americana refletiu também no Cinema o contexto racista e xenofóbico da América. O Outro aqui assume a forma de alienígenas ligados ao Oriente. Como explica Adam Roberts em A verdadeira história da ficção científica (2018) ao falar das aventuras cinematográficas de Flash Gordon nas matinês dos anos 30 contra o Imperador Ming, regente do planeta Mongo:

Não se trata, é claro, de um texto neutro no âmbito ideológico; a representação de Ming, em particular, leva a noções essencialistas de "tirania oriental e decadência", noções que são racistas e que se intensificaram em 1940, quando os Estados Unidos entraram em guerra com o Japão (embora possa ser acrescentado que, enquanto os mongonianos nas histórias em quadrinhos eram desenhados com traços raciais do Extremo Oriente, a versão para o cinema os estiliza com traços caucasianos; após o sucesso do seriado, isso também foi adotado pelos quadrinhos. (ROBERTS, 2018, p.386-387)

No pós-guerra, durante a Guerra Fria, e passada a crise econômica, a representação do Outro no cinema mainstream americano começa a direcionar-se para o chamado pânico anticomunista e a ascensão da Era Atômica. Como exemplos de filmes que retratam esse pânico anticomunista, temos $O$ monstro 
do ártico (1951), A ameaça veio do espaço (1953), Vampiros de almas (1956), Os invasores de Marte (1953) e, em especial, Guerra dos Mundos (1953), baseado no livro homônimo de H.G. Wells de 1897, o qual é visto como uma crítica pungente ao Imperialismo inglês na África e na Ásia. A versão dos anos 50, contudo, retrata o pânico anticomunista, enquanto a versão de 2005 representa os alienígenas como seres infiltrados, numa analogia ao momento de guerra ao terror vivido pelo país após o 11 de setembro. Imperialismo - Comunismo - Terrorismo. Percebe-se neste ponto como o monstro alienígena é retrabalhado para atender as angústias e receios de cada público conforme o contexto sociohistórico em que estão inseridos.

Ainda que os anos da década de 1960 tenham começado ainda refletindo a paranoia anticomunista da década anterior com o filme $O$ terror veio do espaço (1962), adaptação cinematográfica do romance $O$ Dia das Trifides, de John Wyndham, gradativamente 0 fascínio despertado tanto pelo espaço advindo da corrida espacial da Guerra Fria quanto pela crescente busca de diversas minorias por representatividade social acabaram provocando novos olhares sobre a representação do monstruoso. Assim, mulheres, negros, homossexuais e jovens norte-americanos contrários a conflitos nos quais os Estados Unidos se envolviam, passaram a subverter o status quo por meio de estratégias diversas, dentre elas, a Literatura e o Cinema. Aqui temos o abandono e a crítica à visão celebrada nos primeiros anos da Ficção Científica norte-americana propagada em revistas como a Amazing Stories e a Astonishing Stories e que encontrou sua expressão em heróis espaciais como Buck Rogers e Flash Gordon. Antes, era comum que esses emissários 
desembarcassem em algum planeta habitado por criaturas nativas e plantassem sua bandeira em nome de alguma federação planetária, desconsiderando as opiniões dos habitantes desse mesmo planeta. Esse quadro, todavia mudaria ao longo da década de 1960 quando o Outro se torna o centro da narrativa, colocado em contraste com um representante da ideologia dominante. O filme 2001: Uma Odisseia no espaço (1968) ilustra bem esse momento de desconstrução do monstruoso ao apresentar alienígenas que subvertem não apenas a sua representação física na tradição pulp, mas também que critica a pretensa superioridade cultural do ser humano (leia-se homem, anglo-saxônico, cristão) diante do universo.

Já nos anos 70, a ficção científica com seus aliens chegou ao mainstream após o impacto de 2001 e se consolidou com blockbusters como Star Wars: Uma Nova Esperança (1977), e produções que traziam visões diferentes sobre o alienígena, conforme visto em Contatos imediatos de terceiro grau (1977) e Alien, O Oitavo Passageiro (1979) - no qual este último, segundo Jordan (1984, Apud SILVA, 2010), o alienígena intruso, apresenta características como a pele negra; além de matar e infectar suas vítimas em um ato violento que remete ao estupro, em uma ação historicamente atribuída ao homem negro dentro de contextos urbanos.

Há de se dizer, ainda, que a Guerra do Vietnã em muito influenciou as produções cinematográficas dos anos 60, 70 e até 80, durante o período da chamada contracultura. Segundo o próprio George Lucas, Star Wars é uma alegoria à guerra, com os mocinhos rebeldes representando o Vietnã, e não a pátria amada chamada EUA. Apesar da dicotomia maniqueísta presente excessivamente em franquias como Rocky e Rambo (cujos inimigos eram sempre 
retratos unidimensionais de russos ou de indivíduos de qualquer outra nacionalidade cujo país de origem tivesse um posicionamento comunista, ou de qualquer maneira avesso à hegemonia estadunidense), foi possível ver, nessas décadas, vários filmes relatando os horrores da guerra e subvertendo a visão maniqueísta do comunista como o Outro absoluta e indiscutivelmente malvado e cruel, e questionando o próprio patriotismo. Há exemplos nítidos disso em variados filmes de guerra, como Apocalypse Now (1979), Platoon (1986) e Nascido para matar (1987).

Já nos anos 80, temos uma relativa "Era de Ouro" da ficção científica no cinema, na qual os filmes blockbusters começam a se consolidar graças ao sucesso de Star Wars (1977) e Tubarão (1975) na década anterior. Aqui, é preciso listar Blade Runner (1982) como um exemplo essencial de representação do Outro na ficção científica. Baseado no romance Androides sonham com ovelhas elétricas (1968), do escritor norte-americano Philip K. Dick, o protagonista do filme é um caçador de replicantes rebeldes, ou seja, androides que subverteram sua programação original. Neste universo, os replicantes são escravizados em outros planetas colonizados pela humanidade e fogem para a Terra (onde são ilegais, portanto, acabam por ser caçados e "aposentados", ou seja, mortos) a fim de tentar viver uma vida mais digna, ainda que breve e limitada. Ao final do filme, o plot twist definitivo: Deckard se descobre como o Outro que ele mesmo caça e, assim, abandona o posto de blade runner e foge com a amada Rachael, também uma replicante. Outros filmes notáveis são A mosca (1986), Aliens (1986), Predador (1987), E.T.: O extraterrestre (1982) e os outros dois filmes da primeira trilogia de Star Wars. 
Durante os anos 90, houve o início da utilização da computação gráfica de forma extensiva. Os avanços tecnológicos na área da computação permitiram que vários filmes pudessem ser feitos e tornassem realidade a imaginação de roteiristas e diretores, algo expresso no início da década em filmes como Jurassic Park (1992). Durante essa década ocorreu o apogeu dos disaster movies: grandes produções nas quais há alguma catástrofe iminente, seja a destruição do planeta através de ameaças externas (ou internas, tais como desastres naturais), seja algum desastre mais particular, como acidentes em meios de transportes (vide Titanic (1997)). Na primeira opção, encontram-se filmes como Independence Day (1996), cujo tratamento dado aos alienígenas em muito contrasta com a forma como eles são representados em filmes como Contato (1997). Mais uma vez nota-se a utilização do Outro para dar forma às ansiedades de momentos finiseculares, comumente marcada como épocas de crise de valores e convicções. Como sinaliza Jeffrey Jerome Cohen sobre o lugar do monstro no ensaio "A cultura dos monstros: sete teses" (2000): "Por sua limiaridade ontológica, o monstro aparece, de forma notável, em épocas de crise, como uma espécie de terceiro termo que problematiza o choque entre extremos" $(2000$, p.30-31). Ainda sobre alienígenas, o filme MIB: Homens de preto (1997) captura o lugar do Outro ocupado pelo imigrante dentro dos Estados Unidos no final do século XX no sentido de que eles de fato não pertencem ao país e, portanto, despertam suspeitas. Como explica Adam Roberts em Science Fiction (2000):

Eles são, então, estrangeiros internalizados, alienígenas disfarçados, e como tais eles representam um perigo ao corpo político, um perigo que é o trabalho dos 'Homens de Preto' 
manter sob controle. /.../ O que é claro, contudo, é que o ônus do filme representa o imigrante como visualmente do americano 'normal', e possuidor de um potencial perigoso. (2000, p.138 - tradução nossa) ${ }^{2}$

O cinema da primeira década do século XXI foi encontrar nos super-heróis o principal meio de expressão da alteridade. Ainda que adaptações de super-heróis sempre tenham marcado a história do Cinema (o primeiro super-herói adaptado para o Cinema foi o Capitão Marvel em 1941), foi a partir do início dos anos 2000 que se inicia um verdadeiro nicho cinematográfico: o "Cinema de super-herói" - o qual perdura até o momento de elaboração deste artigo - foi marcado pela produção regular e constante de longas com o tema. Os primeiros representantes desse momento são Blade (1998) e X-Men (2000).

Os X-Men, criação do quadrinista Stan Lee para a editora Marvel nos anos 60 do século $\mathrm{XX}$, traz um grupo de pessoas possuidoras de poderes especiais que os levam a serem hostilizados pelos demais seres humanos. Este grupo de super-heróis surgiu em um momento histórico de extrema tensão racial nos Estados Unidos. Esse foi o momento em que líderes negros como Martin Luther King e Malcolm X articularam estratégias de resistência e visibilidade para os afro-americanos contra a ideologia excludente da sociedade americana da época. Interessante perceber que em um primeiro momento os personagens retratavam a situação dos negros contra o racismo na América. Todavia, no universo 2 "They are, then, internalised outsiders, aliens in disguise, and as such they represent a danger to the body politic, a danger that it is the job of the 'Men in Black to keep under control. /.../ What is clear, though, is that the burden of the film represents the immigrant as visually different from the 'normal' American, and as possessing a dangerous potential." 
cinematográfico - e no novo milênio - a mensagem se alterou. No segundo filme da franquia, X-Men 2 (2003), há uma cena em que a mãe de Bobby Drake, o Homem de Gelo (Shawn Ashmore), ao se ver confrontada com a descoberta de que o filho é mutante, questiona: "mas você já tentou não ser um mutante?" (X-MEN 2 , 2003). O grupo, agora, representa os LGBTs e o tratamento a eles dispensado. Da mesma forma, em X-Men 3: 0 confronto final (2006), o personagem anjo é confrontado pelo pai que busca uma cura mutante para o seu filho. "Você não" (X-MEN 3, 2006), diz o pai ao filho ao perceber que ele também é um mutante, em uma clara alusão à mesma situação vivenciada por inúmeros jovens que decidem se assumir como sendo LGBTs para a família conservadora. Mais recentemente, Deadpool 2 (2018) tratou da mesma questão com bastante fôlego: o antagonista do filme é um viajante do tempo que vai atrás de um garoto de 12 anos, traumatizado em uma clínica de tratamento mutante, que irá se tornar um assassino em série após matar o diretor da clínica onde estava internado. Temas como abuso sexual e terapias de conversão para LGBTs são expostos e discutidos através da temática mutante.

Alguns outros filmes dos anos 2000 e 2010 a serem notados pelo seu tratamento a respeito do Outro são Distrito 9 (2009), Guerra dos mundos (2005), Avatar (2009), No limite do amanhã (2004), A.I.: Inteligência Artificial (2001) e A chegada (2016).

\section{O CASO DE A FORMA DA ÁGUA (2017)}

Neste trabalho, será analisado o filme A forma da água (2017), dirigido pelo mexicano Guillermo del Toro, e vencedor de quatro 
Oscars (Melhor Direção, Melhor Filme, Melhor Trilha Sonora e Melhor Design de Produção).

Nascido em Guadalajara, no México, Del Toro dedicou praticamente toda sua carreira aos monstros, criaturas e histórias fantásticas. Seu primeiro longa, Cronos (1993), conta a história de um objeto místico e secular que concede - através da inoculação do veneno de uma aranha que habita em seu interior - a vida eterna a quem o detém, mas também provoca uma sede insaciável de sangue a seu portador; transformando-o, portanto, em uma espécie de vampiro. Alcançou certa notoriedade com seu terceiro longa, $A$ espinha do diabo (2001), que trata de um garoto de 12 anos deixado em um orfanato durante a Guerra Civil espanhola, o qual é recebido de forma hostil e agressiva pelas demais crianças do local e, então, recebe a visita do fantasma de um garoto assassinado no mesmo orfanato, que impele o protagonista a executar uma vingança em seu nome.

Depois, del Toro consolidou-se na indústria cinematográfica estadunidense como um nome dedicado ao Fantástico com duas adaptações de quadrinhos, lançadas em sequência. $\mathrm{O}$ primeiro filme, Blade $\|^{3}$ (2002), mal recebido pela crítica (contém, no site agregador de notas e críticas Rotten Tomatoes, uma porcentagem de aprovação, vinda da crítica especializada, de apenas 57\%, e uma nota média de 5,9 pontos em 10), é baseado em um personagem da Marvel Comics, e é a sequência de Blade (1998), uma das duas adaptações de quadrinhos da Marvel que seria a gênese do "cinema de super-herói" que vemos hoje, com superproduções de

3 ROTTEN TOMATOES. Blade II (2002). In https://www.rottentomatoes.com/m/blade_ii. Acesso em 01.Nov.2018. 
adaptações de quadrinhos das mais diversas editoras, em especial Marvel e DC. A despeito da citada má recepção crítica de Blade I/ (2002), este filme abriu as portas para que del Toro trabalhasse em outro projeto de notoriedade baseado em quadrinhos: Hellboy ${ }^{4}$ (2004). Baseado na série de quadrinhos de Mike Mignola para a editora Dark Horse, Hellboy (2004) conta a história de um demônio, invocado e materializado para a Terra, diretamente do Inferno, por nazistas, quando bebê, o qual foi descoberto pelas forças Aliadas e criado tal qual um menino humano comum por um cientista a fim de que, quando crescesse, combatesse as forças das trevas - tais quais bruxas e nazistas. Ao contrário da obra antecessora na filmografia de del Toro enquanto diretor, Hellboy (2004) foi bem recebido pela crítica (com $81 \%$ de aprovação da crítica no site Rotten Tomatoes e uma média de 6,8 pontos em 10). Hellboy (2004) também marca o início da parceria do diretor com o ator Doug Jones, que viria a encarnar várias de suas criaturas. Aqui, ele é o anfíbio Abe Sapien. Em O labirinto do fauno ${ }^{5}$ (2006), ele interpreta o fauno que dá nome ao filme, e também o enigmático Homem Pálido. Em A forma da água (2017), objeto de estudo deste artigo, é ele a criatura anfíbia mística no centro da narrativa.

O reconhecimento internacional de Guillermo del Toro como diretor, contudo, veio com o longa seguinte: $O$ labirinto do fauno (2006), o qual conta a história de uma menina de 10 anos, Ofelia, que se muda para o norte do país devido ao casamento de sua mãe com um oficial do exército. Em meio aos dramas familiares

4 ROTTEN TOMATOES. Hellboy (2004). In https://www.rottentomatoes.com/m/hellboy. Acesso em 01.Nov.2018.

5 ROTTEN TOMATOES. O Labirinto do Fauno (2006). In https://www.rottentomatoes. $\mathrm{com} / \mathrm{m} /$ pans_labyrinth. Acesso em 01.Nov.2018. 
e conflitos armados entre o exército e os rebeldes resistentes remanescentes da Guerra Civil espanhola, a garota encontra refúgio em um labirinto, vizinho à mansão onde mora, no qual descobre um submundo repleto de criaturas fantásticas, tais como o fauno do título. Indicado a seis Oscar, O labirinto do fauno (2006) saiu com três estatuetas: Melhor Fotografia, Melhor Direção de Arte e Melhor Maquiagem. Foi indicado, ainda, a Melhor Roteiro Original, Melhor Trilha Sonora e Melhor Filme Estrangeiro.

Com temas já recorrentes na filmografia de del Toro (o abandono na infância a existência de um submundo surreal e fantástico, e a Guerra Civil espanhola como pano de fundo, sendo o primeiro item e o último particularmente convergentes com $A$ espinha do diabo (2001)), O labirinto do fauno (2006) é o seu filme mais criticamente aplaudido: possui 95\% de aprovação no já citado site Rotten Tomatoes. Com um orçamento modesto de US\$19 milhões (nada comparado aos US\$54 milhões de Blade // (2002), ou os US\$ 66 milhões de Hellboy (2004)), o longa faturou quatro vezes o seu orçamento, rendendo US\$\$83 milhões ao redor do mundo, de acordo com o site estadunidense Box Office Mojo ${ }^{6}$, que agrega dados a respeito de bilheterias e orçamentos de filmes.

Os longas seguintes de del Toro ocupando a cadeira da direção foram Hellboy II: O exército dourado (2008), Círculo de fogo (2013), A colina escarlate (2015) e A forma da água (2017). Todos estes filmes têm em comum a presença de criaturas fantásticas: em Círculo de fogo (2013), criaturas monstruosas (denominadas Kaiju) despertam nos mares. Em A colina escarlate (2015), entidades misteriosas 6 BOX OFFICE MOJO. Guillermo del Toro movie box office results.In https://www. boxofficemojo.com/people/chart/?view=director\&id=guillermodeltoro.htm. Acesso em 01.Nov.2018. 
assombram a casa na qual os protagonistas moram e os atormentam. Em A forma da água (2017), que se passa durante a década de 60 do século $X X$ em uma instalação secreta de pesquisa do governo americano na cidade de Baltimore, Maryland, uma servente muda descobre uma criatura anfíbia que está sendo mantida presa em cativeiro e sofre tortura por parte de seus captores. A justificativa para esta situação é o estudo empreendido pelo governo dos EUA visando o envio de um homem ao espaço e, por consequência, a derrota dos comunistas o quanto antes. A servente, chamada Elisa, então elabora um plano junto a seus amigos para poder resgatar a criatura e libertá-lo.

No filme, há uma gama de personagens pertencentes a minorias, e as relações entre eles (e a forma como cada um deles trata outros personagens e outras minorias) é o cerne da narrativa. Elisa (Sally Hawkins) é muda, pois sofreu uma lesão nas cordas vocais quando bebê. Giles (Richard Jenkins), seu vizinho, é um gay de meia-idade solitário em um momento histórico préStonewall, em um país em que todos os estados ainda possuíam leis anti-sodomia. Zelda (Octavia Spencer), sua melhor amiga, que entende ASL (a língua de sinais americana) e faz a ponte entre Elisa e o resto do mundo, é uma negra em pleno período de apartheid americano. O Dr. Robert Hoffstetler (Michael Stuhlbarg), que tanto se interessa e simpatiza com a criatura anfíbia humanoide, é um comunista infiltrado. O grande vilão do filme, Richard Strickland, é um homem, hétero, branco, com família de comercial de margarina e masculinidade frágil, que se vê como centro do mundo e tem medo (e ódio) de tudo aquilo que é diferente de si. O filme, em sua essência, trata das relações humanas e da forma como cada 
um de nós, em nossos contextos sociais e históricos, enxergamos o Outro. O Outro "absoluto" aqui é o ser anfíbio humanoide (chamado Charley, de acordo com membros da produção do filme em postagens da internet), o qual, em sua região de origem na Amazônia, é considerado um deus, e recebe oferendas e presentes dos nativos, mas ao ser capturado pelos EUA (mais especificamente por Strickland), é alvo de tortura e ódio.

Inayatullah e Blaney (2004) afirmam que há três maneiras de se lidar com o Outro: negando-o, excluindo-o ou copiando-o. Os autores trabalham com características de Estados em um Sistema Internacional, mas é possível aplicar sua análise em contextos de análise de indivíduos.

Já Tzvetan Todorov (1999) aprofunda o problema da alteridade e o divide em três eixos:

1. Plano axiológico: plano no qual há julgamento de valor do Outro.

Ex.: o Outro é bom; o Outro é feio;

2. Plano praxiológico: plano no qual se evidencia a ação de aproximação ou distanciamento em relação ao Outro.

Ex.: adoção de valores do Outro; assimilação do Outro e imposição de outra visão;

3. Plano epistemológico: plano referente à ação de conhecer.

Ex.: opção por reconhecer a identidade do Outro como própria dele; opção por ignorar se o Outro possui identidade própria.

Aqui, analisaremos a relação dos personagens citados (Elisa, Giles, Zelda, Hoffstetler e Strickland) com o Outro - e não apenas Charley. 
1) Elisa: a protagonista se relaciona bem com todos os Outros que Ihe são apresentados, exceto por Strickland. Ela abraça e cultiva a amizade com Giles, um homem gay, e Zelda, uma mulher negra, e a despeito de sua deficiência vocal, se comunica plenamente com ambos. Ela aceita os Outros como sendo bons, assimila-os em sua vida, e reconhece e respeita a identidade deles como própria de cada um. Ela pouco interage com Hoffstetler, mas o reconhece como sendo bom (inclusive sinaliza para ele, e Zelda interpreta, "você é um homem bom, Dr. Hoffstetler"), aceita e é grata pela sua ajuda no "sequestro" de Charley, e não demonstra, em momento algum, objeção à sua identidade enquanto comunista (o qual deveria ser o "inimigo"), ou seja, o aceita. Sua relação problemática é apenas com Strickland, o qual reconhece como um homem machista e inconveniente logo no primeiro encontro, na cena do banheiro, aos 17 minutos de filme; e depois, na cena em que ele a assedia, aos 58 minutos do filme. Ao realizar esforços para a libertação de Charley, ela rejeita os valores de Strickland e, portanto, rejeita sua visão de mundo. Sua relação mais significativa, contudo, é com Charley: ao conhecer a criatura, ela (por ser ela mesma um Outro em relação aos demais personagens com quem convive, devido a sua deficiência) o vê com bons olhos, e o ensina a língua de sinais. Pode-se dizer que ela assimila-o enquanto Outro e impõe sua língua e seus gostos (apresentando-o à música), porém não o faz com a intenção de "colonizá-lo", por assim dizer, e sim, para fins de comunicação, visto que a única forma de saber se a criatura seria capaz de se comunicar era apresentá-la a algum meio de comunicação. Podemos notar aqui um breve paralelo com A chegada (2016) na forma como Elisa consegue se comunicar com Charley, enquanto 
Strickland não atinge os mesmos resultados porque foi truculento e o via como uma ameaça desde o início, enquanto no filme de Denis Villeneuve os EUA conseguem, a duras custas, se comunicar com os aliens e entender qual o propósito deles no planeta apenas após o esforço descomunal da protagonista Louise Banks (Amy Adams) em ser didática e ensiná-los a se comunicar, assim como em aprender o idioma deles; ao passo em que os demais países, que trataram os aliens como uma ameaça sem ao menos tentar conhecê-los, não alcançam os mesmos resultados. Por fim, Elisa reconhece a identidade de Charley como sendo própria dele e o defende, pois se vê nele, como é possível ver na cena da briga com Giles aos 45 minutos de filme.

2) Zelda: Zelda pouco interage com outros personagens além de Elisa e, quando há alguma interação, sua opinião tende a converger com a da amiga (ou vice-versa). Em relação a Charley, ela se mostra muito mais preocupada com a possibilidade de se envolver em encrencas do que com a segurança ou sequer o bem-estar da criatura; mas apoia as decisões de Elisa mesmo assim. Desta forma, não o desconsidera enquanto Outro, e permanece, de uma forma geral, indiferente a ele; mas contribui ativamente para que Charley seja liberto.

3) Giles: Talvez seja o personagem mais problemático dentre os personagens pertencentes a minorias apresentados neste filme. Giles é um homem gay, cuja única relação (razoavelmente) saudável com algum Outro apresentado é a que tem com Elisa: ele preza pela amizade dela, adota a sua língua de sinais, e reconhece a sua identidade enquanto mulher e muda. Contudo, mesmo aí, há problemas: na lanchonete, aos 13 minutos de filme, enquanto tenta 
impressionar o funcionário do estabelecimento, ele segura as mãos de Elisa para que ela pare de sinalizar, ou seja, sente vergonha em ser visto por um potencial par amoroso com uma pessoa deficiente. Aos 14 minutos, quando Elisa troca de canal na televisão e acaba parando em um canal de notícias que está exibindo um protesto da comunidade negra contra a segregação, provavelmente no sul dos EUA, ele ordena, agressivamente, mesmo não estando presente na sala para ver o que se passava, e tendo identificado a situação apenas pelo som, que ela mude de canal, pois não queria ver aquela "coisa horrível". Ele também se omite, aos 49 minutos do filme, quando um casal negro entra na lanchonete e é expulso pelo balconista que o havia rejeitado e o expulsaria, também, segundos depois, apenas por ser gay, da mesma forma que expulsou o casal negro apenas por serem negros. Ele se manifesta apenas após o casal se retirar do estabelecimento, dizendo "você não precisava falar assim com eles". Aos 45 minutos de filme, ele também renega a ideia de resgatar Charley, dizendo explicitamente que se trata de uma aberração, demonstrando-se incapaz de empatizar até quando Elisa traça um paralelo entre a criatura e ela mesma. Após ser acidentalmente atacado por Charley, a 1h19 de filme; ele, ao mesmo tempo em que simpatiza, também age de forma condescendente, dizendo que "ele comeu Pandora, não foi culpa dele. Ele é uma criatura selvagem, não podemos pedir que seja outra coisa.", insinuando que a criatura não possuísse racionalidade. A seguir, ele demonstra nojo ao ser tocado por Charley. Algumas cenas depois, mais especificamente 1h32, ao descobrir que Charley o havia curado através daquele mesmo toque pelo qual demonstrou nojo, ele pede a Elisa que deixe que a criatura fique com eles por mais tempo. Dessa forma, podemos 
inferir que Giles tende a renegar ao Outro, aceitando-o e vendo de forma empática somente quando Ihe for conveniente e lhe trouxer alguma vantagem.

4) Hoffstetler: No filme, Hoffstetler pouco interage com a maioria dos personagens, sendo o Outro, para ele, majoritariamente Charley e Strickland. Quanto a Charley, Hoffstetler (cujo nome, na verdade, é Dmitri) o vê com os bons olhos de um cientista que se encontra fascinado com a sua descoberta - fascínio esse que inclusive ultrapassa até a sua lealdade à Pátria Mãe, a então União Soviética, pois ele mostra-se relutante em matar a criatura quando apresentado a essa obrigação pelos demais companheiros russos infiltrados. Ele vê Charley de uma forma positiva (como diz o próprio em 1 h de filme, "uma criatura bela e complexa"), busca aproximação ao demonstrar o desejo de estuda-lo de uma forma não invasiva, e reconhece e respeita a criatura e o fato dela ser uma espécie de divinidade em sua região de origem. Quanto a Strickland, Dmitri o tem como antagonista dentro do trabalho, o vê com maus olhos, como um homem cruel, renega fortemente seus valores desde a raiz (afinal, Strickland representa os americanos, Dmitri é russo, e estão em plena corrida espacial), e opta pelo desprezo pela identidade de Strickland, em especial ao ajudar Zelda e Elisa a raptarem Charley - plano que ele mesmo não concebeu, mas que revela que gostaria de ter concebido, afinal, não lhe agradava a ideia de matar a criatura.

5) Strickland: O personagem de Michael Shannon destoa fortemente de todos os outros personagens do filme. Branco, hétero, classe média, religioso, pai de família de comercial de margarina, é esse o vilão em um filme premiado, dirigido por um dos diretores latinos 
mais conhecidos e conceituados da última década. Strickland tem uma visão extremamente limitada do Outro. Ele acha peculiar o fato de Zelda não ter irmãos e diz "isso não é comum para a sua gente", aos 26 minutos de filme, demonstrando já o que pensa sobre os negros. Um pouco depois, ainda na mesma cena, ele menciona, direcionado a Zelda, que "você pode achar que aquela coisa parece humana, porque anda com as duas pernas. Mas nós fomos criados à imagem do Senhor. E você não acha que Deus se parece com aquilo, né?", se referindo ao Charley. Quando Zelda diz que não sabe qual a aparência de Deus, ele replica, ainda, que Deus "parece humano, como eu. Ou como você. Talvez mais como eu, presumo", dando assim a entender que se vê como mais próximo e semelhante a Deus simplesmente por ser, ao contrário de Zelda, homem e branco. Aos 30 minutos de filme, ele chega a casa e é recebido pela família tradicional: esposa dona de casa, dois filhos, cenário típico de comercial de margarina. Em determinado momento, ele se senta à mesa, olha para o nada, apático; e, enquanto o resto da família se move ao fundo, diz "isso é a América". O recado do diretor não poderia ser mais claro: os EUA da família tradicional varrem diariamente para baixo do tapete a hipocrisia, junto à poeira que acumula em cima de seus móveis. Um pouco mais à frente, aos 32 minutos de filme, durante uma cena de sexo, é possível ver que ele mal encosta na esposa; o ato se torna algo mecânico, por obrigação. Quando a esposa começa a falar durante o ato sexual, ele literalmente a silencia, colocando a mão machucada e sangrenta por cima da boca dela, pedindo-a para que não fale mais. Nessa cena fica claro que, além do desprezo por negros, também há o desprezo pelas mulheres, independente da cor: ao silenciar a esposa, ele se 
isola dentro do próprio ato sexual e deixa claro que ninguém ali importa a não ser ele mesmo - seu próprio prazer é o único foco, ele crê ser o centro de todas as ações que o envolvem. Strickland passa o filme inteiro desprezando Hoffstetler pelo seu interesse em manter Charley vivo e, ao final do longa, atira no soviético, o agride e o larga na chuva para morrer. Além destas situações, há ainda que ser comentada a forma como ele vê - e trata - Charley (ou, como ele mesmo diz, "the asset": o item, o objeto, a coisa). Ele despreza a criatura em todos os níveis possíveis e a vê como um ser vivo absolutamente selvagem e nojento. Ele tortura Charley repetidamente, e perde dois dedos ao ser mordido pela criatura. É interessante notar que ele faz uma reconstrução dos dois dedos mas, mesmo assim, conforme seu ódio e sua perseguição pela criatura vão aumentando, os dedos vão necrosando até que, em determinado momento, ele mesmo os arranca, em uma clara representação visual do conceito de que sentimentos negativos nos destroem - aqui, isto ocorre de forma literal. Tal situação seria facilmente solucionável caso ele visse Charley como um Outro digno de respeito e compreensão, visto que o ser anfíbio curou Giles da calvície e de seu ferimento, mas infelizmente as informações de que Charley seria capaz de se comunicar com eles e que tem sentimentos passam completamente incólumes por Strickland, cujo ódio e desprezo por tudo aquilo que não se encaixe em seus ideais tradicionais e cristãos o cega e prejudica, levando-o a morte ao fim do terceiro ato, logo após, ironicamente, reconhecer Charley como um Deus.

Intrinsecamente ligado à história do ser humano, o monstro vem assumindo diferentes formas ao longo dos séculos sempre 
advertindo, fascinando, protegendo, refletindo, observando os rumos da cultura humana. Desde a Antiguidade, quando guardava as fronteiras do mundo conhecido e civilizado nos confins da terra até os dias de hoje, quando se torna um espelho no qual o ser humano contemporâneo vê seus medos e desejos íntimos, ele sinaliza, como em A forma da água, a necessidade do ser humano em enxergar além das utopias da igualdade entre os tipos humanos para valorizar as diferenças no processo de criação de uma sociedade tolerante, dinâmica e reconhecedora do papel da mudança como força motriz que faz a humanidade avançar.

\section{REFERÊNCIAS}

A FORMA da água (2017). Direção de Guillermo del Toro. Produção: J. Miles Dale, Guillermo del Toro. Toronto (CA): Bull Productions, Double Dare You (DDY), Fox Searchlight Pictures, TSG Entertainment.

COHEN, Jeffrey Jerome (2000). "A cultura dos monstros: sete teses". In: SILVA, Tomaz Tadeu da (Org.). Pedagogia dos monstros: os prazeres e os perigos da confusão de fronteiras. Belo Horizonte: Autêntica. (Coleção Estudos Culturais, 3), p.23-60.

GAZETA DO POVO. Apesar do que diz a Disney, Star Wars sempre foi político. In https://www.gazetadopovo.com.br/caderno-g/cinema/apesar-do-que-diza-disney-star-wars-sempre-foi-politico-cvab5t1e4dk64ievglvifo2cj. Acesso em 09.Jul.2018.

INAYATULLAH, Naeem; BLANEY, David (2004). International Relations and the Problem of Difference. Routlege.

KEMP, Philip (2011). (Org.) Tudo sobre cinema: Inglaterra. Rio de Janeiro: Sextante.

ROBERTS, Adam (2018). A verdadeira história da ficção científica: do preconceito à conquista das massas. Mário Molina (Trad.). São Paulo: Seoman.

ROBERTS, Adam (2000). Science Fiction. New York: Routledge, (The New Critical Idiom). 
SCHOEREDER, Gilberto (1986). Fiç̧ão Científica. Rio de Janeiro: Francisco Alves. SILVA, Alexander Meireles da (2010). "Além dos homenzinhos verdes: a representação da monstruosidade alienígena no fantástico afro-americano". In II COLÓQUIO NACIONAL DE ESTUDOS EM NARRATIVA: história e ficção no universo do fantástico. Uberlândia.

TODOROV, Tzvetan (1999). A Conquista da América: a questão do Outro. Beatriz Perrone Moisés (Trad.). 2.ed. São Paulo: Martins Fontes. 


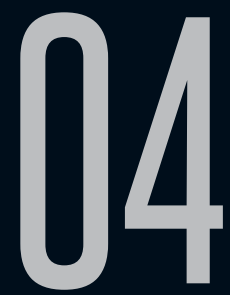

\section{SAGRADO, DE TOMÁS ELOY MARTÍNEZ: FIGURAS E MITOS REALISTA MARAVILHOSOS ${ }^{1}$}

Andre Mitidieri (UESC)

Luciana Mazzutti (IFBaiano)

Recebido em 30 set 2018. Andre Mitidieri é Doutor em Letras, área de Aprovado em 10 mar 2019. concentração em Teoria da Literatura, pela Pontifícia Universidade Católica do Rio Grande do Sul (PUCRS). Pós-Doutorado em Estudos Literários pela Universidade Federal do Rio Grande do Sul (UFRGS). Professor Titular de Literaturas Vernáculas no Curso de Letras da Universidade Estadual de Santa Cruz (UESC), nas áreas: Teoria Literária, História e Literatura. Produções bibliográficas mais significativas: MITIDIERI, André; CAMARGO, Flávio Pereira (Org) Literatura, homoerotismo e expressões homoculturais. Ilhéus: EDITUS, 2015. MITIDIERI, André Luis; SILVA, Denise Almeida; CALEGARI, Lizandro Carlos. O Quintana que (quase) ninguém viu. Frederico Westphalen: EdURI, 2012. MITIDIERI, André Luis. Como e porque (des)ler os clássicos da biografia. Porto Alegre: EDIPUCRS; IEL, 2010. V. Participação em grupos de pesquisa, grupos de trabalho, núcleos ou centros de pesquisa ou estudos Grupo de Pesquisa (CNPq): O Espaço Biográfico no Horizonte da Literatura Homoerótica - Líder do grupo; Programa de Extensão Revisões do Cânone (UESC) Coordenador. Em 2017, Melhor Trabalho de Iniciação Científica/Orientação de Tales Santos Pereira, PróReitoria de Pós-Graduação e Pesquisa da UESC. Em 2016, Destaque da Iniciação Científica/Orientação

1 Título em espanhol: Sagrado, de Tomás Eloy Martínez: figuras y mitos realista maravillosos. 
de Leandro Souza Borges Silva, Pró-Reitoria de PósGraduação e Pesquisa da UESC. Em 2015, Destaque da Iniciação Científica/Orientação de Tiago Calazans Simões, Pró-Reitoria de Pós-Graduação e Pesquisa da UESC. Em 2014, Melhor Projeto de Pesquisa/ Orientação de Tales Santos Pereira, Pró-Reitoria de Pós-Graduação e Pesquisa da Universidade Estadual de Santa Cruz (UESC). Em 2012, Homenagem Especial, XXXIII Feira do Livro de Alegrete e Troféu Mario Quintana, Diretoria de Cultura - Prefeitura Municipal de Alegrete. Áreas de interesse de pesquisa: Teoria literária, Diversidade sexual e de Gênero, Literatura Brasileira, Literaturas Hispânicas, Estudos Culturais. Lattes: http://lattes.cnpq.br/5629822206205508.

Luciana Mazzutti é Mestre em Letras: Linguagens e Representações (UESC), com a pesquisa financiada pela Coordenação de Aperfeiçoamento de Pessoal de Nível Superior (CAPES): A insólita hibridação do romance Sagrado, sob orientação do Prof. Dr. André Mitidieri. Professora EBTT-DE, em outubro de 2016 do Instituto Federal de Educação, Ciência e Tecnologia Baiano e, atualmente, Coordenadora de Pesquisa Substituta, do Instituto, Campus Alagoinhas. Áreas de atuação: Língua Portuguesa, Língua Espanhol e Respectivas Literaturas. Produções bibliográficas mais significativas: MAZZUTTI, LUCIANA HELENA CAJAS; RODRIGUES, INARA. (2016) Um olhar realista maravilhoso a partir d?A varanda de frangipani. Navegações (Impresso) (Porto Alegre), v.8, p.156. MAZZUTTI, L. H. C.; MITIDIERI, André Luis. Expressões conceituais do Insólito no espaço literário sulamericano. Signo (UNISC. Online), v.40, p.21-32, 2015. MITIDIERI, A.; GUIMARAES, L. B.; MAZZUTTI, L. H. C. (2013)Tomás Eloy Martínez e as (des)memórias de Juan Domingo Perón. Letras de Hoje (Online), v.48, p.431-440. Participação em grupos de pesquisa, grupos de trabalho, núcleos ou centros de pesquisa ou estudos Grupo de Pesquisa (CNPq): O Espaço 
Biográfico no Horizonte da Literatura. Áreas de interesse de pesquisa: Teoria literária, Diversidade sexual e de Gênero, Literatura Brasileira, Literaturas Hispânicas, Estudos Culturais. Lattes: http://lattes. cnpq.br/8394792874185199 E-mail: shanbarros@ gmail.com ou luciana.mazzutti@ifbaiano.edu.br

Resumo: Nesta investigação, estabelecemos um diálogo entre a obra literária Sagrado (1969) e a escrita autobiográfica, crítica e jornalística do autor Eloy Martínez, verificando a comunicação que firma com seus possíveis leitores. Destacamos a imbricação que o ficcionista argentino arquiteta ao relacionar a cidade argentina à personagem principal do romance em análise, autenticando o que afirmam, em jornais e publicações argentinos, outros intelectuais de grande porte. Também observamos que a narrativa, entendida como estória ou fábula, configura seus elementos de caráter realista maravilhoso a partir da espacialização ficcional da cidade de Tucumán e na órbita de sua personagem Bío. Esse protagonista, cujo nome intitula o primeiro capítulo da obra literária em estudo, torna-se representativo de uma sociedade repleta de tabus, mitos e tradições. Consideramos, neste ponto da pesquisa, a reterritorialização que, na concepção de Canclini (2003), completa um dos processos responsáveis pela hibridação. Nesse sentido, a personagem principal, em contato com outras "localizações", "relocaliza-se" e ressignifica bens simbólicos, sem desconsiderar a herança tucumana.

Palavras-chave: Insólito; Real Maravilhoso; Realismo Maravilhoso.

Resumen: En esta investigación, establecemos un diálogo entre la obra literaria y la escrita autobiográfica, crítica y periodística de Tomás Eloy Martínez, verificando la comunicación que firma con sus posibles lectores. Destacamos la imbricación que el ficcionista argentino arquitecta cuando relaciona 
la ciudad argentina al personaje principal de Sagrado (1969), autenticando lo que afirman, en periódicos y publicaciones argentinos, otros intelectuales de gran porte. También observamos que la narrativa, entendida como historia o fábula, configura los elementos de carácter realista maravilloso a partir de la espacialización ficcional de la ciudad de Tucumán y en la orbita del personaje Bío. Ese protagonista, cuyo nombre intitula el primer capítulo de la obra literária en estudio, se torna representativo de una sociedad repleta de tabus, mitos y tradicciones. Consideramos, en este punto de la pesquisa, la reterritorialización que, en la concepción de Néstor García Canclini (2003), completa uno de los procesos responsables por la hibridación. En este sentido, el personaje principal, en contacto con otras "localizaciones", "se relocaliza" y resignifica bienes simbólicos, sin desconsiderar la herencia tucumana.

Palabras-clave: Insólito; Real Maravilloso; Realismo Maravilloso.

Em seu primeiro romance, Sagrado, Tomás Eloy Martínez (1969) descreve, aparentemente, as experiências de Bío que, desde o nascimento até a vida adulta, ultrapassa barreiras familiares, sociais, culturais e religiosas. Tornar-se um grande boxeador, atender ao sonho de sua mãe, parece ser seu objetivo, mas a narrativa dá maior ênfase a sua decadência. A ascensão e o declínio do protagonista imbricam-se às condições históricas, político-econômicas e sociais da sua cidade, Tucumán, nesse romance dividido em três capítulos, intitulados respectivamente Bío, Andrés e Boni.

As personagens que constituem a narrativa e contribuem para o desenvolvimento da trama, em sua maioria, fazem parte da família de Bío, o protagonista. A mãe, cujo nome não é mencionado, além de criá-lo atendendo à tradição tucumana, participa diretamente 
da sua vida esportiva, dos seus treinos de boxe. O pai, com pouquíssimas participações na vida do filho, mostra-se importante, principalmente quando o livra da morte. As tias, muitas vezes sem nomes, fazem de tudo para perpetuar a união familiar e as práticas religiosas, vigiando para que todos obedeçam às orientações dadas pela doutrina judaico-cristã. O tio Judas, ao ser pego raspando as pernas, levou a família a ganhar o apelido de "Os Esquisitos".

Outras personagens colaboraram com essa denominação familiar: a mãe, que perfumava os bifes para saírem cheirosos após a digestão; a tia Matilde, que dormia entre caixas de bandagem enquanto as serviçais aplicavam loções de laranjeira para cuidar dos cachos; as avós Adelina - dos duzentos quilos, que desmaiava com as provocações da prima Osório - e Presbiteria, a qual costurou os cantos da boca a fim de parecer-se com Clara Bow, atriz americana de cinema que tinha a boca bem pequena. Além dessas personagens, vale citar Tia Rosa, que bordava sem parar a árvore genealógica da família e, cada vez que alguém nascia ou morria, desfazia o bordado, recomeçando-o incansavelmente, e a solteirona Prima Osório, com quem o protagonista teve sua primeira relação sexual, personagem que afugentava os pretendentes de tanto abraçá-los e beijá-los, em um tipo de amor sufocante. Não menos estranhos, eram o tio Whebe, dono da mercearia onde a família costumava comprar, que dispunha os ganchos das carnes ao contrário; e tio Eloy, o barbeiro, que experimentava cortes esquisitos nos cabelos dos sobrinhos.

Por sua vez, Gosi é uma espécie de "zombi" ou "trickster" que, montado em uma bicicleta, aposta corrida com o pai de Bío e aparece e desaparece da narrativa nos momentos mais oportunos. O verbete "Zombi", sob a autoria de Maximilien Laroche (2007), no Dicionário 
de figuras e mitos literários das Américas (p.687-692), classifica o termo como personagem natural, diferente do "golem", que é artificial. No primeiro caso, trata-se de um "alter ego, um homem que outro homem, por magia ou artifício, trabalha e o submete ao seu governo" (p.691). Trata-se de um ser vivo e morto ao mesmo tempo, figura que varia dependendo da evocação: "em uma lenda africana, em um boato haitiano, numa notícia parisiense ou num filme de Hollywood" (p.687).

A figuração aterradora do zombi, na América Hispânica, pode apresentar-se de três formas: a) um sujeito maléfico; b) alguém comandado por um mestre, sem vontade própria; c) seres inofensivos, educados, simpáticos, mas travessos. Escritores haitianos, filiados ao Realismo Maravilhoso, retiram as características negativas, deixando de apresentá-lo como um estrangeiro, em procedimento de reterritorialização. Segundo Néstor García Canclini (2003), esse ato, precedido da desterritorialização, torna-se um desejo de "fixar signos de identificação, rituais que os diferenciem dos que estão só de passagem, são turistas ou... antropólogos curiosos para entender os cruzamentos interculturais" (p.325). Assim, a concepção de zumbi, em Sagrado (MARTíNEZ, 1969), difere das estabelecidas em outras territorialidades e ganha um novo significado, que compõe a interculturalidade própria da América do Sul, a levar em conta sua história e sociedades.

Segundo Rubelise da Cunha (2007), autora do verbete "Trickster" (p.641-647) no dicionário organizado por Bernd (2007), o termo predomina em estudos das literaturas ameríndias e define uma personagem ambígua e amoral que prega peças, podendo ser humano e animal, criador e destruidor, herói e anti-herói, mas 
também tornar-se vítima das próprias trapaças. No entanto, não se define por oposições binárias e hierárquicas, pois se origina de línguas e memórias culturais que não aceitam essa dicotomia. São seres que possivelmente sofrem mutações, em alguns momentos, considerados mensageiros entre o humano e o divino. A definição precisa impossibilita-se pelas várias formas e comportamentos que a figura assume em diferentes narrativas; mais do que uma conceituação, "é uma projeção da cultura ocidental com o intuito de entender e explicar um universo cultural distinto" (p.642).

Além de conviver com personagens estranhas como essa, muitas delas portadoras de significações figurais ou míticas constantes na cultura sul-americana, Bío conta ainda com os conhecimentos do treinador, Hermegildo Maziotti, que, acompanhado do massagista e do tesoureiro, leva-o para um centro de treinamento e juntos trabalham para que Bío se transforme em boxeador profissional. Após uma luta triunfante, o protagonista conhece Andrés, Severito e Boni, tornando-se amigo inseparável deles. Brigi, matrona da Casa de domesticación, desperta neles o desejo e a revolta pela forma como tratam os homens que servem a casa.

Sagrado (MARTÍNEZ, 1969) insere-se no Realismo Maravilhoso, pois aborda o discurso da realidade americana que, segundo Irlemar Chiampi (1980), "permite determinar as coordenadas de uma cultura, de uma sociedade, de uma linguagem hispanoamericana" (p.13). Essas coordenadas são visíveis no protagonista do romance, que não pode ser analisado fora de sua história pessoal nem das relações que estabelece com o contexto social, a fim de comprovar-se a importância da diversidade cultural estabelecida na sociedade e na família nele representadas. Já 
no início da narrativa, Martínez (1969) insere Tucumán como a realidade social e histórica à qual aponta:

o primeiro momento é eterno porque a primeira palavra é eterna e diz tudo. Essa máxima sempre ocupou um lugar privilegiado nos vestíbulos da minha família, e por mais voltas que lhe tenham dado, nenhuma das minhas tias pôde substituí-la. Nos anos de vacas magras, quando Tucumán criava tempestades puras e tremores de terra, voavam as tias com as saias alvorotadas a esconder a máxima nos armários e a buscar nos bazares antídotos para afugentá-la. ( p.13) ${ }^{2}$

Ao representar a cidade argentina no romance, Martínez introduz o leitor nesse universo ficcional e naturaliza eventos extranaturais. Sem assustar o leitor, o Insólito é estranho e conhecido; o receptor/leitor percebe o "oculto" como se estivesse sempre ali, presente, "escondido", ou seja, é familiar a ele. Após apresentado o espaço com características marcantes do Realismo Maravilhoso, é a vez de abordar o protagonista. Para tanto, o escritor argentino faz seleções que não devem ser consideradas casuais, pois, segundo Zilá Bernd (2007),

como se sabe, a escolha dos mitos pelos escritores não é inocente e sua inscrição no tecido literário é prevista para causar um impacto político e social. O imaginário no qual os mitos são apresentados mascara muitas vezes seu poder de desestabilização e contribui para a renovação social, lá onde os discursos racionais falharam. (p.545)

2 Texto-fonte: "El primer momento es eterno porque la primera palabra es eterna y dice todo. Esa máxima ha ocupado siempre un lugar privilegiado en los vestíbulos de mi familia, y por más vueltas que le hayan dado, ninguna de mis tías ha podido reemplazarla. En los años de vacas flacas, cuando Tucumán criaba puras tempestades y temblores de tierra, volaban las tías con las polleras alborotadas a esconder la máxima en los armarios y a buscar en los bazares contra-venenos para ahuyentarla" (MARTÍNEZ, 1969, p.13). 
Ao discorrer sobre o verbete "recém-nascido", no dicionário por ela organizado, Bernd (2007) assinala a eficácia do mito em textos literários, uma vez que fundamenta a ideia de renovação e recomeço: "A figura do nascimento de uma criança está, pois, desde os primórdios, associada à regeneração, à redenção e à salvação de uma determinada coletividade" (p.547). 0 anúncio do nascimento do filho do protagonista morto, em Écuê-Yambo-Ô, de Carpentier, segundo a estudiosa brasileira, configura uma "projeção utópica", relacionada a mudanças ocorridas no continente sul-americano, durante a Revolução Cubana.

O romance em estudo traz também um nascimento, ou melhor, um recém-nascido, que talvez venha para evidenciar a possibilidade de redenção, renovação e regeneração da sociedade tucumana. Bío conta um mês de nascido quando quase morre ao provar sorvete de amendoim. Seu pai, sua mãe e suas tias desesperam-se, pois o menino não comia e recusava qualquer líquido a ele oferecido. Sendo a morte iminente, após todas as tentativas para salvá-lo dentre elas, promessas e simpatias -, sem obterem resultado algum,

mamãe e as vizinhas conjuraram os Pregos de Cristo, amarraram Pôncio Pilatos em seus lenços e sacrificaram no altar do Senhor sabiás amarelos trazidos de Santa Cruz, os primeiros brotos de cana, a geleia que minha avó arrebatava ao coração das maçãs. Mas eu não deixava de desperdiçar a água legada por minha mãe e recusava os milagres: esgotei cisternas de minhas entranhas, lancei mão dos sortimentos de minhas moléculas. E no meio de tal seca, tomou conta de minha casa o vício do pranto. (MARTINEZ, 1969, p.16)

3 Texto-fonte: "Mi mamá y las vecinas conjuraron a los Clavos de Cristo, ataron en sus pañuelos a Poncio Pilato y sacrificaron en el altar del señor los tordos amarillos traídos 
Ainda com base no dicionário organizado por Bernd (2007), a partir da definição desenvolvida por Nubia Jacques Hanciau (p.282-288) para o verbete "feitiçaria", buscamos entender o valor simbólico do poder das metamorfoses e reutilizações próprias do "constante perambular, no indefinível e na passagem, de um estado para uma nova forma" (HANCIAU, 2007, p.287), em que tudo faz parte do incompreensível, inapreensível, impalpável. Associamos essa elucidação às práticas em que se mesclam crenças cristãs e não-cristãs, intrínsecas e admissíveis nos eventos insólitos, mas talvez desafiadoras para o pensamento moderno de tipo analítico, segundo Canclini (2003), "acostumado a separar binariamente o civilizado do selvagem, o nacional do estrangeiro, o anglo do latino etc." (p.XXXIII).

A moléstia vivida por Bío é desconhecida às lentes da ciência e da medicina, mas não aos olhos de seus conterrâneos, a miscelânea religiosa, por um lado, assinalada por promessas aos santos e, por outro, pelas simpatias e crendices populares, representa a diversidade cultural e religiosa presente na América do Sul, corroborando para que o leitor/receptor naturalize o extraordinário e não questione o Insólito. $\mathrm{O}$ amparo em crenças tradicionais ou místicas mostra como o núcleo familiar tucumano exemplifica a hibridação cultural que cerca o contexto sul-americano e permite a percepção do sujeito como sua parte integrante, assegurando a ideia de Canclini (2003) sobre o fato de as culturas populares não se extinguirem, sendo preciso buscá-las em outros lugares ou não-lugares.

de Santa Cruz, los retoños tempranos de la caña, la jalea que mi abuela arrebataba al corazón de las manzanas. Pero yo no cesaba de derrochar el agua legada por mi madre y rehusaba los milagros: agoté aljibes de mis vísceras, eché mano a los surtidos de mis moléculas. Y en medio de tal sequía, prendió en mi casa el vicio del llanto" (MARTINEZ, 1969, p.16). 
Desse modo, Martínez (1969) apresenta as dúvidas de Bío sobre a suposta sacralidade tucumana e como essa personagem migra na tentativa de reterritorializar-se, o que teria a ver com:

Os cruzamentos intensos e a instabilidade das tradições, bases da abertura valorativa, podem ser também [...] fontes de preconceitos e confrontos. Por isso, a análise das vantagens ou inconvenientes da desterritorialização não deve ser reduzida aos movimentos de ideias ou códigos culturais [...]. (CANCLINI, 2003, p.326)

Retomamos as contribuições de Canclini (2003) quando, em seu estudo, admite que o processo de migrações da América do Sul é assimétrico e esclarece que o objetivo dos processos de hibridação não resulta em conceber um sujeito que entra e/ou sai pacificamente da hibridação, mas que transita da desterritorialização à reterritorialização (ou seja, sai do campo e ingressa no urbano) com espontaneidade. Nesse trajeto, talvez seja decisivo continuar a "construir princípios teóricos e recursos metodológicos [para] tornar este mundo [...] mais convivível em meio a suas diferenças, e a aceitar o que cada um ganha e está perdendo ao hibridar-se" (p.XXXIX).

Nessa perspectiva, o Real Maravilhoso, basilar na elaboração do Realismo Maravilhoso, remete ao conceito ontológico, visto que "não é o resultado da criação do artista através de determinado procedimento formal, pois ele está ali" (ESTEVES; FIGUEIREDO, 2010, p.405). A diferença encontra-se na capacidade de perceber os elementos maravilhosos, assimilação possível através do reconhecimento do sujeito na cultura; caso contrário, passam sem ser percebidos ou, ainda, equivocadamente compreendidos, como algo essencialmente mágico ou deformado pelo escritor. 
Em Sagrado (MARTínEZ, 1969), o contexto social, cultural e religioso é exposto de maneira que leva o leitor à naturalização das ocorrências ficcionais, extraordinárias, irreais e/ou imaginárias. Os princípios em torno do sexo, como uma prática suja e pecaminosa, assim como a disciplina perante a obediência às tradições, à igreja e aos preceitos impostos pela sociedade, constituem não só as personagens, mas, principalmente, a construção do espaço social e intercultural que, por sua vez, estabelece marcas significativas da escrita realista maravilhosa de Martínez.

Quanto ao contexto socioeconômico representado na obra literária, o estudo desenvolvido por Daniel Campi (2003) - "Azúcar y trabajo. Coacción y mercado laboral en Tucumán" - assinala como o poder estabelecido nessa sociedade determinava obediência aos donos dos engenhos açucareiros, que comandavam a província argentina:

o empenho em constituir uma massa de assalariados modernos exigia impor às classes subalternas os valores subjetivos da elite sobre o trabalho, o uso do tempo vago, o ócio; especificamente, a legitimidade do direito à propriedade dos patrões sobre a força de trabalho. (CAMPI, 2003, p.250) ${ }^{4}$

Mesmo sob a determinação das elites tucumanas, os trabalhadores "se comportaram como atores históricos com capacidade para incidir em suas condições de existência" (CAMPI, 2003, p.251) $)^{5}$. O pensamento libertário dos proletários instituiu

4 Texto-fonte: "el empeño en constituir una masa de asalariados modernos exigía imponer en las clases subalternas las valoraciones subjetivas de la élite sobre el trabajo, el uso del tiempo, el ocio; especificamente, la legitimidad del derecho de propiedad de los patrones sobre la fuerza de trabajo" (CAMPI, 2003, p.250).

5 Texto-fonte: "se comportaron como actores históricos con capacidad para incidir en sus condiciones de existencia" (CAMPI, 2003, p.251). 
sérios obstáculos para que a disciplina e moralização elitista obtivessem sucesso. Essa postura contestadora associa-se ao evento insólito que, no romance em estudo, descreve uma possível tomada de poder através da invasão das formigas (trabalhadores) temida pelo casal de idosos (elite):

- Somos seus únicos inimigos - diz o velho, abraçado ao regador -. Entregamos aos bombeiros um esquema de suas galerias, uma lista de suas rainhas e um mapa de seus ninhos. Avisamos-lhes que têm campos de treinamento em Lules e uma frota de tanques para tomar o poder. Ninguém nos ouve, ninguém quer acreditar em nós. Estamos desesperados. Na fonte do quintal, as formigas instalaram um quartel general, os aeródromos e os parques de diversões. Comeram nossa plantação de rosas e começaram a morder as escadas. A única defesa é irriga-las. Já não se assustam com a fumaça nem com o veneno (MARTÍNEZ, 1969, p.179) ${ }^{6}$.

Vinculado à história tucumana, como vimos, esse fato romanesco confirma a afirmação de Chiampi (1980) sobre o Realismo Maravilhoso, segundo a qual, todo e qualquer elemento relacionado com o humano, ao ser considerado extraordinário ou quando escapa de uma explicação racional e do curso ordinário das coisas, recebe a conotação de milagre e passa a obter aceitação do indivíduo comum. A segunda atribuição, apontada pela estudiosa acerca dessa modalidade do Insólito,

6 Texto-fonte: "[...] - Somos sus únicos enemigos - dice el viejo, abrazado al irrigador -. Hemos entregado a los bomberos un plano de sus galerías, una lista de sus reinas y un mapa de sus nidos. Les hemos avisado que tienen campos de entrenamiento en Lules y una flota de tanques para tomar el poder. Nadie nos oye, nadie quiere creernos. Estamos desesperados. En la fuente del patio, las hormigas han instalado el cuartel general, los aeródromos y los parques de diversiones. Nos han comido los rosales y han empezado a morder las escaleras. La única defensa es irrigarlas. Ya no se asustan del humo ni del veneno. (MARTÍNEZ, 1969, p.179) 
refere-se a tudo o que é inumano e se produz pela intervenção dos seres naturais.

No romance em análise, o culto a um animal, praticado pelo pai de Bío, demonstra extraordinariedade. A provável morte do filho relaciona-se com a expressão russa que dá abertura ao romance - Knovz smovz ka pop - nesse contexto, a significar que todo mal será castigado:

'Castigo de Deus' - disse papai - por ficar na jogatina fazendo um papelão'. Como penitência, apalpou a burra e, para livrá-la de sua dor, encheu o chapéu com o leite passado. Esse foi o primeiro milagre do beato San Martín, cuja vassourinha invocou papai naquele momento: do céu recebeu a ordem para que me oferecesse o leite, e assim que o provei, fui surrupiado da morte. (MARTINEZ, 1969$, p.16 $)^{7}$

Ao salvar Bío com o leite da burra, o pai, grato pelo milagre, ajoelha-se e a denomina María Santísima. Toda vez que precisa ordenhar a quadrúpede, como forma de punição pelos pecados cometidos, tolera ser castigado com coices. Ao descrever a saga da família para livrar o recém-nascido da morte, o narrador enfatiza a relação inabitual entre o homem e o animal:

'Oh, Maria Santíssima', ele a chamava desde a área do pênalti, e a burra trotando em direção a ele com manhas de noiva: não se deixava tocar até que papai não lhe rendesse culto, ajoelhando-se e suportando os chutes de boas vindas. Aquele leite

7 Texto-fonte: "'Castigo de Dios' - dijo el papá -, por quedarme en la canchita haciendo un papelón.' En penitencia tanteó a la burra, y para descargarla del dolor llenó el sombrero con la leche atrasada. Ese fue el primer milagro del beato San Martín, cuya escobita invocó el papá en aquel momento: del cielo recibió la orden de que me ofrendara la leche, y apenas la probé, fui sonsacado de la muerte". (MARTINEZ, 1969, p.16) 
me engordou a carapaça e revigorou para sempre a minha flora intestinal. (MARTÍNEZ, 1969, p.17) ${ }^{8}$

As proibições e restrições sociais atingem Bío, educado para reprimir pensamentos que causem alguma excitação ou desejo, e cujo objetivo é não cometer "pecados". Ao atender as orientações que recebe das personagens femininas da família, atribui nomes e significados às coisas. A fim de dissimular sua curiosidade quanto ao sexo, confere tantas significações ao momento vivido, que pensa existir uma eternidade prazerosa e a ela se entrega. Ao término do ato sexual, retorna à realidade castradora, onde mãe, tias e avós impunham-lhe o comportamento que julgavam adequado à sociedade local:

Encontrei a vida rasteira que não se sabia viver, nem se apaixonar, nem dizer: 'Amorzinho, estou aqui, pega de mim tudo que você quiser porque não tenho coragem de negar-me'. E logo que vi a verdadeira vida bebendo a água das fontes nas praças, sem me preocupar com os micróbios nem com as pestes, mal a vi três dias seguidos de farra, sem pensar no sono nem no cansaço, e a ejacular dez vezes em uma única noite sem afligir-se pelas noites seguintes, mal vi a vida livrar-se do que dirão como um fogo de artifício, então o paraíso foi-me apagado de um golpe, demonstrou sua inutilidade e sua lerdeza [...] E assim, pois, senti-me viver, recobrei meus entornos e minhas origens e meus azedumes hereditários. (MARTINEZ, 1969, p.23) ${ }^{9}$

8 Texto-fonte: "'iHola, María Santísima!', la llamaba desde el área penal, y la burra se le acercaba trotando, con melindres de novia: no se dejaba tocar hasta que el papá no le rendía culto, arrodillándose y soportando las coces de bienvenida. Aquella leche me engordó el velamen y asoleó para siempre mi flora intestinal". (MARTINEZ, 1969, p.17)

9 Texto-fonte: "Hallé la vida rastrera que no sabía vivirse, ni enamorarse, ni decir: 'Amorcito, aquí estoy, tomá de mí todo lo que quieras porque no tengo el coraje de negarme'. Y apenas vi a la verdadera vida bebiendo el agua de los surtidores en las plazas, sin preocuparme por los microbios ni las pestes, apenas la vi tres días seguidos de 
Bío descreve detalhadamente sua experiência sexual e finaliza com a expressão "tive um dia de paraíso" (MARTINEZ, 1969, p.17) ${ }^{10}$. O termo "paraíso", que consta na compilação elaborada por Bernd (2007), sob a autoria de Henriete Karam (p.506-511), "designa um lugar de delícias, aprazível, edênico, apresentando correspondência tanto com o Éden [...] quanto com o céu" (p.506) e significações relativas ao espaço físico e ao estado da alma. A sensação que Bío experimenta atende à segunda condição, pois o local não é destacado, passa despercebido, diferentemente dos sentimentos que inundam o protagonista. Para Karam (2007), "a ideia de paraíso (de acordo com as culturas ameríndias) encontra-se representada no mito da terra sem mal" (p.507), lugar privilegiado e perfeito, onde espaço e tempo fazem com que o sujeito ascenda ao plano celestial e os deuses desçam ao mundo terreno.

Conforme Regina Zilberman (1994, p.12-34), durante muito tempo, descobridores, navegantes e cronistas acreditavam que o Jardim do Éden se encontrava na América. Após a chegada de portugueses e espanhóis em solo americano, as escritas correntes mencionavam um espaço rico em flora, fauna e, principalmente, minerais e pedras preciosas, verdadeiro paraíso material. É o caso de Américo Vespúcio (Apud ZILBERMAN, 1994), ao descrever as paisagens paradisíacas do Novo Mundo:

Esta terra é muito amena; cheia de inúmeras árvores verdes, e muito grandes, e nunca

jolgorio, sin pensar en el sueño ni en el cansancio, y eyacular diez veces en una sola noche sin afligirse por las noches siguientes, apenas vi a la vida zafarse del qué dirán como una caña voladora, entonces el paraíso se me borró de un saque, demostró su inutilidad y su torpeza. [...] Y así, pues, me sentí vivir, recobré mis alrededores y mis orígenes y mis vinagreras hereditarias. (MARTINEZ, 1969, p.23)

10 Texto-fonte: "tuve un día de paraíso" (MARTINEZ, 1969, p.17). 
perdem folha, e todas têm odores suavíssimos, e aromáticos, e produzem inúmeras frutas, e muitas delas boas ao gosto e saudáveis ao Corpo, e os campos produzem muita erva, e flores, e raízes muito suaves, e boas, que umas vezes me maravilha de odor suave de ervas, e das flores, e do sabor dessas frutas, e raízes, tanto que em mim pensava estar perto do Paraíso terrestre. (p.15)

Zilberman (1994) afirma que o imaginário da época dava significado e sucesso editorial ao texto de Vespúcio: "a América se populariza enquanto tem condições de ser o que os europeus esperam dela" (p.16). Criava-se e recriava-se o mito do Paraíso, propagado até o século XVII, através da literatura que o difundia no Velho Continente. Relocalizava-se a concepção do Éden para conceber a ressignificação dada à América do Sul, quando, durante a colonização do continente, a natureza exuberante encontrada pelos exploradores europeus "atraía, porque podia ser explorada e facultava o enriquecimento de seus ocupantes" (ZILBERMAN, 1994, p.33).

Sagrado (MARTíNEZ, 1969) veicula a denominação de Tucumán como Jardín de la República, um registro do colonizador já reterritorializado, a partir de suas heranças e bens simbólicos, no momento em que a vegetação vasta e diversa da cidade e seus arredores teria impressionado os espanhóis. O designativo, contemplado por Martínez, ainda abrange a canção Al Jardín de la República, composição de Virgilio Carmona cujo fragmento - "Para as outras, não; pras do norte, sim; para as de Simoca, minhas ânsias loucas de estar ali"11 - entra de acordo com o que afirma Canclini (2003) sobre a reterritorialização:

11 Texto-fonte: "[...] Para las otras no, pa' las del norte si, para las de Simoca, mis ansias locas de estar alli". 
Nos intercâmbios da simbologia com os circuitos internacionais de comunicação, com as indústrias culturais e as migrações, não desaparecem as perguntas pela identidade e pelo nacional, pela defesa da soberania, pela desigual apropriação do saber e da arte. Não se apagam os conflitos, como pretende o pós-modernismo neoconservador. Colocam-se em outro registro, multifocal e mais tolerante, repensa-se a autonomia de cada cultura - às vezes - com menores riscos fundamentalistas. (p.326)

Registrada de outra forma em Sagrado (MARTíNEZ, 1699), a imagem fixada naquelas escritas dos exploradores europeus se reterritorializa: ao encontrar Brigi, Bío tem acesso a sensações que - levam a inúmeras possibilidades de chegar ao paraíso, em seu caso, em uma concepção mais mundana do que celestial. Processos de hibridação como esse, segundo Canclini (2003), enfrentam resistências por gerarem insegurança nas culturas e conspirarem contra sua autoestima etnocêntrica. Torna-se "necessário registrar aquilo que, nos entrecruzamentos, permanece diferente" (p.XXXIII).

A propósito, Carmen Perilli (2010), em "La patria entre naranjos y cañaverales. Tucumán y el primer centenario", menciona curiosos e fascinados cartógrafos que buscavam seduzir seus receptores através do imaginário território paradisíaco, em que selva e montanhas conviviam, onde habitavam o índio livre e o criollo submisso. A autora destaca a literatura elitista, voltada à cultura hispânico-europeia, na qual se apresenta um trabalhador que se satisfaz servindo às imposições do patrão de forma harmoniosa e a elas adaptado. A estreita vinculação entre família, cultura e poder preservava e difundia os valores considerados patrimônio local, os 
donos dos engenhos de açúcar ocupavam os postos políticos na província e na capital tucumanas.

Juan B. Terán, mencionado por Perilli (2010), proporciona argumentos geográficos, históricos e simbólicos sobre o espaço tucumano:

Descreve o norte argentino como uma extensa zona povoada, constituída pelas províncias de Tucumán, Santiago del Estero, Salta, Catamarca y Jujuy que, em sua totalidade, reúne, mais de um milhão de habitantes. O centro 'de atração natural' desta região é a cidade de San Miguel de Tucumán 'terra de encontro' de civilizações que emerge como urbe de 'vida industrial e agrícola ativa e inteligente' e com um capital educativo apreciável. (TERÁN, Apud PERILLI, 2010) ${ }^{12}$

Os argumentos de Terán enfatizam a influência hispânica que consolidou uma configuração sociocultural marcada pelo ideário cristão e, portanto, repressor no que concerne à sexualidade. A região tucumana apresenta "fenômenos próprios", ainda que, durante um longo período, sua história tenha ficado à margem, pois se tratava do interior argentino, ocupando posição de sombra da capital, Buenos Aires. Os enlaces políticos, econômicos, sociais e o crescimento dos engenhos de açúcar fizeram com que a província de Tucumán se destacasse no cenário nacional; o movimento de resistência e a nostalgia do passado não impediu a projeção para o futuro.

12 Texto-fonte: "Describe el Norte como una extensa zona poblada, constituida por las provincias de Tucumán, Santiago del Estero, Salta, Catamarca y Jujuy que, en su totalidad, reúnen más de un millón de habitantes. El centro 'de atracción natural' de esta región es la ciudad de San Miguel de Tucumán 'tierra de encuentro' de civilizaciones que emerge como urbe de 'vida industrial y agrícola activa e inteligente' y con un apreciable capital educativo" (TERÁN, Apud PERILLI, 2010). 
Catolicismo e espiritualismo passam a representar as bandeiras contra ideias laicas, sustentadas pelo socialismo e pelo radicalismo (formação política nacional), considerados "bárbaros" pela sociedade dominante. Perilli (2010) conclui que predomina a concepção de cultura superior baseada no espiritual sem causar prejuízo ao desenvolvimento científico: classificar, ordenar. A tentativa consiste em inventar uma Tucumán que, no decorrer do tempo, progrida, relacionando-se com o pensamento de Canclini (2003) sobre a vigência dos perfis nacionais em algumas áreas de consumo, sobretudo nos campos em que cada sociedade dispõe de ofertas próprias.

Segundo declara Martínez (1997), em entrevista a César Güemes publicada no periódico La Jornada, o país era a sexta potência industrial do mundo, superava a França no número de automóveis e o Japão, em telefones. Especialistas afirmavam que, até o final do século $\mathrm{XX}$, seria estabelecida uma grande competição com os Estados Unidos, o que nunca aconteceu devido às crises econômicas e às ditaduras, mas a imagem de potência, construída e enraizada, permanece até a atualidade.

O ficcionista argentino compara o país a Eva Perón que, embalsamada, não sofre deterioração, mas também não muda, não evolui. No que diz respeito à produção literária, continua a valorizar a escrita nos velhos moldes europeus. O escritor afirma que, embora a crítica nacional reconheça a literatura do Rio da Prata, a sua escrita é tributária da incaica, pois vem da região Norte do país, e menciona que sua esposa, a venezuelana Susana Rotker, algumas vezes, quando pegava táxis em Buenos Aires, era questionada pelos motoristas se era sul-americana. Nessa 
perspectiva, compactuamos com a conclusão de Canclini (2003) ao reconhecer que a hibridação é um conjunto de processos, muitas vezes conflitivos, no qual "os cruzamentos intensos e a instabilidade das tradições, bases da abertura valorativa, podem ser também em condições de competição profissional - fonte de preconceitos e confrontos" (p.326).

Os romances martinezianos objetivam demonstrar até que ponto podem ser considerados sul-americanos. Nesse sentido, Sagrado (MARTíNEZ, 1969) apresenta a origem de Tucumán nas entrelinhas e, para entendê-la, buscamos apoio em um dos seus primeiros historiadores, Arsenio Granillo, que escreveu, em 1870, Província de Tucumán. Publicado em 1872, o estudo visava mostrar diversas possibilidades de que dispunha a província e apresentava riquezas aos imigrantes (estrangeiros) que vislumbrassem a possibilidade de explorar seus recursos. Granillo (1872) aborda, desde o descobrimento, a etimologia do nome dado à região, seus aspectos geográficos e, ainda, o comportamento da sociedade tucumana.

Segundo Granillo (1872), o primeiro espanhol a adentrar em terras tucumanas foi Don Diego Rojas que, em 1543, tomou conta do Valle de Calchaquí. Após a invasão, matança e aprisionamento dos índios, o local passou a ser denominado Barco de Ávila. Somente em 1565, fundou-se San Miguel de Tucumán, até então, um distrito de Santiago del Estero, tardando cento e vinte anos para que atingisse a atual extensão territorial. O nome dado à província tucumana provém do cacique inca Tucman, líder de muito prestígio na região, e de ahaho que, na língua dos calchiquíes, significa povo, logo, povo de Tucman. Embora chamada de Nueva Andalucía pelos conquistadores, o nome do inca, mesmo que alterado, prevaleceu: 
Hoje o que se conhece com o nome de Tucumán é unicamente o território compreendido entre as Províncias de Santiago del Estero, Catamarca e Salta, que tem pouco mais, ou menos, cinquenta léguas de sul a norte, e quarenta de nascente a poente (GRANILLO, 1872, p.6) ${ }^{13}$.

Podemos traçar um paralelo entre o protagonista do romance martineziano, Bío, e o líder inca, Tucman, pois, relacionados diretamente com seu lugar de origem, defendem a terra, independente dos males que possam recair sobre eles. Tucman enfrentou a colonização espanhola, a imposição de costumes e cultura. Bío, por sua vez, contesta as exigências sociais, culturais e religiosas; no entanto, passa parte de sua vida atendendo às tradições. Ao perceber o domínio que a família/sociedade exercia sobre suas escolhas, afasta-se da cidade natal, mas sempre busca uma forma de retornar. Tanto em Sagrado (MARTÍNEZ, 1969) como na história de Tucumán, a vida do sujeito tucumano vincula-se ao mundo agrícola:

a agricultura é uma indústria que estreita mais e mais os vínculos sociais do homem, pelo muito que solicita o contato contínuo com os demais; e acostumando-o a vencer com o trabalho os inconvenientes que lhe propõe a natureza, faz com que se habitue à vida laboriosa, manancial inesgotável da riqueza e moralidade [...] 0 agricultor exercita suas forças musculares nos labores da terra, sem que suas paixões se exaltem. (GRANILLO, 1872, p.129) ${ }^{14}$

13 Texto-fonte: "Hoy lo que se conoce con el nombre de Tucuman, es unicamente el territorio comprendido entre las Provincias de Santiago del Estero, Catamarca y Salta, que tendrá poco mas ó menos cincuenta leguas de Sud á Norte y cuarenta de Naciente a Poniente" (GRANILLO, 1872, p.6)

14 Texto-fonte: "La agricultura es una industria que estrecha más y más los vínculos sociales del hombre, por cuanto reclama el contacto continuo con los demás; y 
Segundo o historiador, o trabalho com a terra é capaz de "domesticar" o ser humano, faz com que aprenda a lidar com suas instabilidades e decepções; o sucesso e o progresso dependeriam das tradições sociais e religiosas pré-estabelecidas. Granillo (1872) afirma que o trabalhador tucumano deveria fé e obediência ao catolicismo (hispânico-europeu). Por sua vez, a personagem principal do romance em análise depara-se diversas vezes com situações que exigem determinado posicionamento. Seguir as tradições judaico-cristãs seria a condição primordial para que alcançasse o êxito social e familiar. Em certa passagem da narrativa, ao descer as escadas do corredor que levava os homens até a chamada "entrada do paraíso", nota que

a cara da Brigi era invisível por causa do sacro resplendor que lhe passava por adiante, o nariz estava no escuro e adiantada em direção do trono e as dominações da Passagem. Ela sorriu para mim, virgem e madonna, pilar, mercedes e pompeia, mas a gritaria dos tucanos, dos cachorros e das rolinhas que chegavam abraçadas ao paraíso cortou-Ihe $o$ sorriso. Vi também ao papai brigando com o Gosi [...]. (MARTÍNEZ, 1969, p.22) ${ }^{15}$

Bío sente-se seduzido, mas não pode ceder; a sociedade não aprova a sua relação com madonna, uma prostituta. A gritaria dos animais, vinculados aos protestos e reprovações da comunidade acostumbrándolo a vencer con el trabajo constante los inconvenientes que le opone la rebelde naturaleza, le hace habituarse a la vida laboriosa, manantial inagotable de riqueza y moralidad [...] El agricultor ejercita sus fuerzas musculares en los laboríos de la tierra, sin que sus pasiones se exalten" (GRANILLO, 1872, p.129).

15 Texto-fonte: "La cara de la Brigi era invisible a causa del sacro resplandor que se le paseaba por delante, la nariz estaba a oscuras y adelantada hacia los tronos y las dominaciones del Pasaje. Ella me sonrió, virgen y madonna, pilar, mercedes y pompeya, pero el griterío de los tucanes, de los perros y de las torcazas que llegaban abrazados al paraíso le cortó la sonrisa. Vi también al papá peleándose con el Gosi" [...]. (MARTÍNEZ, 1969, p.22) 
tradicional faz com que o protagonista imagine "Saladino levantar as muralhas de Jerusalém, as tribos diaguitas remontarem as cataratas do rio Salí no princípio dos tempos" (MARTíNEZ, 1969, p.23) ${ }^{16}$. Se os bens simbólicos hibridizados reconfiguram uma condição outra, elaborada nos entrecruzamentos e intercâmbios culturais, a fim de não se deixar levar pela sedutora Brigi, a personagem principal relaciona a cidade bíblica aos povos indígenas independentes (conquistados pelo império incaico e a ocuparem o Valle Calchaquíes, situado nos atuais territórios argentinos de Jujuy, Salta e Tucumán), bem como ao curso das águas que, além das duas últimas províncias referidas, banham Catamarca, Córdoba e Santiago del Estero.

Contudo, o desmascaramento das opiniões sociais e convencionais do narrador-personagem está presente nos silêncios ou em momentos destinados a divagar e ter as próprias impressões do mundo. Quando se deita para dormir ou em "isolamento mental", demonstra seus pensamentos frente às imposições sociais e religiosas. Às vezes, chega a levantar hipóteses sobre o que realmente faria se fosse livre; em outras, narra fatos só realizados em sua mente, para se sentir solto e "dono" de sua vida. A revolta contra as designações da sociedade revelam-se ao mencionar todos os males que gostaria de praticar como resposta a sua infância castrada por convenções. As experiências, os questionamentos próprios de sua idade, os castigos e observações perante imposições de seus familiares são repletos de contestações:

Tudo siga pela ordem, conforme a fila indiana e sua cronologia. Que chegue em ordem o conto 16 Texto-fonte: "vi a Saladino alzar las murallas de Jerusalén, a las tribus diaguitas remontar las cataratas del río Sali en el principio de los tiempos". (MARTíNEZ, 1969, p.23) 
da minha infância despedaçada pela opinião pública, cevada na burguesia pelos meus entornos de bolinhos fritos e tardes de chá, afelpada pelo pressentimento da Brigi que ai, ia tirar-me a pureza como uma venda suja. Não faça aquilo, a noção do bem se encarnou contra a minha pobre pessoa em idade escolar, passeou-me como gravatinhas borboletas e camisas engomadas diante das minhas tias genealógicas, a tias literatas que me barbearam com um vidro toda a vontade de viver. Brotei do vidro e das contusões feridíssimo de morte: ia levantar as saias das tias clérigos e me mordia a língua, a jogar um sapo morto no decote das tias deputadas e o nó do coração me freava, ia quebrar os pratos da casa, estraçalhar os colchões, despedaçar a honra imaculada de minhas primas e enteadas e robustas avós, mas a fúria e o fogo da minha espécie se me havia dormido, gastava sua paixão nos limbos de outras vidas mais dignas. (MARTÍNEZ, 1969, p.24) ${ }^{17}$

Após sua revolta, a personagem principal manifesta-se em monólogo interior, expõe as possíveis práticas que (certamente) seriam repreendidas pelas tias, ou seja, pelo primeiro grupo da sociedade na qual está inserida. Bío expressa seu desacordo com as determinações/imposições familiares praticadas pelas

17 Texto-fonte: "Todo vaya por orden, según su fila india y su cronología. Que llegue por orden el cuento de mi infancia destrozada por la opinión pública, cebada en la burguesía por mis alrededores de buñuelo y tardes de té, afelpada por el presentimiento de la Brigi que ay, iba a quitarme la pureza como una venda sucia. No hagas aquello, la noción del bien se encarnizó contra mi pobre persona en edad escolar, me paseó como moños y camisas almidonadas delante de mis tías genealógicas, las tías literatas que me afeitaron con un vidrio todas las ganas de vivir. Broté del vidrio y de las magulladuras heridísimo de muerte: iba a levantarle las polleras a las tías clérigos y me mordía la lengua, a echar un sapo muerto en el escote de las tías diputadas y el nudo del corazón me sofrenaba; iba a romper los platos de la casa, a destripar los colchones, a rasgar el honor sin tacha de mis primas y entenadas y robustas abuelas, pero la furia y el fuego de mi especie se me había dormido, gastaba su pasión en los limbos de otras vidas más dignas". (MARTÍNEZ, 1969, p.24) 
personagens femininas de sua família, todas fundamentadas na tradição tucumana e com a justificativa de que somente assim, um dia, seria alguém de respeito e reconhecido. Em seu pensamento, elucida que não passam de conclusões pensadas, porém, nunca executadas. Depois da conturbação mental, rende-se às convenções e declara: "o certo é que eu empreendia minha viagem de volta, terminava por cair no sono com uma invocação ao anjo da guarda" (MARTÍNEZ, 1969, p.24) ${ }^{18}$.

Como forma de clemência aos pensamentos indômitos, Bío retorna, aparentemente submisso a determinações às quais às vezes se mostra contrário, permitindo destacar os conflitos de uma sociedade impregnada de crenças e mitos. Sagrado (MARTíNEZ, 1969) não consiste em um documento histórico, porém evidencia as condições socioculturais e religiosas da submissão com a qual o protagonista constantemente se defronta, pois até o seu pensamento é vigiado. Ele se entrega ao conforto dos desejos e realiza suas vontades mentalmente, mas ao fim e ao cabo, retorna ao seu mundo:

Não nos interessava a realidade que cabe nas palavras, a que está instalada nos escaninhos do abecedário; pretendíamos uma outra cujo horizonte fosse uma ameaça, um cemitério, uma sístole, um buraco, um porém, um clarear, destelhar, quebrar os olhos, um bobo, um ápice, um inteiramente. Amávamos, é certo, todos os fios soltos do universo, sem saber com que cola se grudavam nem qual xadrez jogavam com a gente [...] Desfigurávamos as aparências, ateávamos fogo nas cadeiras para ver se entre tanta algazarra havia

18 Texto-fonte: "lo cierto es que yo emprendía mi viaje de vuelta, terminaba por dormirme con una invocación al ángel de la guardia". (MARTínEZ, 1969, p.24) 
um interstício onde nos encontrássemos inteiros, uma cripta que nos tornasse libres e donos de dizer: 'Isto que conto é o que acontece, com suas vírgulas e pontos, sem traições, apesar da música das palavras que nunca encaixa na música do que acontece'. (MARTíNEZ, 1969, p.132) ${ }^{19}$

Segundo o aporte teórico utilizado no presente estudo, mostram-se bastante significativas a origem e a formação do povo sul-americano, especialmente tucumano, na elaboração do romance Sagrado (MARTÍNEZ, 1969), repleto de efeitos emotivos, ora neutralizados, ora negados no Realismo Maravilhoso. Nessa obra literária, as descrições fazem o papel de convencer e/ou questionar quanto às mudanças radicais sofridas por Bío, que não consegue alcançar a metamorfose social, cultural e religiosa, em função dos desarranjos causais, aos quais, de alguma forma, se sente atrelado.

Atentamos, pois, para marcas representativas da comunidade tucumana, baseada em jogos de influências familiares, sociais e tradicionais, pois Martínez reelabora, por intermédio da ficção, não apenas a pluralidade cultural da sua cidade natal, mas também questões implicadas na temática da América em redescobrimento, uma preocupação desencadeada a partir da Revolução Cubana de 1959. Conforme Irlemar Chiampi (1980), essa imagem marca o mundo imaginário dos escritores que mantêm vivos e/ou como

19 Texto-fonte: "No nos interesaba la realidad que cabe en las palabras, la que está instalada en las casillas del abecedario; pretendíamos una cuyo horizonte fuera una amenaza, un cementerio, un sístole, un ojal, un aunque, un clarear, destellar, quebrar los ojos, un tonto, un ápice, un enteramente. Amábamos, es cierto, todos los hilos sueltos del universo, sin saber con qué engrudo se pegaban ni a qué ajedrez jugaban con nosotros [...] Desfigurábamos las apariencias, les echábamos fuego en las caderas para ver si entre tanto zafarrancho había un intersticio donde nos encontráramos enteros, una cripta que nos volviera libres y dueños de decir: 'Esto que cuento es lo que pasa, con sus comas y puntos, sin traiciones, a pesar de la música de las palabras que nunca encaja en la música de lo que pasa'"; (MARTINEZ, 1969, p.132) 
fontes de inspiração as lendas, os mitos e as crenças de suas respectivas épocas, regiões, nações.

O universo ficcional elaborado na escrita martineziana naturaliza os eventos insólitos, associando o contexto histórico por ele referido às experiências vividas pelo protagonista que, na maior parte das vezes, se submete a determinações impostas. Cabe retomar o binômio desterritorialização/reterritorialização, pois como um dos processos para a hibridação, explica a mobilidade, as negociações e as fusões/ interações/interseções que permeiam Bío e a cidade argentina como um elemento único e singular, a fim de reafirmar a identidade e os bens simbólicos ressignificados. O espaço geográfico e o espaço biográfico de Martínez imbricam-se ao seu protagonista, assinalando a reconstrução e a constituição do espaço híbrido assim representado.

Comoveremos, a fábula ou história de Sagrado (MARTÍNEZ, 1969) realiza determinada espécie de condensação entre o protagonista e a cidade de Tucumán, no entanto, quebrada por mecanismos que promovem a alteridade em sua trama ou discurso. Assim, os diversos narradores desse primeiro romance martineziano - Bío, Andrés e Boni - contestam imposições sociopolíticas, assinalam diversidades étnico-culturais e ironizam práticas religiosas judaicocristãs, confrontando-as a transgressões que podem até merecer castigo, mas não deixam de ocorrer. Já a figuração das personagens contribui para com sua construção híbrida, ao mesmo tempo em que a composição dos sujeitos também auxilia a estabelecer a alteridade expressa na linguagem martineziana, através de um "eu" que problematiza a ficção e o que é verossímil, a partir de olhares questionadores, bem como da inserção de outros gêneros, linguagens e temporalidades no discurso romanesco. 


\section{REFERÊNCIAS}

BERND, Zilá (2007). "Recém-nascido". In: BERND, Zilá. Dicionário de figuras e mitos literários das Américas. Porto Alegre: Editora da Universidade. p.547-551. CAMPI, Daniel (2003). "Azúcar y trabajo. Coacción y mercado laboral en Tucumán". Población \& sociedad, (10-11). 250-252. In http://dialnet.unirioja.es/ servlet/articulo?codigo=326581 Acesso em 19.0ut.2015.

CANCLINI, Néstor García (2003). Culturas híbridas: estratégias para sair da modernidade. Heloísa Pezza Cintrão \& Ana Regina Lessa (Trad.)2. ed. Gêneses. 4.ed. São Paulo: Editora da USP.

CARMONA, Virgílio (1968). "Al Jardín de la República". In Con sabor a Mercedes Sosa. Buenos Aires: Philips. Faixa 6.

CHEVALIER, Jean (1994). Dicionário de símbolos: mitos, sonhos, costumes, gestos, formas, figuras, cores, números. 8.ed. Rio de Janeiro: José Olympio.

CHIAMPI, Irlemar (1980). O realismo maravilhoso. São Paulo: Perspectiva.

CUNHA, Rubelise da (2007). "Trickster" In: BERND, Zilá. Dicionário de figuras e mitos literários das Américas. Porto Alegre: Editora da Universidade. p.641-647. ESTEVES, Antonio R.; FIGUEIREDO, Eurídice (2010). "O realismo mágico e o realismo maravilhoso". In: FIGUEIREDO, Eurídice (Orgs.). Conceitos de literatura e cultura. Juiz de Fora, Editora da UFJF. p.393-414.

GRANILLO, Arsenio (1872). Provincia de Tucumán. Tucumán, Imprenta de la Razón. GÜEMES, César (1997). "Argentina, en el engaño de creerse en Europa y no en América Latina: Eloy Martínez", La Jornada, México, 19 de oct 1997. In http:// www.jornada.unam.mx/1997/oct97/971019/eloy.html Acesso em: 20.Nov.2014. HANCIAU, Nubia Jacques (2007). "Feiticeiria". In: BERND, Zilá. Dicionário de figuras e mitos literários das Américas. Porto Alegre: Editora da Universidade. p.282-288.

KARAM, Henriete (2007). "Paraíso". In: BERND, Zilá. Dicionário de figuras e mitos literários das Américas. Porto Alegre: Editora da Universidade. p.506-511.

LAROCHE, Maximilien (2007). "Zombi". In: BERND, Zilá. Dicionário de figuras e mitos literários das Américas. Porto Alegre: Editora da Universidade. p.687-692. MARTÍNEZ, Tomás Eloy (1969). Sagrado. Buenos Aires: Editorial Sudamericana. 
PERILLI, Carmen (2010). “La patria entre naranjos y cañaverales. Tucumán y el primer centenario". Revista Pilquen, Universidad Nacional del Comahue, 12(12), 1-9.

. "Tomás Eloy Martínez, el gran peronólogo". In La Gaceta. In http:// www.lagaceta.com.ar/nota/634927/la-gaceta-literaria/tomas-eloy-martinezgran-peronologo.html Acesso em: 22.Dez.2015.

ZILBERMAN, Regina (1994). "Natureza, lucro e paraíso". In: . A terra em que nasceste: imagens do Brasil na literatura. Porto Alegre: Editora da UFRGS. p.12-34. 


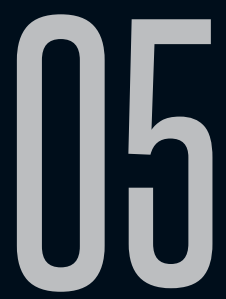

\section{MERLIM, DE ROBERT DE BORON, E O TEXTO RELIGIOSO}

Mariany Camilo Nabarrete (UEM) Fábio Lucas Pierini (UEM)

Recebido em 23 set 2018. Mariany Camilo Nabarrete é Acadêmica do programa Aprovado em 15 fev 2019. de Pós-graduação em Letras, na Área de concentração em Literatura, pela Universidade Estadual de Maringá, linha de pesquisa em literatura e historicidade, nos estudos da Literatura Fantástica.

Fábio Lucas Pierini é Doutor em Estudos linguísticos, literários e tradutológicos pela FFLCH-USP com pósdoutorado em Estudos Literários pela Unesp FCL/CAr. Professor na UEM (Maringá-PR), atuando nos cursos de Secretáriado Exacutivo Trilíngue e Letras na área de Língua e Literatura Francesas, leciona e orienta a respeito de narrativa fantástica no Programa de PósGraduação em Letras e no Programa de Iniciação Científica. Participa do CT Anpoll Vertentes do Insólito Ficcional e do Grupo CNPq Estudos de Literatura e cultura da Belle Époque: LABELLE.

Resumo: Este artigo pretende identificar o processo de cristianização do personagem protagonista da obra medieval Merlim, além de averiguar como e porque o autor, Robert de Boron, utiliza a intertextualidade, mais especificamente a estilização, para criar sua narrativa. As obras medievais, segundo estudiosos, possuem um caráter formador, foram criadas com o 
intuito de adequar uma população a um determinado regime político e religioso, logo, um estudo sobre o personagem Merlim descrito por Robert de Boron se faz importante para que se possa compreender a necessidade da literatura na Idade Média, bem como para desvendar uma razão que justifique a presença do personagem em obras posteriores. Para tanto, a análise do livro Merlim, de Robert de Boron, pauta-se nas teorias de intertextualidade e hipertextualidade de Gérard Genette (2010), assim como na teoria de paródia, paráfrase e intertextualidade defendida por Affonso Sant'Anna (2003). Com isso, nota-se que a modificação do personagem medieval, realizada por Boron por meio da intertextualidade, é regida pela intencionalidade do autor em catequizar povos pagãos, afinal, ao recriar um personagem da cultura Celta com características cristãs, próximas às de Jesus Cristo, o autor conduz os povos para longe do pecado, como exortado pela Igreja na época.

Palavras-chave: Merlim; Estilização; Intertextualidade; Literatura francesa.

Résumé: Cet article a l'objectif d'identifier le processus de la christianisation du personnage médiéval Merlin, en plus il a l'objectif de découvrir comment l'auteur Robert de Boron se sert de l'intertextualité, plus spécifiquement de la stylisation pour créer son récit. Selon les spécialistes les œuvres médiévales possèdent un caractère d'apprentissage, elles ont été créées avec l'intention d'adapter une population à un certain régime politique et religieux, donc il y a la besoin d'étudier le personnage Merlin décrit par Robert de Boron, pour que l'on puisse comprendre les caractéristiques de la littérature du Moyen Âge, aussi bien que pour démasquer la présence du personnage dans les œuvres qui ont été écrites antérieurement. Ainsi, l'analyse du livre Merlin de Robert de Boron serat-elle examinée d'après les théories d'intertextualité et hypertextualité développées par Gérard Genette (2010), aussi bien que les concepts de parodie, 
de paraphrase et d'intertextualité chez Affonso Sant'Anna (2003). Avec ces théories on observe que la modification du personnage médiéval créé par Boron est dirigée par l'intention de l'auteur $d$ ' instruire les païens en créant un personnage celtique avec des caractéristiques chrétiennes, près de celles de Jésus Christ, afin de éloigner les gens du péché pèche, selon les principes dictés par l'Église à ce moment-là.

Mots-clé: Merlin; Stylisation; Intertextualité; Littérature française.

\section{INTRODUÇÃO}

Merlim, também conhecido pelo nome de Myrddin, é um personagem mítico da cultura Celta. Um druida por vezes descrito como louco, profeta ou selvagem, que se torna o protetor do Rei Artur na lenda do ciclo arturiano. Por séculos, o personagem rondou as lendas orais e as obras escritas, apesar de muitas passagens com histórias e características do personagem terem sido perdidas, modificadas, destruídas e até mesmo censuradas durante mais de mil anos, as alterações realizadas nas histórias do profeta não mudaram o senso comum de que Merlim pode ter sido fruto de um personagem histórico da Idade Média.

No processo literário deste período, as histórias relacionavamse, em grande medida, com histórias bíblicas e/ou com os clássicos, da mesma forma, a lenda de Merlim também recebeu essas influências, logo, sua relação, em alguns textos pequena, em outras maiores como em Boron, com os textos bíblicos fizeram com que sua literatura tomasse o seu lugar no cenário mundial.

Na sociedade medieval, os documentos escritos estiveram sob responsabilidade da Igreja, pois eles eram replicados pelo trabalho 
dos copistas, monges retidos nos interiores de seus mosteiros. As histórias, neste momento, deixaram de ser orais e passaram a ser fixadas em papéis para que os responsáveis pelas transmissões das histórias não as alterassem. Contudo, as lendas orais registradas passavam pelo crivo de seus copistas e da Igreja, sendo, por vezes, cortadas, modificadas e até mesmo suprimidas da história. Aos poucos, a instituição religiosa deixou de influenciar diretamente na produção literária e os temas passaram de hagiografias e de livros de linhagens para relatos de fatos históricos e novelas de cavalaria.

Algumas modificações realizadas durante os séculos fizeram com que o personagem histórico se tornasse diferente do ficcional, tornando-o mais próximo aos costumes da sociedade leitora. Dentre as alterações realizadas na história do personagem, aventuras, romances e magia foram acrescentadas nos textos. Por isso, o Merlim histórico passou a ser ficcional, personificando os grandes magos da época: um vidente, um profeta inspirado, um astrólogo, um alquimista, um especialista em magia natural e um adepto a cosmologia. Entretanto, diferentemente dos grandes magos encontrados nos textos bíblicos, Merlim tinha a vantagem de não precisar convocar demônios para realizar sua mágica, isto pois, segundo Boron, além de ser cristão, ele era filho do próprio diabo.

Uma ligação clara entre a personagem histórica de Merlin e as lendas que gravitam ao seu redor é quase inexistente, por isso, podemos admitir pouco sobre a ligação entre Merlim histórico e o ficcional. Como já mencionado, a história do personagem sobreviveu durante anos pela tradição oral, essa que era modificada, alterada e incrementada de acordo com a necessidade do orador, ao passarem 
para o registro escrito ela se tornou mais rígida e restrita, mas ainda assim mantendo as modificações realizadas até o momento.

Muitos escritos foram perdidos por completo ou mesmo tiveram algumas de suas partes perdidas, o que fez com que não tenhamos acesso ao texto na íntegra. Após séculos de existência, as histórias viraram lendas permeadas por referências aos antigos costumes e ao advento da religião Católica. Dessa maneira, em toda a narrativa de Boron, Merlim passa a ser relacionado aos seus poderes, haja vista que a todo momento o protagonista lembra ao leitor e aos que estão à sua volta sobre sua capacidade de conhecer o passado e o futuro, dom (ou poder) justificado tanto por seu pai demoníaco, quanto pela fé e devoção de sua mãe a Deus. Boron também muda a denominação de Merlim de mago para profeta ou adivinho, aproximando-o à Igreja e à religiosidade e o afastando da magia.

Nesse sentido, para a pesquisadora Lawrence-Mathers (2012), o Merlim histórico não foi muito além de uma figura do folclore ou da criação de uma tradição popular, ele representa a vanguarda da ciência medieval e seus poderes eram convincentemente reais para as pessoas da época, ou seja, os artifícios e as profecias de Merlim, que parecem tão fantásticas, se não absurdas para um público moderno, foram levadas a sério pela sociedade medieval.

Ainda segundo a pesquisadora, o Merlim profeta e mago torna-se convincente como uma figura histórica, assim como o seu poder, advindo de sua habilidade de conhecer e ler os astros, essa legitimidade faz com que ele seja comparado em vários momentos com os profetas bíblicos. 
Merlim causou um grande impacto na Europa Medieval. Como uma figura histórica, ele reuniu elementos que têm como temachave a magia e a política. Seus poderes, assim como sua existência, permaneceram por séculos. Além disso, a personagem de Boron foi aceita como real e existente por explicar e exemplificar as magias praticadas até o seu surgimento, isto é, no decorrer da história manteve-se o esclarecimento das práticas comuns da época.

Apesar da maneira como sua narrativa foi disseminada por anos, ou seja, sob a influência tanto da Igreja quanto da política, o personagem manteve sua imagem ligada ao povo e à cultura da época. Segundo Ardrey (2010), essa relação se comprova devido às dificuldades que os autores e pesquisadores enfrentaram ao escreverem sobre Merlim, afinal não encontravam uma versão autorizada e histórica que fosse verdadeira, mesmo que modificada.

Nas buscas realizadas pelos historiadores, afirma Ardrey (2010), percebe-se que a mais antiga menção do nome Merlim vem do galês. Porém, acredita-se ainda que o personagem histórico que inspirou a criação do mago auxiliador tenha sido Myrddin Wyllt, especula-se também que ele seja uma fusão entre um personagem lendário celta e um chefe de um clã supostamente chamado de Myrddin. Além disso, segundo lendas celtas, o Merlim histórico teria sido uma divindade druida ligada a rituais sazonais, o que motivou de certa forma a imagem de um homem selvagem, astrólogo, adivinho e mago.

O personagem ficcional, por sua vez, foi modificado, principalmente, em relação à sua origem. A real história pode ter sido subjugada pelas informações que o governo ou a igreja, poderes 
que se misturavam na Idade Média, mandavam ou permitiam. Exemplo disso é o que Lawrence-Mathers (2012) salienta, haja vista que, para a autora, o fato de Merlim ter uma mãe solteira era um problema para as reservas morais, sendo amplamente debatido por teólogos que se preocupavam com a recepção da sociedade, essa preocupação fez com que a história fosse abrandada e que concepção fora do matrimônio não fosse tido como uma escolha. Ainda assim, o poder de patronos e cortesãos ligados a Merlim fez com que a sua magia, as suas palavras, assim como a sua história se espalhassem rapidamente entre os historiadores monásticos.

Mesmo tendo sua origem modificada nos registros históricos e literários, a imagem de Merlim ligada ao poder sobrenatural não prejudicou a história e a reputação da Europa na Idade Média. De acordo com Lawrence-Mathers (2012), os leitores medievais consideravam alguns pontos da história de Merlim real, como a sua origem escandalosa, sendo fruto da sedução de uma mulher inocente e pertencente à realeza por um íncubo, para abrandar em alguma medida a promiscuidade encontrada na sociedade da época. Outro ponto defendido pela pesquisadora como real para os leitores foi a caça de Merlim quando criança, ato exigido como sacrifício de sangue por uma corte de sábios que temiam por suas vidas.

As magias realizadas pela personagem ficcional, em alguns momentos, são neutras, sem relação com a moralidade vigente na época. Segundo estudiosos, essa neutralidade se dava, provavelmente, graças à ambiguidade relacionada à dualidade moral dos aristocratas medievais, os quais eram, de maneira concomitante, cavaleiros, cavalheirescos e assassinos implacáveis. 
Ademais, a magia não era tão questionada pelos religiosos, já que Merlim era considerado um cristão logo após sua cristianização. Ele, diferentemente de outros personagens descritos em livros históricos e na Bíblia, recusou a aceitar uma posição oficial de consolador real ou conselheiro político, pois preferia viver longe da corte e em locais silenciosos.

Estudiosos da Idade Média defendem que Merlim foi um cristão, que defendeu seus dons e sua fé, nunca os relacionando ao dinheiro ou favores. Ainda sobre as magias, Lawrence-Mathers (2012) esclarece que elas foram resgatadas dos antigos para uma nova estrutura cristã, justificando a magia pelos atos divinos, transformando o personagem no responsável por esse resgate.

Ao longo da Idade Média, a magia não era algo estranho, era, em alguns casos, considerada real, assim como a existência de demônios. Por século, na Idade Média, a magia era realizada por intermédio de demônios, motivando uma maior hostilidade em relação ao cristianismo, fazendo com que a presença das bruxas fosse tida como ameaçadora para a religião. Como toda e qualquer menção de bruxaria de modo positivo não era tido como normal, supõe-se uma facilidade maior em encontrar resquícios de relatos do Merlim profeta na Idade Média, já que ao ser denominado como tal ele não estaria diretamente ligado à bruxaria, mas sim ao demônio e ao maligno.

Boron foi o primeiro a apresentar a história do mago em prosa, assim como a história de Artur, seus cavaleiros e do santo Graal. 0 então mago surge com a tarefa de aconselhar os reis e, como um excêntrico profeta auxiliado por Deus, faz revelações sobre o Graal 
e a Távola Redonda, sempre com o intuito de salvar a Grã-Bretanha por meio de um rei cristão. A história em prosa fez com que a obra pudesse ser lida mais facilmente, ultrapassando as barreiras das fronteiras britânicas, para se tornar um trunfo cristão na cultura francesa. Com isso, suas características sobrenaturais uniram o mundo cívico com o mundo histórico.

Outro ponto importante na obra escrita por Boron é o uso de Blaise, ou seja, o uso de um narrador que ao mesmo tempo passa a ser um observador, uma testemunha e uma prova viva de todas as proezas de Merlim, esse narrador aproximou o mago do leitor, deixando o texto mais crível e o sobrenatural mais mágico. Essa aproximação com o leitor, em grande medida, possibilita a manutenção e a propagação da lenda, mantendo esse personagem vivo no imaginário do leitor.

Após o século $X X$, este personagem medieval torna-se ainda mais conhecido pelas séries televisivas e pelos filmes, mas sempre retomado como imagem de um mentor ou de um mestre do rei Artur, além de ser também inspiração para outros magos da cultura popular, como aqueles criados por J. R. R. Tolkien e por J. K. Rowling. Mesmo muito conhecido no meio da cultura popular, o Merlim medieval ainda é nebuloso para os leitores. Pensando nisso, busca-se apresentar o processo de cristianização ocorrido na obra de Boron.

Para tanto, discutiremos a construção da imagem do personagem na obra escrita no século XIII, com vista nas relações de intertextualidade com a Bíblia encontradas no texto, para em seguida justificarmos, de certa forma, o objetivo do autor em 
reescrever a história de um personagem já muito conhecido na Idade Média, modificando-o para agradar tanto os patronos quanto os leitores.

\section{RELIGIÃO: A CONSTRUÇÃO DA IMAGEM DE MERLIM}

O livro Merlim, escrito por Robert de Boron, no século XIII, é uma obra publicada em uma época na qual a literatura era permeada de mitologias. Isso se dava por diversas razões, uma delas, já mencionada anteriormente, era o poder exercido pela igreja católica, poder político e econômico que influenciava na criação artística.

Boron (1993) declara que o seu personagem misterioso atuou na Inglaterra em um momento em que o cristianismo havia acabado de se instalar, por isso a região ainda não tinha tido nenhum rei cristão. No entanto, mesmo Merlim sendo de uma época não cristã, sua lenda advém de outras crenças. Segundo Adam Ardrey, algumas das fábulas sobre o mago "foram elaboradas para se adequar às exigências dos regimes políticos e religiosos prevalecentes e adaptadas para se ajustar ao público" (ARDREY, 2010, p.15).

A obra de Robert de Boron se inicia com um concelho realizado pelos demônios, que descontentes com as obras de Cristo, planejam criar um representante para corromper a humanidade. Ao nascer, Merlim frustra os planos demoníacos quando sua mãe, por ser temente a Deus, o batiza. Dessa forma, a criança nasceu com o dom de conhecer o passado, recebido por herança de seu progenitor, e com o dom de prever o futuro, presente de Deus ao ser batizado.

Sua história continua com demonstrações dos seus incríveis poderes proféticos, começando ao salvar sua mãe do julgamento, 
para, então, aos sete anos aconselhar o rei usurpador Vortigerne sobre a fundação de sua torre. Seu aconselhamento aos reis continuou ao ajudar o rei Pendragão e seu irmão Uter em suas batalhas. No momento seguinte da obra, Merlim interfere diretamente na concepção e na criação do que será o rei Artur, assim como no seu encontro com a espada repousada na pedra, essa que o legitima como o rei supremo da Grã-Bretanha.

As histórias narradas na Idade Média faziam parte do universo mágico e eram usadas para compensar as dificuldades da vida real. Devido a outra forte característica da época, a religião, os elementos religiosos encontrados na obra de Boron nos permitem traçar os dogmas da época. Nesse sentido, Pereira (2001-2002) explica a presença marcante das expressões bíblicas na literatura. Para ele,

Utilizar expressões bíblicas para narrar outros acontecimentos era mais do que um ornamento literário, consistia em transladar para ele o sentido profundo que tinha na Sagrada Escritura, não só em termos profundos que tinham na Sagrada Escritura, não só em termos comparativos, mas também para os inscrever no mesmo significado das narrações bíblicas, ou seja, atribuía um caráter sagrado ao texto e às memórias que ele perpetua, integrava a história profana na história da salvação. (p.320)

A marca da religião católica pode parecer normal em uma primeira leitura do texto, principalmente ao se considerar a época em que ela foi escrita, porém, se pensarmos nos personagens e nas lendas envolvidas, a presença católica se torna um ponto de estranhamento, pois tanto Merlim quanto a lenda de Artur e o santo Graal são mais antigos e advindos de outras religiões e culturas, 
haja vista que o personagem principal da obra de Boron (1993) foi um personagem druida muito importante para a cultura celta.

De acordo com Ardrey (2010), os costumes druidas eram intoleráveis para a Igreja, por essa razão, os registros escritos, que se tornaram mais comuns com o passar dos séculos, eram usados para refletir os preceitos religiosos, para isso, a Igreja ditava o que e como deveriam ser registradas as histórias. Dessa maneira, o estranhamento provocado por uma leitura mais minuciosa da obra, quando examinamos o tema escolhido pelo autor, assim como os personagens, pode ser justificado, já que, ainda segundo Ardrey (2010), todos os registros de outras culturas eram cuidadosamente ordenados pela Igreja católica para que seus preceitos não fossem questionados.

Assim disseram e decidiram que gerariam um homem que enganaria os outros. São loucos demais, porque imaginam que Nosso Senhor, que tudo sabe, ignore suas obras. 0 diabo então decidiu fazer um homem que tivesse a sua memória e a sua inteligência para enganar Jesus Cristo. Deste modo podeis saber o quanto é louco o diabo, e muito devemos temer, porque tão louca cousa nos engana. (BORON, 1993, p.23-24)

Borges (2011), em seu artigo O Maravilhoso Cristão em A Canção de Rolando, também fala sobre a literatura dessa época. Para a autora, a cultura, assim como as obras religiosas, eram de poder da Igreja, "As hagiografias, as crônicas, as canções de gesta, assim como as demais criações passavam pela concepção das Sagradas Escrituras" (p.2).

Essa influência se dava também pelos textos serem escritos, isto é, pelos motivos que justificavam tal criação literária, como melhorar 
os costumes, servindo como modelo de vida e desenvolvendo maneiras e morais para que os leitores fizessem o bem e evitassem o mal, o que Bogdanow (1994) salienta em O Graal, Artur e Merlim segundo Robert de Boron:

Para os escritores medievais, como já para os padres da Igreja, a história era [...] 'uma ciência moral, que se estudava para melhorar os costumes'. Como São Gregório observou em Moralia, [...] 'a vida dos predecessores serve de modelo aos sucessores', ou como William de Malmesbury observa em seu Gesta Regum: '[...] a história em particular, que, através do conhecimento agradável dos feitos, desenvolve maneiras e moral e, através de exemplos, incita o leitor a fazer o bem e evitar o mal'. (p.180)

A produção literária era, antes de tudo, textos produzidos para que fossem usados para ensinar, mostrar ao leitor o bom caminho, para, de certa forma, catequizar aqueles que tinham acesso às produções literárias da época. Não poderia ser diferente com a obra de Boron (1993), visto que o mago Merlim, em toda a literatura do ciclo Arturiano, tinha como sua principal função auxiliar e aconselhar o povo, os reis, os cavaleiros e até mesmo a Igreja. Apesar de não ser um cavaleiro, ele é responsável por determinar guerras, estabelecer a paz e a justiça, regulamentar e ordenar os cavaleiros.

A história contada por Robert de Boron no século XIII começa no inferno com uma reunião dos diabos irritados, querendo recuperar o poder, para tanto, eles chegam a uma decisão de pôr sobre a terra alguém capaz de desviar os homens do bom caminho, escolhem uma virgem para gerar essa criança, mas eles não esperavam que ela fosse temente a Deus e que batizaria a criança. Por parte do seu 
pai, um demônio, Merlim recebeu o dom de conhecer o passado, mas, por ter uma mãe temente à Deus, ele recebeu o poder de prever o que ainda vai acontecer.

Contudo, além das menções claras da história católica apresentada na Bíblia, como Deus e demônios, perguntamo-nos: o que mais a obra de Boron (1993) apresenta sobre as práticas dessa religião? Por que isso acontece? Essas questões conduzem o presente artigo, a fim de evidenciar, por meio da convergência e da divergência entre o texto fonte, no caso a Bíblia, e o texto do Boron (1993), o processo de cristianização do personagem.

Para tanto, traçaremos uma fundamentação teórica sobre intertextualidade, para justificar a aproximação dos textos como uma maneira de legitimar o personagem a partir de uma breve análise do texto Merlim, de Robert de Boron, publicado em português, em 1993, o qual foi traduzido diretamente do francês antigo.

\section{INTERTEXTUALIDADE NOS TEXTOS LITERÁRIOS}

A intertextualidade é estudada a partir de duas perspectivas, a Linguística Textual e a Teoria Literária. Em relação ao texto literário, que tem uma maior importância para este artigo, a intertextualidade sempre se fez presente e foi muito debatida por diversos teóricos, isto, pois o escritor sempre recorre a outras obras para escrever suas "criações". De acordo com Leyla Perrone-Moisés (1978), estudiosa da teoria literária,

Em todos os tempos, o texto literário surgiu relacionado com outros textos anteriores ou contemporâneos, a literatura sempre nasceu da e na literatura. Basta lembrar as relações temáticas e formais de inúmeras grandes obras 
do passado com a Bíblia, com os textos grecolatinos, com as obras literárias imediatamente anteriores, que lhes serviam de modelo estrutural e de fonte de 'citações', personagens e situações [...]. (1978, p.59)

Ainda sobre a intertextualidade, Berveglieri $(2016$, p.34) afirma que: "só é possível apreender o sentido e a estrutura de uma obra literária se a relacionar com seus arquetípicos, que são, por sua vez, abstraídos de longas séries de textos". Um outro teórico muito importante para os estudos da intertextualidade na literatura é Genette (2010), autor que define, em seu livro Palimpsestos (2010), cinco tipos de transtextualidades.

Essas categorias servem para referenciar a relação que um texto mantém com outro, sendo elas a intertextualidade, quando há uma presença real de um texto em outro, algo como uma citação; a paratextualidade, que é concernente aos paratextos que circulam entre os textos, uma menção de um texto em outro; a terceira categoria apresentada pelo autor, a metatextualidade, ocorre quando há uma crítica ou um comentário; a arquitextualidade diz respeito ao gênero textual em que esses textos se relacionam; o último tipo é a hipertextualidade, a qual, para o autor, é toda a relação que une um texto ao outro, "ou texto derivado de outro texto preexistente. Esta derivação pode ser de ordem descritiva e intelectual, em que um metatexto [...] fala de um texto" (GENETTE, 2010, p.18).

Em relação à hipertextualidade, Genette (2010) declara ser possível haver dois tipos de procedimentos, ambos relacionados à imitação: a imitação da forma e a imitação do tema, a imitação se caracteriza "[...] pela brevidade, pela afirmação peremptória e pela 
metaforicidade; depois, que exprima dessa maneira (nesse estilo) uma outra opinião, corrente ou não [...]" (2010, p.20).

O ato de imitar, para Genette (2010), acontece de diversas maneiras, assim como acontece com a paródia, que pode se manifestar de três maneiras: pela aplicação de um texto a um outro tema, pela transposição de um texto para outro estilo e pela aplicação de um estilo a um outro tema. $\mathrm{O}$ autor configura esses tipos de paródia a partir do desvio que o parodista realiza do texto primário, sendo que,

No primeiro caso, o "parodista" desvia um texto do seu propósito, modificando-o apenas o quanto for necessário; no segundo, ele o transpõe integralmente para um outro estilo, deixando seu propósito tão intacto quanto esta transformação estilística permita; no terceiro, ele toma emprestado o estilo do texto para compor neste estilo um outro texto, com um outro propósito, preferencialmente antitético (2010, p.29).

Ainda sobre a paródia, Genette (2010, p.39) (re)batiza o termo como um "desvio de texto pela transformação". Dessa forma, as imitações e as transformações são norteadas por esse desvio, quando em ambos os textos existem modificações em suas estruturas.

Um outro teórico que trata a paródia a partir do desvio do texto é Sant'Anna (2003). Para ele, na paródia os dois textos "devem ser necessariamente discordantes, deslocados", como ocorre na estilização, a qual se aproxima da paródia, haja vista que "uma e outra vivem de uma vida dupla: além da obra há um segundo plano estilizado ou parodiado" (2003, p.13).

Essa aproximação ou esse afastamento entre os textos só se realiza a partir da leitura, ou seja, o receptor é responsável por 
identificar a proximidade entre os textos, isto pois a estilização, a paráfrase e a paródia "[...] são recursos percebidos por um leitor mais informado. É preciso um repertório ou memória cultural e literária para decodificar os textos superpostos" (SANT'ANNA, 2003, p.26).

O autor também debate sobre os efeitos da intertextualidade nos textos linguísticos e literários. Para ele, a intertextualidade se organiza em torno do eixo parafrásico e do eixo paródistico, tendo visto que a paráfrase e a paródia "[...] se tocam num efeito de intertextualidade, que tem a estilização como ponto de contato. Falar de paródia é falar de intertextualidade das diferenças. Falar de paráfrase é falar de intertextualidade das semelhanças" (SANT'ANNA, 2003, p.28, grifos do autor).

Ainda nesse viés, segundo Röhrig (2012, p. 14-15),

a paráfrase não subverte o texto original, mantendo o sentido exatamente igual ao parafraseado, podendo-se identificar a fonte sem quaisquer dificuldades, na estilização ocorre um sutil deslocamento de sentido, mas que não corrompe o sentido global do discurso original ainda na direção do reforço, como na paráfrase. No entanto, a paródia deturpa os sentidos, corrompe o textobase, promovendo um atrito significativo com as teses do discurso parodiado.

A autora conclui que "a paráfrase é um desvio mínimo, a estilização [...] constitui-se em um desvio tolerável e a paródia concretizaria um desvio total do sentido original de determinado texto" (RÖHRIG, 2012, p.15). Quanto ao distanciamento em relação ao texto fonte, Beverglieri (2016) salienta que 
quanto maior o distanciamento da voz do autor do texto-fonte maior será a desqualificação desse texto, tendo como exemplo a 'citação negativa', a paródia; quanto maior for a aproximação, maior será a autorização da voz do autor do texto-fonte, tendo-se a paráfrase, a 'citação positiva', por exemplo. Essa relação, então, ocorre desde uma maior aproximação até um maior distanciamento, promovendo, nesse processo, fenômenos como a citação positiva, a paráfrase, o pastiche, ironia, paródia até uma citação negativa (p.49).

Para realizarmos uma análise do texto de Boron (1993), tem-se também o modelo criado por Sant'Anna (2003), porém ele acredita não ser possível empregá-lo em todos os objetos. Entretanto, considerando as complexidades que envolvem o tema, procuramos evidenciar a convergência e a divergência entre o texto fonte e o novo texto produzido.

Consideramos, para isso, que o sentimento de reconhecimento da obra é produzido pelas referências trazidas pelo autor, as quais podem ser de temas, eventos, personagens e até mesmo de cultura. Graças a esses pontos convergentes e divergentes, para o leitor que entra em contato com uma obra com intertextualidades, como Merlim (1993), é inevitável que ocorra um processo de reconhecimento, afinal é um processo dialógico no qual se compara as duas obras, a conhecida e a que se está lendo (HUTCHEON, 2011).

\section{PONTOS CONVERGENTES E DIVERGENTES ENTRE MERLIM E A BÍBLIA}

O livro estudado, Merlim (1993), faz parte das obras em prosa do autor que reconta a história do Graal. Como outros autores da época, Boron era responsável por transmitir pelas suas histórias a 
moral da época, o pensamento dominante e a cultura presente. Bogdanow (1994), em seu artigo, explica que a inspiração de Boron é dada a partir de duas vertentes. De acordo com a autora, uma parte da história é baseada em escritos anteriores, enquanto a segunda é dada pela Bíblia, pois Robert de Boron reescreve as antigas histórias para adaptar-se ao ensino religioso e aos temas cristãos (BOGDANOW, 1994).

Como mencionado anteriormente, Merlim é um personagem com origens mitológicas e ligado à magia, ambas características não seriam bem aceitas pelos leitores de Boron ou não seriam eficazes para os fins que o autor procurava alcançar com sua obra. Logo, iniciar a história da concepção do mago pagão relacionando-o ao início das histórias bíblicas aproximar-lhe-ia dos leitores religiosos.

No primeiro capítulo do livro, Robert de Boron justifica a criação de Merlim. Os demônios estão em cólera por terem perdido Adão e Eva do inferno, um deles diz: "Lembrai-vos do que diziam os profetas que anunciavam que o Filho de Deus viria à terra para apagar o pecado de Adão e Eva e de seus descendentes" (BORON, 1993, p.21). Tendo isso em mente, em / Coríntios temos: "Pois, assim como todos morrem em Adão, em Cristo todos receberão a vida" (BÍBLIA, I Coríntios 15:21).

As duas passagens citadas fazem referência a mesma história, possuem um ponto de contato, a salvação dos homens por Jesus Cristo, ou seja, segundo a teoria de Röhrig (2012), ocorre um desvio mínimo já que a mesma história está sendo contada, a história da salvação, porém em obras contrárias, uma bíblica e outra literária. 
Em um segundo momento, o ponto de contato e o desvio são um pouco maiores. Os demônios decidem criar um homem para servir-lhes, para isso, fecundando uma mulher para que a criança fosse gerada. Após o ato da fecundação, a donzela acorda com medo do que lhe aconteceu e rapidamente procura seu ermitão para confessar-Ihe: "E do modo que me deitei inteiramente vestida, adormeci. Ao acordar, tomei conta de que estava desonrada e deflorada" (BORON, 1993, p.34). Uma virgem foi engravidada por um espírito enquanto dormia, o que retoma e se aproxima da história de uma outra virgem para relacionar Merlim a uma outra criança responsável por grandes feitos. Para melhor visualização, no livro de Isaías, assim como no evangelho de Lucas, temos:

Eis que a jovem [a tradução grega traz 'a virgem'] concebeu e dará à luz um filho e pôr-lhe-à o nome de Emanuel (BÍBLIA, Isaías, 7:14).

O Espírito Santo cairá sobre ti e o poder do Altíssimo vai te cobrir com a sua sombra, por isso o Santo que nascer será chamado Filho de Deus. (BÍBLIA, Lucas, 1:25)

Nesse caso, o desvio é maior, pois, na história bíblica Maria foi fecundada, só que em nenhum momento afirma-se que ela deixou de ser virgem, que se tornou impura, diferentemente da mãe de Merlim, que foi deflorada e, mesmo pedindo perdão, tornou-se impura.

Esse grande desvio faz com que tenhamos uma paródia da criação de Cristo. Podemos supor diversas razões para esse distanciamento, um dos mais claros seria para mostrar em quais lados localizam-se as duas crianças, demarcando os opostos em que estão na história. Confirmando o que Sant'Anna explica sobre a 
caracterização da paródia, isto é, "a dessacralização, o desrespeito à obra do outro" (2003, p.46).

Boron procurou cristianizar o protagonista de sua obra da forma mais eficaz possível, comparando-o com o herói católico, deixando-o próximo da figura cristã para que houvesse uma identificação entre sua obra e o religioso, sem deixar de estar no mesmo nível de sagrado. Além disso, o autor não usa somente trechos bíblicos para produzir o seu texto, por exemplo, quando a mãe de Merlim descobre sua gravidez e conversa com o ermitão, encontramos também menção a oração do Credo Apostólico,

- Crês no Pai, no Filho e no Espírito Santo? Crês que essas três pessoas fazem um só Deus? Crês que Nosso Senhor veio à terra para salvar todos os pecadores que acreditarem no poder do batismo e dos outros sacramentos da Santa Madre Igreja e obedecem aos ministros que ele deixou na terra para ensinar e acreditar no seu nome? (BORON, 1993, p.30-31)

O desvio referente ao Credo é médio, até porque tanto na oração quanto no trecho citado temos questões que conduzem a fé católica, que salientam a importância de tal crença e principalmente dessa oração que é utilizada nas consagrações, batismo e crisma. Seguindo esse sentido, Casanova e Stam (1998) expõem a falta de conhecimento quanto ao surgimento da oração do Credo, sabe-se que é anterior ao século II e que foi criada para que a fé dos novos cristãos fosse declarada, pois a expansão missionária e a heresia fizeram com que a Igreja estivesse em constante contato com diversas culturas e filosofias pagãs.

Nesse momento, notamos novamente a intenção de Boron em aproximar sua obra do ensino religiosos e da redenção. Com 
o uso de tal declaração, a criança torna-se pura, assim como sua mãe, orientando seus leitores de que a redenção pode acontecer a partir de uma oração e declaração de sua fé cristã. O desvio é tolerável, sendo "[...] o máximo de inovação que um texto poderia admitir sem que se lhe subverta, perverta ou inverta o sentido" (SANT'ANNA, 2003, p.39). Com isso, Boron utiliza a religião em seu texto para difundir os ideais católicos, mostrar o caminho da salvação e abrandar as atitudes julgadas como pecadoras e erradas pela Igreja Católica.

Assim como Jesus, Merlim foi caçado para ser morto e, também como o Salvador Cristão, entregou-se sem lutar, "- Senhores, eu sou quem buscais, aquele a quem jurastes matar [...]" (BORON, 1993, p.67). No evangelho de João, é exortado que, estando no jardim ao ser encontrado, Jesus adiantou-se e disse: "Se, então, é a mim que procurais, deixai que estes se retirem [...]" (BÍBLIA, João, 18:8). O desvio nesse momento se torna pequeno, haja vista que "a paráfrase reafirma os ingredientes do texto primeiro conformando seu sentido" (SANT'ANNA, 2003, p.41).

Em um outro momento, Boron também utilizou o dom de Jesus de se manifestar "de outra forma" (BÍBLIA, Marcos 16:12). Merlim em vários momentos se aproveita do poder de transformar a sua imagem, como vemos no momento em que fala com Uter, "Merlim - disse Pendragão maravilhado-, sob que aparência falastes com meu irmão? Estou admirado que ele tenha acreditado no que dissestes. - Eu tinha assumido a aparência de um velho de cabelos brancos" (BORON, 1993, p.95).

Além disso, em vários momentos a Bíblia evidencia os poderes de Jesus. Quando há a necessidade de testar a fé de algum discípulo 
ou de seus seguidores, Cristo toma outras formas, assim como Merlim faz para verificar se os reis realmente acreditavam nele. Dessa forma, com um desvio moderado, "a estilização reforma esmaecendo, apagando a forma, mas sem modificação essencial da estrutura" (SANT'ANNA, 2003, p.41).

Assim como nesses trechos escolhidos e destacados, podemos encontrar em vários outros momentos a presença de textos religiosos, da Bíblia e dos costumes católicos nos escritos de Robert de Boron. Para Bogdanow (1994, p.182), "Robert de Boron, que não estava menos imerso na teologia mística de São Bernardo do que Chrétien [...] insiste em que aqueles que lerem o 'livro' atentamente 'serão por isso os melhores e sem pecado". Dessa forma, o herói torna-se simpático aos olhos do leitor que reconhece no livro as histórias bíblicas.

De forma eficaz, por meio de uma produção intertextual de narrativa ficcional, Boron (1993) sugere um determinado comportamento para uma sociedade, comportamento baseado em sua visão do mundo, além de modificar um personagem mitológico restrito à cultura celta, para que esse se torne um personagem próximo às culturas da religião Católica.

\section{CONCLUSÃO}

O sentimento de reconhecimento da obra é produzido por intermédio das referências utilizadas por Boron (1993), tanto referências relacionadas aos temas, como vimos em relação à oração do Credo, de eventos, quando a virgem é fecundada, quanto de personagens, como o momento em que Merlim se entrega aos seus captores ou ainda quando se transfigura em outra pessoa. Todos 
essas aproximações e esses desvios estão presentes na obra e se valem de um objetivo, como visto anteriormente, o de catequizar, fazendo com que seus leitores se mantivessem distantes do pecado e próximos do cristianismo.

Por meio das teorias apresentadas, principalmente a de Genette (2010) e de Sant'Anna (2003), percebemos e discutimos a intertextualidade presente na produção desta obra literária, explanando as razões para tal uso. Notamos, com isso, que Boron parte de uma lenda celta, de um personagem conhecido pela população da época, e acrescenta características cristãs à história.

Aqueles que deviam se converter e seguir a religião dominante acabavam por identificar os vestígios de seus antigos costumes. Essa identificação podendo facilitar a conversão e a catequização desse povo, uma das ações exigidas ao autor que era clérigo. Da mesma forma, um leitor que conhece a história cristã de Jesus, ao ler o livro Merlim, constata seus conhecimentos, enquanto que aqueles que creem na religião também reconhecem a sua crença.

Essa identificação provocada pela escrita do autor, que modificou o personagem mítico para torná-lo quase humano e desmistificar o druidismo, ao mesmo tempo que impõe uma nova religião, fez com que Merlim fosse mantido nas histórias produzidas após a Idade Média, mantendo-se nas histórias arturianas escritas após sua época.

Concluímos, dessa maneira, que a intertextualidade, recurso empregado no texto literário, pode claramente servir para diversas razões, sendo, neste caso, utilizada na produção temática, composicional e de estilo por razões políticas, afinal o autor se vale 
do artifício para incutir um novo modo de pensar em um povo. Nos dias de hoje, notamos que ele conta com o recurso intertextual para aproximar dois credos e duas culturas, criando, assim, um novo personagem e uma nova história que está presente no universo mítico, fantástico e maravilhoso até os tempos modernos.

\section{REFERÊNCIA}

A BíBLIA DE JERUSALÉM (1985). Português. São Paulo: Paulus Editora, Brasil. ARDREY, Adam (2010). Em busca de Merlim. Rafael Aragon Guerra (Trad.). Rio de Janeiro: Record.

BERVEGLIERI, Sônia (2016). Do filme ao livro: as relações intertextuais entre o filme O Diário de Bridget Jones e o livro Orgulho e Preconceito. Maringá - PR. Dissertação (Mestrado em Letras) - Universidade Estadual de Maringá, 2016. In http://www.ple.uem.br/ defesas/pdf/sberveglieri.pdf Acesso em 02.Jun.2018.

BOGDANOW, Fanni (1994). O graal, Arthur e Merlim segundo Robert de Boron. In Revista USP. São Paulo, 21, 179-197.

BORGES, Maria do Carmo Faustino (2011). O maravilhoso Cristão em A Canção de Rolando. X Jornada de Estudos Antigos e Medievais. Anais. Maringá, p.1-13. BORON, Robert de (1993). Merlim.. Heitor Megale (Trad.). Rio de Janeiro: Imago Ed.

CASANOVA, Humberto; STAM, Jeff. El credo Apostólico. Exerton B. (Trad.). Tokashiki Grad Rapids. In http://www.monergismo.com/textos/credos/ introducao_credo_apostolico.htm. Acesso em 02.Jun.2018.

GENETTE, Gérard (2010). Palimpsestos: a literatura de segunda mão. Belo Horizonte: Edições Viva Voz.

HUTCHEON, Linda (2011). Uma teoria da adaptação. André Cechinel (Trad.). Florianópolis: Editora da UFSC.

LAWRENCE-MATHERS, Anne (2012). True History of Merlin the Magician. New Haven and London: Yale University Press.

PEREIRA, Armando de Sousa (2001-2002). Motivos bíblicos na historiografia de Santa Cruz de Coimbra dos finais do Século XII. Lusitana Sacra, 2a série, 13-14, 
p.315-336. In https://repositorio.ucp.pt/bitstream/10400.14/4415/1/LS_S2_1314_ArmandoSPereira .pdf Acesso em 02.Jun.2018.

PERRONE-MOISÉS, Leyla (1978). Crítica e Intertextualidade. In: Texto, Crítica, Escritura. São Paulo: Ática.

RÖHRIG, Adriana (2012). As intertextualidades em Videiras de Cristal: enfocando as paródias. Revista Trama, 8(15), 11-25.

SANT'ANNA, Affonso Romano de (2003). Paródia, Paráfrase \& Cia. São Paulo: Editora Ática. 


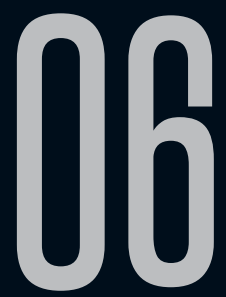

\section{"TIRO NÃO O MATA, FOGO NÃO O QUEIMA, ÁGUA NÃO O AFOGA": AS REFIGURAÇÕES DE MACOBEBA NO MODERNISMO BRASILEIRO}

Nabil Araújo (UERJ)

Thayane Verçosa (UERJ)

Recebido em 08 dez 2019. Nabil Araújo é Doutor em Estudos Literários pela Aprovado em 26 fev 2019. Universidade Federal de Minas Gerais (UFMG). Professor de Teoria da Literatura na graduação e na pós-graduação em Letras da Universidade do Estado do Rio de Janeiro (UERJ). Vice-Diretor e Coordenador de Licenciaturas do Instituto de Letras da UERJ. Líder do grupo de pesquisa interinstitucional "Retorno à Poética: imagologia, referenciação, genericidade". É autor de O evento comparatista: da morte da literatura comparada ao nascimento da crítica (no prelo). Organizou A crítica literária e a função da teoria: reflexão em quatro tempos (2016) e Imagens em discurso: efeitos de real, efeitos de verdade (no prelo); coorganizou Variações sobre o romance (2016), Variações sobre o romance II (2018) e Imagens de Fausto: história, mito, literatura (2017). Pela sua tese, $O$ evento comparatista: na história da crítica / no ensino de literatura, recebeu o Prêmio UFMG de Teses, em 2014, e o Prêmio ANPOLL de Teses, em 2016. Seu projeto "Ensino de literatura e desenvolvimento da competência crítica: uma 'terceira via' didático-pedagógica" foi premiado pela Fundação Carlos Chagas como a melhor experiência educativa inovadora realizada por docente de Licenciatura em 2014. Em 2015, foi contemplado 
com o Prêmio Docência Dedicada ao Ensino Anísio Teixeira, conferido pela Sub-Reitoria de Graduação da UERJ. Pesquisa e produção na área de Letras: Teoria da Literatura, História da Crítica, Ensino de Literatura.

Thayane Verçosa é Mestranda em Teoria da Literatura e Literatura Comparada pela Universidade do Estado do Rio de Janeiro e bolsista da CAPES. Faz parte do grupo de pesquisa "Retorno à Poética: imagologia, referenciação, genericidade", coordenado pelo professor Nabil Araújo.

Resumo: Partindo das colunas assinadas por José Mathias no periódico A província, de abril a setembro de 1929, nas quais as peripécias e as atrocidades de Macobeba são narradas, pretendemos analisar, comparar e contrastar o modo como o monstro reaparece em diferentes contextos e obras do Modernismo brasileiro. Para tanto, o nosso corpus é composto também, em ordem cronológica, por "Macobeba" (1929), de Mário de Andrade; pelos textos "Macobeba pré-histórico" (1930) e "Macobeba antigo" (1930), de Graciliano Ramos; e pelo Manuscrito Holandês ou a peleja do caboclo Mitavaí com o Monstro Macobeba (1960), livro de Manuel Cavalcanti Proença. Desse modo, a partir do conceito de refiguração (REIS, 2018), buscaremos analisar como ocorrem as reelaborações do monstro, atentando para os procedimentos retóricoestilísticos usados nas diferentes composições, e para o modo como elas dialogam, destacando eventuais aproximações e afastamentos.

Palavras-chave: Modernismo brasileiro; Refiguração; Sobrevida; Imagologia; Macobeba.

Abstract: Beginning with the columns published from April to September of 1929 by José Mathias in the newspaper A província, in which Macobeba's adventures and atrocities are narrated, we intend to 
analyze, to compare and to contrast how the monster reappers in different Brazilian Modernism's works. In order to achieve this goal, besides the mentioned columns, we will also study: "Macobeba" (1929), a text from Mário de Andrade, "Macobeba pré-histórico" (1930) and "Macobeba antigo" (1930), written by Graciliano Ramos; and Manuscrito Holandês ou a peleja do caboclo Mitavaí com o Monstro Macobeba (1960), a book written by Manuel Cavalcanti Proença. Therefore, with the idea of refiguration (REIS, 2018), we intend to analyze how Macobeba reappears in different works, highlighting the rhetorical and stylistic procedures used in the works. Besides, we also intend to show that there is a dialogue among them and to point how it works.

Keywords: Brazilian modernism; Refiguration; Afterlife; Imagologia; Macobeba.

\section{INTRODUÇÃO}

O presente artigo tem como objetivo analisar e comparar as refigurações do monstro Macobeba ${ }^{1}$ no Modernismo brasileiro. Para isso, partimos de sua primeira aparição, em 7 de abril de 1929, no periódico A província, que dá início a uma série de crônicas quase todas assinadas por José Mathias (Júlio Bello) - que narram, comentam e descrevem as peripécias do monstro, "[g]rande, muito grande, do tamanho de uma sucupira de meio século, com um extenso rabo metade de leão e metade de cavalo, quatro imensos olhos vermelhos como quatro grandes brasas vivas a flor da cara, aduncas unhas de 'lobisomem'"' (MATHIAS, 1929).

1 Em todos os textos consultados nos periódicos, i.e., os de José Mathias, José Lins do Rego, Estevão Pinto e Mário de Andrade, o monstro é chamado de Macobêba. Na coletânea de inéditos de Graciliano Ramos, Garranchos (2012), organizada por Thiago Mio Salla, e no livro A peleja do caboclo Mitavaí com o monstro Macobeba, o acento circunflexo caiu, sendo esta a grafia que optamos por adotar aqui. 
Depois desse primeiro momento, dando sequência à análise das figurações do personagem em ordem cronológica, o segundo texto estudado é "Macobeba", de Mário de Andrade, publicado originalmente em 1929, na sua coluna "Táxi", do periódico Diário Nacional, e posteriormente inserido na coletânea Os filhos de Candinha (1943). Diferentemente de José Mathias, que, além de ter criado o monstro, escreveu diversas crônicas sobre ele, o autor de Macunaíma aborda a personagem em apenas um texto.

No terceiro momento analisado, Lúcio Guedes, pseudônimo eventualmente usado por Graciliano Ramos em algumas publicações no Jornal de Alagoas, traz o monstro para o centro de dois textos: "Macobeba pré-histórico" e "Macobeba antigo", ambos publicados em 1930. Eles saem também, muitos anos depois, na coletânea de inéditos Garranchos (2011).

O quarto momento analisado pertence à década de 1960, quando Manuel Cavalcanti Proença escreve Manuscrito holandês ou a peleja do caboclo Mitavaí com o monstro Macobeba. A besta, presente já desde o título da obra, ocupa uma posição de destaque na trama, figurando como um vilão a ser combatido, derrotado e expulso da cidade pelas mãos do herói indianista Mitavaí, em uma trama recheada de lendas, mitos, figuras maravilhosas e referências claras a outras notórias obras, como Macunaíma e Odisseia.

É relevante destacar, à guisa de curiosidade, que além de todas essas aparições do monstro em diferentes obras literárias, como brevemente mostrado acima, Macobeba também povoou o imaginário popular. Luzia Aparecida Oliva dos Santos e Sérgio Motta 
no artigo "Cavalcanti Proença: quadros de Mitopoética" (2008), em uma nota de rodapé, afirmam que:

Diz a tradição que, em Olinda, nos anos 40, o medo do Macobeba tomava conta da população. Grotescamente era descrito da seguinte forma: "capa preta, enorme cartola enfiada na cabeça até as orelhas. Enormes, reluzentes e afiadas presas se cruzavam fora da boca. Barba rala, orelhas de abano, fedendo a enxofre. Unhas enroscadas e mãos cabeludas. De poucas palavras, voz grossa e rouca". Aparecia em noites escuras, atacando mulheres, preferencialmente, com exceção das gordas e feias. (p.3)

Ainda sobre essa vertente mais popular, Thiago Mio Salla, em Graciliano Ramos e cultura política: mediação editorial e construção do sentido, assegura que:

Tal figura mitológica fora imaginada por José Mathias, no jornal $A$ Província do Recife, em 1929, e, logo depois, cantada em folhetos por poetas populares. Uma das cantigas dizia: É um tal de Macobeba / Bicho feio e valentão / Tem quatro olhos enormes / Que parece ser o cão, / Tem as unhas tão compridas / Que nem mesmo um gavião [...]. // Faz o diabo Macobeba; / Devasta tudo onde passa, / Derruba porta de engenho / Bebe toda cachaça, / "E sai como um pé de vento / Inda soltando fumaça”. (SALLA, 2016, p.95)

As expressões populares de Macobeba dão mostra da presença do monstro também no imaginário popular, e de que o personagem não sobreviveu apenas por obra de autores renomados. Assim, todas essas reaparições da besta, aqui com ênfase nas do Modernismo 
brasileiro, são exemplos de refigurações dessa personagem, observando-se que:

O conceito de refiguração decorre da noção de figuração e reporta-se ao processo de reelaboração narrativa de uma figura ficcional (normalmente uma personagem), no mesmo ou em diferentes suportes e linguagens. Pressupõe-se, deste modo, que as figuras ficcionais não são entidades restringidas $\mathrm{e}$ estaticamente fixadas na figuração a que uma certa narrativa se submeteu. (REIS, 2018, p.421)

Como a ideia de refiguração parte do conceito de figuração, isto é, "um processo ou um conjunto de processos discursivos e metaficcionais que individualizam figuras antropomórficas, localizadas em universos diegéticos específicos, com cujos integrantes aquelas figuras interagem, enquanto personagens" (REIS, 2018, p.165 - grifo nosso), a fim de analisar as diferentes reaparições de Macobeba, a realização de um estudo imagológico se faz necessária, uma vez que a imagem em um texto sempre é construída a partir de procedimentos discursivos: "[a] imagem [...] "em um texto é primeiramente um conjunto de palavras, um léxico para dizer o Outro" (PAGEAUX, 2011, p.112), de modo que "[c]onvém, em um texto, identificar o campo lexical, as possíveis isotopias, os processos de comparação que são espécies de equivalentes ou de aproximações para dizer o Outro, ser atento à adjetivação, expressão elementar do julgamento de valor e de hierarquização" (PAGEAUX, 2011, p.122).

Nesse sentido, é relevante também lembrar que:

Toda imagem procede de uma tomada de consciência, por mínima que seja, de um Eu em 
relação a um Outro, de um aqui em relação a um alhures. Portanto, a imagem é a expressão, literária ou não, de um distanciamento significativo entre duas ordens de realidade cultural. [...] A imagem é uma espécie de língua, de língua segunda para dizer o Outro e, consequentemente, para dizer também um pouco de si, de sua cultura. (PAGEAUX, 2011, p.110-111)

Ao atentar para os elementos de análise apontados por Pageaux, que revelam a(s) imagem(ns) construída(s) de Macobeba, vale a pena observar ainda que "os elementos estruturantes da narrativa [...] [são considerados] como os traços dos processos interacionais e pragmáticos em que o escritor opera escolhas, em função da situação, do gênero, da imagem dos leitores, etc." (RABATEL, 2016, p.15-16).

Tal análise será feita com o intuito de perceber e contrastar como a imagem de Macobeba é construída nas crônicas de José Mathias, no texto de Mário de Andrade, nos escritos de Graciliano Ramos e no livro de Manuel Cavalcanti Proença, a fim de constatar eventuais afastamentos e aproximações.

\section{1. “UMA SÉRIE DE REVELAÇÕES SENSACIONAIS SOBRE UM TAL MACOBEBA, BICHO HORROROSO QUE ESTÁ APARECENDO NAS PRAIAS DO SUL" (A PROVÍNCIA, 7 DE ABRIL, DE 1929)}

Macobeba vem a lume em 7 de abril de 1929, na primeira de uma série de crônicas do periódico pernambucano $A$ província. Dos 28 textos que tratam do monstro - de suas aventuras, de sua genealogia, dos efeitos despertados por ele nos leitores e nas crianças, das revelações acerca de sua origem mitológica e da sua origem como personagem, do fim da história, etc. - 26 foram escritos por José Mathias, modo "como se ocultava o senhor de 
engenho e escritor Júlio Bello, também autor, até 1930, de artigos firmados com o próprio nome e com outro pseudônimo: Jose Pinto Corte Real" (NASCIMENTO, 1966, p.233). Júlio Celso de Albuquerque Bello, o "agricultor sentimental", epíteto dado por Gilberto Freyre, foi "jornalista de oposição, deputado, presidente do Senado de Pernambuco, governador interino do estado" (FREYRE, 1987, p.181). Sua obra de maior destaque, Memórias de um senhor de engenho (1939), segundo Freyre: (1987, p.189-190):

uma contribuição valiosa para o estudo da história social de Pernambuco. O Pernambuco das últimas casas-grandes patriarcais. Retrata figuras que só os bons escritores de memórias sabem salvar do esquecimento em que as deixa a outra história: a oficial; a dos sócios do Instituto; a dos historiadores solenes que apenas se interessam pelos homens públicos e pelas datas gloriosas: não enxergam nunca os parentes pobres dos heróis, às vezes tão cheios de interesse humano.

Júlio Bello, assinando com o pseudônimo de José Mathias modo como aqui será tratado - é o responsável majoritário pelos quadros de Macobeba que saem no periódico A província, uma vez que, de 28 textos, apenas dois não foram escritos por ele, mas por José Lins do Rego e Estevão Pinto - ambos analisados nos tópicos subsequentes. Para além dos três autores mencionados, Manuel Bandeira também participa da cocriação da personagem, ao desenhar o monstro, que acompanha quase todas as crônicas de Macobeba, como na figura 1; poucos são os textos sem o desenho, que ilustra a descrição de José Mathias:

Grande, muito grande, do tamanho de uma sucupira de meio século, com um extenso rabo metade de 
leão e metade de cavalo, quatro imensos olhos vermelhos como quatro grandes brasas vivas a flor da cara, aduncas unhas de "lobisomem", enorme cabeleira [...] de "Mãe-dagua", feroz como "João Galafoice", traiçoeiro e rápido como o "Pai do Mato", o Macobeba empunha uma imensa vassoura de grandes cordas resistentes de cruapé e devasta tudo por onde passa.

Anoitece muita vez num engenho junto a Camela do Sirinhaém e pela madrugada passa uivando noutros dos Confins de Rio Formoso com Água Preta.

As garruchas se escorvam e se penduram nos tornos dos mocambos de pindoba. Nos cantos das casas de palha os zagunchos de cinco palmos de folha e cinco metros de cabo luzem afiados para a investida ao bicho desesperado que há duas semanas passa incólume em todos os lugares. (MATHIAS, A província, 7 de abril de 1929) ${ }^{2}$

Há uma série de passagens semelhantes à supracitada, contando o que o monstro anda fazendo, o modo como ele está atormentando e apavorando os moradores das regiões, e os prejuízos sérios que está causando à localidade:

O Macobeba vive na zona ribeirinha do mar não se afastando dez léguas dos cômoros da praia.

O que come não se sabe ao certo.

Bebe a água salgada do mar e com tamanha sofreguidão a bebe que de quando em vez as vazantes da maré se adiantam de horas e descobrem-se na costa coroas de areia que jamais nenhum cataclismo descobriu.

[...].

2 Todas as citações retiradas de periódicos foram consultadas através de pesquisas na Hemeroteca Digital. In http://bndigital.bn.gov.br/hemeroteca-digital/. Acesso em 6.Nov.2018. 
O Macobeba está secando o mar e despovoando a terra firme com a sua imensa sede de tromba e a sua crua ferocidade de "Lobisomem".

Nossa Senhora proteja as criancinhas de cachos de cabelos louros, as meigas criancinhas das praias da maldade do estafermo.

Deus permita que "João Galafoice" que é ranzinza, birrento e teimoso venha do mar e o velho "Pai do mato" desça da floresta, que se ajuntem com as quatro maiores e mais ligeiras "caiporas" da mata virgem, com a "Mãe-dagua" e o "Lobisomem" e deem cabo do malvado para que fiquem as beiras de praia livres do Macobeba, do tamanho de uma sucupira de meio século com o seu grande rabo de leão e de cavalo e seus quatro grandes olhos arregalados e vermelhos como quatro imensas brasas vivas pegando fogo em tudo. (MATHIAS, $A$ província, 7 de abril de 1929)

Ou ainda, em termos de destruição:

Onde passa deixa o sinal e há quatro dias que não se descobre traços de sua passagem dali saindo em qualquer direção.

O Macobeba é como um judeu errante: semeia a desgraça no seu caminho. E a alma danada do fogo e da devastação.

É necessário caçá-lo com desespero.

Tiro não o mata, fogo não o queima, água não o afoga, mas é preciso acabar com o Macobeba (MATHIAS, A província, 11 de abril de 1929).

Há, também, passagens que ilustram peripécias, como:

Pela manhã de ontem apareceram no campo do Piranga quatro vacas de rabos arrancados e dois touros atolados até os chifres num pântano das 
circunvizinhanças ao pé de uma azinhaga que margeia num bosque de eucaliptos. Não foram encontrados os quatro rabos de vaca.

Parece que dali rumou ao morro do Arraial não se aproximando muito da grande estátua de Nossa Senhora.

$[\ldots]$.

Perto da vila operária da Casa Amarela para os lados da linha férrea do norte virou um mocambo de zinco invertendo a frente que à noite estava voltada para o sul e amanheceu voltada para o norte. Isto causou um verdadeiro assombro na zona ribeirinha e não se compreende porque artes do demônio Macobeba conseguiu tão extraordinário sortilégio sem que os moradores residentes da casa acordassem no ato da mutação e dele se apercebessem (MATHIAS, $A$ província, 21 de abril de 1929).

A longa série de extensas citações mostra o tom presente na maioria das crônicas de Macobeba. O monstro geralmente aparece causando confusão e deixando cenários de caos por onde passa, levando destruição a diversas regiões. No dia 1 de setembro de 1929, no entanto, José Mathias publica um texto inusitado: "Macobeba nunca existiu", relatando como ele teve alucinações e viu o monstro em meio a uma forte ressaca:

Amigos, durante aquelas terríveis 24 horas de sono vi Macobeba e aquelas horrendas tropelias todas num pesadelo. Vi e contei-vos nas minhas crônicas. Dr. Ulysses Pernambucano, o ilustre psiquiatra, a um cliente que na minha presença se lhe queixara de andar vendo em sono e até nas vigílias, animais pelos ares, disse-Ihe com brandura:

- Deixe de beber. Isso de animais em sonho e assim acordado é mau sinal. Você acaba dando-me 
trabalho lá para os lados da Casa Amarela. Deixe a bebida.

Macobeba foi o pesadelo de um alcóolatra inveterado e hereditário.

Perdoem-me, amigos. (MATHIAS, A província, 1 de setembro de 1929)

O final do monstro - depois desse texto não são narradas outras atividades de Macobeba - é inesperado, pois ao longo das crônicas não havia indicações de que a trama terminaria com um viés cômico, visto que Macobeba não era pintado de um modo engraçado. É possível afirmar que não havia comicidade na elaboração da imagem do bicho, a partir de uma análise da seleção lexical utilizada na caracterização dele.

Desse modo, em termos de substantivos usados para tratar do monstro, percebemos, em ordem quantitativa de ocorrência, palavras como "lobisomem" (24 vezes), "fantasma" (18), "bicho" (10), "abantesma" (7), "monstro" (5), "avejão" (4), "demônio" (3), "estafermo" (3), "ente", "malfeitor", "animal" e "besta" (todos sendo usados apenas 1 vez), além dos adjetivos substantivados: "desgraçado" e "malvado" (ambos ), "desadorado" e "encourado" (ambos 1). Já em termos de adjetivos, temos "horrível" e "terrível (ambos utilizados 6 vezes), "maldito" (4), "horroroso" e "diabólico" (ambos 2), e "fantástico", "danado", "monstruoso", "invencível" e "desadorado" (todos usados apenas 1 vez). Ademais, por duas vezes o narrador caracteriza o modo de surgir de Macobeba como "aparecer como um demônio", e menciona, uma vez, certos "vapores de enxofre" deixados pelo monstro por onde passa, construindo, assim, a imagem do bicho como algo demoníaco, o que atinge seu 
ápice com a recorrência da necessidade e da impossibilidade de matá-lo: "[t]iro não o mata, fogo não o queima, água não o afoga mas é preciso acabar com o Macobeba", espécie de leitmotiv, que aparece 6 vezes ao longo das crônicas, geralmente após um cenário de destruiç̧ão de Macobeba.

Tais escolhas lexicais, portanto, constroem a imagem de Macobeba a partir do campo semântico do medo, uma vez que o narrador não utiliza substantivos e adjetivos que não estejam ligados ao temor, à destruição, ao horror, de modo a construir e elaborar uma figura monstruosa e assustadora, selecionando as palavras que se inserem adequadamente nesse campo.

Assim, o monstro é pintado de maneira assustadora, o que fica ainda mais evidente, quando os textos de José Mathias são contrastados com os de José Lins do Rego e Estevão Pinto, publicados na mesma coluna, analisados na sequência.

\section{1. "ESTÁVAMOS SEM UM LOBISOMEM, UM DESSES TERRORES TÃO NECESSÁRIOS À IMAGINAÇÃO DO POVO" (REGO, A PROVÍNCIA, 7 DE JUNHO DE 1929)}

Como mostrado na seção anterior, das 28 crônicas sobre as peripécias de Macobeba, 26 foram escritos por José Mathias (Júlio Bello), uma por José Lins do Rego e outra por Estevão Pinto. Em 7 de junho de 1929, Macobeba aparece nas páginas do periódico, sob a pena de José Lins do Rego.

Desde a chamada na página do periódico, o modo de construir a personagem já difere do modo de José Mathias. Enquanto nos textos deste, as chamadas adiantavam algumas atrocidades do monstro, no texto de José Lins do Rego, a chamada assegura: "Macobeba é 
um ótimo professor de corografia" (REGO, A província, 7 de junho de 1929). Ao apontar para essa função inusitada da personagem, uma vez que ela vinha sendo construída de modo a causar medo, o autor de Fogo morto dá o tom e o modo de conceber e figurar a personagem no seu texto, como na seguinte passagem:

O aparecimento desse bicho terrível nascido em praias do sul de Pernambuco veio mesmo a propósito.

Estávamos sem um lobisomem, um desses terrores tão necessários à imaginação do povo.

[...], Macobeba poderia continuar a fazer o diabo, por ali a fora, e ficaria a um canto, como têm ficado outros Macobebas, se não fosse seu biógrafo, tão informado de suas proezas, tão conhecedor dos lugares por onde tem o monstro andado. Numa brincadeira o sr. Mathias me obrigou a conhecer a geografia de Pernambuco, pedaço por pedaço. Cada desgraça que o Macobeba arranje é um novo rio que eu conheço, um engenho que me entra na memória, um lugar de nome pitoresco que nunca mais a gente se esquece (REGO, 1929)

Ao garantir que o bicho terrível "veio mesmo a propósito", uma vez que terrores são "necessários à imaginação do povo", e contar como, de modo indireto, as aventuras de Macobeba ensinam geografia, ele mostra uma utilidade da personagem, além de simplesmente apavorar. Ainda que use o vocábulo "brincadeira" para se referir às aventuras do monstro, José Lins não questiona a elaboração da figura no campo semântico do medo, ao mesmo tempo em que também não reforça isso, já que não narra novas tropelias. Curiosamente, apesar de contar que o monstro vem ensinando geografia a ele, isso não denigre ou impossibilita a capacidade de despertar o medo: 
Foi o deputado Carlos Pontes que em discurso, querendo se referir a um lugar perigoso, chamava-o de ninho do Macobeba. E nas camadas populares o lobisomem de Pernambuco está metendo um medo sério. Outro dia quiseram atribuir escassez de peixe na "Lagoa da Mangueba" a coisas do Macobeba. E um dia destes, voltava de um "football", em minha frente vinha uma moça de vestido muito curto. Uma senhora que estava à porta com umas visitas, com esse olho agudo que têm as mulheres para olhar os vestidos das outras, dizia para uma amiga: "É por isto que o Macobeba vem aí". Em Maragogi, município perto das terras donde saía Macobeba, há um verdadeiro terror entre os trabalhadores rurais. José Mathias contou que o bicho vinha descendo rumo sul e os pobres homens ficaram alarmados com a história. Contou-me um usineiro de lá o sr. Jorge Salles, que um de seus moradores lhe pedira as contas. Não queria ficar por ali com medo do bicho que vinha comendo tudo. (REGO, 1929)

Ainda no sentido de explorar a capacidade da personagem de despertar medo, Zé Lins dá o seu testemunho, mostrando justamente como isso é útil para ele e para sua vida familiar:

Mas onde Macobeba está mais temido e mais vivo é entre os meninos. Para mim, ele me foi uma salvação. Sobretudo para quem tem, como eu, menino pequeno e não sabe como arranjar cara de meter medo.

[...]. Entre os meus dois meninos esse retrato é capaz de liquidar com a vontade mais impertinente. E diga-se, de passagem, não há vontade mais decidida e mais firme que a de um menino que quer uma coisa. [...], o Macobeba. Deus há de me perdoar a imagem, caiu-me do céu. É só 
falar no nome do bicho e os meninos a amolecer a vontadezinha impertinente. [...]. Macobeba renovou para o mundo dos meninos essa coisa que muito pedagogo besta considera um mal: o medo. Macobeba é o gênio da destruição mais violento de quantos há por ai. Porque, repetindo uma palavra dos modernos, em matéria de destruir ele realiza uma "totalidade". Para mim ele foi um descanso. (REGO, 1929)

A longa citação ilustra perfeitamente o modo como José Lins do Rego refigura a personagem. Reconhecendo todos os seus atributos mais monstruosos que despertam medo, sem ser atingido por eles, o autor valoriza tal caracterização, uma vez que, de maneira bem pessoal, dá depoimentos e trata da utilidade do medo despertado pelo monstro. A seleção lexical usada por ele é bem curiosa, pois trata dos seus aspectos monstruosos, do ensino de corografia e da serventia do medo despertado por ele. Assim, há termos como "monstro", "bicho", "lobisomem", "diabólico", "violento", "gênio da destruição", "salvação", "descanso" e "ótimo auxiliar para as lições de corografia".

José Lins do Rego pinta Macobeba de uma maneira bem peculiar: ele é o monstro que desperta medo, útil na educação dos meninos, ao mesmo tempo em que em todas as suas andanças destrutivas ensinam a nomenclatura dos diferentes rios, regiões e localidades. Diferentemente da caracterização elaborada por José Mathias, cujo intuito é narrar as peripécias e ilustrar as atrocidades do bicho, despertando medo, José Lins do Rego em alguma medida dá relatos de como o medo do monstro vem funcionando e mostra utilidades da personagem, para além do apavoramento. 


\section{2. “COM TODA A CERTEZA, O MACOBEBA SERÁ UM DESDOBRAMENTO DE UM DOS MITOS SECUNDÁRIOS, A SABER, A IARA, O BOITATÁ, O SACI, O LOBISOMEM E O IPUPIARA" (PINTO, A PROVÍNCIA, 12 DE JULHO DE 1929)}

No dia 12 de julho de 1929, o responsável pela coluna de Macobeba é Estevão Pinto, um "[h]umanista, considerado um dos pioneiros da antropologia do Brasil [...] [que] teve uma relevante atuação como historiador, sociólogo, antropólogo e folclorista" (GASPAR, 2011). Possivelmente influenciado pela sua formação, o texto de Estevão é significativamente distinto dos escritos por José Mathias e do escrito por José Lins do Rego. Desde o princípio, a diferença é notória:

O macobeba - espécie de lobisomem malfazejo, aparecido ultimamente em Pernambuco - surgiu, portanto, num momento propício, que é o do período áureo do folclorismo nacional.

Antes, porém de falar sobre esse animal fantástico, vejamos até que ponto a natureza física é responsável pela origem dos mitos em geral. (PINTO, 1929)

Para além da não utilização de letra maiúscula no começo do nome da personagem, aqui se destaca também o tom adotado desde o princípio do texto, deixando claro que o autor se propõe a tratar de Macobeba como um produto do folclorismo nacional. No início do texto, já notamos que o monstro não terá suas peripécias narradas, nem os efeitos que causa nas pessoas comentados, de modo que Estevão Pinto se afasta do tom presente nas crônicas de José Mathias e na de José Lins do Rego. Em sua proposta de estudar e tentar resgatar as origens da personagem, Estevão parte, 
primeiramente, da ideia de que a natureza física é responsável por muitos mitos:

A natureza desperta, portanto, o instinto humano. É ainda a natureza que dá vestidura às ideias humanas. Assim nasceram os gigantes da mitologia germânica e os dragões da mitologia chinesa, isto é, nasceram para explicar uma natureza grandiosa e aterrorizadora, um ambiente de rios majestosos e negras florestas. (PINTO, A província, 12 de julho de 1929)

Na sequência, com um tom muito próximo da escrita acadêmica, marcada por citações, referências a variados estudos, menções a diferentes especialistas, Estevão continua sua argumentação acerca do modo como se originam os mitos, e, ao tratar do Egito e Babilônia, afirma:

Nada de Babilônia nem do Egito! Com o mesmo absurdo critério já se quis até derivar os nossos íncolas dos fenícios sob o pretexto de supostas afinidades linguísticas, quando todos nós sabemos que, sendo a estrutura individual uma só, à exceção de pontos superficiais, claro está que o órgão vocal humano "teria emitido sons idênticos em todos os idiomas, como ponto de partida para a formação das línguas particulares" (Afonso A. de Freitas). Há, enfim a mesma identidade de processo nas leis psicológicas da imaginação, isto é, todas as criações populares surgem em virtude da mesma uniformidade das leis da imaginação. (PINTO, 1929)

A longa passagem acima, transcrita à guisa de curiosidade, funciona como uma mostra do tom predominante no texto. Estevão Pinto faz uma série de análises, citações e explicações antes de tratar de Macobeba. Quando, finalmente, começa a tratar do monstro, 
seu intuito de pensar as origens dele, a partir do levantamento de diversas hipóteses e do estabelecimento de comparações, fica muito claro:

O macobeba, por alguns de seus característicos primordiais - quatro grandes olhos, dimensões gigantescas, uso de vassoura de fio de cruapé - não tem nenhum parentesco com o diabinho jurupari dos indígenas; por outro lado, o apego pelas zonas ribeirinhas tira-Ihe a probabilidade de se filiar ao grupo dos curupiras.

Com toda a certeza, o macobeba será um desdobramento de um dos mitos secundários, a saber, a iara, o boitatá, o saci, o lobisomem e o ipupiara.

[...].

Que o macobeba nada tem que ver com a iara ou o boitatá não é preciso demonstrar. Será, então, parente do lobisomem, que é uma das crenças mais importantes da mitologia sertaneja? Estamos em crer que não. (PINTO, 1929)

Com essa passagem fica evidente o modo como Macobeba é pintado por Estevão Pinto. Em nenhum momento há menção aos seus elementos assustadores, aos efeitos que eles despertam, ou a diferentes e curiosas utilidades do monstro. Aqui, Macobeba é apenas um objeto de estudo e análise em termos de folclore brasileiro. No meio de tantas análises, explicações e justificativas de origem, quando trata de Macobeba, Estevão garante:

Como o macobeba é um mito moderno, sofreu a influência alienígena - o rabo de leão, a vassoura (tirada das bruxas do além Atlântico), o poder de correr às léguas, de estar em lugares distantes 
uns dos outros quase ao mesmo tempo (o que é, talvez, um efeito da locomotiva, do automóvel, do telégrafo). Com o saci tem apenas a coincidência de ser sempre encontrado nos caminhos [...] a pregar peças a Deus e ao mundo; com o ipupiara é irmão apenas na tendência de procurar o elemento líquido e as zonas ribeirinhas.

O macobeba é um mito imaginado para explicar os desastres materiais, que crescem à proporção da multiplicidade das conquistas e das invenções humanas. (PINTO, 1929)

Diferentemente de José Mathias (Júlio Bello), que buscava narrar as peripécias e atrocidades da personagem, ou de José Lins do Rego, que, sem perder de vista os aspectos monstruosos da figura e seus efeitos, mostra diferentes reações a ela, Estevão propõe-se a analisar a origem folclórica e mitológica da personagem. Ainda que mencione os elementos que a compõem, o autor o faz apenas para ilustrar e explicar suas hipóteses de análise. Em nenhum momento ele se propõe a narrar mais casos, ou explorar efeitos do aspecto monstruoso; Macobeba funciona apenas como um tema de análise.

\section{2. "INDA AGORA ESTÁ APARECENDO NO SUL LITORÂNEO DE PERNAMBUCO UMA ASSOMBRAÇÃO MUITO SIMPÁTICA" (ANDRADE, DIÁRIO NACIONAL, 3 DE MAIO DE 1929)}

O texto "Macobeba" de Mário de Andrade sai originalmente no dia 3 de maio de 1929, na coluna "Táxi" do periódico Diário Nacional, publicado ao mesmo tempo em que as crônicas de José Mathias. Nele o autor de Macunaíma faz referências explícitas aos textos pernambucanos, como na descrição do bicho, ficando evidente que se trata do mesmo animal: "É o chamado Macobeba, bicho-homem dum tamanho arranha-céu, gostando muito de beber água de mar 
e queimar terras"; "[n]o corpo o Macobeba é apenas um exagero. Mas não tem nada de original. Gigante feio mas cabeça, tronco e membros. Cabelo em pé, quatro olhos e rabo metade de leão, metade de cavalo" (ANDRADE, 1929).

Apesar de descrever igualmente a aparência do monstro, a crônica não se propõe a contar outros feitos dele, pois, logo no começo do texto, Mário já emite sua opinião acerca de assombrações: "[n]o geral tenho um pouco de fadiga de assombrações. Acredito nelas e sei que são um fornecimento contínuo de sensações intensas, porém, me cansa a precariedade plástica que elas têm. Falta invenção pra elas duma forma exasperante" (ANDRADE, 1929 - grifos nossos). Assim, ainda que diga acreditar em assombrações, o autor de Pauliceia desvairada tece críticas a elas em termos de ausência de inovação e de novidades, estendendo tal opinião também a Macobeba: "[n]o corpo o Macobeba é apenas um exagero. Mas não tem nada de original [...]. Faz o que no geral fazem todas as assombrações desse gênero: assusta, mata, prejudica" (ANDRADE, 1929 - grifos nossos) e continua:

Só teve até agora uma deliciosa prova de espírito: carrega sempre uma vassoura de fios duros maravilhosamente inútil. Não serve-se dela pra nada. Ora por que será que o Macobeba traz uma vassoura na mão?

Muito provavelmente essa vassoura é uma reminiscência daquelas bruxas que montavam cabos da tal quando partiam pras cavalhadas do Sabát. Muito provavelmente. Porém a grandeza do Macobeba está em trazer a vassoura inteira e não se servir dela pra nada. Nisso, reside a simpatia do grande monstro. (ANDRADE, 1929) 
As passagens transcritas mostram a diferença de tom entre o texto de Mário de Andrade e os de José Mathias, o que se evidencia a partir da seleção lexical e das estruturas usadas por Mário para construir a imagem do monstro. Os substantivos são: "assombração", "bicho-homem", "gigante" e "monstro", e os adjetivos: "sedentíssimo", "feio", "simpática", "sedento" e "grande", todos usados apenas uma vez. Assim, enquanto nos textos de José Mathias há vocábulos e frases que remetem ao medo e ao perigo, Mário de Andrade não segue a mesma linha, e usa palavras que não trazem a mesma carga semântica, pintando, inclusive o monstro de maneira irreverente e irônica, ao chamá-lo de "assombração muito simpática" ou assegurar que "[n]isso reside a simpatia do grande monstro" (ANDRADE, 1929).

Nesse sentido, lembrando que a construção da imagem é uma relação entre um "Eu" que se revela a partir de um "Outro" (PAGEAUX, 2011), fica muito claro o que o narrador - o Eu objetiva criticar as assombrações e ironizar o modo como elas são construídas, tomando Macobeba - o Outro - como o exemplo, para, na sequência, usar uma série de clichês ligados a histórias de assombrações e finalmente construir a sua:

Só uma vez na vida estive em contato... objetivo com uma assombração [...]. Minha tia agonizava na casa pegada e nós [...] tínhamos sido alojados no vizinho para evitar bulha à chegada geralmente solene da morte [...]. De repente, da porta da copa surgiu no ar um pano grande bem branco [...]. Hoje, quanto mais friamente analiso as lembranças mais me convenço de que não era lençol não. Era um pano. Ou, por outra: nem era um pano exatamente, era um ser humano, disso estou convencidíssimo, 
porém desprovido de forma humana e possuindo a consistência e o provável aspecto físico de um pano. Surgiu no ar, atravessou em passo de transeunte o ar da sala, desapareceu no corredor escuro. Eu vi. Todos vimos ao mesmo tempo. [...]. Então fomos chamados pra chorar. (ANDRADE, 1929)

Assim, a partir da análise lexical e da ironia destinada a Macobeba, percebemos que os recursos utilizados para construir a imagem do monstro são bastante distintos dos usados nas crônicas de José Mathias, uma vez que objetivam (e alcançam) resultados e efeitos diferentes.

\section{3. "ERA MACOBEbA. PElO MENOS dizem QUE eRA MACOBEBA. QUE EU, PARA FALAR COM FRANQUEZA, NÃO ACREDITO MUITO NELE" (RAMOS, 2013, P.100)}

Nos dias 27 e 29 de abril de 1930, Graciliano Ramos, sob pseudônimo de Lúcio Guedes, publica dois textos no Jornal de Alagoas intitulados "Macobeba pré-histórico" e "Macobeba antigo", que saem décadas depois, em 2011, na coletânea de inéditos Garranchos. Os dois textos se completam, uma vez que o segundo funciona como continuação do primeiro. Em "Macobeba pré-histórico", Graciliano começa o texto com a construção da imagem de Alagoas no passado:

Antigamente Alagoas era um paraíso - a desordem, a confusão, o caos, todas as desgraças em fúria contra o pobre bicho desengonçado que penosamente começava a levantar a espinha e a caminhar, sem motivo aceitável, sobre as patas traseiras. [...].

Os bipedes alagoanos matavam-se incessantemente, na boa lei natural, e, como todos os bens pertenciam 
aos coronéis, a noção de roubo ainda não tinha aparecido. Circulava regularmente dinheiro falso. E essa coisa de tomar à força as mulheres e as filhas dos outros estava nos hábitos de quase todos os antigos mandões. (RAMOS, 2013, p.99 - grifos nossos)

O cenário construído de maneira irônica a partir da utilização de um tom saudosista para descrever uma série de atrocidades é justamente o meio que permite e estimula o surgimento de Macobeba:

Ora no meio dessa balbúrdia dos pecados surgiu um indivíduo animoso, resolvido a escangalhar tudo: um sujeito de "rosto carregado e barba esquálida, os olhos encovados e a postura medonha e má, e a cor terrena e pálida, cheios de terra (isto é exagero) e crespos os cabelos, a boca negra, os dentes"... de lobisomem.

Era Macobeba. Pelo menos dizem que era Macobeba. Que eu, para falar com franqueza, não acredito muito nele. Uma criatura positiva e constitucional, leitora de jornais, iluminada à eletricidade, não admite, é claro, as crenças que enchiam a alma dos homens antigos. Não acredito. $E$, para descrever Macobeba, recorri ao Camões: furtei uns pedaços do gigante Adamastor.

Macobeba nunca existiu. Ou antes existiu... Eu sei lá! Isto, como veem, se vai encrencando consideravelmente. Sinto que me não sairei de semelhante dificuldade. (RAMOS, 2013, p.99-100)

A longa citação transparece a dificuldade desse "Eu", o narrador, para elaborar a imagem do monstro, o "Outro" (PAGEAUX, 2011), uma vez que toma de empréstimo uma passagem de Camões para descrever Macobeba. A problemática da descrição continua: 
Houve talvez dois Macobebas. O primeiro, nascido numa idade heroica, tinha, como todos os heróis que se respeitam, uma existência subjetiva; o segundo, atual e bacharel, é um ser de carne e osso, como qualquer um de nós. Julgo que este foi pouco a pouco tomando o lugar daquele, até confundirse com ele e, de longe, parecerem formar os dois um todo indivisível. Tentemos separá-los. (RAMOS, 2013, p.100)

Conforme a incerteza, que justifica a dificuldade da descrição, se desfaz, o narrador começa a trabalhar com a fusão de dois Macobebas, sendo o primeiro uma espécie de herói, de figura mítica, e o segundo, um homem como outro qualquer. A relação entre ambos atinge o ápice no fim do primeiro texto - "Não era. Mas os outros pensaram que era. E o homem se transformou definitivamente em Macobeba" (RAMOS, 2013, p.101) - e se desenvolve plenamente em "Macobeba antigo", cujo primeiro período é: "[t]endo-se tornado Macobeba para todos os efeitos, o indivíduo a que nos referimos ficou sendo um grande homem" (RAMOS, 2013, p.103). Assim, a relação entre os dois Macobebas evidencia o tom alegórico dos textos, uma vez que fundir uma figura humana a um monstro ao ponto de a pessoa se tornar própria a besta é uma maneira de criticar e atacar alguém e suas atitudes, o que fica muito claro na sequência:

Macobeba sorria. Alagoas macobebizou-se. Da capital aos mais remotos sertões fervilhavam bichos destruidores, de incisivos aguçados e caninos enormes, que estragavam, sem cerimônia, o que iam encontrando. Uns devoravam com avidez. Outros se contentavam roendo modestamente, mas coisa que lhes caísse entre as garras era coisa roída. (RAMOS, 2013, p.104) 
Ainda que o narrador graciliânico não use substantivos ou adjetivos que remetam explicitamente ao campo do medo ou da monstruosidade, como faz José Mathias, a força do uso alegórico de Macobeba permite, justamente, que se pinte um cenário de destruição e de caos, do qual o monstro sai impune e vencedor:

Macobeba, resplandecente, mostrava o forro das algibeiras e sorria. Fundaram-se asilos, abriramse estradas, derramou-se gasolina - a família de Macobeba engordava e era feliz. Descobriu-se que havia no interior, entre os amigos de Macobeba, uma quantidade razoável de assassinos e ladrões de cavalos. Era grave. Começaram sussurros. Que diabo! Teriam trocado o Macobeba? A coisa assim não prestava, era necessário fazer outra.

Macobeba continuava a sorrir.

$[\ldots]$.

E Macobeba sorria. Sorriu sempre. Ultimamente sorria desconfiado. Mas sorria. E aqui termina a história de Macobeba antigo. (RAMOS, 2013, p.104)

Fica muito evidente, então, como a construção do Macobeba de Graciliano Ramos difere significativamente da de José Mathias, ao não pintar a imagem do monstro usando uma seleção lexical voltada para o campo semântico do medo, e também se afasta da de Mário de Andrade, ao não optar por um trato irônico da assombração. Entretanto, a construção alegórica da imagem de Macobeba, com um viés crítico, só é possível pela apropriação e reutilização dos aspectos monstruosos e negativos anteriormente associados à besta. 


\section{4. "VOFAVOFE, MEU CARO. O PRESIDENTE NÃO É DAQUI, É DO ESTRANGEIRO. SEU NOME É MACOBEBA" (PROENÇA, 1990, P.78).}

Em 1960, já consagrado por textos críticos acerca da literatura brasileira, como Roteiro de Macunaíma, Manuel Cavalcanti Proença escreve Manuscrito holandês ou a peleja do caboclo Mitavaí com o monstro Macobeba, claramente inspirado em Macunaíma - em termos de herói-protagonista que experimenta aventuras muito diversas, lendas, criaturas folclóricas, estruturação da trama, entre outros. Ainda que tanto Mitavaí quanto Macobeba estejam presentes no título, aquele aparece desde o primeiro capítulo da trama, enquanto o segundo é mencionado pela primeira vez apenas no capítulo XIII:

- Vofavofe, meu caro. O presidente não é daqui, é do estrangeiro. Seu nome é Macobeba, não conheço. Agora recebi uma bolsa de aperfeiçoamento e pretendo conhecer a terra do chefão. Dizem que é difícil falar com ele. Tem muitos serviços em todo o mundo e muitos ajudantes. Mas estou disposto a ser um grande na Vofavofe. Vale a pena, dinheiro à vontade, um automóvel do último tipo, boas mulheres... É o meu sonho... Veja lá... (PROENÇA, 1990, p.78)

A "VOFAVOFE (Vou Fazer Você Feliz, Colonizadora S/A)" (PROENÇA, 1990, p.79) é uma empresa gigantesca, um monopólio, que controla, domina, explora e artificializa todos os recursos dos lugares; não há possibilidade de escapar ou de sobreviver às práticas predatórias, apresentadas como inovação, conforto e utilidade. Como a primeira aparição de Macobeba na trama é na função de presidente da Vofavofe, sua imagem é inicialmente 
construída como a de um executivo, uma vez que os substantivos usados para se referir a ele são "presidente" e "chefão". Apenas no capítulo XX, a partir de uma cantiga popular, Macobeba reaparece, agora sendo caracterizado de outra maneira, como explicam Sérgio Motta e Luiza dos Santos:

O monstro Macobeba é resgatado da esfera das crenças populares, ainda que não seja esse o ponto fulcral da narrativa. Há uma transposição de significados no decorrer de sua linha biográfica que o entrelaça ora aos valores sociais e econômicos da região do sertão, como explorador, ora ligado mais fortemente às linhas oriundas da oralidade, em que sua presença é marcada pela constante do assombro, pelo poder de sugar as águas e provocar mortes. (MOTTA; SANTOS, 2008, p.3)

Há, portanto, no livro, a princípio, duas caracterizações de Macobeba, já que a datar do capítulo XXIX a imagem dele vai sendo construída a partir de referências explícitas às crônicas de José Mathias, como: "Macobeba tinha aparecido na praia do mar, bebia água à ufa e fazia aparecer coroas altas em lugares onde antes zinga não achava areia preta para se firmar. Os jornais contavam. Mitavaí começou a ficar preocupado" (PROENÇA, 1990, p.159); "[a] coisa teve início com um telegraminha e veio caminhando rapidamente da quarta página para as manchetes. Macobeba era um flagelo, gigante antropófago, bebedor de água do mar. Com uma vassoura enorme que não servia para nada" (PROENÇA, 1990, p.161).

Assim, conforme Macobeba vai sendo pintado como monstro, uma vez que suas atitudes representam perigo e destruição para a localidade, como representavam nas crônicas de José Mathias, Mitavaí resolve combatê-lo. Em uma batalha repleta de elementos 
mágicos e de figuras folclóricas, que auxiliam o herói, quando são enviadas para ajudá-lo, ou são assassinadas por ele, quando estão dispostas a matá-lo por causa de boatos que vinham denegrindo sua imagem - "Macobeba andava de rio acima levantando falso, fazendo enredo, espalhando mentira dele. Dizendo que Mitavaí andava faltando a vergonha a mulher casada e moça donzela, que ia acabar com o respeito de filho para pai, que mulher ia ser vendida" (PROENÇA, 1990, p.169) -, ele faz com que a besta dê origem a outro animal:

[n]em bem tinha desocupado o beco, o Monstro deu um estouro e se virou em labaredas grandes que até queimaram o bico de um japu esvoaçando perto. Das cinzas de Macobeba nasceu uma coisa que foi voando para o alto. Mitavaí ainda deu sete flechadas com a sarabatana, mas não fez efeito e o bicho bateu asas para o Polo Norte. (PROENÇA, 1990, p.178)

Após matar o monstro, Mitavaí se torna o herói do lugar e começa a ser cotado para ocupar cargos relevantes na vida política, o que Ihe traz alguns inimigos. Estes, por sua vez, começam a apresentar outra faceta do monstro, possivelmente com o intuito de desmerecer o herói:

E de fato, falou muito mais do que Mitavaí poderia imaginar. [...]. "Só a politicagem corrupta dos Orembaés, retardados mentais, mentia ao povo, desvirtuando o sacerdócio da imprensa, apresentando Macobeba como monstro. Muitos países deviam seu progresso atual à compreensão dos políticos adiantados que haviam aceitado a colaboração desinteressada de Macobeba na dragagem dos rios, na formação de ilhas artificiais, 
no desenvolvimento do azeite de peixe como combustível".

Continuou dias e dias insistindo, aumentou a tiragem do jornal, fundou clubes de Regeneração Nacional. Clamava que o povo não devia consentir que Mitavaí fosse eleito, porque um assassino não podia chegar à mais alta magistratura. Matara Macobeba, era certo, mas com isso cometera um novo crime, muito maior que o primeiro, pois o Monstro, apresentado como inimigo do país, era generoso e pacífico. Se bebia as águas do mar, formava ilhas para o cultivo dos cereais; quando se banhava, com o corpo enorme dragava os rios, incrementando e facilitando a navegação fluvial. Macobeba queria apenas o direito de viver no país, concorrendo com os nativos para o seu progresso, tranquilamente, pacificamente. (PROENÇA, 1990, p.204-205 - grifos nossos)

A longa passagem, ainda que seja uma tentativa de ataque a Mitavaí, é relevante para se pensar em uma terceira caracterização de Macobeba. No primeiro momento, ele surge como "presidente" e "chefão" da "Vofavofe". Já no segundo, pintado como nas crônicas de José Mathias, é tratado majoritariamente como monstro, mas também por outros substantivos, "flagelo", "gigante" e "antropófago", além do adjetivo substantivado "bruto", de modo que suas atividades representam um perigo para a região e ele precisa ser combatido. No terceiro momento, como na citação acima, ele não deixa de ser chamado de monstro, no entanto, é um monstro "generoso e pacífico", perdendo seu aspecto ameaçador.

Em suma, o Macobeba de Cavalcanti Proença é figurado de três maneiras distintas relacionadas ao longo da obra. Ainda que esses modos não dialoguem com a construção feita por Mário de 
Andrade, ou com a de Graciliano Ramos, é inegável a relação deles com a maneira como Macobeba era pintado nas crônicas de José Mathias, a partir da utilização de uma seleção lexical semelhante, que resulta numa caracterização bem próxima, ou, ainda, pela menção à aparição do monstro através dos jornais.

\section{CONCLUSÃO}

As análises realizadas apresentam diferentes refigurações de Macobeba. Para além do seu surgimento em abril de 1929, por José Mathias (Júlio Bello), o monstro reaparece - na mesma coluna nos textos de José Lins do Rego e Estevão Pinto; no texto de Mário de Andrade, em maio do mesmo; em dois escritos de Graciliano Ramos, em 1930; e no livro de Cavalcanti Proença, em 1960, além de diversas manifestações no imaginário popular. Tais reaparições caracterizam a sobrevida da personagem:

Refiro-me ao conceito de sobrevida e aludo, deste modo, àquelas práticas em que reconhecemos a personagem como entidade refigurada. Isso acontece por vezes em contextos e em narrativas literárias, por exemplo, na paródia, na citação ou na incorporação de uma personagem numa narrativa subsequente àquela em que originalmente existiu. (REIS, 2017, p.129)

Desse modo, o monstro Macobeba é um exemplo de refiguração de personagem no Modernismo brasileiro. Porém, tantas refigurações, em contextos distintos, geram uma série de diferenças entre as reaparições, perceptíveis a partir de uma análise lexical detalhada, como a imagológica, possibilitando que as comparações sejam estabelecidas. 


\section{REFERÊNCIAS}

ANDRADE, Mário (1929). “Macobeba”, Diário Nacional, São Paulo, (562), mai., p.3. FREYRE, Gilberto (1987). "Júlio Belo, agricultor sentimental”. In: . Perfil de Euclides e outros perfis. Rio de Janeiro: Record,. p.181-190.

GASPAR, Lúcia. Estevão Pinto (2018). Pesquisa Escolar Online, Fundação Joaquim Nabuco, Recife. In http://basilio.fundaj.gov.br/pesquisaescolar/. Acesso em 5.Dez.2018.

MATHIAS, José (1929). "Macobeba é mais feio que o cão", A província, Pernambuco, abr., (80), 3.

(1929). "O Macobeba é como o 'judeu errante'”, A província, Pernambuco, abr., (83), 3.

(1929) "Macobeba saiu de novo a fazer tropelias", A província, Pernambuco, abr., (92), 3.

(1929). "Macobeba nunca existiu", A província, Pernambuco, Set., (201), 3-4.

MOTTA, Sérgio Vicente; SANTOS, Luiza Aparecida dos (2008). "Cavalcanti Proença: quadros de Mitopoética". In Anais eletrônicos do XV Congresso Internacional da Abralic. São Paulo: USP. In

http://www.abralic.org.br/eventos/cong2008/AnaisOnline/simposios/pdf/007/ LUZIA_SANTOS.pdf. Acesso em 6.Nov.2018.

NASCIMENTO, Luiz do (1966). História da imprensa de Pernambuco (1821-1954). II. Pernambuco: Imprensa Universitária/Universidade Federal de Pernambuco. In http://www.fundaj.gov.br/geral/200anosdaimprensa/historia_da_imprensa_ v02.pdf. Acesso em 3.Nov.2018.

PAGEAUX, Daniel-Henri (2011). “Elementos para uma teoria literária: imagologia, imaginário, polissistema". Katia A. F. de Camargo (Trad.). In: Musas na encruzilhada: ensaios de literatura comparada. Frederico Westphalen (RS)/São Paulo/Santa Maria (RS): EdURI/Hucitec/ EdUFSM. p.109-127.

PINTO, Estevão (1929). "Qual é a família do Macobeba?", A província, Pernambuco, , jul., (158), 2.

PROENÇA, Manuel Cavalcanti (1990). Manuscrito Holandês ou A Peleja do 
Caboclo Mitavaí com o Monstro Macobeba. 5.ed. Rio de Janeiro: Civilização Brasileira.

RABATEL, Alain (2016). "Introdução Geral: por uma análise enunciativa dos pontos de vista na narração". In: Homo narrans: por uma abordagem enunciativa e interacionista da narrativa. São Paulo: Cortez Editora. p.15-55.

RAMOS, Graciliano (2013) “Macobeba pré-histórico". In: . Garranchos. Thiago Mio Salla (Org.). 2.ed. Rio de Janeiro: Record. p.99-102. (2013). Macobeba antigo. In: - Garranchos.Thiago Mio Salla (Org.). 2.ed. Rio de Janeiro: Record. p.103-105.

REGO, José Lins do (1929). "Macobeba é um ótimo professor de corografia”, A província, Pernambuco, jun., (130), p.3.

REIS, Carlos (2018). Dicionário de Estudos Narrativos. Coimbra: Edições Almedina. (2017). Para uma teoria da figuração. Sobrevidas da personagem ou um conceito em movimento. Letras de Hoje, Porto Alegre, abr.-jun ,52, (2), 129-136. SALLA, Thiago Mio (2016). Jornal de Alagoas e a revista Novidade: política e letras na capital alagoana. In: . Graciliano Ramos e a Cultura Política: mediação editorial e construção do sentido. São Paulo: Editora da Universidade de São Paulo/ Fapesp. p.92-111.

\section{ANEXO}

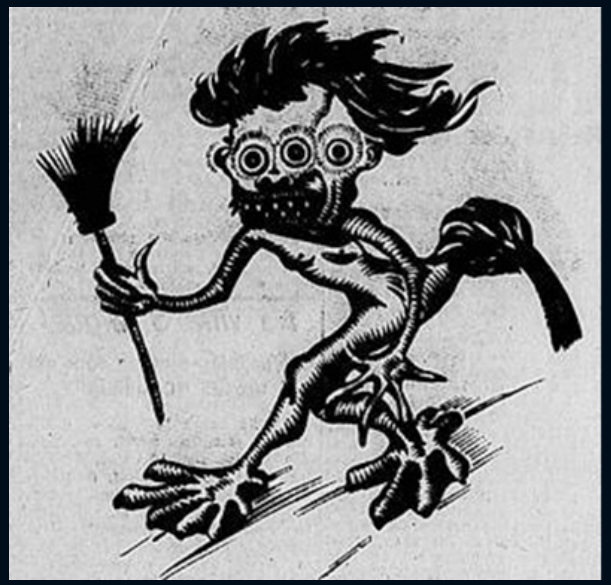

Fig. 1: Macobeba desenhado por Manuel Bandeira 


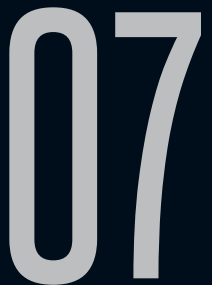

\section{AINULINDALË, THE LORD OF THE RINGS AND LOTRO: ABOUT TIME}

Lis Yana de Lima Martinez (UFRGS)

Recebido em 20 set 2018. Lis Yana de Lima Martinez é Doutoranda em Estudos Aprovado em 10 mar 2019. de Literatura da UFRGS. Atua na área de teoria, crítica e comparatismo tendo sua pesquisa voltada aos estudos intermidiáticos, intertextuais e interdisciplinares.

Abstract: According to Physics (HAWKING, 2017), time originated at the Big Bang. According to some religions, time originated at the moment God created the universe. Arda's time originated with the music sung by the Ainur and the counting of the days begun with Anar. In the following, I would like to offer a series of thoughts on the phenomenon of time comparing The Lord of The Rings Online (Lotro), released by Turbine Inc. and now maintained by Standing Stone Games, to Tolkien's Arda. Also, I would like to introduce the idea that while time is originated both by the wonderful beings Ainur and Anar in the book, the player is the wonderful being that rules her/his own present time in Lotro. To do this, I proceed via a brief account of Stephen Hawking's and game researchers' considerations about time. I propose that even in their differences the dialogue established between the media (literature and video game) is successful. More specifically, I suggest that each medium has its particularities however from their dynamic dialogue fruitful intermediatic creations may emerge.

Keywords: Time, ainulindalë, Tolkien, Lotro. 
Resumo: Segundo a Física (HAWKING, 2017), o tempo se originou no Big Bang. Segundo algumas religiões, o tempo se originou no momento em que Deus criou o universo. O tempo de Arda se originou com a música cantada pelos Ainur e a contagem dos dias foi iniciada com Anar. A seguir, gostaria de oferecer uma série de reflexões sobre o fenômeno do tempo comparando O Senhor dos Anéis Online (Lotro), lançado pela Turbine Inc. e agora mantido pela Standing Stone Games, para a Arda de Tolkien. Além disso, gostaria de apresentar a ideia de que enquanto o tempo é originado pelos maravilhosos seres Ainur e Anar no livro, o jogador é o ser maravilhoso que governa seu próprio tempo presente em Lotro. Para fazer isso, procuro por meio de uma breve descrição das considerações de Stephen Hawking e de pesquisadores de jogos de videogame sobre o tempo. Proponho que, mesmo em suas diferenças, o diálogo estabelecido entre as mídias (literatura e videogame) é bem-sucedido. Mais especificamente, sugiro que cada mídia tenha suas particularidades, mas que, a partir de seu diálogo dinâmico, podem surgir criações intermediárias frutíferas.

Palavras-chave: Tempo; ainulindalë; Tolkien, Lotro.

\section{INTRODUCTION}

The processes of adaptation and remediation of a literary work can be debated in many ways by the user (reader, spectator, player, etc.). According to intermedia studies, besides user's interpretations, scholars must explain the processes of dialogue without promoting value judgment. This means to understand that there are differences in the way each medium tends to produce its plurality of meanings. In a way that is appropriate to the circumstances, Linda Hutcheon (2013) explains that a story shown is not the same as a story told, 
and none of them is the same as a story of which you participate or with which you interact:

To tell a story, as in novels, short stories, and even historical accounts, is to describe, explain, summarize, expand; the narrator has a point of view and great power to leap through time and space and sometimes to venture inside the minds of characters. To show a story, as in movies, ballets, radio and stage plays, musicals and operas, involves a direct aural and usually visual performance experienced in real time. (HUTCHEON, 2013, digital source)

Accordingly, the effect of reading will not be the same as watching or interacting. Among new media, digital media value interactivity. Becoming players in a product from a remediation process the users have the power to weave the story of their character (avatar) and interfere within the narrative(s). Pursuant to video games, a player is a user who projects herself/himself into a virtual world and has in her/his character the extension of her/his self. Considering the neurological level, the psychosomatic stimulus "allows us to feel our own body extending into the virtual environment through a kind of virtual tool-use" while the audiovisual stimulus "activates our own motor system as a response to observed motor systems" (GREGERSEN, GRODAL, 2009, p.69). The process develops "incarnation or personification", i.e.,

when the player moves their body and an avatar moves in a corresponding way. The thumb pushes forward and the avatar walks [...]. My actions in the natural world extend into a virtual space. [...] Interactivity in games exhibit the same rhythm of the stable and precarious and it is this need that 
allows room for authorial intent (DEEN, 2011, digital source).

"Interactive Fiction" (JUUL, 1998), in which Massively Multiplayer Online Role-playing Games (MMORPGs) are structured, is an attempt to combine games and fantastic narratives. According to Juul (1998), the combination of both media is "usually described as the best of both worlds, where the reader/player deeply concentrated can participate in a story that unfolds in new and ever more interesting patterns".

In the following, I would like to offer a series of thoughts on the phenomenon of time comparing The Lord of The Rings Online (Lotro), released by Turbine Inc. and now maintained by Standing Stone Games, to Tolkien's Arda. To do this, I will proceed via a brief account of Stephen Hawking's and game researchers' considerations about time. I propose that despite the differences between the two media, the dialogue established between literature and video game is successful. More specifically, I will suggest that each medium has its particularities however from their dynamic dialogue fruitful intermedia creations may emerge.

I believe it is important to note that, for purposes of this text, Arda was considered an existing world, within its fantastic universe. Thus, all the descriptions found in The Silmarillion have been considered and applied in all their technicalities. Therefore, The Silmarillion was considered not only as a fabularium but as an expression of the truth concerning the cosmological genesis of Arda. 


\section{AINULINDALË}

At first, Eru llúvatar was the One, until from his thoughts he created the Ainur, the Holy Ones. Then,

they sang before him, and he was glad. But for a long while they sang only each alone, or but few together, while the rest hearkened; for each comprehended only that part of the mind of Ilúvatar from which he came, and in the understanding of their brethren they grew but slowly. [...] Then Ilúvatar said to them: 'Of the theme that I have declared to you, I will now that ye make in harmony together a Great Music. And since I have kindled you with the Flame Imperishable, ye shall show forth your powers in adorning this theme, each with his own thoughts and devices, if he will. But I will sit and hearken, and be glad that through you great beauty has been wakened into song.' (TOLKIEN, 2017, digital source)

When the song came to its end, Ilúvatar rose and walked away from where the Ainur had always remained since their creation, and they accompanied him. When entering

the Void, llúvatar said to them: 'Behold your Music!' And he showed to them a vision, giving to them sight where before was only hearing; and they saw a new World made visible before them, and it was globed amid the Void, and it was sustained therein, but was not of it. And as they looked and wondered this World began to unfold its history, and it seemed to them that it lived and grew (TOLKIEN, 2017, digital source)

This world was Arda and what enveloped it was Ëa, the universe of everything that exists. And the world created by Tolkien has undergone several transformations over the years. Won and lost 
continents, aged and saw great wars, just like our world. However, Arda underwent a structural transformation that obeys only the laws of llúvatar and that are not in the history of the Earth.

The Silmarillion tells that on an island on the Great Sea, between Aman and the Middle-earth, created by the Edain, there was Númenor. However, as a punishment, the island was destroyed when the Númenóreans rebelled and dared to sail towards Aman, the continent of Valinor, going against the law of the Valar by Melkor's influence.

With the destruction of Númenor, Arda, which was flat, became round. Aman was removed from the world and new lands and continents were created east and west of Middle-earth. Karen Wynn Fostand, the cartographer, comments in her cartographic study that

the consideration of whether this world was round or flat is inescapable for the cartographer attempting to map a world. One reference strongly indicated that Arda was originally flat: At the time of the fall of Númenor, Valinor was removed from Arda; then 'the world was indeed made round', although those permitted could still find the 'Straight Road' to Valinor. Prior to the change, the usage of the phrase 'Circle of the World' referred not to a planetary spherical shape, but rather to the physical outer limits or 'confines'. (FONSTAD, 1991, p.IX)

Also on that topic, Fonstad (1991) affirms that, despite being round, the maps of Arda provided by Tolkien in The Lord of the Rings describe it as flat, however, this would be more likely due to the fact that the author used to draw the maps with the intent of clarifying the world to his reader, than to represent the way its inhabitants 
perceived it. Yet, if they perceived Arda as flat, "few of us really perceive ourselves as living on a rounded surface, even though we know it is!" (FONSTAD, 1991, p.IX).

\section{A MATTER OF TIME}

According to Stephen Hawking (2017), Aristotle, who already considered the hypothesis of the Earth being round, thought that our planet was stationary and that the Sun, the Moon, the planets and the stars moved in circular orbits around it. The theory was perfected in II A.D. by Ptolemy, who proposed a complete cosmologic system in which Earth was in the centre, surrounded by eight spheres that included the Moon, the Sun, the stars and the five planets known at the time: Mercury, Venus, Mars, Jupiter and Saturn (HAWKING, 2017).

According to Hawking (2017), Aristotle believed in that because he felt, for mystical reasons, that the Earth was the centre of the universe and that the circular movement was the most perfect one, whereas the "Christian church" adopted Ptolemy's model as the image of the universe that was according to the Scriptures, for it had the great advantage of leaving plenty of space beyond the sphere of fixed stars for heaven and hell (HAWKING, 2017).

Thus did Tolkien. Be it for a religious preference of for an accidental choice, Arda seems to be the centre of Eä. Even if it might not be possible to affirm the centrality of this world by its locus in the universe, it might be possible to affirm its relevance once no Eru llúvatar or Ainur activity associated to it is presented. No other world, planet or independent celestial body is presented in Eä. 
The moment we are presented to Bilbo, in the Third Age, Arda is orbited by at least two other bodies that were created before the fall of Númenor: "Isil the Sheen the Vanyar of old named the Moon, flower of Telperion in Valinor; and Anar the Fire-golden, fruit of Laurelin, they named the Sun" (TOLKIEN, 2017, digital source). The bodies were guided by Tilion and Arien, respectively, and were created from the last breath of life of the trees Telperion and Laurelin which, before being destroyed by Melkor, once brought light into Valinor:

Isil was first wrought and made ready, and first rose into the realm of the stars, and was the elder of the new lights, as was Telperion of the Trees. Then for a while the world had moonlight, and many things stirred and woke that had waited long in the sleep of Yavanna. The servants of Morgoth were filled with amazement, but the Elves of the Outer Lands looked up in delight [...] Tilion had traversed the heaven seven times, and thus was in the furthest east, when the vessel of Arien was made ready. Then Anar arose in glory, and the first dawn of the Sun was like a great fire upon the towers of the Pelóri: the clouds of Middle-earth were kindled, and there was heard the sound of many waterfalls [...]. Now Varda purposed that the two vessels should journey in IImen and ever be aloft, but not together; each should pass from Valinor into the east and return, the one issuing from the west as the other turned from the east. Thus the first of the new days were reckoned after the manner of the Trees, from the mingling of the lights when Arien and Tilion passed in their courses, above the middle of the Earth. (TOLKIEN, 2017, digital source) 
Tilion, however, presented an inconsistency in following his route and in his speed and did not follow the designated path. Moreover, he attempted to get closer to Arien, being attracted by her sumptuousness, even if Anar burned him and the island of the Moon became singed. Therefore,

because of the waywardness of Tilion [...] and yet more because of the prayers of Lórien and Estë, who said that sleep and rest had been banished from the Earth, and the stars were hidden, Varda changed her counsel, and allowed a time wherein the world should still have shadow and half-light. Anar rested therefore a while in Valinor, lying upon the cool bosom of the Outer Sea; and Evening, the time of the descent and resting of the Sun, was the hour of greatest light and joy in Aman. But soon the Sun was drawn down by the servants of Ulmo, and went then in haste under the Earth, and so came unseen to the east and there mounted the heaven again, lest night be over-long and evil walk under the Moon. [...] But Tilion went with uncertain pace, as yet he goes, and was still drawn towards Arien, as he shall ever be; so that often both may be seen above the Earth together, or at times it will chance that he comes so nigh that his shadow cuts off her brightness and there is a darkness amid the day. Therefore by the coming and going of Anar the Valar reckoned the days thereafter until the Change of the World. (TOLKIEN, 2017, digital source)

According to Physics (HAWKING, 2017), time originated at the Big Bang. According to religion, time originated at the moment God created the universe. According to Arda's inhabitants, time originated with the music sung by the Ainur and the counting of the days begins with Anar. Considering that the trajectory of the celestial 
bodies has adapted to the new spherical shape after the Second Age, the counting of time is established, in regards to the passing of days, in a similar way to the one theorized by Aristotle and Ptolemy. That is, Anar and Isil would orbit that world in a circular trajectory. It cannot be determined if Anar would continue to rest in Valinor as it did when the world was flat. In fact, Aman's localization, from the moment it is removed from the world, becomes uncertain.

\section{LOTRO, AN INTERACTIVE FICTION}

In "On Fairy-Stories", J. R. R. Tolkien interprets fantastic universes and offers a proposition of characterization as a counterpoint to the real world, called "Primary World". Certainly, J. R. R. Tolkien theorized about the literary universe, but it seems like he introduces the understanding of experience site, which would be possible through video game: "Enchantment produces a Secondary World into which both designer and spectator can enter, to the satisfaction of their senses while they are inside; but in its purity it is artistic in desire and purpose" (TOLKIEN, 2012, digital source).

MMORPGs generate digital universes in which the programmers and the players find themselves connected. If, in literature, the Enchantment produces the Secondary World, in video games, the game (Secondary World) aims to be the path towards Enchantment. In the creation process of games, elements from other media are crossed and re-signified, provoking feelings and perceptions of the user who is used to a different interaction position in relation to the book and that, now, assumes a position of interaction, as an attempt of sensorial projection of the created universe. Thus, in this new world, it does not matter who practices the "Magic", even 
amongst the players and the non-player characters (NPCs), those who are controlled through the software's artificial intelligence and that give the Interactive Fiction a sense of continuity, "fay or mortal [...] its desire is power in this world, domination of things and wills" (TOLKIEN, 2012, digital source).

With the opposition between Primary and Secondary Worlds in mind, Jesper Juul, in the introduction of his book Half-Real, explains the "half-reality" present in the act of playing:

Half-real refers to the fact that video games are two different things at the same time: video games are real in that they consist of real rules with which players actually interact, and in that winning or losing a game is a real event. However, when winning a game by slaying a dragon, the dragon is not a real dragon but a fictional one. To play a video game is therefore to interact with real rules while imagining a fictional world, and a video game is a set of rules as well as a fictional world. (JUUL, 2011, p.1)

In a way that, in order for the interaction with the rules to be successful, they need to be well-defined, so the player does not feel bothered or constantly struggling with them while playing the game. Because, as in literature, one can construct a totally unreal world, as Umberto Eco (1984) suggests, in which donkeys fly and the princesses are resurrected by a kiss, and still, it is necessary that this world, merely possible and unreal, exists, according to previously defined structures (we must know if in this world a princess can be resurrected only by the kiss of a prince or another being, and if the kiss of a princess turns into a prince only the frogs or other animals). 
Regarding video games, rules vary from establishing the dimension of the game (platform games, for instance, are played in two dimensions, and the player can only move right or left - right is usually preferred by the developers), to the goal of the game (in Sonic the Hedgehog, for instance, there is no doubt that the goal of the game is to collect the biggest number of points in order to pass the levels and unlock bonus levels, and not only to make Sonic walk from one end to another, in the game).

Massively Multiplayer Online Role-Playing Games "run continuously 24 hours a day, 7 days a week, and which are so large, that no one can ever see all the events occurring, nor can the game be restarted and replayed; they can only be experienced once in real time just like historical events, and each player's experiences will be unique" (WOLF, 2008, p.23).

Thus, MMOs present broader objectives and even a multiplicity of possible goals to be chosen by the player, but they still have specific rules. In Lotro, the player is presented to a character creation screen where they can name their future avatar and choose its race (hobbit, elf, dwarf, beorning or man), its physical characteristics (eye and hair colour, the shape of face etc.) and the place of birth.

Along with these options, the user also must choose a class skill for their avatar. The class skills in Lotro are inspired by John Tolkien's characters. Thus, the options for classes and places of birth are linked to the race, as it is described in Tolkien's books. Therefore, an elf cannot be a burglar, playable only with man and hobbits, nor can it be born in Iron Hills or Erebor, both Dwarf homes. Another important rule is related to the names; each character created by 
the player is unique; therefore, cloned names among the players are not possible, neither is the use of names created by Tolkien or names already used by the programmers in the NPCs. The players can create more than five characters for themselves, with names, classes, races etc. all of them different, to their choice.

The goals of the game are wide, and each player ends up finding their own motives to keep on playing. Because it is a Massively Multiplayer Online Role-playing Game, Lotro allows the player to live a life, the one of their characters, and, because of that, it gives the players the chance to perform ordinary tasks, such as buying and decorating a house, having a job (cook, farmer, jeweller etc.), having a family with up to nine generations with the same last name and adopting other players' characters, among other chores. The player travels through Middle-earth and has the opportunity of becoming a recognized hero when helping the Free Peoples in missions and stories that, at multiple points, follow Tolkien's narrative or, at other times, cross that narrative but with additions created by the developers.

There is a significant number of time differences between video games and narratives to consider. The first one is the fact that the narrative has a beginning and an ending, even if the ending is open to interpretation and the beginning may not be the actual start of a storyline, in the case of narratives that start in media res. The narrative starts and ends, even if, for the character, the ending is a metaphor for a new start, as in Michael Laub's Diary Of the Fall, in which the reader, in the end, discovers that a new life presents itself to the narrator with the arrival of a son. 
Considering the temporality that is characteristic to the narrative, Christian Metz argues that it is a "double temporal sequel", because

there is the time of the thing told and the time of the telling (the time of the significate and the time of the signifier). This duality not only renders possible all the temporal distortions that are commonplace in narratives (three years of the hero's life summed up in two sentences of a novel or in a few shots of a "frequentative" montage in film, etc.). More basically, it invites us to consider that one of the functions of narrative is to invent one time scheme in terms of another time scheme. (METZ, 1991, p.18)

In Metz's citation, there is an opposition in the time of the discourse and the time of the story that coexist. In literature, time presents itself, according to Calvino (1990), as a richness which anyone may use with prodigality and indifference: it is not about being the first to reach a predefined limit; on the contrary, timesaving is something good, because the more we save our time, the more time we may lose. The reader does not wish to achieve goals during his reading process, the player does. The player always has somewhere to go, someone to talk to, an enemy to defeat.

Juul points out that, whilst reading a romance, the reader edifies a plot from the discourse exposed to her/him - most of it in a non-chronological order: "part of the traditional novel-format is a narrator recounting previously happened events. So, we get the time of the narrated, the time of the narration and the time of the reading" (JUUL, 1998, digital source).

Anyways, types and styles there may exist for narratives' beginnings and endings, the dynamics are opposed to those of a 
world in which the user herself/himself develops her/his narrative, as narrator and protagonist at the same time, from her/his own choices, while living with other users as a collaborator, as supporting characters. Lately, I have been attempting to formalize the idea that these games are universes widely developed and that they present themselves in many different aspects. In the words of Helena Cole and Mark D. Griffiths, MMORPGs "are fully developed multiplayer universes with an advanced and detailed visual and auditory world in which players create an individualistic character"; thus, they "provide the only setting in which millions of users voluntarily immerse themselves in a graphical virtual environment and interact with each other through avatars on a daily basis" (COLE; GRIFFITHS, 2007, p. 575-576).

This interaction between the users themselves and between the users and the software makes the perception of time more complex in MMORPGs. In the following, I present some time-related peculiarities that can be found specifically on The Lord of the Rings Online in comparison to J. R. R. Tolkien's book.

\section{THE HOURS OF THE DAY AND THE DAYS OF THE YEAR}

Players have their real time - the time that they are living, as people, their daily routine. When interacting with other players as the real person they are - not interpreting the character's role -, they interact with people all around the globe that also have their own real time, that is, their own time zone and their own daily routine. The game also has its own time zone, called game time, and the player can see Anar (the sun) and Isil (the moon) circling around Arda's sky many times while playing. A whole day, according 
to Lotro's game time, lasts 3 hours and 6 minutes of the player's real time, in which 1 hour, 42 minutes and 20 seconds regard to daytime, and 1 hour, 23 minutes and 40 seconds regard to night-time.

Because of the similarity of Isil and Anar's path to the sun and the moon's path, or even because of the omission of information on The Hobbit and on The Lord of The Rings, it is probable that the reader interprets the counting of the hours of a day in Arda as the counting of the hours of a day on Earth. In the narrative, it is through Anar's paths that the Valar counted the days from there until the "Change of the World". In the game, unlike the counting of the hours, the counting of the days is not that clear.

\section{THE COUNTING OF THE DAYS}

Given its peculiarities and different nomenclature, the Middleearth calendars created by Tolkien and presented on the "Appendix $D^{\prime \prime}$ of The Lord of the Rings - which includes the Shire Reckoning, the Calendar of Imladris, and the King's Reckoning (current in Númenor, Arnor and Gondor) - had the same amount of days in a year as the Gregorian calendar. However, each one of them would adjust the spare hours by withdrawing or attaching days in its own way. The Shire Reckoning was the one with more similarities with the Gregorian calendar on the counting of spare hours, with the year containing 365 days, 5 hours, 48 minutes and 46 seconds (TOLKIEN, 2005, digital source).

In Lotro, it is harder to understand what day it is than to understand the hour of the day in which the character is in. An example of the calendar's inaccuracy can be seen in the letters, which is one of the means of communication between players. In a world 
with no e-mails, players must go to mailboxes scattered around the regions to send messages. The mail makes communication easier because it allows the writing of long messages to other players or group of players, the sending of messages to offline players and the attachment of items to the mail. The addressee of the letter, when online, receives it immediately along with a notification on their Alert Panel, but the mailbox indicates that the mail would have been sent over a month earlier - more precisely, one month one week and five days. Therefore, some hours of the player's real-time can be interpreted as several days in the virtual Arda.

Furthermore, if we consider the seasons of the year, which Lotro follows accordingly to the Northern Hemisphere and that are set with the arrival of correspondent festivals in the game, we can conclude, based on the correspondence panel that a year has more than 365 days. That is to say, if every time Spring starts, in the Earth's Northern Hemisphere, the Spring festival starts on Lotro, and if all mail sent in the player's real-time appears in the virtual Arda as if it had been sent a month earlier, one hour of the player's time may be considered as 30 days to their avatar and, therefore, there are more months between the seasons in the online world than on Earth and, consequently, in Tolkien's Arda.

\section{NONCHRONOLOGICAL TEMPORALITY}

Another peculiarity is that, when transiting through the Middle-earth, the player's character "travels through time" several times when encountering Gandalf and his companions. Frodo, for instance, can be seen in Rivendell before the creation of the Fellowship of the Ring; in Lothlórien, after Gandalf's battle with 
Balrog; in East Rohan, before Boromir's death and in other future locations. Every time the player guides their avatar to Rivendell, Frodo and Gandalf will be there waiting to know what the future holds, even if the player had met him recently mourning the death of the wizard in Lothlórien.

The player's character can also be transported to the past or to the present through the memories of the NPCs when they ask you to hear their stories, such as when Bósi tells the player about the death of the last members of Balin's company in the Chamber of Mazarbul, or even being transported to a time different from the game time by entering an instance with a defined time to occur, like Helm's Deep Epic Battles that always happen at night, as in the book:

It was now past midnight. The sky was utterly dark, and the stillness of the heavy air foreboded storm. Suddenly the clouds were seared by a blinding flash. Branched lightning smote down upon the eastward hills. For a staring moment the watchers on the walls saw all the space between them and the Dike lit with white light: it was boiling and crawling with black shapes, some squat and broad, some tall and grim, with high helms and sable shields. Hundreds and hundreds more were pouring over the Dike and through the breach. The dark tide flowed up to the walls from cliff to cliff. Thunder rolled in the valley. Rain came lashing down. Arrows thick as the rain came whistling over the battlements, and fell clinking and glancing on the stones. Some found a mark. The assault on Helm's Deep had begun (...) (TOLKIEN, 2005, digital source)

The aspects mentioned above and so many others regarding time in Lotro end up pointing to one cause: interactivity. Juul goes 
further in the reflexion about the time of the player's present action and how the time of the Interactive Fiction opposes to the narrative:

You can press the control key, a gun will be fired, and this will affect what's happening on the screen. What you see on the screen can't be past or future, but must be present, since we can influence it. So the three times, the time of the narrated, time of the narration and time of the reading implode in a game, and every time you have interactivity. (JUUL, 1998, digital source)

Therefore, it can be said that the temporal distances of the narrative are not present in the video game. Every time the player's avatar is able to influence the environment, it will be in the present, even if just for that moment and if the character already experienced that event in the future. According to Juul (1998), the pair storyline/discourse is meaningless in a computer game since it simply does not have a dualism so active. In an Interactive Fiction, past, present and future occur concomitantly in a constant movement of conversion and diversion.

\section{SOME OTHER CONSIDERATIONS: REMEMBERING A PAST NOT LIVED}

Often the game references Tolkien's narrative, restricting it as a universe by itself and another medium. In 2017, to celebrate the ten years of The Lord of The Rings Online, the developers programmed a series of free-quests with the objective to remember stories, moments and regions of the already remediated map. The player chooses between the sequences Tales, Travels and Trifles ${ }^{1}$ (LOTRO,

1 The player can switch between them whenever he wants, as long as he respects the numerical sequence, that is, after completing quest \# 1 of one of the sequences, he can do the \#1 of the others or choose between one of \#2. The player can only perform \#3 after completing a \#2. 
10th Anniversary Scavenger Hunt quests, (29.9S, 71. 5W)). All three of them are found in parchments hanging on the Party Tree.

The Tales sequence proposes a strong dialogue with John Tolkien's narrative. In it, the players are led to remember the experiences they had in Lotro and also the ones they had as readers. The players will follow through different important moments from different characters narratives, such as Legolas, Pippin and Aragorn. In the first quest, the players are invited to retrace some of Frodo's achievements, such as enjoy a meal in Tom Bombadil's house, or to accomplish things not even the hobbit was able to, like pet farmer Maggot's "ferocious dogs" which had orders to "eat him" at sight (TOLKIEN, 2005). The players are also supposed to "gather remembrances in Bag End for three times" but it is not said what exactly must be "remembered". However, it is important to say that Bag End is not a location where the player can interact. The hole recreated by Lotro presents a fixed structural characteristic in other words, it is a place where the player could not accomplish anything. Therefore, the player's character would have almost no memory of that place. Before entering Bag End to fulfil the quest, the avatar must speak again to Lobelia Sackville-Baggins, who had, so far, ignored the player in all the attempts at interacting with her. However, she, who is permanently in front of the Bag End, will now start to do nothing but complain about how Frodo left the sink filled with dirty dishes when he departed to the East. Once inside the house, the player will find three shiny floating books. When touching them, the avatar places itself in each one of the books for four seconds as if remembering something. 
However, considering the avatar as a character in that world, which life experiences would it have to remember if it had not experienced any events there? In all other quests in this sequence, the player will be invited to make their character remember something which she/he did not experience. I believe that Tales works beyond the universe of the video game, because it, in fact, invites the player/reader to remember ('gather remembrance') and, in this manner, exposes its structure as a medium, acting beyond this structure, acting in the "in-between locus" ${ }^{2}$ of the dialogue with literature.

Thus, the once reader and now player's "backpack" - metaphor created by Umberto Eco in VI Walks in the Fictional Woods is triggered by Lotro's developers from tasks that explore the narratives that were not remediated. These narratives have not been previously presented to the player because they result from stories lived by characters that are not their own, but by supporting characters created by Tolkien.

Nevertheless, in the theoretical perspectives of media and remediation, the fact that the player is not reliving the events that happened to Frodo and to the other characters from the book does not mean that The Lord of The Rings Online fails at the attempt to remediate Arda, the creatures created by Tolkien, not even the habits that involve them. If the time is originated both by the wonderful beings Ainur and Anar, in Lotro, the player is the wonderful being that rules her/his own present time.

2 In naming the "in-between locus" space, I am appropriating the term used in Portugueses by Silviano Santiago in "O entre lugar do discurso latino-americano" to describe what is transgressive, "in-between" and belongs to both (SANTIAGO, 2000, p.9-27). 


\section{REFERENCES}

CALVINO, Italo (2013). Six Memos for the Next Millennium. London: Penguin.

COLE, Helena; GRIFFITHS, Mark D. (2007). "Social Interactions in Massively Multiplayer Online Role-Playing Gamers". Cyberpsychology \& Behavior. New Rochelle: Mary Ann Liebert, Inc., 10, 575-583. In http://online.liebertpub.com/ cpb Access in: 20.Apr.2017.

DEEN, Phillip D. (2011). "Interactivity, inhabitation and pragmatist aesthetics". Game studies journal. Copenhagen: Game Studies Journal, 11. In http:// gamestudies.org/1102/articles/deen Access in: 06.Sep.2016.

ECO, Umberto (1995). Six Walks in the Fictional Woods (The Charles Eliot Norton Lectures). Cambridge: Harvard University Press.

FONSTAD, Karen Wynn (1991). The atlas of Middle-Earth. Boston: Houghton Mifflin. GREGERSEN, Andreas; GRODAL, Torben (2009). "Embodiment and Interface". In: PERRON, Bernard; WOLF, Mark J.P. (Orgs.). The video game reader 2. New York: Routledge, p.65-84.

HAWKING, Stephen (2017). A Brief History of Time. New York: Bantam.

HUTCHEON, Linda (2013). A Theory of Adaptation. London: Routledge.

JUUL, Jesper (1998). "A clash between game and narrative". Digital arts and culture conference. In https://www.jesperjuul.net/text/clash_between_game_and_ narrative.html Access in: 08.Feb.2016.

(2001). "Games telling stories? - A brief note on games and narratives".

Game Studies Journal. Copenhagen: Game Studies Journal, 1. In http://www. gamestudies.org/0101/juul-gts/ Access in: 08.Feb.2018.

METZ, Christian (1991). Film language: a semiotics of the cinema. Chicago: The University of Chicago Press.

SANTIAGO, Silviano (2000). Uma literatura nos trópicos. Rio de Janeiro: Rocco.

STANDING Stone Games (2017). The Lord of The Rings Online. [Lotro.com]. PC. Boston: Standing Stone Games LLC.

TOLKIEN, J. R. R. (2017). The Silmarilion. London: Harper Collins Publishers. (2012). Tree and Leaf: Including "Mythopoeia". London: Harper Collins Publishers. 
(2005). The Lord of The Rings. London: Harper Collins Publishers.

WOLF. Mark J.P. (2008). The video game explosion: a history from Pong to Playstation and beyond. Westport: Greenwood Press. 


\section{ABALOS NO CORPO, A IMINÊNCIA DE UM MONSTRO? O CIBORGUE EM NEUROMANCER, DE WILLIAN GIBSON}

George Lima (UFU)

Recebido em 27 nov 2018. George Lima é Doutorando pelo Programa de PósAprovado em 29 jan 2019. Graduação em Estudos Literários pela UFU. Possui Mestrado em Linguística pela UESB e Graduação em Letras pela UNEB. Atualmente é integrante do Grupo de Estudos sobre Epistemologia, Ética e Linguagem - UNEB e membro do PSINEMA - Corpo, Audiovisualidades e Psicanálise - UESB/USP. Os assuntos de empenho e que constituem suas investigações giram em torno de problematizações que envolvem semiose, discurso, literatura e videogame.

Resumo: No presente artigo investigamos de que modo o corpo das personagens funciona como condição de existência dos espaços que são dados a ver na obra literária Neuromancer, escrita por Willian Gibson. Por outro lado, notamos que o status dos espaços depende do corpo, que, por sua vez, é determinado por esses espaços, os quais fazem com que a esse corpo sejam associadas instâncias que fogem ao que trivialmente chamamos de natural. Nesses "entre lugares" dos espaços, vemos a iminência fantástica do corpo ciborgue, convergindo matéria orgânica com o maquínico, e, dessa forma, configura-se o que parece ser uma espécie de monstruosidade. Para realizarmos essa leitura, utilizamos algumas noções postuladas 
por Michel Foucault (2013b) em torno da literatura enquanto ser de linguagem, e outras postuladas também por Foucault (2001) e por Jacques Derrida (1971) sobre a monstruosidade de acordo com o domínio jurídico-biológico.

Palavras-chave: Ciborgue; Ciberespaço; Corpo; Neuromancer.

Abstract: In this article, we investigate how the body of characters functions as the condition of existence of spaces that are given in the literary work Neuromancer, written by Willian Gibson. On the other hand, we notice that the status of the spaces depends on the body, which, in turn, it is determined by those spaces, which make that body be associated with instances that escape what we trivially call natural. In the "space-in-between" of the spaces, there is a fantastic imminence of the cyborg body, converging with the machinist, and, in this way, what appears to be a kind of monstrosity end up configuring itself. In order to make this reading, we made use of some assumptions postulated by Michel Foucault (2013b) around literature as a being of language, and other assumptions also postulated by Foucault (2001) and Jacques Derrida (1971) in relation to monstrosity according to the legal-biological domain.

Keywords: Cyborg; Cyberspace; Body; Neuromancer.

\section{INTRODUÇÃO}

Não cessam os trabalhos que procuram informar o caráter visionário entre a novela literária Neuromancer, que fora escrita e publicada em 1984 por William Gibson, com o que temos hoje em termos de tecnologia corpo-computacional. Dessa evidência visionária foi possível extrairmos diversas proposições de estudiosos quando colocamos Neuromancer em relação ao desenvolvimento 
tecnológico que aconteceu posterior a sua escritura: 1) a obra enquanto despertadora de interesses no recém-desenvolvimento dos sistemas de interação computacional e na produção do ciberespaço (HAYWARD, 1993); 2) cyberpunk que, como outras do mesmo gênero, apresenta a construção de visões de mundos futuros do ciberespaço com toda uma vasta gama de desenvolvimentos tecnológicos e relações de luta (FEATHERSTONE \& BURROWS, 1995); 3) limiar de existência mais recente do ciborgue que aponta para formas de existência pós-corporais, do corpo orgânico em conexão com o maquínico (SANTAELLA, 2003); 4) obra noir com força do imaginário residente na descrição e sensação narrativa como ferramenta de observação da sociedade contemporânea (AMARAL, 2008); e 5) proveniência de aspectos discursivos que são vividos e materializados hoje em videogames (LIMA, 2017).

De modo sintético, o que podemos dizer a respeito dessas proposições e somar a elas é que, entre a segunda metade do século XIX e o século XXI, presenciamos um grande avanço tecnológico em termos de funcionamento e popularização do ciberespaço, . isto é, cada vez mais os computadores foram se tornando mais complexos e seus abismos de redes de conexão foram sendo povoados aos poucos, fazendo com que muitos dos aspectos materializados em Neuromancer pudessem ser desdobrados hoje por nossos corpos [de fato] como se fôssemos os próprios cowboys (hackers) dados a ver na obra.

Esse visionismo gibsoniano traz à tona no seu modo de inscrição do ciberespaço um germe do que Michel Foucault (2013a) havia pronunciado numa conferência do Círculo de Estudos Arquiteturais em Paris sobre "heterotopologia", duas décadas anteriores à 
publicação de Neuromancer. A novela de Gibson materializa com precisão na sua superfície de inscrição um tipo específico de relação entre espaços bem semelhante ao que Foucault propôs na sua analítica dos espaços durante aquela conferência. Assim, se Gibson proporcionava implicações de algo que viria a ter existência num futuro próximo, Foucault já disponibilizava de pressupostos teóricos e metodológicos para a análise desses espaços outros a que a obra gibsoniana é profética.

Convém referirmos aqui à existência de um ensaio escrito por Wesley Dalton (2014), no qual o autor se propõe fazer uma miseen-scène reflexiva mostrando como a heterotopia teorizada por Foucault (2013a) dá forma à disposição dos espaços materializados em Neuromancer. De outro modo, se não diferente a esse artigo, nosso objetivo aqui é colocarmos em cena o corpo das personagens, visto que parece imprescindível que ele seja fator determinante na constituição desses contra-espaços que o mesmo ocupa. Portanto, é pensando com Foucault que nos debruçamos na análise de Neuromancer, investigando a maneira pela qual os corpos das personagens da obra são determinantes na constituição do ciberespaço.

Por outro lado, vemos que não só o status dos espaços depende do corpo, como também este corpo é determinado por esses espaços, fazendo com que a ele sejam associadas instâncias que fogem do que trivialmente chamamos de natural, tipo de ritual de entrada ou chave de entrada para se estar nesses espaços. Ainda aí veremos aparecer um corpo fantástico em sua iminência, convergindo matéria orgânica com o maquínico e, dessa forma, configura-se o que parece ser uma espécie de 
monstruosidade. Fantástico e monstruoso porque traz para a sua existência e para a sua morfologia a transgressão de leis num domínio jurídico-biológico.

\section{LITERATURA E CONSTITUIÇÃO DOS ESPAÇOS}

O primeiro aspecto da obra gibsoniana a que damos atenção aqui é a singularidade constitutiva dos espaços que aparecem na obra. O fato desses espaços funcionarem como base constitutiva para todos outros aspectos que aparecem e contornam a obra gibsoniana se torna o motivo pelo qual damos essa atenção a priori. A matrix, ou o ciberespaço (ciberspace), mostra-se como ponto central na constituição desses espaços que aparecem na obra, tendo uma construção própria e, pelo que se sabe, sendo pela primeira vez utilizada e empregada de forma definida no curso da história.

De acordo com Mike Featherstone e Roger Burrows (1995, p.5), o termo ciberespaço é genericamente tomado como um conjunto de tecnologias que tem em comum a capacidade de simular ambientes nos quais humanos podem interagir. No entanto, diferentemente desta concepção genericamente utilizada pelos teóricos da comunicação, o ciberespaço em Neuromancer designa um universo de redes digitais, o qual se torna terreno de encontros e aventuras, lugar dos próprios conflitos bélicos e de relações corporativas, não funcionando necessariamente apenas como simulação. A própria obra descreve:

(1) A matrix tem suas raízes em games de fliperama primitivos [...]. Ciberespaço. Uma alucinação consensual vivenciada diariamente por bilhões de operadores autorizados, em todas as nações, 
por crianças que estão aprendendo conceitos matemáticos... uma representação gráfica de dados abstraídos dos bancos de todos os computadores do sistema humano. Uma complexidade impensável. Linhas de luz alinhadas no não espaço da mente, aglomerados e constelações de dados. Como luzes da cidade, se afastando... (GIBSON, 2008, p.77)

Afastando-se da imagem genérica de ciberespaço, a obra gibsoniana constrói a matrix de modo que possamos entendê-la enquanto um espaço que, embora vivido e tocado, é formado por elementos abstratos intácteis. Contudo, embora não conversando entre si em termos de sentido, essas duas construções de ciberespaço têm em comum o uso de um discurso que separa e une, contraditoriamente, em termos foucautianos, o espaço físicoconcreto do espaço intáctil-virtual para criar as bases materiais da matrix de computadores e de videogames/fliperamas.

Observamos que essa separação instaurada por esse discurso se dá no nível da duplicação que caracteriza a própria obra literária, isto é, o discurso vai se materializar no próprio exercício da linguagem literária, que se caracteriza por exercer certa autonomia ao obliterar a referência e a produção de sentido, voltando-se a si mesma numa espécie de autorrepresentação. Isso retoma o que Foucault (2013b) escreveu sobre o caráter ontológico da literatura: a escrita literária significando não a coisa, mas a própria palavra, a literatura se aprofundando na impalpável densidade da sua autorrepresentação para ser o que ela pretende ser. Assim, o uso metodológico das palavras "autorrepresentação", "reduplicação" e "espelho" se torna fundamental para compreendermos de que modo esse discurso vai se constituir no corpo da obra. 
Nesses termos, podemos compreender que há um sistema de reduplicação entre espaços, colocado pela obra gibsoniana a partir do qual o ciberespaço não pode ser compreendido como o espaço físico que caracteriza, por exemplo, a geografia táctilsensorial das ruas, vielas ou jardins que visitamos em nosso dia a dia, mas como um espaço interior de uma projeção virtual de uma tela gráfica na qual podemos, enquanto operadores de avatares, acessar informações virtualizadas que compõem o videogame/ fliperama, a internet ou, de modo geral, a matrix. Esse sistema de reduplicação é apresentado pela própria obra gibsoniana quando vemos a narração espacial dos ambientes que as personagens da obra perpassam.

O que chamamos de narração espacial dos ambientes confere um tipo de paralelismo das descrições dos espaços durante a narrativa que faz com que cada ambiente funcione como uma espécie de espelho que afirma e nega o outro [espaço] - por exemplo, o ambiente urbano em paralelismo com o espaço rural. Vejamos uma formulação de Neuromancer:

(2) Um ano ali e ele ainda sonhava com o ciberespaço, a esperança morrendo um pouco a cada noite. Todo o speed que tomou, todas as voltas que deu e as esquinas de Night City por onde passou, e ainda assim ele via a matrix em seu sono, grades brilhantes de lógica se desdobrando sobre aquele vácuo sem cor... O Sprawl ficava a um longo e estranho caminho de distância sobre o Pacífico, e ele não era mais nenhum cara do console, nenhum cowboy de ciberespaço. Apenas mais um marginal na viração. Mas os sonhos apareciam na noite japonesa como figuras de vudu eletroluminescente, e ele gritava, chorava dormindo, e acordava 
sozinho no escuro, curvado em posição fetal em sua cápsula em algum hotel-caixão, as mãos trincadas no colchonete, a espuma sintética enroscada entre os dedos, tentando alcançar o console que não estava lá. (GIBSON, 2008, p.25)

Na formulação acima, podemos observar que, além de aparecer o nome do ciberespaço, há, durante a narrativa, a descrição dos sonhos que simulam as experiências da personagem ex-hacker, Case, no ciberespaço. Notamos que essa descrição das experiências no ciberespaço está em paralelo às descrições feitas das instâncias tangíveis, isto é, temos "as grades de lógica em vácuo sem cor" e "vudu eletrolumiescente" sendo refletido por "acordar sozinho no escuro", "mãos trincadas no colchonete" e "a espuma sintética enroscada entre os dedos". Esse mesmo modo de paralelismo se repete em outros momentos da obra. Vejamos outra formulação.

(3) E agora ele se lembrava dela assim, seu rosto banhado na incansável luz dos lasers, as feições reduzidas a um código; suas bochechas banhadas em um fogo escarlate ao mesmo tempo que o Castelo do Mago queimava, a testa encharcada de azul quando Munique caiu na Guerra de Tanques, boca tocada com ouro quente enquanto um cursor deslizante tirava fagulhas da parede do desfiladeiro de um arranha-céu. Ele estava com uma tremenda parada naquela noite, levando um tijolo de cetamina de Wage para Yokohama e o dinheiro já no bolso. Saíra na chuva quente que batia no asfalto de Ninsei e saltava vapor, e de algum modo ela se destacara para ele, seu rosto entre as dezenas que estavam de cara para os consoles, perdidos no game que jogavam. (GIBSON, 2008, p.28-29) 
Agora observando esta última formulação, embora não se tratando de uma descrição de um sonho da personagem, vemos a descrição de uma lembrança vivida por Case durante sua caminhada na Ninsei. Apesar de se tratar de outro tipo de experiência, a descrição da lembrança apresenta certa repetição do paralelismo espacial no funcionamento do ciberespaço em relação à descrição do sonho, visto que põe em funcionamento o abstrato-intangível em relação ao concreto.

Ainda observando a formulação (3), notamos mais uma vez o funcionamento que põe paralelamente duas espacialidades na constituição da obra literária: a da experiência físico-concreta em relação à da experiência virtual-abstrata. Nesse segundo excerto, como podemos ver, são descritas as lembranças da experiência durante a imersão da matrix (ciberespaço) de um fliperama. Durante esta descrição, podemos observar que há a reinscrição do modo de paralelismo observado na formulação (2) analisada. Em (2), podemos visualizar as descrições das lembranças que fazem referência à jogada no videogame de modo que todas as coisas referidas sejam reduzidas a códigos e feixes de luzes, coisas um tanto quanto impalpáveis quando observamos seu paralelismo sobre as descrições das experiências fora da lembrança, como a sensação do dinheiro no bolso ou da chuva quente que batia no asfalto da Ninsei, materializando o discurso que coloca avessamente opostos o virtual-cibernético em relação ao físico-palpável.

Em Neuromancer as formulações das descrições físicas funcionam em relação às do virtual-projetado. Nessa medida, o espaço físico está reduplicado em relação ao espaço virtual de modo que se refira a si mesmo. Esta referência a si não quer dizer 
que a obra representa algo que está fora dela ou é produto de algum tipo de inferência, mas que ela é tomada como referente de si mesma na medida em que traz no seu modo de ser o recurso da reduplicação dos espaços descritos para trazer para si os limites espaciais do ciberespaço.

\section{INVÓLUCROS CORPORAIS, CORPOS CIBERNÉTICOS.}

A partir do que analisamos até então, apontamos um segundo aspecto de Neuromancer: as experiências corporais no ciberespaço. Poderíamos dizer aqui que nesta obra literária a experiência na matrix é, antes de qualquer coisa, uma experiência corporal. Esta afirmação nossa se baseia na observação de que as descrições que caracterizam tanto os espaços físicos quanto os virtuais são, antes de tudo, descrições de experiências corporais nesses espaços. Não é por acaso que afirmamos que o que é vivido pelo corpo é o que estabelece ou apaga o limiar entre o espaço físico e o espaço virtual, proporcionados pela matrix dos computadores e/ou dos videogames.

Assim sendo, o corpo funciona de acordo com o tipo de relação que se estabelece entre os espaços que aparecem no interior da obra, isto é, o paralelismo espacial é determinado e determinante para o status do corpo. Em Neuromancer, teremos pelo menos três níveis de constituição corporal a depender do relacionamento que se estabelece com os espaços. Vejamos uma formulação sobre o acesso de Case à matrix:

(4) E fluiu, floresceu para ele, um truque de origami de neon fluido, o desdobrar de sua casa sem distância, seu país, um tabuleiro de xadrez 3D transparente se estendendo até o infinito. $\mathrm{O}$ olho 
interno se abrindo para a pirâmide asteca escarlate de Eastern Seabord Fission Authority queimando para além dos cubos verdes da Mitsubishi Bank of America, e alto e bem ao longe ele viu os braços em espiral de sistemas militares, para sempre além do seu alcance.

$E$, em algum lugar, ele estava rindo, em um loft pintado de branco, dados distantes acariciando o deck, lágrimas de libertação correndo pelo rosto. (GIBSON, 2008, p.78)

Observando a formulação (4), podemos notar mais uma vez a matrix sendo caracterizada pelo aspecto virtual-abstrato na medida em que dá a ver elementos impalpáveis e imprecisos como "origami de neon fluido", "desdobrar de sua casa sem distância", "xadrez 3D transparente se estendendo até o infinito" e "braços em espiral de sistemas militares". Mas, como podemos verificar na formulação (4), além dessa visualização, notamos que todos esses elementos só são possíveis se forem olhados por um olho interno ao corpo. Essa abstração torna o olhar algo impalpável, funcionando semelhante a um fantasma ou a uma alma que habita um espaço que o autoriza a estar.

Essa nossa observação se torna mais operante quando consideramos que essas experiências corporais funcionam frente aos elementos físico-materiais que são acariciados pelos corpos que aparecem na obra. Como podemos ver na formulação (4), há uma indicação indefinida de um lugar (loft) onde o corpo "real" da personagem Case está rindo enquanto toca um deck, um aparelho utilizado para acessar o espaço virtual da matrix. 0 modo pelo qual a formulação (4) referencia as instâncias do domínio físico-material faz com que os corpos sejam caracterizados de acordo com os 
espaços que ocupam: um corpo interior, digamos cibernético, que percebe e ocupa as instâncias impalpáveis e fluídas do ciberespaço e, de outro lado, um corpo exterior que toca e vive as experiências físico-materiais do espaço geográfico, ou, como alguns diriam, do espaço real.

Esse mesmo sistema de papéis dos corpos será materializado de uma outra maneira no interior da obra gibsoniana. É possível ver em Neuromancer a presença também de corpos holográficos ocupando lugares físicos quando visualizados. Esses corpos são similares aos corpos carnais, porém impalpáveis. Vejamos.

(5) O concreto se inclinava em degraus até uma espécie de palco central, um círculo elevado com um ringue reluzente de equipamentos de projeção. Nenhuma luz, a não ser os hologramas que se deslocavam e piscavam sobre o ringue, reproduzindo os movimentos dos dois homens abaixo. [...] Cores refletidas fluíam pelas lentes de Molly enquanto os homens andavam em círculos pelo ringue. Os hologramas eram magnificações à potência de dez; nessa escala, as facas que seguravam tinham pouco menos de um metro de comprimento. (GIBSON, 2008, p.61)

Em Neuromancer, o corpo holográfico é um corpo numérico produzido por algoritmos que o dão potência de tamanho na projeção, usando como base os corpos carnais que são refletidos, ou seja, ser projetado não é a mesma coisa que estar de fato num lugar concreto. Essa diferença é o parâmetro de constituição dos corpos que aparecem na obra. Como podemos visualizar, as projeções figuradas no interior da obra são chamadas de hologramas e também colocadas de modo que as encaramos enquanto luzes. Isso 
significa que o que temos enquanto corpo em termos de holografia são reflexos do que temos enquanto corpo carnal. Pode-se dizer aqui que as representações holográficas dos corpos carnais que foram simulados representam a si mesmas, na medida em que são colocadas em relação aos corpos carnais na obra gibsoniana. Isso quer dizer que os parâmetros de diferenciação e de relação entre os corpos holográficos e carnais são estabelecidos na medida em que vemos operar as marcas sensório-perceptivas do corpo. Esses parâmetros separam e põem em relação ao corpo do/no espaço físico-concreto com o corpo do/no espaço intáctil-virtual.

Descrever essa reduplicação entre os corpos não pretende funcionar como forma de taxionomia dos tipos de corpos que aparecem. Esse parâmetro aponta a dificuldade ou, mais precisamente, a impossibilidade de localizarmos os limiares que separam de fato o corpo virtual, uma vez que são interdependentes. Os corpos aí são o parâmetro de separação e relação, mas eles próprios são também os que dificultam esse limiar. Isso nos leva a apontar uma outra configuração para o corpo presente também na obra. Vejamos mais uma formulação:

(6) Ele colocou a bandana de tecido atoalhado preto na testa, tomando cuidado para não perturbar os dermatrodos Sendai. Ficou olhando para o deck no seu colo, mas não estava vendo de verdade; o que ele via era a vitrine daquela loja na Ninsei, o shuriken de cromo queimando com o neon refletido. (GIBSON, 2008, p.77)

Observando a formulação (6), podemos ver pistas de que o corpo da personagem Case sempre está plugado a um deck por meio de dermatrodos, espécie de condutor plugado ao cérebro, 
sobre a pele, para conexão com o ciberespaço. Ver a vitrine da loja da Ninsei e o shuriken de cromo queimando não se trata de algo que está presentificado no espaço físico da obra, são efeitos virtuais do olhar de Case no ciberespaço. Os dermatrodos são a chave no espaço físico para projeção do corpo no ciberespaço e, neste caso, o corpo de Case está tanto no lugar físico quanto no ciberespaço.

Levando em conta esses aspectos, o que vemos aparecer na obra é a representação da ausência do corpo no ciberespaço. No caso específico da matrix, vemos uma função específica do corpo a partir das ações ocorridas no ciberespaço. As ações do corpo na matrix é o parâmetro de caracterização, de diferenciação, de relação e de instauração do espaço virtual da matrix. Isso quer dizer que o corpo no ciberespaço funciona mais precisamente enquanto um espelho em que a personagem pode vivenciar e ser visto em um lugar onde ela não está, um lugar irreal que se abre virtualmente através da superfície corporal no ciberespaço. Os sujeitos responsáveis pela projeção do corpo estão lá, no lugar onde ele não está. Por essa razão é que vemos na formulação (4) a referência indefinida do corpo físico de Case acariciando um deck, uma vez que ele está num lugar distante e próximo ao mesmo tempo, no qual a personagem não está. Vemos aí a instauração do espelho como marca constitutiva do corpo cibernético e da obra literária como um todo. O entendimento desse espelho fica mais visível ao observarmos Case acessar o corpo de Molly na obra:

(7) Não faço ideia. Apenas sei que estou preparando a Moll para um gato de transmissão, então provavelmente irá acessar o sensório dela. 
- o Finlandês coçou o queixo. - agora você vai descobrir como aquelas calças dela são apertadas, hein? (GIBSON, 2008, p.79)

(8) O salto abrupto para dentro de outra carne. A matrix sumiu, uma onda de som e de cor... ela estava passando por uma rua lotada, passando por barracas vendendo software de desconto, preços escritos a caneta hidrográfica em folhas de plástico, fragmentos de música vindo de infinitos alto-falantes. Cheiro de urina, monômeros livres, perfume, krill frito. Por alguns segundos assustadores, ele lutou sem conseguir evitar o impulso de controlar o corpo dela. Depois, se forçou para assumir o estado de passividade, e tornou-se o passageiro atrás dos olhos dela. (GIBSON, 2008, p.81)

Os limites estabelecidos entre os corpos são perdidos à medida em que os vemos se ocupando mutuamente, como reflexos um do outro. O aparecimento de um corpo plugado mostra que há impossibilidade de separarmos o virtual do físico. Molly é uma espécie de ciborgue, união entre computador e corpo orgânico, que substituiu seus olhos por placas metálicas que aprimoraram sua visão. Como podemos ver nas formulações (7) e (8), Molly é acessada por Case, a partir da qual Case vê Molly, mas também, antes de qualquer coisa, vê-se em Molly. Todas as sensações visuais, olfativas e sonoras vivenciadas pelo corpo de Molly são vivenciadas também por Case. Molly aí funciona como uma espécie de avatar de Case a partir do qual ele vivencia um espaço, ou melhor, um corpo que não é o dele de fato. Molly é a representação de um corpo paradoxalmente ocupado e não ocupado por uma personagem. Ontologicamente é improvável separar o corpo cibernético de sua 
presença material na obra gibsoniana, pois mantém relação com sua exterioridade.

\section{ABALOS NO CORPO, A IMINÊNCIA DE UM MONSTRO?}

A natureza do corpo de Molly coloca em questão outras propriedades que fogem da pretensa naturalidade que constitui o corpo humano. Essas propriedades parecem dotar o corpo dessa personagem de capacidades que vão além do humano. Isso se dá de tal modo que permite por vezes que outros corpos o naveguem, operando como uma espécie de computador. Assim sendo, tornase pertinente compreendermos de que modo a personagem Molly se constitui na obra. Vejamos:

(9) Ela balançou a cabeça em negativa. Ele percebeu que as lentes eram implantadas cirurgicamente, fechando as cavidades de seus olhos. As lentes de prata pareciam brotar da pele branquinha e macia sobre as maçãs do rosto, emolduradas por cabelos pretos cortados de modo selvagem. Os dedos fechados ao redor da pistola de dardos eram compridos, brancos e com unhas pintadas de bardo. As unhas pareciam artificiais. (GIBSON, 2008, p.48)

(10) Ela estendeu as mãos com as palmas viradas para cima, os dedos brancos ligeiramente abertos, e, com um clique ligeiramente audível, dez lâminas de bisturi dupla face de quatro centímetros deslizaram de dentro de suas bainhas embaixo das unhas bordô.

Ela sorriu. As lâminas se recolheram lentamente. (GIBSON, 2008, p.49)

Como descrevemos anteriormente, Molly é uma espécie de ciborgue que implantou lentes metálicas no lugar de seus olhos 
para aprimorar sua visão. Além disso, o corpo dela é constituído por lâminas na cavidade abaixo das unhas, que funcionam como espécie de arma. Natural e sintético, orgânico e inorgânico, essa personagem converge um corpo, que no nosso imaginário é formado de músculo e sangue, com elementos que não fazem parte dessa natureza, conferindo a esse corpo um status a priori paradoxal.

Essa descrição feita em torno da personagem Molly nos lembra da perplexidade, da angústia e do medo de desmembramento do corpo humano, uma vez que parece improvável que lentes possam brotar da pele de alguém ao fechar uma cavidade que deveria ser preenchida por olhos, ou que lâminas de bisturi possam simplesmente sair por entre as unhas e a carne dos dedos. Isto é, a existência de Molly abre uma fenda no imaginário real do corpo humano, pois sujeita o natural do corpo, topia implacável, que é o contrário de uma utopia, este corpo feito de músculos e veias, corpo que está sujeito a feridas e aos desígnios do espaço-tempo.

Ainda hoje, no século XXI, depois de termos alcançado diversos avanços no que diz respeito tanto à inteligência artificial quanto à biotecnologia, um corpo como o de Molly é improvável quando relacionamos a obra com sua exterioridade, e só pode acontecer na arte, lugar do improvável e da transgressão por excelência. Toda essa convergência de elementos sintéticos e não-orgânicos no corpo o torna insólito na medida em que carrega consigo e desperta em quem o lê o inverossímil, o incômodo, o infame, o incongruente, o impossível, o incorrigível, o incrível, o inusitado e o informal.

A princípio, a explicação a que nos amparamos ao observar esse modo corporal é a de que se trata de uma anomalia no sentido de 
que foge à normalidade. E de fato o é, de modo que utilizamos um parâmetro jurídico para avaliar sua composição. Jurídico porque segue uma norma que autoriza ou veta. Claro que isso num sentido lato de jurídico. Esse parâmetro jurídico opera de acordo com o que Foucault (2001) chamou de "monstro humano": é na lei que se pode referenciar o monstro, pois o que o define é a razão dele constituir, na sua existência e em sua morfologia, não só uma violação das leis sociais, como também uma violação das leis da natureza.

Considerando de prontidão os abalos ao corpo conjurados a partir da observação do corpo de Molly, notamos que o caráter convergente e paradoxal desse corpo o coloca frente à lei natural que constitui o corpo humano. Isso acontece na medida em que viola a integridade biológica ao unir atributos artificiais e inorgânicos que não têm nada a ver com o imaginário de corpo humano real.

Por outro lado, se seguirmos a esteira da noção de monstro humano teorizado por Foucault (2001), essa mesma configuração corporal, por não corresponder à lei jurídico-biológico, colocarse-á também fora desse domínio jurídico-biológico, armando uma espécie de arapuca para a lei, pondo-se na exterioridade dela. Ao colocar-se fora desse domínio, veremos que esses abalos causados à noção de corpo não a comprometem inteiramente, constituindo uma espécie natural de contra-natureza. Isso quer dizer que o corpo de Molly pode também fugir dessa configuração monstruosa na medida em que contraditoriamente se coloca fora das leis jurídico-biológicas. Isso nos leva a uma outra explicação para a composição corporal, uma explicação que se aproxima do que Jacques Derrida postulou: 
E digo estas palavras com os olhos dirigidos, é certo, para as operações da procriação; mas também para aqueles que, numa sociedade da qual não me excluo, os desviam perante $o$ ainda inominável que se anuncia e que só pode fazê-lo, como é necessário cada vez que se efetua um nascimento, sob a espécie da não-espécie, sob a forma informe, muda, infante e terrificante da monstruosidade. (1971, p.249)

Quando algo novo surge ou nasce, quando esse algo ainda não teve tempo de ser nomeado, a tendência é de que cause estranheza quanto a sua natureza, fazendo com que o tomemos como uma espécie de monstruosidade terrificante e, assim sendo, tememos qualquer contato direto. Deslocando essa noção para compreendermos o corpo de Molly, vemos que não se torna tão terrificante assim a configuração biosintética do ciborgue frente ao seu status ainda recente e não totalmente compreendido. Ainda mais hoje quando a aparente naturalidade do corpo humano se encontra constantemente questionada pelas diversas vertentes não só das ciências biotecnológicas, mas também das ciências humanas e da linguagem. Nesse sentido, o corpo ciborgue é só mais um em mil e uma possibilidades para a obra literária.

\section{CONSIDERAÇÕES FINAIS}

Observando os espaços que constituem a obra literária, encontramos modos de colocar o corpo no jogo de espelho posto pela própria obra, levando-nos a pensar sobre a natureza corporal, isto é, os modos de viver a partir de um corpo que se tem no momento e no lugar em que possui existência: um corpo fundamental, que é muito mais da ordem do vir a ser da literatura que do natural, 
um corpo insólito que perde a equívoca naturalidade e a evidência aparente quando é colocado em relação à sua exterioridade, um corpo que tem uma materialidade movediça, instável, e que ganha visibilidade quando é colocado no jogo das relações.

Em Neuromancer notamos que o ciberespaço (ou matrix) é produto do modo de ser da literatura que tem como parâmetro a reduplicação que separa e une, ao mesmo tempo, o físico-concreto com o intáctil-virtual. Nesses termos, pode-se compreender que há uma relação de diferenciação entre espaços colocados pela novela gibsoniana a partir da qual o ciberespaço, por assim dizer, não pode ser compreendido como espaço físico ocupado pelo sujeito, mas como espaço interior de uma projeção virtual.

Ainda, vimos que a experiência na matrix é, primeiro, uma experiência corporal. Esta afirmação nossa se baseia na observação de que as descrições que caracterizam tanto os espaços físicos quanto os virtuais são, antes de tudo, descrições de experiências corporais nesses espaços. Essa experiência vivida pelo corpo é o que estabelece ou apaga o limiar entre o espaço físico e o espaço virtual, proporcionados pela matrix na obra.

É a partir do caráter movediço desse "entre espaços" experimentado pelo corpo, que vemos surgir a natureza iminentemente monstruosa da ciborgue Molly, que surge como uma figura híbrida, convergida por instâncias paradoxalmente avessas entre si, as quais se colocam fora da normatividade instaurada pelo domínio jurídico-biológico. Molly aí não é só um monstro, mas a metáfora viva dos abalos vividos pelo corpo no limiar entre o espaço físico-orgânico e o virtual-sintético. 


\section{REFERÊNCIAS}

AMARAL, Adriana (2008). "A potência do imaginário de Neuromancer nas origens da cibercultura". In: GIBSON, William. Neuromancer. 4.ed. São Paulo: Aleph. p.313-316.

DERRIDA, Jacques (1971). "A estrutura, o signo e o jogo no discurso das ciências humanas. In: A escritura e a diferença. São Paulo: Perspectiva. p.229-249.

DALTON, Wesley (2014). "Reflected spaces: heterotopia and creation of space in William Gibson's Neuromancer". In lowa Journal of Cultural Studies, Iowa-USA, 15 (1), 36-55.

FEATHERSTONE, Mike; BURROWS, Roger (1995). "Culture of technological embodiment: an introduction". In: FEATHERSTONE, Mike; BURROWS, Roger (Ed.). Cyberspace Cyberbodies Cyberpunk. London: Sage, 1995. p.1-20.

FOUCAULT, Michel (2013a). O corpo utópico, as heterotopias. Salma Tannus Muchail (Trad.). São Paulo: n-1 Edições.

(2013b). "A linguagem ao infinito". In: MOTTA, Manuel Barros da (Org.).

Estética: literatura e pintura, música e cinema. 3.ed. Rio de Janeiro: Forense Universitária. (Ditos e Escritos, III).

(2001). "Aula de 22 de janeiro de 1975". In Os anormais: curso no Collège de France (1974-1975). Eduardo Brandão (Trad.). São Paulo: Martins Fontes. p.69-100.

GIBSON, William (2008). Neuromancer. Fábio Fernandes (Trad.). 4.ed. São Paulo: Aleph.

HAYWARD, Philip (1993) "Situating Cyberspace: the popularisation of virtual reality". In: HAYWARD, Philip; WOLLEN, Tana (ed.). Future Visions: new technologies of the screen. London: British Film Institute. p.180-204.

LIMA, George (2017). Mapeamento do jogo: política do corpo em jogos da série de games Resident Evil. 2017. 112f. Dissertação (Mestrado em Linguística) Universidade Estadual do Sudoeste da Bahia, Vitória da Conquista.

SANTAELLA, Lucia (2003). Culturas e artes do pós-humano: da cultura das mídias à cibercultura. São Paulo: Paulus. 


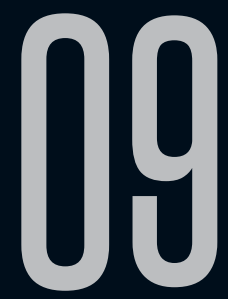

\section{LO MONSTRUOSO NEOFANTÁSTICO DE SACRILEGIO: LA MONSTRUOSIDAD EN LOS UMBRALES}

Nini Johanna Sánchez Ávila (FUAC)

Recebido em 29 dez 2019. Nini Johanna Sánchez Ávila es Candidata a Doctora Aprovado em 28 mar 2019. en Artes, Universidad de Antioquia (Colombia). Profesora de Literatura en la Universidad Distrital Francisco José de Caldas (UDFJC) y la Universidad Autónoma de Colombia (FUAC). Docente de pedagogía de la literatura, teoría literaria, además de literatura y artes en pregrado y maestría. Ha publicado artículos sobre literatura fantástica colombiana como: "Desdoblamiento como eje composicional en los cuentos de Germán Espinosa" (Revista La Palabra) y "Reinterpretación de los sujetos de poder en Los cortejos del diablo: lectura de la modernidad en Colombia" (Revista Pretil). Investigadora de literatura fantástica y la relación entre literatura y artes, perteneciente al grupo LEC (Literatura, Educación y Comunicación) de la UDFJC; ha desarrollado recientemente los proyectos: "Manifestaciones y representaciones del ser: transformaciones, desdoblamientos y rupturas en la obra cuentística de Germán Espinosa" (2016); "Configuración de una teoría articulada de la Literatura Fantástica como contribución a las posibilidades de desarrollo del género" (2017) y "El área de literatura de la Licenciatura en Educación Artística: sistematización de experiencias en torno a los procesos de enseñanza y aprendizaje (2018). 
Resumen: La novela Sacrilegio, escrita en el año 2009, forma parte de la nueva producción de literatura fantástica que se produce en Colombia. Se trata de una narrativa que dialoga con diferentes tradiciones pues recupera elementos del folklore sobrenatural para enlazarlo con nuevas formas de representación en las que prima lo neofantástico y las nuevas monstruosidades. Así mismo, parte de esta nueva narrativa fantástica plantea, también, la negociación entre géneros pues ya no se desarrolla solamente un relato centrado en un tipo de horror o en una sola ruptura de la realidad, sino que busca la confluencia de formas de lo fantástico. Por ello, Sacrilegio vincula la distopía, el horror (tanto psicológico como cósmico) y elementos del folklore sobrenatural propios de la Amazonía Colombiana. El texto busca analizar la novela desde la propuesta de lo neofantástico y las nuevas formas de monstruosidad, para destacar: los procesos de creación de nuevos seres, la diseminación de voces narrativas, la hibridación corporal y espacial, y así observar la confrontación de subjetividades y de identidad. Esta convergencia de visiones sobre lo fantástico requiere un acercamiento a la obra desde autores como Jaime Alazraki (2001) y David Roas (2000 y 2001) quienes plantean nuevas perspectivas del género. Igualmente, se presenta un acercamiento a las nuevas rupturas del sujeto a partir de la construcción de una monstruosidad de umbral, incluso proteica, que dialoga con las nuevas formas de lo fantástico. Para esta última parte se hará relación a las propuestas de David Roas (2013), Hector Santiesteban (2003), Lucian Boia (1995) y William Turner (1988), quienes abordan desde perspectivas diferentes la evolución de la otredad y con ello, la evolución de la monstruosidad. Palabras clave: Monstruosidad; Neofantástico, Umbral; Distopía.

Resumo: O romance Sacrilégio, escrito em 2009, faz parte da nova produção de literatura fantástica produzida na Colômbia. É uma narrativa que dialoga 
com diferentes tradições porque recupera elementos do folclore sobrenatural para ligá-la a novas formas de representação nas quais prevalecem as neofantásticas e novas monstruosidades. Além disso, esta fantástica evidência uma nova negociação narrativa entre gêneros, porque já não se desenvolve apenas uma história centrada em um tipo de horror ou uma única pausa da realidade, mas procura a confluência das formas fantásticas. Portanto, Sacrilegio liga a distopia, o horror (tanto psicológico quanto cósmico) e elementos do folclore sobrenatural típico da Amazônia colombiana. O texto procura analisar 0 romance abordando a proposta do neo-fantasticoé e das novas formas de monstruosidade, para destacar: os processos de criação de novos seres, a disseminação de vozes narrativas, a hibridização corporal e espacial, e assim observar o confronto de subjetividades e identidade. Essa convergência de visões sobre o fantástico requer uma abordagem do trabalho de autores como Jaime Alazraki (2001) e David Roas (2000 e 2001) que levantam novas perspectivas do gênero. Da mesma forma, uma abordagem às novas rupturas do sujeito é apresentada a partir da construção de uma monstruosidade liminar, até mesmo protéica, que dialoga com as novas formas do fantástico. Para esta última parte será sobre as propostas de David Roas (2013), Hector Santiesteban (2003), Lucian Boia (1995) e William Turner (1988), que abordam de diferentes perspectivas a evolução da alteridade e, com ela, a evolução da monstruosidade.

Palavras-chave: Monstruosidade; Neo-fantástico, Limiar; Distopia.

\section{PRESENTACIÓN DE LA OBRA}

Sacrilegio es una novela colombiana escrita en el año 2009 por Simón Jánicas -seudónimo que mantiene al autor en el anonimatoy es editada por Diente de León. Sacrilegio desarrolla un relato que 
oscila entre lo distópico y el horror sobrenatural: se trata de una novela que nos ubica a finales del siglo $X X$ y comienzos del siglo XXI en un momento de cambio histórico que da lugar a una guerra santa que transformará el panorama de la humanidad y generará una nueva historia y una visión distópica del mundo en el año 2335.

\section{SIMÓN JÁNICAs}

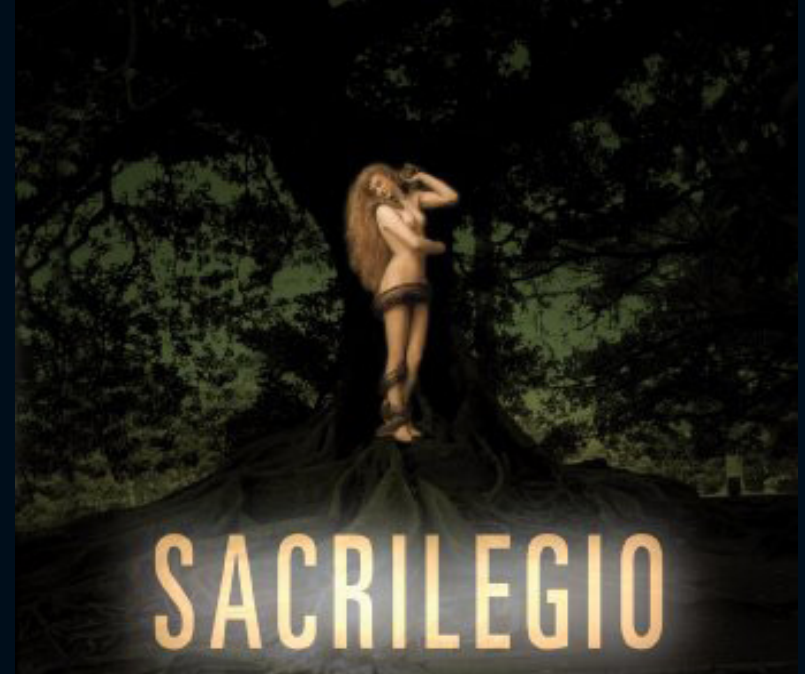

\section{HOVELA}

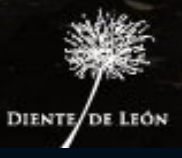

Figura 1: Imagen de sobrecubierta Sacrilegio ${ }^{1}$

1 Imagen de sobrecubierta de la novela Sacrilegio (2009), tomada de la página de la Editorial Diente de León. In https://www.dientedeleon.com.co/titulos-publicados acceso en 1.Dic. 2018. 
El relato gira en torno a los indígenas Iseieke que son descritos como sabios que trascienden el concepto de unidad del sujeto para hacerlo múltiple a través de los siglos y buscan llevar a la raza humana a nuevo orden mundial. En la novela tanto el concepto de sujeto como el de ambiente se transforman constantemente construyendo dobles, avatares y fusiones (se mezclan diferentes naturalezas humanas, animales y vegetales); además, aparece una Cosmópolis monstruosa denominada Ayrebarke, una ciudad abismal donde todos los caminos y los mundos convergen en todos los tiempos y realidades posibles, un espacio de oscuridad profunda que se muestra en tonos de negro y es sólo visible a los iniciados en sus secretos:

Desde el orbe de los sueños, Mi voz le susurraba un cántico sibilino, placentero y desgarrador, desde cuyo sonido comenzaban a brotar las sombras de una imagen infinita. Yo le decía que por uno de los arcanos del Caos ella podría entrar en el Multiverso de los sueños. (JÁNICAS, 2009, p. 15)

Así, la ciudad y la selva convergen como catalizadores de la muerte y la vida que emana la una de la otra. También se reconoce que la ciudad no es un lugar en el sentido convencional, sino que es una experiencia: aparece a partir de un llamado que hace el dios oscuro que la rige y se va materializando de adentro de los sujetos afuera, lo que quiere decir que la ciudad es un espacio interior que aflora como un encantamiento, del poder de la palabra.

Convergen entonces en la novela espacios que se transforman y se rompen: espacios urbanos y selváticos, espacios corporales, además de espacios oníricos que se mezclan. Igualmente, la representación de los sujetos se fragmenta y aparecen imágenes 
de lo humano diferente, de lo monstruoso múltiple; es en esta confluencia de espacios y sujetos que se plantea un análisis para abordar las formas de monstruosidad latentes en el relato y que pueden llevar a reconocer una estética neofantástica.

\section{APROXIMACIÓN A LO NEOFANTÁSTICO Y LAS NUEVAS CARAS DEL MONSTRUO}

La literatura fantástica contemporánea establece lazos con la sensibilidad posmoderna. A partir de este acercamiento aparece la visión de un mundo desestabilizado: sin modelos de realidad o tradiciones de pensamiento que puedan explicar y articular la conciencia humana; sin signos privilegiados con legitimidad definitiva; sin posibilidad de totalizar o de racionalizar la experiencia.

Ante esta acumulación de imposibilidades, autores como Jaime Alazraki y David Roas plantean: "si no sabemos qué cosa es la realidad, ¿cómo podemos plantearnos transgredirla? Más aún, si no hay una visión unívoca de la realidad, todo es posible, con lo cual tampoco hay posibilidad de transgresión." (ROAS, 2000, p.59). Alazraki desarrollaría su concepto de nuevas formas de lo fantástico (neofantástico) planteando que aunque la realidad sea una apariencia o un simulacro, se trata de uno que ha sido aceptado colectivamente como representación de lo posible y de lo normal; así, lo neofantástico aparece como una ruptura de lo normal aceptado, una trasgresión de los estándares de realidad, aunque estos sean inestables, huidizos y se trate de metarrelatos -como organizadores de nuestras visiones de mundo- que van perdiendo vigencia (LYOTARD, 1987). Por ello, Alazraki plantea lo neofantástico desde tres ejes: 
a) "Io neofantástico asume lo real como una máscara" (ALAZRAKI, 2001, p.276) entonces habría una realidad diferente, una realidad otra (o múltiples realidades) que esconde la verdadera naturaleza del mundo.

b) La intención narrativa de lo neofantástico no está en el miedo o en la vacilación clásicas, sino en "metáforas que buscan expresar atisbos, entrevisiones o intersticios de sinrazón que escapan o se resisten al lenguaje de la comunicación, que no caben en las celdillas construidas por la razón" (ALAZRAKI, 2001, p.177), de ahí que se trate de imágenes que tratan de dar acceso a lo indescifrable, materializar lo indecible que no entra en las nociones racionales de la construcción de realidad aceptada.

c) El relato neofantástico abandona la ruptura gradual de lo real, es decir, no presenta lo real para romperlo paulatinamente, sino que desde el comienzo de la narración se presenta la grieta, lo anormal aparece desde el comienzo.

Así, la propuesta de lo neofantástico busca expresar la complejidad de una realidad multidimensional y multitemporal. Deconstruye los metarrelatos de realidad para reconstruir una visión del mundo que permita reconocer el caos en el universo circundante.

De manera complementaria a esta nueva mirada de lo fantástico, David Roas nos da un esbozo de lo que serán las nuevas monstruosidades. En su presentación al número monográfico sobre el Monstruo Posmoderno y nuevas estrategias de la ficción fantástica de la Revista de Estudios Hispánicos Pasavento (2013), Roas ubica al monstruo como parte de la estructura de lo fantástico: 
"el monstruo encarna en sí mismo esa dimensión transgresora: no solo sirve, como decía, para representar (y provocar) nuestros miedos, sino también como vía para problematizar nuestros códigos cognitivos y hermenéuticos." (ROAS, 2013, p.8), de esta manera el monstruo fantástico se convierte es una estrategia para subvertir la noción de realidad y de normalidad.

Entonces, si la concepción de realidad va cambiando y se va haciendo compleja (ya sea que se diluya, se deconstruya o se haga múltiple) la noción del monstruo debe cambiar también en correspondencia. Por lo que pueden producirse dos desarrollos, según Roas:

a) Aparecen obras que "banalizan y/o domestican al monstruo, despojándolo de su excepcionalidad" (ROAS, 2013, p.8), es decir que el monstruo termina siendo incorporado a la estructura de lo real y ya no rompe la norma, por lo que su originalidad, su diferencia se disipa.

b) Aparecen nuevas formas para potenciar sus rasgos esenciales, siendo el determinante la imposibilidad. Además, en esta segunda línea de desarrollo el monstruo tiene otro aspecto destacable: se le da voz directamente, por lo que se hace narrador de su propia historia. Finalmente, esta tendencia puede recurrir a la ironía y a la parodia como elemento que renueva y potencia la monstruosidad.

La novela Sacrilegio juega con este tipo de nuevas representaciones al mostrar varias formas de representación de la realidad que convergen en la historia: una mirada concierne al abismo entre clases sociales, los dominantes políticos y económicos versus 
los dominados; pero también muestra las mismas comunidades marcadas por la ortodoxia religiosa y la heterodoxia; no se centra en una sola comunidad religiosa, sino que plantea a los ortodoxos y heterodoxos de cualquier posible secta y religión. La polaridad, entonces, vista como una abominable monstruosidad del ser, se convierte en el discurso a combatir. Sería esta la indecible naturaleza de lo humano que va aflorando para destruir al mundo, mientras que los tradicionales comportamientos monstruosos adoptan aquí la categoría de deber ser: todos los sujetos deberían abrazar su profunda multiplicidad y en ella convertirse en verdaderamente humanos, en radicalmente diferentes.

\section{¿CÓMO SE PRODUCEN LOS SERES MONSTRUOSOS?}

Para contextualizar la forma en que emergen los monstruos y cómo se llegará a una propuesta de monstruosidad neofantástica, se retoma el trabajo de Lucian Boia (1995) Entre el ángel y la bestia: el mito del hombre diferente desde la antigüedad hasta nuestros días. Para Boia hay una obsesión en todas las culturas, desde la antigüedad, con la diferencia, el misterio de la alteridad radical. Por ello:

Para asir al personaje de mil rostros, a veces incluso sin rostro, estamos obligados a desplazarnos hacia los confines del perímetro humano y más allá, y penetrar en una zona de contornos imprecisos en que se transgreden constantemente las normas generalmente admitidas de la condición humana. (BOIA, 1995, p.12)

El otro, ese ser enigmático, monstruoso y aterrador, permite que el hombre se reinvente asumiendo multiplicidad de caras, 
de vidas y experiencias que normalmente están prohibidas por el status quo. Es un fantasma de lo humano que juega con semejanzas y diferencias para amplificar los rasgos de anormalidad (biológica, psicológica y cultural). De ahí que los hombres diferentes puedan reconocerse ligados a tres dimensiones que organizan sus rasgos monstruosos:

a) La acción sobre el cuerpo. En este nivel los hombres se hacen diferentes debido a la manipulación del cuerpo como frontera que delimita lo normal: aparecen alteraciones de las dimensiones; juegos de deformidad, diseminación, hipertrofia (falta o exceso); e hibridación entre lo humano, lo vegetal, lo animal y metafísico (unión con los dioses, longevidad por espiritualización). También se encuentra el imaginario de la mutación a partir de la ciencia y la tecnología,

b) El espíritu diferente. Esta dimensión refiere a la diferencia que late en lo humano a partir de grados de conciencia e inteligencia, el grado de comprensión que se tenga del mundo - la perspectiva de interpretación que se tenga (racional, religiosa, irracional, onírica). Cada grado de conocimiento se manifiesta en asociación con un grado de corporalidad, es decir, tanto los rasgos que se consideren positivos, como los defectos se materializan en una configuración del cuerpo (síntesis simbólica de la interioridad como la apariencia angelical, la fealdad extrema, la putrefacción o la ceguera).

c) Las costumbres y el comportamiento. Finalmente, este último aspecto plantea que la condición humana se establece a través de la reglamentación social dada en límites, premisos 
y tabúes. Así, los ámbitos más importantes y recurrentes entre culturas estarán asociados a la comida (canibalismo, vegetarianismo, alimento crudo); y a la sexualidad (desnudez, incesto, promiscuidad, homosexualidad). Aunque las normas se extiendan a otros ámbitos del comportamiento.

En este marco, el monstruo neofantástico retoma los niveles de transgresión generales, pero no los repite de manera tradicional, sino que juega a establecer momentos de normalidad en los cuales puede simular, en un plano o en una estructura de realidad, para desmantelarse en otras. De ahí que se constituya como sujeto de alteridad extrema, de movilidad y de ambigüedad.

\section{LA VOZ DISEMINADA DEL MONSTRUO EN SACRILEGIO}

La monstruosidad adopta formas imprevistas en la novela Sacrilegio (2009) empezando por la eliminación del autor que se desdibuja a través de su seudónimo que es casi un heterónimo. Aún no sabemos quién está detrás de Simón Jánicas, pero al consultar sobre el autor aparece una breve biografía en su perfil de Blogger:

Él afirma haber nacido en algún lugar de la Latinoamérica profunda en la segunda mitad del siglo XX. Vivió entre las sombras, las luces, los sonidos y los olores de las selvas y las montañas donde no se conocen las fronteras trazadas por el hombre. Sin embargo, en la actualidad, es un peatón anónimo en las grandes urbes del mundo donde se solaza y sufre con la cultura global. (JÁNICAS, 2009b, p.1)

Habla de sí mismo describiéndose en tercera persona. Los editores mantienen el secreto de su identidad e incluso en la solapa del texto afirman que el texto llega a través de un abogado que 
se presenta como apoderado del escritor y que todo contacto se reduce al anonimato de unas cuantas llamadas y ninguna presencialidad. En el mismo Blog del escritor aparece también una "supuesta" entrevista concedida a un analista literario apellidado Correa-Fajardo (otro personaje ficcional) que es invitado por el autor para hablar de la novela y que éste pueda hacer una reseña del libro y el autor. El relato se convierte en una expansión de la obra que pretende ubicar al analista en una trama conspiratoria en la que incluso aparece uno de los personajes de la historia. Así, el autor queda escondido a través de su avatar y se convierte en una fantasma del autor, un juego de lenguaje.

Ya en el texto de la novela nos encontramos con dos estrategias importantes para determinar las formas narrativas que adopta la monstruosidad: la primera tiene que ver con el narrador que aparece desde el comienzo como un narrador omnisciente que evalúa acciones y personajes conociendo tanto lo que hacen como lo que piensan, sin embargo, casi de inmediato pasa a ser un narrador intradiegético: "Mi voz irrumpió en su conciencia desde la oscuridad infinita" (JÁNICAS, 2009a, p.11); "Mi voz le susurraba" (2009a, p.15); "Destejo Mis nudos para salir y enquistarme poco a poco en el interior de cualquier cuerpo humano" (2009a,p.17); el transcurso de la narración plantea una incesante oscilación entre la voz en primera persona de los personajes, el narrador externo pero omnisciente $y$ este narrador en primera persona que va colonizando el discurso para hacer de todas las historias su única historia. Él es todos, él es cada uno de los personajes (principales y secundarios), como si fuese un registro de su conciencia y de la memoria humana. 
A su vez, los personajes van pasando por distintos momentos de transformación. Se trata de un cambio que va operando de dos maneras: los personajes recuerdan vidas pasadas, experiencias vividas y sus muertes anteriores, pero entienden que su historia es única y continua y que cada vida contribuye a la misión de una deidad aterradora que habita en el centro del mundo, en el centro de la Amazonía, así como en el centro de cada ser humano. Se trata de:

La Tarasca, La Serpiente, El Dragón o La Bestia. Pero la palabra Ofiuco es la que más Me satisface porque designa a quién subyuga la potencia cismática de todas las proliferaciones del gran ofidio subterráneo. En fin, soy un Superorganismo de nudos. (JÁNICAS, 2009 a, p.17 el resaltado es nuestro).

Esta figura de una deidad oscura, multiforme y omnipresente se va a representar con dos serpientes que se autodevoran, imagen que se sugiere en los nombres que recibe. Partiendo de esta representación simbólica se desarrolla todo un esquema de duplicidad que marca, no solo a la deidad amazónica y ancestral, sino a los personajes tocados por su oscuridad. Esta constante transformación de los sujetos se evidencia en el siguiente cuadro: 


\section{TRANSFORMACIÓN Y ASOCIACIÓN DE LOS PERSONAJES (DUPLICIDAD2)}

\begin{tabular}{|c|c|c|c|}
\hline 1999 & $\begin{array}{l}2335 \text { (después } \\
\text { de } 336 \text { años de } \\
\text { guerra santa) }\end{array}$ & Antigua China & Tribu de los Iseieke \\
\hline $\begin{array}{l}\text { Emmanuelle Bazin } \\
\text { (Diseñadora y } \\
\text { modelo francesa) } \\
\text { Conspiradora } \\
\text { y sacerdotisa } \\
\text { vestal (encargada } \\
\text { de esparcir la } \\
\text { oscuridad) }\end{array}$ & $\begin{array}{l}\text { Niño salvaje- } \\
\text { mutante } \\
\text { Astronauta- } \\
\text { cazador }\end{array}$ & $\begin{array}{l}\text { Zan (infiltrado } \\
\text { en la corte de } \\
\text { Chow Sin, papel } \\
\text { de corruptor y } \\
\text { verdugo) }\end{array}$ & $\begin{array}{l}\text { Atemporales } \\
\text { Mutantes }\end{array}$ \\
\hline $\begin{array}{l}\text { José Asunción } \\
\text { Toscano (obispo } \\
\text { católico de } \\
\text { Leticia, Amazonía } \\
\text { Colombiana) } \\
\text { Daniela Sarmiento } \\
\text { (emisaria de los } \\
\text { Iseieke) } \\
\text { Étienne Millet } \\
\text { (fotógrafo y } \\
\text { acompañante de } \\
\text { Emmanuelle) }\end{array}$ & $\begin{array}{l}\text { Heraldo Serpiente } \\
\text { y Heresiarca de la } \\
\text { Amazonía }\end{array}$ & & $\begin{array}{l}\text { Ciudad de } \\
\text { Ayrebarke } \\
\text { Necrópolis } \\
\text { Amazonía } \\
\text { Corazón del mundo } \\
\text { y del sujeto }\end{array}$ \\
\hline $\begin{array}{l}\text { Hermanos Grimm } \\
\text { Richard (Hermano } \\
\text { mayor) - vinculado } \\
\text { con la aristocracia } \\
\text { neoconservadora } \\
\text { en USA } \\
\text { Arnold (Hermano } \\
\text { menor) - liberalismo } \\
\text { político (JFK) - líder } \\
\text { inmolado }\end{array}$ & & $\begin{array}{l}\text { Chow Sin (Tirano) } \\
\text { Opositor y } \\
\text { corrupto } \\
\text { Wen (Principe } \\
\text { justo - budista) } \\
\text { Inmolado }\end{array}$ & $\begin{array}{l}\text { Ofiuco (dios oscuro } \\
\text { y narrador de la } \\
\text { novela) } \\
\text { Asclepio - vencedor } \\
\text { de la muerte } \\
\text { Cronos - devorador }\end{array}$ \\
\hline
\end{tabular}

Tabla 1. Elaboración propia

2 Acá se alude a tres formas de desdoblamiento como rupturas del sujeto en la literatura fantástica: la fusión (unión de dos para conformar un sujeto); la fisión (separación de dos entidades de un sujeto original) y metamorfosis (como transformación que puede ser asociada tanto al cambio corporal reversible, como al no reversible y puede aludir también a la metempsicosis o reencarnación). El tema se desarrolla completamente en el artículo de Nini Johanna Sánchez "Desdoblamiento como eje composicional en los cuentos de Germán Espinosa" que se incluye en las referencias. 
El cuadro describe y vincula la forma en que los personajes se relacionan a través de los tres relatos que se desarrollan en la novela: el primero empieza en 1999, año que marca el descubrimiento de la tribu indígena y en el cual empieza un proceso de despertar de los sujetos para cumplir con la misión revolucionaria y conspiratoria dada por el dios Ofiuco. El segundo momento está en un pasado remoto en el cual se remite a la antigua china (sin referencia exacta de año, ni mención a personajes históricos rastreables), temporalidad que le ayuda a los personajes de 1999 a recordar su antigua misión, siempre presente en todas sus encarnaciones. Cada vez que se ejecuta el plan maestro para desestabilizar el poder hegemónico aparece una triada de personajes que deben cumplir los mismos roles: unos dominar, otros se transforman en mesías del cambio y otros, en el medio, traman una traición que posibilite la transformación social.

La tercera y última temporalidad aludida se da en un futuro remoto en el cual el dogmatismo, el absolutismo ideológico y el capitalismo extremo como única creencia humana han tomado el poder y han devastado a la humanidad-física y espiritualmente-. En el año 2335, las consecuencias de la guerra santa contra los herejes mutantes (aquellos que despertaron con una conciencia nueva de multiplicidad en el año 1999) han provocado que la humanidad esté al borde de la extinción y que los sujetos convivan en dos extremos: gobernantes marcados por una alta tecnificación social y sujetos subyugados que han involucionado hasta hacerse salvajes (tratados como animales, sin capacidad de comunicarse por lenguaje verbal y a merced de la cacería constante de los astronautas cazadores). Los relatos en las tres temporalidades se van intercalando para unirse 
al final del relato en un mismo futuro desolador y apocalíptico, haciendo de la narración una experiencia fragmentada, monstruosa en sí misma. Además, personajes que en la primera temporalidad aparecen como tres personas diferentes (José Asunción Toscano, Daniela Sarmiento y Étienne Millet) se fusionan en el siguiente relato para convertirse en un sujeto que los incorpora (El heraldo serpiente); otros cambian de sujetos femeninos (Emmanuelle Bazin) a sujetos masculinos (Zan) en otras líneas temporales. Pero, al final, todos van a hacer parte tanto del Ofiuco como de la ciudad mítica de Ayrebarke.

El último elemento que mencionaremos sobre la voz del monstruo multiforme está dado por la lengua que habla el pueblo indígena de los Iseieke, tribu que hace parte del cuerpo y el espíritu de la deidad oscura. Su lenguaje está hecho por sonidos ininteligibles que no corresponden a ninguna lengua natural y en la cual solamente se distinguen fonéticamente dos palabras: la del nombre de la tribu y la de la ciudad legendaria de Ayrebarke, siendo la tribu, la ciudad y la deidad una sola creatura viviente y gimiente. En el texto se describe como la lengua original de Babel, imposible de aprender y pronunciar pero que puede ser entendida por cualquier hablante del planeta pues late en lo hondo de todas las conciencias.

\section{HIBRIDACIÓN DEL CUERPO Y EL ESPACIO EN LA MONSTRUOSIDAD}

Como se alcanza a entrever del apartado anterior, Ayrebarke más que una ciudad es un multiverso, una ciudad de ciudades y al tiempo, una necrópolis subterránea. Es un espacio hecho de 
obsidiana con espejos de oscuridad donde todo se ve en tonalidades de penumbra y profundidad. La oscuridad de la ciudad se encuentra en dos elementos: detrás de los ojos de los personajes, escondiendo los ojos oscuros de la deidad y como una laguna de podredumbre donde descansan los cuerpos de los iniciados que se unen a la deidad transformándose: no en otros sino en ellos mismos, en su profundo yo.

La transformación o mutación no consiste en convertirse en algo o alguien diferente de quien era, sino en convertirse en su yo auténtico, en recuperar la memoria de todas sus vidas, sus cuerpos (femeninos y masculinos, adultos e infantiles). Es una materia que permite la transformación, un lodo proteico ${ }^{3}$ que mata al sujeto y lo hace renacer. De esa sustancia está hecha Ayrebarke y cuando se solidifica se crean tanto los contornos de los nuevos cuerpos, como los muros de la ciudad.

De otra parte, el espacio monstruoso se reconstruye en la multiplicidad de temporalidades pero se dirige, indefectiblemente, hacia un futuro distópico y desolador. La novela plantea una visión distópica del mundo en el año 2335, cuando hay una sola autoridad religiosa que rige el mundo desde templos satelitales, el Kuantun Inquisitorial, autoridad que controla las últimas 7 ciudades humanas (New York, Paris, Moscú, Pekín, El Cairo, Bombay y Latinia). La humanidad alcanza una cifra crítica de 111 millones de habitantes unificados por el monoteísmo obligatorio y la pureza genética que buscaba acabar con la población mutante (salvajes

3 Se hace alusión a Proteo, el personaje mítico referido en la Odisea como un dios marino capaz de cambiar de forma y que podía ver el futuro, razón por la cual es perseguido por los marinos con el fin de encontrar el rumbo en medio del caos. Su cualidad de cambiar de forma es permanente y radical, lo hace él mismo y muchos, por lo cual es casi imposible de atrapar o si quiera de asir. 
que nacen fuera de las ciudades, sin dios ni ley, desconectadas de la red satelital).

También se encuentra el Enclave-A, o la reserva forestal original donde habitan y "descubren" a los Iseieke en 1999, se convierte en el último reducto de lo humano sin eugenesia: allí las personas son de todos los colores y se transforman constantemente por la mutación mística que los marca como salvajes: ya no existen sino 7 ciudades puras, pero en el enclave que queda cerca de Latinia, no hay fronteras artificiales, se trata de un punto donde el territorio y las razas se hibridan. Así, territorio y cuerpo se hacen uno solo: espacio de la pluralidad, del mestizaje y de lo salvaje, lo incontrolado.

\section{ETAPAS PARA LA APARICIÓN DEL MONSTRUO. TERATOGÉNESIS:}

De la propuesta narrativa de Sacrilegio emerge, entonces, una nueva visión de lo monstruoso. Dicha propuesta puede describirse como una teratogénesis, es decir, como un proceso en que se construye y transforma al sujeto que se cree (en apariencia) normal y racional para reconocerse luego como un sujeto diferente. Se proponen, así, tres momentos que marcan la construcción de los personajes.

Posesión. En su texto Tratado de monstruos: ontología teratológica (2003), Héctor Santiesteban plantea que uno de los métodos para la creación de seres monstruosos está en la posesión demoniaca. "tal causa cuenta como premisa la facultad de un alma para transmigrar, aunque sea de manera momentánea, en un ser ajeno a ella" (SANTIESTEBAN, 2003, p.71). Cuando el Ofiuco quería despertar al sujeto y desatarlo lo poseía a través de tentáculos de oscuridad que eliminaban los muros de la conciencia 
y las fronteras de la memoria y de la realidad, para permitir que el dios interno de cada hombre y mujer aflorara. Así que estaban poseídos de sí mismos.

Incubación. En la novela se desarrolla un método para el cambio de los humanos a los mutantes a través del Imbunche, referencia a un hombre-semilla que se enterraba en las raíces de árboles sagrados que volvían sus raíces tentáculos y a través de la putrefacción del cuerpo lo transformaban. Pasando de una vida de unidad y vacuidad a una muerte de multiplicidad, una pesadilla de multisensorialidad, para terminar en un renacimiento como ser multitemporal y expandido.

Aparición del mutante. En el tercer momento de la teratogénesis el sujeto monstruoso es visto como un "cismático o apóstata en trance de mutación" (JÁNICAS, 2009b, p.245). Se trata de un sujeto que no está encerrado en una creencia única y es capaz de sobrevivir al encono fundamentalista, una enfermedad de la conciencia que hace metástasis en las grandes urbes. Su cuerpo responde a su maleabilidad de pensamiento cambiando de materialidad (apariencia, sexo, tamaño) constantemente. El dios multiforme serpentea en su piel y le permite ser otro.

Este proceso describe la manera en que la novela va deconstruyendo a los sujetos y los transforma, pero no unifica los resultados de este proceso de cambio, sino que unos se vuelven más humanos y otros menos. Así mismo, las percepciones de unos y otros son contradictorias pues aquellos que se recuperan y enfatizan su plural humanidad son perseguidos (se normalizan hacia adentro y se convierten en anormales para los demás), 
mientras que aquellos que se vuelven unitarios, se engañan sobre su naturaleza pues deciden desconocer la multiplicidad y optan por la monstruosa unidad, se convierten en normales para la comunidad hegemónica pero en anormales hacia sí mismo (ya que reniegan de su naturaleza verdadera).

\section{EL OFIUCO: EL DIOS DE LA HETERODOXIA Y LA MULTIPLICIDAD}

Ofiuco $^{4}$ es el nombre que recibió Asclepio luego de su metamorfosis en constelación. Según Hesíodo, Asclepio fue castigado por Zeus ante el reclamo de Hades pues el conocimiento de sanación adquirido le permitió "curar" la muerte y romper el orden natural. Al morir Asclepio fue transformado en una constelación rodeado de serpientes que remiten a la renovación constante. La novela denomina a la deidad oscura y multiforme como Ofiuco, pero, además, lo relaciona con el mito de Cronos (Saturno) y las saturnales.

Esta segunda representación mítica-simbólica hace referencia al dios heterogéneo como una bestia oscura como representación del tiempo mismo, de su fluir. Un dios de la transformación que devora a sus seguidores y se apodera de sus cuerpos desechando la inhumanidad (unidad y homogenización) para dar rienda suelta a lo profundamente humano (el intersticio entre el dolor y el placer). Esta conjunción de simbologías hace del Ofiuco un dios del umbral. Un ser monstruoso que habita en las fronteras para romperlas: frontera de la ley, de la virtud, de la lengua, de la razón, del amor, del cuerpo y finalmente de la historia y el poder.

4 Al respecto existe un solo trabajo que aborda el análisis literario de la novela y fue desarrollado por Julián David Vásquez en el año 2016 bajo el título de La serpiente como un todo, en la novela Sacrilegio de Simón Jánicas (trabajo de grado). Su orientación concuerda con este análisis por cuanto aborda el entramado simbólico que desarrolla toda la novela, pero no aborda el componente neofantástico de la misma. 


\section{CONFRONTACIÓN DE SUJETOS}

La confrontación de subjetividades se constituye en el eje fundamental de la alteridad y de la construcción de hombres monstruosos. En la novela se develan dos facciones, cada una encarnación de una creencia, así están los absolutos (hombres que optan por entenderse como únicos) y los Iseieke (seres multitemporales y multiformes o mutantes).

Alos absolutos los marca el dogma de la unidad del sujeto: unidad como metarrelato; como apariencia y simulacro. Esta facción de la humanidad desata una divinidad de la homogenización que debe ser asumida por todos a costa de tener como represaría la muerte. La guerra santa que se desata en la novela se denomina la Ordalía de los Absolutos pues se trata de juicios irracionales por tortura (como en la cacería medieval de brujas con los juicios por agua que probaban si el acusado tenía tratos con el demonio sometiéndolo a ahogamiento): linchamientos, arranques de violencia populista y finalmente, expurgación vandálica de toda heterodoxia. De ahí que la marca de los absolutos es su falta de rostro y su anonimato, se convierten en hordas enardecidas en las cuales todos se hacen uno.

En segunda instancia aparece la tribu de los Iseieke como los opositores radicales. Los enemigos de la fe unificada. Seres del umbral y sujetos de múltiples rostros. Sacrílegos que atentan contra la verdad y la luz que en texto es entendida como símbolo del conocimiento dogmático que hace estallar en cenizas a los hombres que rebosan de verdades inamovibles. La luz no ilumina y enriquece, sino que ciega y quema, todo lo destruye. Por eso el dios de la duda es el de la oscuridad. 
A partir de esta confrontación de facciones de lo humano se desarrolla el relato, pero no abandona la multiplicidad por una forma dicotómica de guerra simbólica. Prueba de ello está en la mención de los zombies. En medio del caos que se desata en el año 1999, cuando los Iseieke aparecen para transformar a la humanidad, muchos empiezan el viaje de transformación teratológico, aunque solamente en apariencia. Se trata de sujetos que aparentan cambio, pero en lo profundo son incapaces de transformarse desde adentro pues la transformación implica la muerte de su ser anterior: sus recuerdos, sus valores y finalmente su cuerpo se debería destruir para mutar. Estos seres de apariencias escuchan el mensaje de la deidad oscura pero no lo comprenden, por lo cual la verdad se convierte en ellos en una llama que devora y purga su inmovilidad carbonizándolos desde adentro. Por eso, en el relato se les describe como seres que vagan sin tiempo y que paulatinamente se desmoronan en cenizas hasta desaparecer. Incapaces de adoptar ninguna postura están condenados a la muerte definitiva, al olvido. Estos sujetos corresponden a las mayorías, a las masas indolentes y apáticas (en unos momentos) o a comunidades de empatía fingida y emoción superficial.

Sacrilegio presenta una mirada del otro que construye una crítica del hombre actual. Un hombre engañado por la información, sitiado por su creencia ciega en verdades mediáticas provenientes de los templos televisivos y de las burocracias religiosas. Un hombre que trata de homogenizarse para purgar toda discrepancia y eludir el problema de pensar diferente. Un hombre que deja de ser hombre y se hace monstruoso pues deja de ser cuando deja de pensar por sí mismo y deja de cambiar. Su 
estatismo lo condena a un infierno de soledad repitiendo ecos de lo que otros dicen, pero sin voz propia.

Así, lo que predomina es una monstruosidad en el umbral. Víctor Turner en su texto El proceso ritual. Estructura y antiestructura (1988), interpreta la liminalidad como un elemento esencial de los usos rituales, vinculado a las crisis de la vida social en las comunidades y evidencian los cambios y buscan renovarse socialmente. Turner plantea que "las personæ liminales [gentes del umbral] son necesariamente ambiguas, ya que esta condición y estas personas eluden o escapan del sistema de clasificaciones que normalmente establecen las situaciones y posiciones en el espacio cultural." (1988, p. 102). Con ello, el sentido liminal de la novela se desarrolla como una representación del cambio ideológico, del diálogo de saberes y de la interacción con los hombres diferentes que no son otros distintos, sino que somos todos.

Una declaración sobre los convulsos tiempos actuales en los que la monstruosidad humana aflora desde fachadas insospechadas: hombres que parecen libres, que parecen dialógicos, que responden aparentemente a la llamada de la modernidad y la democracia, pero son consumidos por sus demonios internos y supeditan el mundo a su deseo. La oscuridad que nos habita se muestra como una latencia, un horror soterrado esperando el momento en el ser humano se abandone a la individualidad extrema y deje morir al colectivo.

\section{REFERENCIAS}

ALAZRAKI, Jaime (2001). “¿Qué es lo neofantástico?”. In Teorías de lo fantástico. Madrid, Arco Libros.

BOIA, Lucian (1995). Entre el ángel y la bestia. Barcelona, Editorial Andrés Bello. 
JÁNICAS, Simón (2009 a). Sacrilegio. Bogotá, Diente de León. (2009 b). "Conversación en la Ópera con Simón Jánicas" y "Perfil". In http://simonjanicas-sacrilegio.blogspot.com/ acceso en 1.Ene.2018.

LYOTARD, Jean François (1987). La condición postmoderna. Madrid: Cátedra. ROAS, David (2000). La recepción de la literatura fantástica en la España del siglo XIX. Tesis Doctoral. Barcelona, Universidad Autónoma de Barcelona.

(Ed.) (2001). Teorías de lo fantástico, Madrid: Arco/Libros.

(2013). Presentación. En: Revista de Estudios Hispánicos Pasavento, Monográfico El Monstruo Posmoderno: Nuevas estrategias de la ficción fantástica. 1(1), 7-10. In http://www.pasavento.com/numero_1.html acceso en 1.Ene.2018.

SÁNCHEZ ÁVILA, Nini Johanna (2016). "Desdoblamiento como eje composicional en los cuentos de Germán Espinosa”. In Revista La Palabra, (29), 103-115. https:// doi.org/10.19053/01218530.n29.2016.5704 acceso en 20.Jun.2018.

SANTIESTEBAN OLIVA, Héctor (2003). Tratado de monstruos: ontología teratológica. México D.F., Plaza y Valdés.

TURNER, Victor (1988). El proceso ritual. Estructura y antiestructura. Madrid, Taurus.

VÁSQUEZ, Julián David (2016). La serpiente como un todo, en la novela Sacrilegio de Simón Jánicas. Pereira, Universidad Tecnológica De Pereira. (Monografía) In http:// repositorio.utp.edu.co/dspace/bitstream/handle/11059/7263/809933V393. pdf?sequence=1 acceso en 15.Jun.2018. 


\title{
A CONSTRUÇÃO DO ANTAGONISTA EM OS MAGOS
}

\author{
Fábio Lucas Pierini (UEM) \\ Giuliane Moreira Gonçalves (UEM)
}

Recebido em 13 set 2018. Fábio Lucas Pierini é Doutor em Estudos linguísticos, Aprovado em 10 mar 2019. literários e tradutológicos pela FFLCH-USP com pósdoutorado em Estudos Literários pela Unesp FCL/CAr. Professor na UEM (Maringá-PR), atuando nos cursos de Secretariado Executivo Trilíngue e Letras na área de Língua e Literatura Francesas, leciona e orienta a respeito de narrativa fantástica no Programa de Pós- Graduação em Letras e no Programa de Iniciação Científica. Participa do GT Anpoll Vertentes do Insólito Ficcional e do Grupo CNPq Estudos de literatura e cultura da Belle Époque: LABELLE. Lattes: http://lattes.cnpq. br/6137312261604268 E-mail: fabiopierini@gmail.com

Giuliane Moreira Gonçalves é Mestranda em Letras pela UEM. Bolsista CAPES no programa federal Idiomas sem Fronteiras na UEM (Maringá-PR), atuando em ensino de língua inglesa para fins específicos à comunidade acadêmica. Desenvolve pesquisa na área de narrativa fantástica sob orientação do professor doutor Fábio Lucas Pierini. Lattes: http://lattes.cnpq. br/3483972617874728 E-mail: giumoreira2@gmail.com

Resumo: A construção das personagens e, em especial, a do antagonista é essencial para o desenvolvimento da narrativa. Diante disto, este trabalho analisa a construção das personagens de 
acordo com as visões de Candido (1968), Brait (1985) e Palmer (2004), além das noções de antagonista defendidas por Propp (2001), Campbell (1997) e Prado (1968). Partindo destas teorias analisadas, avalia-se também a construção do antagonista como um agente do mal, como afirma Campbell (1997), e suas características maléficas e monstruosas pelas visões de Jeha (2007), Molino (1980) e Todorov (1981). Partindo das teorias dos autores elencados, analisou-se a trilogia de Grossman intitulada Os Magos, em especial o antagonista do primeiro livro, A Criatura. Concluiu-se que a construção desta personagem obedece à maioria dos princípios de construção do antagonista discutidos pelas teorias mencionadas, com exceção da discorrida por Jeha (2007) que postula que a maldade do antagonista é interior, uma vez que forças exteriores levam o antagonista de Grossman a agir vingativamente, demonstrando como a maldade e as noções de bem e mal não são fixas, mas socialmente instituídas.

Palavras-chave: Literatura fantástica; Personagem; Antagonista; Os Magos; Monstro.

Abstract: A character's construction, and specially the antagonist's, is essential to the development of a narrative. Therefore, this paper aims at analyzing the characters' construction theories according to the studies of Candido (1968), Brait (1985) and Palmer (2004), and also the notions of an antagonist raised by Propp (2001), Campbell (1997) and Prado (1968). From these discussions, the conception of the antagonist as an agent of evil, as stated by Campbell (1997), is considered, as well as its evil and monstrous characteristics pointed out by Jeha (2007), Molino (1980) and Todorov (1981). Based on the theories previously discussed, the trilogy The Magicians, from Grossman is studied, particularly the first book's antagonist, called the Beast. Thus, this papers argues that the construction of this character obeys most 
of the principles discussed by the theorists, except from Jeha's concept, which states that wickedness is an intrinsic characteristic of an antagonist, since exterior forces, in the novel, make the antagonist act vengefully, proving that the notion of wickedness, as well as the notions of good and evil, are not fixed, but can be seen as socially instituted ideas.

Keywords: Fantastic literature; Character; Antagonist; The Magicians; Monster.

\section{INTRODUÇÃO}

A figura da personagem é essencial na ficção. Seja num romance, peça ou conto, ela é o elemento da estrutura da narrativa que desencadeia a ação. Este pensamento também pode ser percebido em Antonio Candido. Ao escrever A personagem do romance (1968), o autor afirma que a personagem e o enredo representam o intuito do romance, pois exprimem a visão de vida e valores expressos nele. Não obstante, Candido aponta os três elementos centrais do romance: enredo, personagem e ideia, e postula que os dois primeiros constituem sua matéria, enquanto o último apresenta seu significado. Logo, a personagem revela sua primazia, já que ela "vive o enrêdo e as idéias, e os torna vivos" (CANDIDO, 1968, p.39, sic).

Diante disso, este trabalho propõe uma análise da figura da personagem de acordo com a visão proposta por Brait (1985), Candido (1968) e Propp (2001). Além disso, as concepções de antagonista expressa por Propp (2001), Campbell (1997) e Prado (1968) serão estudadas, apontando suas características principais e como elas se desenvolvem na trilogia Os Magos, de Lev Grossman, especialmente no primeiro romance, de mesmo título. Para tanto, conceitos como maldade e monstruosidade propostos 
por Jeha (2007) e Molino (1980) são apresentados com o fim de contribuir para a construção da Criatura, o antagonista da obra de Grossman. A partir disso, este estudo questiona, também, a concepção de antagonista como personagem mau, discutindo a origem dessa maldade e como ela é vista ao longo dos romances que constituem a trilogia.

Para expor as ideias acima mencionadas, a seção a seguir tratará da construção da personagem e, posteriormente, do antagonista, na ficção, levando em consideração os conceitos que geralmente acompanham essa personagem - a saber, o de maldade e o de monstruosidade. Em seguida, a personagem A Criatura, de Grossman, será avaliada a partir da atuação como antagonista na narrativa, levantando questionamentos acerca das teorias analisadas. Por fim, propõe-se uma conclusão acerca da definição de maldade aqui estudada e sua relação com o antagonista.

\section{A PERSONAGEM ANTAGONISTA}

Como mencionado anteriormente, a personagem é figura essencial na ficção e está presente na narrativa desde os seus primórdios. Isto é descrito por Beth Brait em seu texto $A$ personagem (1985), no qual a autora traça um panorama histórico da personagem, trazendo diversas visões da atuação dessa figura na narrativa ao longo dos tempos.

Brait, assim como Candido, preocupa-se em diferenciar a personagem da noção de indivíduo e afirma que a personagem é habitante da realidade ficcional, não podendo, assim, habitar no mesmo tempo e espaço que os seres humanos. Ela vincula a personagem e sua função no discurso ao fazer artístico - destacando 
sua transitoriedade e possibilidade de reflexão dos modos de existência e destino desse fazer.

A autora inicia, então, uma retomada histórica da personagem ao tratar de Aristóteles. Ela afirma que o filósofo apontou dois aspectos essenciais: a personagem que atua ou é constituída como reflexo da pessoa humana, e a personagem enquanto elemento unicamente textual, que possui regras particulares que regem sua existência. Ambos os aspectos são coordenados pelo conceito de verossimilhança, e Brait aponta a personagem como ser "composto pelo poeta a partir de uma seleção do que a realidade lhe oferece, cuja natureza e unidade só podem ser conseguidas a partir dos recursos utilizados para a criação" (1985, p.32). Segundo a autora, esta retomada do filósofo está presente na construção de personagens até meados do século XVIII, quando então passa a ser contestada.

Outro pensador que guia a concepção da personagem até meados do século XVIII, segundo a autora, é Horácio. Para Brait, o filósofo latino associa a função de entretenimento da literatura a uma função pedagógica, dando ênfase, assim, ao aspecto moral das personagens. Dessa maneira, a personagem passa a ser um modelo a ser imitado e contribui ativamente para a concepção de personagens a partir de modelos humanos. Esta visão, juntamente com a desenvolvida por Aristóteles, é a que prevalece na Idade Média, de acordo com a autora, e é vinculado principalmente aos ideais cristãos.

É a partir da segunda metade do século XVIII que esta visão é combatida, segundo Brait. A ascensão da burguesia, as revoluções e o surgimento e consolidação do romance culminam na substituição da visão clássica de personagem por uma visão psicologizante 
que - nos termos da autora - "entende personagem como a representação do universo psicológico de seu criador" (1985, p.38). Tal transformação caracteriza um gosto artístico particular que fará com que, especialmente no século XIX, o romance focalize as paixões e sentimentos humanos, sátiras sociais e políticas, resultando no surgimento dos romances psicológico, histórico e de crítica. Logo, segundo a autora, a personagem é vista, então, como uma projeção da maneira de ser do escritor, abandonando, assim, a visão de imitação do mundo dos vivos.

Já no século XX, com o crescimento do cientificismo, "opera-se uma significativa modificação na concepção da escritura narrativa" (p.40). É neste período, segundo a autora, que a teoria objetiva o conhecimento das especificidades e a obra literária começa a ser analisada como um ser de linguagem. Dentre os nomes que se destacam neste período, tanto Brait quanto Candido (1968) mencionam E. M. Forster. Este autor apresenta um estudo dos elementos do texto literário, intriga, história e personagem, e caracteriza as personagens em dois grandes grupos - que são abordados até os dias de hoje nos estudos literários: personagens planas e personagens redondas. Esta abordagem, segundo a autora, considera a obra um sistema no qual é possível analisar a atuação da personagem em relação aos outros elementos da narrativa, excluindo, assim, elementos exteriores à obra, permitindo "um tratamento particularizado dos entes ficcionais como seres de linguagem, e resulta numa classificação considerada profundamente inovadora naquele momento" (BRAIT, 1985, p.41).

Forster (1927) é um dos principais representantes da abordagem estruturalista da literatura e sua visão de estudo dos elementos da 
obra, considerando sua estrutura interna, apenas, será também retomado por Vladmir Propp em Morfologia do conto maravilhoso (2001), no qual o autor explicita "a dimensão da personagem sob o ângulo de sua funcionalidade no sistema verbal compreendido pela narrativa" (BRAIT, 1985. p.45) - texto que será mencionado posteriormente acerca da figura do antagonista.

Brait, entretanto, assim como Candido, após retomar historicamente as diversas visões de personagem, volta-se para uma visão de personagem que leva em consideração o processo criativo e a figura do autor, tanto quanto a estrutura formal da obra e suas características intrínsecas, relacionando, assim, as visões anteriormente veiculadas pelos teóricos da literatura. A autora afirma que o escritor pode basear suas criações em sua vivência real ou imaginária, sonhos ou pesadelos, mas ele recorre aos artifícios do código formal para criá-los. Para ela, "a materialidade desses seres só pode ser atingida através de um jogo de linguagem que torne tangível a sua presença e sensíveis os seus movimentos" (p.53).

Candido, de maneira semelhante, também traça um breve panorama histórico, mas foca na personagem do romance, apontando o processo criativo do autor na construção dessa figura e as diversas teorias que surgiram nos séculos XVIII e XIX para tratar da personagem.

A postura desse autor, assim como a de Brait, é a de conciliar as teorias propostas anteriormente com o intuito de entender a construção e atuação da personagem na ficção. Candido se refere à estrutura novelística para tratar do romance, mostrando que seu foco é este gênero narrativo. 
Candido retoma o conceito aristotélico de verossimilhança e afirma que sua principal expressão é a personagem. Para o autor, esta figura é uma criação que representa uma verdade existencial. Esta verdade é a que estabelecerá a relação com o leitor, fazendo com que este se relacione com a personagem e, assim, considere o romance verossímil.

O autor também aponta a importância dos elementos estruturais do texto ao afirmar que "no fim de contas a construção estrutural é o maior responsável pela força e eficácia de um romance" (CANDIDO, 1968, p.40, sic). Além disso, o autor aborda, também, o trabalho de Forster com a classificação dos personagens, e menciona ainda as categorias estabelecidas por Johnson, no século XVIII: as personagens de costumes e as personagens de natureza.

Candido dedica, também, grande parte de seu texto a descrever o papel do autor na criação do personagem. Para ele, a função principal do romancista - autor - é estabelecer e exemplificar as causas e relações de causa e efeito no texto produzido. Quanto às personagens, elas são abordadas de maneira fragmentária, justamente por retomar a visão também fragmentária que um indivíduo tem de si mesmo. Esta visão da personagem, por sua vez, é criada e racionalmente manipulada pelo autor do texto, transformando-o de maneira que o leitor se identifique com essa personagem. Assim, o personagem é claramente inventado pelo autor, mas "mantém vínculos necessários com uma realidade matriz, seja a realidade individual do romancista, seja a do mundo que o cerca" (p.52).

O autor passa, então, a descrever alguns tipos de processos criativos de personagens, e os organiza em dois grandes grupos: ou 
são uma transposição, procurando referenciais por vezes seguidos completamente ou não; ou são completamente inventados, não partindo de nenhuma referência do autor. É possível, ainda, que o autor combine estes dois grupos, e as medidas por ele utilizadas é o que define cada romancista e, consequentemente, suas personagens.

Todavia, após apontar a grande importância do autor na construção da personagem e da trama narrativa, Candido retoma o discurso que declara o texto como elemento suficiente por si mesmo ao afirmar que "a vida da personagem depende da economia do livro, da sua situação em face dos demais elementos que o constituem: outras personagens, ambiente, duração temporal, ideias" (p.58). Aproximando-se do discurso estruturalista, ele declara que a personagem é uma composição verbal, sujeita à ordem das palavras e seus sistemas de coerência que, juntos, organizam a estrutura novelística, e conclui afirmando que a verossimilhança reside, principalmente, na organização do contexto, que permite a unificação dos elementos fragmentados do romance.

É interessante apontar, ainda, outra visão da formação e função da personagem na narrativa. Alan Palmer, em seu livro Fictional Minds (2004), faz uma análise da personagem em uma narrativa com base no funcionamento mental destas personagens. Associando teorias literárias que focam texto bem como discurso, além de teorias da psicanálise em relação ao comportamento humano, o autor propõe que a "narrativa de ficção é, em essência, a apresentação do funcionamento de mentes fictícias" (p.5 tradução nossa) ${ }^{1}$. Assim como Candido, Palmer afirma que a criação da personagem tem uma relação estreita com o leitor. Entretanto,

1 "narrative fiction is, in essence, the presentation of fictional mental functioning" (p.5). 
diferentemente daquele, este teórico enfatiza a semelhança entre o funcionamento da mente das personagens e de mentes reais, afirmando que é justamente por meio desta semelhança que o leitor é capaz de compreender o romance e relacionar suas experiências de vida com as descritas no livro.

Retomando os conceitos de Vygotsky e Bakhtin, Palmer reafirma a característica social da língua e da mente. Ele afirma que estes teóricos têm uma contribuição substancial na compreensão do desenvolvimento do pensamento, uma vez que a abordagem histórico-cultual se constrói com base na interação social, nas práticas culturais e no compartilhamento dos processos cognitivos, enquanto o conceito de polifonia de Bakhtin não se aplica somente à combinação de diversos discursos, mas também das diversas histórias destas personagens.

Bakhtin concebe a polifonia não apenas como uma combinação dos padrões de discurso característicos de várias personagens na narrativa, mas como a apresentação do confronto ideológico de vários pontos de vista de indivíduos em um grupo social. Ele também vê o narrador como um indivíduo engajado neste confronto, e não à parte dele. (PALMER, 2004, p.154 - tradução nossa) ${ }^{2}$

Um dos principais conceitos na teoria de Palmer é o de narrativas integradas - embedded narratives -, o qual tem como um de seus pilares a polifonia de Bakhtin. Para o autor, o fato de a narrativa em primeira pessoa não ser confiável reafirma uma noção de conhecimento

2 "Bakhtin conceives of polyphony not simply as a combination of the characteristic speech patterns of the various characters in the storyworld, but as the presentation of the ideological struggle between the various world viewpoints of individuals within a social group. He also sees the narrator as engaged in this struggle and not aloof from it” (p.154). 
geral: o relato e previsão de comportamento futuro feito por um observador a respeito das ações de um indivíduo geralmente são mais convincentes e certeiros do que o relato do próprio indivíduo. É neste ponto que Palmer relaciona o conceito de polifonia e de narrativas integradas: para ele, ambos situam a consciência de um indivíduo em seu contexto social a partir de um mecanismo que analisa a mente de uma personagem não apenas com base em seu discurso, mas também através dos discursos de outros, ressaltando essa característica do romance de apresentar as narrativas integradas de suas personagens, suas consciências dialógicas.

Para Palmer, o conceito de narrativas integradas dá vazão, também, para a noção de identidade localizada - situated identity -, segundo a qual a identidade de um indivíduo é construída com base na opinião de outros sobre ele. O autor afirma:

Nós relutamos em aceitar as afirmações de alguém sobre si mesmo, e isto me parece uma afirmação subentendida de que nossa mente está distribuída entre aqueles que têm uma imagem de nós em suas mentes. De que outra forma nós afirmamos que alguém é egoísta quando não há nenhuma representação de egoísmo em sua mente? Esta imagem está na mente dos outros, mas nós a atribuímos a uma mente em específico. O conceito de identidade localizada claramente se relaciona, também, com a questão da ação. De certa forma nós não somos exatamente o que falamos que somos, mas somos o que fazemos. A ação é pública e, portanto, confiável - ainda que não infalível -, uma base pela qual outros podem julgar o funcionamento de nossas mentes. (p.168169 - tradução nossa) $)^{3}$

3 “We are all reluctant to take somebody's word for the workings of their own mind, and this seems to me to be a tacit admission that there is a strong sense in which our mind is 
Logo, para o autor, a mente de uma personagem - bem como a de um indivíduo - é construída de acordo com o que os outros pensam dela, de suas ações. Por este viés, o leitor pressupõe que a mente da personagem de ficção funcionará de maneira semelhante à sua. Assim, ele é capaz de criar uma consciência para uma personagem com base nas informações fragmentárias do pensamento desta, que é dada pelo narrador ou por meio do discurso ou pensamento de outras personagens. Desta maneira, a narrativa se constrói com base na apresentação destas informações a na atuação ativa do leitor em organizá-las a fim de criar uma mente fictícia e prever seus pensamentos e atitudes, quando estes não são expostos pelo narrador.

Assim, é possível afirmar que, para Palmer, de acordo com as noções de narrativas integradas e identidade localizada, uma narrativa é a representação do funcionamento mental de personagens, uma vez que elas enfatizam o aspecto público e social do pensamento; sua capacidade de processamento de informações e adaptação diante de situações inesperadas; a relação entre ação e pensamento, que é muito presente na narrativa não só por meio do fluxo de consciência, mas também pela ação do narrador; e o fato de que a narrativa tem vários pontos de vista, que são representados pela relação intrínseca das várias mentes das personagens, que colaboram na compreensão

distributed among those other people who have an image of us in their minds. How else can we say that someone is selfish when there is no representation of selfishness in their mind? This image is in the minds of others, but we are attributing it to this particular mind. Surely then, our identity is distributed among the minds of others. The concept of situated identity is also clearly related to the question of action. In a sense we are not so much what we say we are, but what we do. Action is public and so is a fairly reliable, though not infallible, basis on which other individuals can judge the workings of our minds". (p.168-169) 
do leitor do enredo do romance e possibilitam sua participação ativa na construção deste.

É importante ressaltar que estes são apenas dois dos conceitos apresentados por Palmer em seu estudo das personagens com base em sua ação cognitiva. Entretanto, estas noções representam claramente a visão positiva do autor em relação à figura do narrador e do leitor na construção da narrativa. Contrário às opiniões até então apresentadas aqui, Palmer dá participação ativa ao narrador na história, considerando sua ação necessária e complementar à ação do leitor, a fim de construir as relações e conflitos apresentados pela narrativa - que, por sua vez, representa o funcionamento cognitivo das personagens. $\mathrm{O}$ autor afirma que a abordagem das narrativas integradas é valiosa porque evita as fragmentações das teorias até então apresentadas, vê as mentes fictícias não como representações passivas do discurso, mas através do papel positivo do narrador em "representar o funcionamento social da mente [...] e destaca o papel do leitor, o processo pelo qual o leitor constrói o enredo por meio de uma série de conjecturas e hipóteses provisórias sobre as narrativas integradas dos personagens" (p.185) ${ }^{4}$.

Assim, após uma breve perspectiva histórica da ação da personagem na ficção e o processo de sua criação, é possível, então, apresentar algumas concepções generalizadas da função do antagonista. É importante ressaltar que o presente estudo não pretende aprofundar nenhuma das concepções de personagem acima expostas, mas objetiva mencioná-las a fim de utilizar-se

4 "presenting characters' social mental functioning, particularly in the mode of thought report [...] and it highlights the role of the reader, the process by which the reader constructs the plot by means of a series of provisional conjectures and hypotheses about the embedded narratives of characters" (p.185). 
das visões que melhor expliquem a personagem de ficção a ser analisada posteriormente: A Criatura, antagonista do romance Os Magos, de Lev Grossman (2011).

\section{O ANTAgONISTA}

Para descrever o antagonista, uma definição bastante clara de sua função é dada por Brait (1985). A autora afirma que ele "é o opositor, o protagonista às avessas" (p.88). A partir desta afirmação, é possível compreender que essa personagem exerce uma função essencial na organização do romance. Por se tratar de um opositor, o antagonista é a figura que gerará o conflito do enredo, o ser - ou seres, como afirma a própria autora - que anulará a situação inicial positiva do protagonista.

Esta visão também é compartilhada por Vladimir Propp (2001). Em Morfologia do conto maravilhoso, Propp trata de um gênero específico, e seu corpus é composto por contos russos do século XVIII. Entretanto, as funções apresentadas pelo autor acerca das personagens são aplicáveis a outros gêneros narrativos de outros períodos históricos, uma vez que, em sua maioria, obedecem à estrutura geral da narração.

Para Propp (2001), o antagonista é um agressor. Sua função é destruir a paz da família feliz, provocando algum dano ou prejuízo. Ele pode ser caracterizado de diversas formas, mas seu papel é sempre fixo. Dentre as funções trazidas por Propp acerca dessa personagem, podemos destacar: VI. O Antagonista Tenta Ludibriar sua Vítima para Apoderar-se dela ou de seus Bens, VIII. O Antagonista Causa Dano ou Prejuízo a um dos Membros da Família, entre outros. 
Outro aspecto interessante trazido por Propp e que também se assemelha ao que foi proposto por Brait (1985) é o fato de que, para o autor, a relação entre o protagonista e o antagonista é constituída sobre a oposição próprio/alheio, a qual pode se projetar em diversos planos. Tal ideia se relaciona com a noção de "às avessas", de Brait. Logo, pressupõe-se que as atitudes e pensamentos tomados pelo protagonista serão o inverso das tomadas pelo antagonista.

Assim, identificado o protagonista, seu inimigo é facilmente apontado pela estrutura narrativa, preparando o leitor para suas ações repressoras e prejudiciais em relação ao antagonista. Isto também é apontado por Décio de Almeida Prado (1968), em A personagem no teatro, quando o autor afirma que o antagonista é uma personagem de contraste e, como tal, atua em função de ressaltar a personagem principal, dando-lhe relevo por meio do jogo de luz e sombra. Portanto, conclui-se que a função desta personagem na narrativa é a de contrapor-se ao protagonista, gerando um conflito que será resolvido por este, culminando na realização de seus desejos e na derrota de seu rival.

Definida a função do antagonista na trama narrativa, reside, ainda, a questão relacionada à sua motivação. Campbell (1997) resolve o problema de maneira simplificada ao afirmar que o antagonista é "o representante do mal" (p.156). Tal afirmação apresenta a intenção do antagonista - fazer o mal a seu rival -, mas traz a tona, também, uma questão até então não cogitada: a maldade.

Acerca do conceito de maldade, Julio Jeha (2007) afirma, em seu texto Monstros como metáforas do mal, que o mal é qualquer obstáculo que impede um indivíduo de alcançar seus objetivos, 
necessidades e, principalmente, de alcançar a perfeição. Ele é o oposto do bem e por isso deve ser combatido. $\mathrm{O}$ autor afirma, inclusive, que a ação maldosa deve ser atitude consciente de seu agente, caso contrário seria apenas um acidente. Isto se relaciona com o que foi afirmado por Campbell (1997) acerca do antagonista já que, uma vez sendo o representante do mal, esta personagem age conscientemente a fim de causar prejuízo ao seu oponente.

Jeha aponta, então, duas vertentes do mal: o mal moral e o mal físico, e afirma:

o mal moral [...] consiste na desordem da vontade humana. Vícios, pecados e crimes são exemplos de mal moral. Enquanto o mal físico é sempre sofrido, quer ele afete nossa mente ou nosso corpo, o mal moral surge quando, livre e conscientemente, infligimos sofrimento nos outros. Para que esse tipo de mal possa ocorrer, o agente tem de se decidir a abandonar sua integridade moral,; assim, ele afeta tanto a vítima quanto o agente. $(2007$, p.16)

Assim, percebe-se que a maldade é uma escolha do agente que não só afeta sua vítima, mas também a si próprio, já que esse decide abandonar sua integridade moral para cometer seus atos de maldade. Logo, para o autor, o mal é predicado da existência humana, característica inerente dos agentes morais.

O autor aborda, então, a maldade na literatura. Para ele, quando falamos de mal, tendemos a criar referências metafóricas e, no meio estético, isto se dá através da monstruosidade (ou monstro). Jeha comenta brevemente, então, como a figura do monstro foi vista ao longo dos tempos e afirma que para os gregos e romanos da antiguidade, o monstro era uma figura que representava um aviso 
contra a desobediência aos deuses, mas também era comumente visto como um prodígio. Essa visão prevalece até meados do século XII, e o termo "monstro" era usado para caracterizar uma criatura meio humana, meio animal, fruto de uma ação sobrenatural, e que poderia ser compreendido como prodígio e maravilha.

Já no século XIII, o monstro não é uma maravilha, mas é um indivíduo com deformidade, e sua característica positiva se desfaz. Esta mudança exprime uma retomada aos princípios aristotélicos da arte, uma vez que, para Aristóteles, a arte consistia na representação do belo, e este "reside na extensão e na ordem" (ARISTÓTELES, 2005, p.27). Não obstante, o teórico afirma que o herói de uma tragédia é virtuoso, justo, afasta-se do vício e da maldade, desfrutando de prestígio e prosperidade. Tais características referidas ao herói, bem como a presença direta da ordem, impedem uma narrativa na qual um monstro seja visto de maneira positiva. Desta maneira, o caráter disforme do monstro ganha destaque e, como afirmou Prado, traz relevo ao herói, destacando-o por suas qualidades positivas.

A visão proposta por Jeha para a figura do monstro na literatura é política. Para ele, o monstro é o mantenedor das regras sociais, "é um estratagema para rotular tudo que infringe esses limites culturais" (p.20). O autor afirma que essa figura atua como um aviso ou castigo por uma atitude que desrespeita um código social ou um mal cometido, mostrando ao leitor a atitude correta a se tomar para não cair na mesma desgraça, oferecendo, assim, uma separação categórica de bem e mal e uma visão de mundo compartilhada por um grupo. 
Dentro das teorias de literatura fantástica, encontramos, também, alguns estudos acerca da figura do monstro. Um dos teóricos a discutir este tema foi Jean Molino (1980). Em seu texto O fantástico entre o oral e o escrito, o autor propõe um estudo do fantástico a partir do folclore e dos gêneros orais e, dessa forma, aborda a figura do monstro.

Ele afirma que, até o século XIX, o monstro era um tema bastante recorrente no fantástico, e era geralmente associado à figura do diabo. Molino, assim como Jeha, afirma que o monstro era - e ainda é, no fantástico, apesar de sua construção atual ser apenas um eco do que ele significava anteriormente - resultado de uma infração à regra estipulada, uma perversão das criaturas. Ele é, também, resultado de uma ação do diabo, que ambiciona a destruição da ordem do mundo por meio de metamorfoses. Aqui, o autor aponta a transfiguração física como marca da monstruosidade e afirma que "sua simples presença, que faz ver a ruptura ruim das leis e das regras, é o suficiente para criar o fantástico sob sua forma mais pura" (p.55).

Por fim, é possível ainda relacionar à figura do monstro a outro autor da teoria fantástica. Tzvetan Todorov (1981), em seu texto Introdução à literatura fantástica, trata da constituição do fantástico enquanto gênero literário e propõe dois grupos temáticos ao gênero: os temas do eu e os temas do tu. Em relação a eles, o autor afirma que os temas do eu apontam para uma ruptura entre o psíquico e o físico, enquanto os temas do tu apontam para a relação do homem com seus desejos - seu inconsciente.

Ao tratar dos temas do tu, Todorov aborda, assim como Molino, a metamorfose. Para ele, a metamorfose representa "uma 5 Tradução de Ana Luiza Camarani. 
transgressão da separação entre matéria e espírito" (p.60). Ela é física, ou seja, é a passagem da personagem do estado natural ao sobrenatural. Este tema relaciona-se ao tema também proposto pelo autor como um tema do tu, que é o pandeterminismo. Ambos evidenciam a ruptura entre matéria e espírito, mas o pandeterminismo tem como objetivo evidenciar a ação do sobrenatural sobre a narrativa, pois determina que todo ato gera um efeito e tem origem no sobrenatural - quando não explicado pelas leis naturais. Assim, o pandeterminismo propõe uma explicação à metamorfose: ela acontece de forma sobrenatural e como punição pela ruptura dos padrões estabelecidos entre matéria e espírito, e, com isso, gera o fantástico na literatura. Ou seja, o monstro, fruto da ação sobrenatural de metamorfose, é um dos caminhos que a literatura fantástica opta por seguir.

Concluída esta breve análise acerca da figura da personagem e do antagonista, bem como os conceitos de maldade e monstruosidade que acompanham a noção de antagonista -, a seção a seguir evidencia como estes conceitos e elementos da narrativa se manifestam na trilogia Os Magos, de Lev Grossman, em especial o antagonista do primeiro romance, que dá nome à trilogia.

\section{A CRIATURA DE GROSSMAN}

Os Magos (2011), O Rei Mago, (2012) e The Magicians Land $(2014)^{6}$ são os títulos de Lev Grossman que compõem a trilogia que leva o nome do primeiro romance. O protagonista desta história é Quentin Coldwater, um jovem de 17 anos que descobre, acidentalmente, não só a existência da magia, como também uma 
instituição de ensino superior que, após extensa avaliação, o recebe como estudante de magia.

No primeiro romance, ao longo de suas aventuras, Quentin faz amigos magos - humanos e não humanos - e descobre a existência de outros mundos além da Terra. Dentre esses mundos está Fillory, um mundo mágico que era até então ficcional na vida do protagonista - Quentin, desde menino, era fã de uma série de livros intitulada Fillory e além, na qual cinco irmãos visitam este mundo mágico e vivem diversas aventuras. Maravilhado com a realização de seus sonhos mais ocultos, e em meio a diversas complicações em suas relações com outras personagens, o protagonista chega a Fillory com o intuito de participar de alguma aventura e, por fim, tornar-se rei.

A aventura, é claro, é impedida pelo antagonista, intitulado A Criatura, que, quando desmascarado, revela ser, na verdade, um dos cinco irmãos da série ficcional Fillory e além: Martin Chatwin, o irmão mais velho. Após confronto, A Criatura é vencida, mas a vitória de Quentin é manchada pela morte de sua namorada, Alice Quinn, a qual abre mão de sua vida ao utilizar a magia além do permitido - e metamorfosear-se em um ser puramente mágico, um nifo ${ }^{7}$ - para salvar o protagonista.

A primeira aparição do antagonista em Os Magos é durante uma aula na universidade de magia de Brakebills. A Criatura aparece quando Quentin, entediado com a aula, faz um encantamento para atrapalhar o feitiço que um dos professores está ensinando aos alunos e, por meio dessa fissura, A Criatura surge na sala de 
aula. Todos ficam completamente paralisados, e ninguém parece capaz de reagir à ameaça que surgiu diante eles. Sua descrição é bastante característica:

Era um homem baixinho de trajes conservadores, um belo terno cinza britânico e uma gravata marrom pregada no lugar com um broche de prata na forma de uma lua crescente. O professor March, que ainda estava falando, pareceu nem se dar conta de que ele estava ali - o homem olhou para os terceiro anistas com um ar malicioso e conspiratório, como se estivesse fazendo uma piada à custa do professor. Havia algo de estranho na aparência daquele sujeito - Quentin não conseguia ver direito o rosto dele. Por um instante, ele não entendeu muito bem por que, mas depois percebeu que era por causa de um pequeno galho cheio de folhas que ele tinha sobre o rosto, cobrindo parte de suas feições. O galho saía do meio do nada e não estava preso em lugar algum. Ele simplesmente estava lá, pendurado na frente do rosto daquele homem. (p.131)

A Criatura passa, então, a perambular pela sala de aula, mexer nos equipamentos, como se esperasse algo. Em certo momento, ele lança uma magia que o protagonista não consegue compreender e, após cantarolar, simplesmente desaparece. Após este incidente, Quentin descobre que A Criatura havia, com o feitiço lançado, matado uma de suas colegas de sala, que tentou lutar contra o antagonista. Ele descobre, também, neste momento, a existência de outros seres, além dos humanos, e de outros mundos.

O protagonista só volta a encontrar seu opositor ao final do livro, quando, desobedecendo a ordem expressa de um dos deuses de Fillory, ele usa um artefato mágico em busca de ajuda e, na verdade, 
invoca A Criatura. Ao ter sua identidade revelada, o antagonista é descrito como um monstro e sua relação com o protagonista é estreitada: "Tudo estava ficando claro. Martin Chatwin não havia sido raptado por monstros, mas sim se transformado em um. Ele havia conseguido achar o que Quentin tanto queria, uma forma de ficar em Fillory para sempre. No entanto, isso teve um alto preço." (GROSSMAN, 2011, p.401).

Esta passagem é essencial para que algumas relações sejam estabelecidas. A primeira delas é a questão do monstro. Como discutido anteriormente, o antagonista é o representante do mal (CAMPBELL, 1997), e sua maldade pode se manifestar na literatura na forma de um monstro (JEHA, 2007). Este monstro, como Molino (1980) e Todorov (1981) apontam, pode ser apresentado por meio de uma metamorfose. No caso da Criatura, ele é descrito pelo narrador como um sujeito com feições e estatura infantis, apesar de agir e falar como um homem adulto. Além disso, ele tem 6 dedos em cada mão e carrega um galho no rosto - que só é removido quando sua identidade é revelada, mas inicialmente dá a impressão de que é parte de sua fisiologia.

Assim, a descrição física da personagem aponta para a metamorfose. Este processo éevidenciado poruma escolha estilística de Grossman. Ao longo do romance, pela focalização de Quentin, o leitor toma conhecimento de algumas das aventuras dos irmãos Chatwin, os cinco que se aventuram por Fillory nos livros ficcionais Fillory e além. É interessante ressaltar a importância dada pelo narrador aos fatos relacionados a esta série ficcional. Em diversos momentos o protagonista é relatado como relendo as histórias ou discutindo com seus amigos a respeito da veracidade de alguns 
fatos, como a real existência dos cinco irmãos e o desaparecimento do mais velho, Martin - que será revelado posteriormente como A Criatura. Isto reafirma o processo de metamorfose, pois Martin é mostrado antes, como a criança protagonista da série preferida de Quentin, e depois como A Criatura, completamente transfigurado física e mentalmente.

Outra relação estabelecida a partir da passagem exposta acima é a relação do protagonista com o antagonista. Retomando o que foi proposto por Propp (2001) e Brait (1985), o antagonista é o opositor, o protagonista às avessas. A relação entre eles se estabelece em um jogo de oposições que se desdobra na relação, nas palavras de Propp (2001), entre próprio e alheio. Esta relação é estabelecida quando o narrador afirma que "Ele havia conseguido achar o que Quentin tanto queria, uma forma de ficar em Fillory para sempre. No entanto, isso teve um alto preço" (GROSSMAN, 2011, p.401).

Neste trecho, a oposição entre Quentin e Martin é clara. Ambos desejavam permanecer no mundo mágico de Fillory - o que era estritamente proibido pelos deuses daquele mundo -, mas apenas Martin tomou a atitude de transgredir a regra imposta. A oposição, aqui, é de escolhas: o antagonista escolhe desobedecer, enquanto o protagonista opta por obedecer às regras. É a escolha feita que metamorfoseia Martin no monstro A Criatura, como uma punição à transgressão, como afirma Jeha e Molino.

Diante do exposto, é possível afirmar que a maldade é, assim, como propôs Jeha, inerente ao antagonista, pois sua intenção é, de fato, transgredir a ordem imposta e fazer o mal. Martin apresenta este exemplo quando o narrador descreve o prazer com que ele 
ataca seus opositores, tanto ao matar a colega de sala de Quentin, como ao devorar as mãos de um de seus amigos na luta final.

Fica também evidente, a partir da discussão, como a maldade causa dano não só ao protagonista, mas também a quem a pratica - neste caso, Martin Chatwin/A Criatura. Martin afirma:

Vocês nem imaginam as coisas que se tem de fazer para usar esse tipo de magia... Bom, digamos que o seu lado humano é a primeira coisa a deixar para trás. Ninguém continua sendo o que era depois de fazer o que eu fiz. Depois de aprender o que aprendi. Mas eu mal me importo com isso agora. (GROSSMAN, 2011, p.401)

Assim, Martin afirma que abriu mão de seu lado humano, ou seja, de sua integridade moral, em troca de poder, para que pudesse permanecer no mundo mágico contra a vontade dos deuses - procurando, inclusive, matá-los. Logo, o dano não é só ao protagonista e seus aliados, mas se faz presente também na vida do antagonista.

Uma afirmação, entretanto, feita ao final do livro por Jane Chatwin, irmã mais nova do antagonista, gera uma dúvida no leitor que só será esclarecida no terceiro livro da trilogia. Jane é revelada, ao final, como a personagem que arquitetou toda a ordem dos fatos para que Quentin e seus amigos chegassem ao local da última batalha com A Criatura. Ela revela ser capaz de voltar no tempo utilizando um relógio feito por anões, e conta como manipulou o protagonista para que o antagonista fosse vencido a qualquer custo - ainda que muitos tenham morrido para que isso acontecesse.

Neste momento, ela diz para Quentin: "Tente não julgar tanto Martin - disse ela, parada na porta. - Plover o molestava 
sempre que eles ficavam sozinhos. Acho que até foi por isso que ele foi pra Fillory, pra começo de conversa. [...] Ele só estava procurando um lugar pra se esconder" (GROSSMAN, 2011, p.431). Tal afirmação dá ao antagonista uma explicação às suas ações que excede os limites do pandeterminismo proposto por Todorov (1981). A justificativa às atitudes de Martin Chatwin é explicada por um meio natural, e não sobrenatural - por mais que todo o evento esteja cercado de elementos sobrenaturais. Além disso, este trecho também sugere, de certa forma, um antagonista do antagonista: Plover, o escritor da série ficcional Fillory e além, cujos livros Quentin lia o tempo todo.

Este núcleo menor de ação será explorado no terceiro livro da trilogia de Grossman (2014), The Magicians Land, no qual Quentin encontra um manuscrito de Rupert Chatwin, que conta como eles foram, de fato, parar em Fillory - expondo os floreios da série ficcional, e o que aconteceu com Martin até que ele se tornasse A Criatura.

Neste manuscrito, Plover é o antagonista de Martin, o protagonista. Rupert, narrador do texto, aponta uma das possíveis consequências da ação de Plover contra Martin: ele é banido de Fillory, segundo Rupert supõe, por não ser mais inocente. Ele afirma "eu não consigo parar de imaginar se, por uma terrível ironia, este não era o exato motivo pelo qual os carneiros pararam de trazer Martin para Fillory. Martin estava fugindo de Plover, mas Fillory não o queria mais. Porque Plover havia desonrado Martin” (GROSSMAN, 2014, p.222-223, tradução nossa) ${ }^{8}$. Esta explicação

8 "And if that is the case I cannot help but wonder too if, in a terrible irony, that was precisely why the rams stopped bringing Martin to Fillory. Martin was fleeing from Plover, but Fillory didn't want him anymore. Because Plover had sullied him." (p.222-223). 
dada por Rupert aos motivos que levaram Martin a tornar-se A Criatura reafirma a teoria de Jeha e Propp, pois apesar de, inicialmente, Plover não sofrer nenhuma consequência por seus atos, ele é morto por Martin depois que ele se torna A Criatura, além de ser desmascarado para a família - ainda que o público de seus livros não saiba de seus atos ilícitos.

Este ato de Martin suscita uma discussão acerca da questão de vingança - uma vez que ele retorna ao mundo real para matar Plover após adquirir poder. Segundo Cota-McKinley, Woody e Bell (2001), vingança é o ato de fazer mal ou causar dano a um indivíduo como retribuição a um mal ou insulto sofrido por meio deste. Os autores afirmam que este ato é característico do ser humano e, assim como a maldade, pode afetar a integridade e segurança tanto daquele que o promove quanto sua vítima. Além disso, para eles, é comum que atos vingativos aconteçam pelas mãos de indivíduos de menor poder contra aqueles que, ao menos inicialmente, representavam o poder absoluto em determinada situação - como é o caso de Plover, um adulto, em relação a Martin, uma criança.

Esta discussão promove, também, um questionamento que relaciona os conceitos de vingança, punição e justiça. Segundo o estudo Justice versus vengeance: motives underlying punitive judgements (HO et al, 2002), a justiça é vista, comumente, como a distribuição de prêmios e punições de maneira proporcional às contribuições e ofensas dos indivíduos. De acordo com essa definição, é possível afirmar que o conceito de justiça abarca tanto a noção de vingança como a noção de punição, com a diferença de que, para os autores, punição pressupõe a ação da lei e de uma relação de igualdade entre os atos cometidos e a severidade da 
punição, ao passo que a vingança é irracional e prima pelo alívio da sensação de desconforto de seu agente - resultando, assim, na desconsideração da noção de igualdade acima mencionada.

Opinião contrária à deste estudo é a do trabalho de Leo Zaibert (2006), uma vez que, em seu texto Punishment and revenge, ele afirma que os conceitos de punição e vingança são, em certo ponto, sinônimos. Para ele, ambos são respostas a algum mal cometido contra um indivíduo, além de serem, também, atos que envolvem emoções, uma narrativa que os justifique e um crivo de igualdade na equação ação-reação. É interessante mencionar que o autor não suscita, em sua comparação, a relação entre os conceitos abordados e a justiça.

Independentemente disto, é possível elencar como justificativa aos atos de maldade e de antagonismo de Martin a noção de vingança. Ao ser vítima dos atos de Plover, o garoto procura vingar-se de seu agressor, o que o leva a caminhos obscuros que corrompem sua integridade moral, como é apontado por Cota-McKinley, Woody e Bell. Isto se relaciona com o conceito de justiça, e abarca todos os pontos característicos dos atos vingativos apontados por Zaibert (2006). Logo, ainda que agindo de maneira não promovida pela lei, Martin promoveu justiça diante da agressão sofrida. Isto pode ser visto pelo leitor como um ato que explica ou até justifica as atitudes do antagonista - questionando, inclusive, a possível "maldade gratuita" que este leitor pode ter, inicialmente, atribuído como característica desta personagem.

Em seu manuscrito, Rupert Chatwin traz outros motivos que podem ser considerados como explicações às atitudes de Martin. 
O primeiro é a ausência dos pais - seu pai foi para a guerra e nunca voltou e sua mãe ficou louca - e o fim súbito da infância de Martin, que foi obrigado a cuidar de seus irmãos, mas não tinha ninguém que cuidasse dele mesmo. O narrador afirma que "quando nossos pais partiram foi Martin, mais do que qualquer outro, que preencheu o vazio em nossas vidas. [...] Mas quem preencheu o vazio de Martin? Só poderia ter sido Fillory. E ela era uma mãe inconstante" (GROSSMAN, 2014, p.218-219 - tradução nossa) ${ }^{9}$.

Assim, percebe-se que Fillory era não apenas o refúgio de Martin contra Plover, como também seu lar, preenchendo o vazio que seus pais deixaram. Entretanto, Martin não era mais autorizado a permanecer no mundo mágico e, por essa razão, violou a lei imposta pelos deuses e fez um pacto com um deles, no submundo de Fillory, vendendo sua humanidade, sua integridade moral, a fim de ganhar poder e permanecer na terra em que amava. Em uma última tentativa de salvar seu irmão, Rupert o questiona ao afirmar que Martin poderia deixar de ser ele mesmo ao vender uma parte de si, ao que o garoto responde: "E se eu não for? O que há de tão bom em ser Martin? Todo mundo o odeia, inclusive eu. Eu preferiria ser outra pessoa. Qualquer uma. Mesmo que eu não seja ninguém” (p.233 - tradução nossa) ${ }^{10}$.

Logo, ao apresentar esses fatos a respeito de Martin, a afirmação em relação à inerência da maldade é questionada. Ao justificar suas ações com situações com a qual o leitor pode se relacionar, como

9 "When our parents left it was Martin, more than anyone else, who filled the void in our lives. [...] But who filled the void for Martin? It can only have been Fillory. And she was a fickle, capricious parent." (p.218-219).

10 Tradução nossa. "What if I'm not?" he said. "what good is martin? Everybody hates him, me included. I'd rather be somebody else. Anybody else. Even if it's nobody". (p.233). 
a perda dos pais, o abuso sofrido e o sentimento de não gostar de si mesmo, o autor cria um nível de verossimilhança no sentido proposto por Candido, com o qual o leitor se identifica e passa a simpatizar com o antagonista.

Desta forma, Martin, o antagonista, que era considerado um monstro por Quentin, o protagonista - um opositor que se apraz de suas maldades e as faz, inicialmente, sem motivo aparente -, ganha a visibilidade e a empatia do leitor, tornando sua maldade interior questionável. Ela provém da raiva, que é interior, mas também é determinada pelo meio ao qual a personagem está inserida e às situações que ocorreram em sua vida. Portanto, conclui-se que, ao contrário do proposto por Jeha, não é correto afirmar que a maldade é apenas inerente ao antagonista, pois ela pode ser também influenciada por forças exteriores que conduzem a personagem a tomar certas ações que resultaram, posteriormente, em sua metamorfose: de criança injustiçada a um monstro cruel.

Retomando Candido, a personagem apresenta características que são comuns aos seres humanos, ainda que sua exposição seja fragmentária. Contudo, esses fragmentos podem mostrar apenas um aspecto da verdade, ou o autor pode propor um trabalho no qual eles se confrontem e exponham a humanidade dessas personagens, deixando ao leitor a função de, verdadeiramente, construir a narrativa das personagens com base em sua própria função cognitiva - como afirma Palmer. Tal pensamento reafirma o proposto por Candido acerca do romance moderno, que procura "diminuir a ideia de esquema fixo, de ente delimitado, que decorre do trabalho de seleção do romancista" (p.44). É precisamente este o excelente trabalho de Grossman, e aí reside a verossimilhança da 
obra por meio das personagens - e da construção e representação de suas mentes.

Por fim, cabe reafirmar, também, a noção de identidade localizada de Alan Palmer. Em nenhum momento, durante toda a trilogia de Grossman, Martin tem voz ativa - seja por meio do discurso direto ou indireto. Em todo momento suas ações são apresentadas com focalização em Quentin, Jane ou Rupert Chatwin. Assim, todas as ações do antagonista são reportadas ao leitor que, com base nessas informações, construirá hipóteses a respeito da mente e pensamentos de Martin. Ao ter suas hipóteses iniciais confrontadas, o leitor é obrigado a ressignificar suas conjecturas a respeito da personagem, atribuindo causalidade às ações do antagonista e atribuindo seus padrões morais reais a elas. Entretanto, todo este processo se dá com base nas informações colhidas pelo leitor a partir dos relatos de outras personagens outras histórias e outras mentes - que, por sua vez, constroem histórias e justificativas para terceiros em suas próprias mentes e, assim, carregam a identidade de Martin consigo.

\section{CONCLUSÃO}

Este trabalho procurou expor a importância da figura da personagem na construção narrativa, bem como sua função no romance e as diferentes perspectivas abordadas a seu respeito através da história. Aos olhos de Brait (1985), Candido (1968) e Palmer (2004), discutiu-se a função da personagem, e pelas teorias de Prado (1968), Campbell (1997) e Propp (2001) estudou-se a função do antagonista. Dentre suas características, os conceitos de maldade, monstro e metamorfose propostos por Jeha (2007), 
Molino (1980) e Todorov (1981) foram expostos a fim de esclarecer a atuação do antagonista.

A título de avaliação e crítica das teorias expostas, analisou-se a personagem A Criatura/Martin Chatwin, antagonista da obra Os Magos, de Lev Grossman (2011), e excertos de outros romances da trilogia de mesmo nome que mencionam esta personagem. Constatou-se, assim, que A Criatura/Martin Chatwin obedece à maioria das afirmações acerca da personagem e do antagonista, como sua característica monstruosa e opositora em relação ao protagonista, bem como sua intencionalidade ao fazer o mal.

Conclui-se, entretanto, que diferentemente do exposto por Jeha acerca da inerência da maldade, esta não é unicamente interior à personagem, mas pode ser resultado da ação de forças exteriores - mesmo que resultem na intencionalidade desta personagem em fazer o mal, como a reação de Martin diante de ofensas sofridas, levando-o a atos vingativos. Além disso, demonstra-se, também, a relatividade da relação protagonista (representante do bem) e antagonista (representante do mal), uma vez que o antagonista do livro Os Magos é também o protagonista do manuscrito encontrado em The Magicians Land, demonstrando que as relações entre bem e mal não estão bem delimitadas neste personagem - assim como não estão com os seres humanos.

\section{REFERÊNCIAS}

ARISTÓTELES (2005). Poética. São Paulo: Cultrix.

BRAIT, Beth (1985). A personagem. São Paulo: Editora Ática.

CAMPBELL, Joseph (1997). O Herói de Mil Faces. 10.ed. São Paulo: Cultrix

CANDIDO, Antonio (1968). "A personagem do romance". In A personagem de 
ficção. 2.ed. São Paulo: Perspectiva. p.39-62.

COTA-MCKINLEY, Amy; WOODY, William D.; BELL, Paul A. (2001). "Vengeance: Effects of Gender, Age, and Religious Background". In Aggressive Behavior, Wiley Liss, Inc.27, 343-350.

GROSSMAN, Lev. (2011). Os Magos. Barueri: Manole. (2012). O Rei Mago. Barueri: Manole. (2014). The Magician's Land. New York City: Penguin Books.

HO, Robert; FORSTERLEE, Lynne; FORSTERLEE, Robert; CROFTS, Natalie (2002). "Justice versus vengeance: motives underlying punitive judgements". In Personality and Individual Differences, Elsevier Science Ltd.

JEHA, Julio (2007). "Monstros como metáfora do mal". In Monstros e Monstruosidades da Literatura. Belo Horizonte: Editora UFMG.

MOLINO, Jean (1980). "Le fantastique entre l'oral et l'écrit". In Europe - Revue Littéraire Mensuelle, Paris, 611, 32-41.

PALMER, Alan (2004). Fictional Minds. Estados Unidos da América, University of Nebraska Press.

PROPP, Vladimir I (2001). Morfologia do Conto Maravilhoso. CopyMarket.com. TODOROV, Tzvetan (1981). Introdução a literatura fantástica. 2.ed. São Paulo: Perspectiva.

ZAIBERT, Leo (2006). "Punishment and Revenge". In Law and Philosophy, Springer. 


\section{\1}

\section{ENTREVISTA COM O ESCRITOS RICARDO VIRHUEZ VILLAFANE}

Recebido em 24 mar 2019. Marisa Martins Gama-Khalil é Doutora em Estudos Aprovado em 04 abr 2019. Literários pela UNESP e Pós-Doutora pela Universidade de Coimbra. É professora da UFU e pesquisadora Produtividade em Pesquisa pelo CNPq. Atua no Programa de Pós-Graduação em Estudos Literários e no PROFLETRAS da UFU. Tem publicações na área da Literatura Fantástica, incluindo ensaios e organização de livros, como Nos labirintos do medo: estudos sobre o medo na ficção; No território de Mirabilia: estudos sobre o maravilhoso na ficção; As literaturas infantil e juvenil ... ainda uma vez. É líder do Grupo de Pesquisas em Espacialidades Artísticas (GPEA/CNPq), atuando nos campos da literatura fantástica, da narratologia e do letramento literário. Lattes: http://lattes.cnpq. br/9430138689219946. E-mail: mmgama@gmail.com 


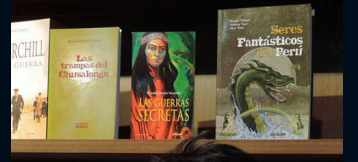

Ricardo Virhuez Villafane é escritor e pesquisador peruano, diretor geral da Revista Pasacalle e da Revista Peruana de Literatura. Cursou Direito e Ciência Política, e posteriormente Linguística, na

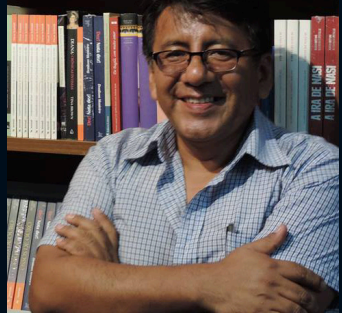
Universidad Nacional Mayor de San Marcos. Ainda aos dezessete anos ganhou dois prêmios, um como escritor literário, com o conto "José María Arguedas"; e outro com o ensaio "José Joaquín Inclán". Atuou como editor geral da Noticia Hispanoamericana, Nova York, e editor da revista TAXI New York em espanhol. Além de sua atuação como ficcionista e ensaísta, tem trabalhos da área do teatro, uma vez que é autor da peça El cielo azul, foi diretor do Grupo de Tetaro Tumueca e foi professor na Escola de Berlas Artes Victor Morey Peña de Iquitos. Algumas de suas produções ficcionais são: Las hogueras del hombre (crônicas), El cielo azul (peça teatral), El periodista (novela), Voces (poesia), El olor del agua (contos), Volver a Marca (novela), Rumi y el pincullo mágico (novela), El Dios Araña (novela), Nina y la casa abandonada (novela), Nina y los yanapumas (novela), Rumi y el monstruo del Ucayali (novela), El campeón de marinera (novela). No campo da ensaística, crítica e historiografia literária, tem importantes produções, dentre elas: como Seres Fantásticos del Perú, Seres Fantásticos de la Amazonía, Letras indígenas en la Amazonía peruana, Marca: historias y tradiciones, Leyendas Tenebrosas del Perú: Las historias de los seres más espeluznantes de la tradición oral peruana.

P.: Desde a época da Antiguidade Clássica, personagens maravilhosas - míticas, legendárias, mágicas - habitam o imaginário de todas as culturas, bem como se inserindo de modo incidente na ficção. Como o senhor compreende essa hegemonia do maravilhoso mesmo após revoluções sociais que primaram pelo racionalismo? 
R.: Desde la literatura, los seres fantásticos son un tipo de personajes que cumplen una función narrativa específica: representar a las fuerzas de la naturaleza. En la tradición oral de la antigüedad, los personajes podían ser humanos - fantásticos. Los personajes humanos representaban las contradicciones de la cultura, las contradicciones de la vida, el amor, los valores y disvalores, las guerras y la muerte. Mientras que los seres fantásticos, representados por seres extraordinarios con poderes más allá de las posibilidades humanas, representan las fuerzas incomprensibles de la naturaleza y los sucesos extraordinarios. En ambos tipos de personajes, es el poder de la ficción lo que prima. La ficción construye historias y personajes, cuya utilidad es variadísima en la sociedad. La ficción sirve para entretener, para convertir en grandiosos los sucesos triviales, para explicar los hechos, las ideas y los sueños mediante símbolos y parábolas. La ficción es la realidad inventada y paralela de la realidad concreta. Para ello, la ficción usa el lenguaje metafórico, es decir, los relatos, cuentos, anécdotas, todas las posibilidades de la narración. Cuando surge la propiedad privada, los grupos de poder, las familias con dinero y ejércitos, estos grupos intentan convertir la ficción en "verdad". La religión, por ejemplo, convierte los hechos sobrenaturales de un cuento literario en una verdad incontrastable. La política convierte las ficciones literarias de sociedades más o menos respetuosas en verdad social. Incluso en nuestra época, las "ciencias sociales" convierten la ficción religiosa y política en "verdad" y en "conocimiento científico", cuando atribuyen a los pueblos originarios supuestas prácticas 
mágicas, chamánicas, místicas, totalmente ajenas a ellos y más bien trasplantadas de sociedades europeas y asiáticas. Como vemos, la tradición oral no es sinónimo de irracionalidad, sino más bien de una estricta racionalidad fundada en el lenguaje metafórico. No hay nada más lógico, racional y estructurado que un hermoso cuento de la tradición oral, ya sea que intervengan personajes humanos o fantásticos. Lamentablemente, el racismo europeo-yanqui y la colonialidad latinoamericana no han sabido comprender la profunda belleza de las tradiciones orales. Las han visto como "verdad" cuando se trata de ficción, de poder fabulador, de placer de narrar. Y la ficción es patrimonio de la humanidad y nos ha acompañado y acompañará por siempre. (grifos do autor entrevistado)

P.: Na Amazônia, podemos dizer que os seres maravilhosos ainda têm grande força no cotidiano das comunidades? Por quê?

R.: Los personajes fantásticos por supuesto que tienen una gran fuerza e intervención cotidiana en las comunidades, pero no porque creamos que son "verdad" o, peor aun, "dioses" en los que creen mediante una fe irracional. En absoluto. Los seres fantásticos que intervienen en la tradición oral de los pueblos amazónicos son personajes literarios, tratados como personajes literarios y reconocidos como personajes literarios. Por esa razón, la gente se burla de ellos, los tratan con humor, los regañan o persiguen, en fin, son parte de aquello que una de las técnicas del arte de narrar precisa: la verosimilitud. Es decir, en la oralidad es importante contar una historia de la manera más vívida posible, y la técnica de la verosimilitud en la oralidad es el testimonio, afirmar "yo lo viví" o "le pasó 
a mi padre" para que los oyentes sientan la narración más cercana, se apropien de ella, lo vivan tan intensamente, como un lector de libro o un espectador de teatro o de cine. Para los extraños a los pueblos amazónicos, esta verosimilitud es vista como "creencia" o peor como religión, cuando no hay nada más ajeno a la Amazonía que dioses y religión. Si viéramos la tradición oral sin prejuicios, sin racismo, sin los anteojos del colonialismo contemporáneo, descubriríamos una literatura oral hermosa y llena de personajes fantásticos inolvidables.

P.: Para Alejo Carpentier, o real maravilhoso tem o seu ponto de emergência relacionado a uma percepção incomum da realidade e esta deve estar associada a um ato de fé, de uma crença. O senhor vem considerando em seus estudos os postulados der Carpentier? Entende que a noção de real maravilhoso representa bem a vivência das comunidades amazônicas em relação aos seres maravilhosos?

R.: Las ideas de Alejo Carpentier sobre lo real maravilloso, como las de Gabriel García Márquez sobre el realismo mágico, son ideas europeas expresadas por latinoamericanos que buscan encontrar en lo exótico lo esencial de nuestro continente. Carpentier considera que lo abrumador, lo retórico, lo abundante es la característica de Latinoamérica, y desarrolla una literatura barroca, la cual en realidad es volver a los fueros de la literatura medioeval española y portuguesa, barroca y retórica, donde se escribe mucho y se dice poco. Lo curioso es que casi toda la literatura latinoamericana tiene su punto de partida en la tradición oral como tema, como paisaje, como telón de fondo, incluso para diferenciarse de lo local y mostrarse más europeo. 
Por ello, han arrinconado a la rica tradición oral al museo de los "mitos y leyendas", folclore, supersticiones, etc, cuando precisamente en Latinoamérica, Europa y Asia la tradición oral ha sido la base de la literatura escrita. Pero mientras en Europa se reconoce este hecho, y los relatos griegos, los eddas nórdicos, las recopilaciones de Basile, Afanasiev y los hermanos Grimm son motivo de orgullo, la colonialidad latinoamericana nos impide reconocernos en nuestra tradición oral. Por ello, la propuesta de Carpentier es un acto religioso europeo antes que un acercamiento humilde a la rica ficción americana y a los seres fantásticos que la habitan.

P.: Fale-nos sobre a presença do maravilhoso (ou dos seres maravilhosos) em suas produções ficcionais.

R.: Estoy recopilando cuentos populares para dos colecciones de recopilación: la primera, basada en las naciones originarias del Perú, que son 55 pueblos, la mayoría amazónicos y algunos andinos. Cada tomo estará dedicado a los cuentos de cada pueblo. Por ejemplo, Cuentos shipibos, Cuentos Asháninkas, Cuentos awajún, Cuentos aimaras, etc. La segunda colección es recopilar cuentos por regiones del país. Así tenemos, Cuentos tradicionales de Áncash, Cuentos tradicionales de Cusco, etc. Eso en cuanto a trabajo de recopilación, que lo hago luego de trabajar en base a los personajes fantásticos y de haber publicados los libros Seres Fantásticos del Perú y Seres Fantásticos de la Amazonía. De otro lado, en cuanto a mi propia creación, he escrito algunas novelas donde intervienen seres fantásticos tradicionales, como en Las trampas del Chusalongo y Cuentos de selva. Asimismo, en preparación el 
ensayo Literatura y tradición oral, y la reedición de mi libro Letras indígenas en la Amazonía.

P.: Conte-nos um pouco sobre o processo de construção dos seus livros Seres fantásticos do Peru e Leyendas Tenebrosas del Perú: Las historias de los seres más espeluznantes de la tradición oral peruana._O que o senhor considerou quando da seleção dos seres fantásticos e das lendas?

R.: Estas colecciones de libros con personajes fantásticos nacen luego de una recopilación más o menos amplia de cuentos populares. De esos cuentos, luego de analizar las características de los personajes, seleccionamos a los menos intervenidos, los que poseen menos elementos coloniales y por tanto son más antiguos. Ese fue el criterio de selección. Los libros que contienen seres fantásticos no son propiamente recopilación, sino el resultado de extraer sus características de diversos cuentos y luego redactamos describiendo sus habilidades extraordinarias. En el caso de Leyendas tenebrosas, fueron cuatro libros breves para el diario La República, que los publicó en grandes tirajes y donde se recrearon las historias. Fue puro trabajo de recreación, de inventar historias de terror con el personaje de la tradición oral como generador de la narración. Otro punto a tener en cuenta es el siguiente: creo que algunos personajes fantásticos poseen sagas narrativas, es decir, son numerosos cuentos para un solo personaje. Esa es la novedad de nuestro trabajo. 


\section{UM CONVITE ÀS MONSTRUOSIDADES EM VIALE MOUTINHO}

Luciana Morais da Silva (UERJ)

Recebido em 18 jan 2018. Luciana Morais da Silva é Doutora em Letras - Teoria da Aprovado em 28 jan 2018. Literatura e Literatura Comparada - pela Universidade do Estado do Rio de Janeiro e Doutora em Letras Literatura de Língua Portuguesa - pela Universidade de Coimbra, em regime de cotutela (2016). Mestre em Letras - Literatura Portuguesa - pela Universidade do Estado do Rio de Janeiro (2012) e Mestre em Letras Vernáculas - Literaturas Africanas - pela Universidade Federal do Rio de Janeiro (2012). Possui graduação em Letras - Português/ Literaturas pela Universidade do Estado do Rio de Janeiro (2005-2009). Tem experiência na área de Letras, com ênfase em Linguística, Letras e Artes, atuando principalmente nos seguintes temas: insólito ficcional, estudos narrativos, gênero literário, memória, história, mundos possíveis, narrativa, teoria literária, literatura comparada, literatura portuguesa contemporânea, literatura africana contemporânea, literatura brasileira contemporânea, literatura galega contemporânea e literatura infantil-juvenil, com artigos publicados nas referentes áreas. 
O livro Monstruosidades do tempo do infortúnio, do escritor José Viale Moutinho, com ilustrações de Alberto Péssimo, lançado em abril de 2018 pela Letras e Coisas traz em seu inventário a materialidade do mórbido e do monstruoso, permitindo que cada leitor enverede pelas cores e sentidos de narrativas curtas intrigantes e, sem exageros, amedrontadoras. A vileza

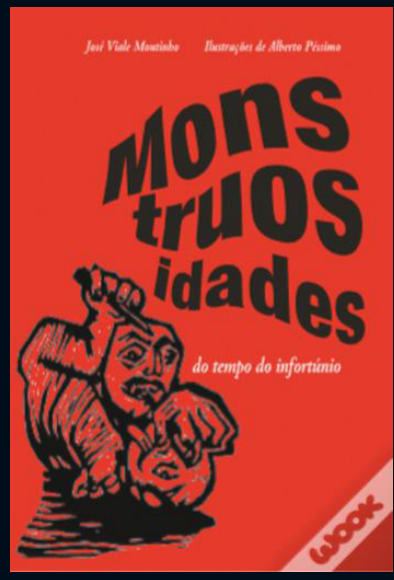
presente no constructo ficcional do escritor toma de empréstimo o inventário próprio de cada leitor para desconstruir certas crenças a partir da própria ressignificação de símbolos e significados.

A morbidez observada em sua compilação textual é evidenciada pela presença não sistemática de um conjunto de acontecimentos não sequenciais desvendados a cada nova página de seu livro. As narrativas curtas que compõem seu livro estruturam-se por meio de pequenos recortes circunstanciais da vida; seja de homens, seja de não homens. Assim, o surgimento do in-sólito e do não natural se dá exatamente pela naturalidade com que os acontecimentos vão sendo narrados e desvendados pela escrita astuta e inquiridora de Viale Moutinho.

O monstruoso desenvolvido pelo autor no referido livro decorre tanto do aporte sobrenatural, quanto do natural, pois cada texto apresenta uma experiência singular de contato com as monstruosidades quotidianas em mundos possíveis ficcionais, quer fruto de deformidades físicas, quer fruto de deformidades psíquicas. As histórias engendradas pelo escritor constituem-se pela exceção 
com humanos e/ou seres não naturais à margem, conjugando laços borrados seja pela amargura, seja pela satisfação, em movimentos temporais não delimitados em uma linha concisa, mas borrados em função de cada contexto narrativo.

Os monstros presentes na confecção da obra literária de Viale Moutinho são preenchidos pela configuração de suas monstruosidades, compondo, desse modo, processos de fabricação de personagens a partir de suas estruturas modelares. Nesse sentido, as monstruosidades que constituem os monstros do autor produzem múltiplos sentidos para cada narrativa, principalmente pelos variados elementos e significados derivados das estratégias de construção empregados. Seus monstros acabam, portanto, nem sempre sendo formulados a partir do olhar comum ou de monstruosidades conhecidas, visto que o escritor utiliza caminhos diferenciados para evidenciar anomalias sociais.

Publicada em capa dura, a obra de Viale Moutinho tem o formato deforme das letras ilustradas já na capa, instigando a procura de significados para as monstruosidades lá impressas, afinal, o tempo do infortúnio apresenta suas "mons-truos-idades" por meio de um jogo de palavras de curioso resultado. Talvez não seja proposital, contudo, a separação da palavra "-idades" ao fim possibilita uma reflexão acerca do diálogo entre o tempo e as idades. A coloração vermelha da continuação do título, "do tempo do infortúnio", ganha novo sentido, principalmente devido ao destaque fornecido pela cor, pois, como é sabido, o tom vermelho além de ser uma cor primária é, ainda, um tom vibrante e diretamente ligado à memória do sangue e, de certo modo, à vida humana e/ou animal. A coloração vermelha também está presente na sobrecapa com ilustrações em preto. 
De coloração vibrante e bastante simbólica, as ilustrações de Alberto Péssimo são constituídas pelas cores vermelho, marrom e preto, indicando uma opção não uniforme e nem multicolorida, entretanto, inquiridora no que tange a constituição das monstruosidades presentes nos textos contidos no livro. Esse produto entre escrita e ilustração é uma obra com possibilidades variadas de leitura, principalmente pela significação das cores e dos elementos não-verbais. Cada história teria, por conseguinte, uma representação pictórica e também uma cor representativa, instigando o leitor a enveredar-se pelas bifurcações das páginas multiformes do livro.

O livro do jornalista e ficcionista nascido em Funchal, Portugal, divide-se em vinte e oito (28) narrativas curtas ilustradas. Demonstrando um verdadeiro conhecimento sobre contar histórias, Viale Moutinho produz um livro de imersão em pequenos eventos do quotidiano ocorridos em terras desconhecidas, seja na aldeia das cobras, seja em montanhas longínquas. O medo presente em seu livro não se aproxima do horror ou do terror, contidos em monstruosidades já conhecidas e aterrorizantes, a leitura permite vivenciar o medo mais poderoso e mais antigo que, segundo Lovecraft (2007), é o medo do desconhecido.

O desconhecido promove, em seu livro, certa sensação de contato com novas culturas, porém os infortúnios da vida, inesperados e desconexos, permitem ao leitor vivenciar os caminhos tortuosos do medo produzido pelo devir. O que pode, por exemplo, acontecer com uma personagem que divide as páginas com o demônio? Qual seria o futuro do homem ao lado do desconhecido ser insólito? Enfim, trata-se apenas de uma das 
narrativas: "Negócios com o demônio" (p.139-140). Em mundos de hipócritas e falácias bem construídas, as hipóteses de destruição pelas chamas ou de chagas deixadas pelo homem no mundo animal, encontradas em diferentes narrativas, seriam marcas textuais de infortúnios escolhidos, contudo, inesperados diante da ignorância das próprias monstruosidades derivadas do humano.

A obra literária de Viale Moutinho revela, desse modo, uma potencial característica de composição, sendo um constructo narrativo culturalmente delimitado por dados históricos e, também, por seres míticos e marcados por sua simbologia. Os caminhos determinados pelas próprias histórias permitem um amplo percurso por mundos possíveis ficcionais amplificados pelos possíveis determinantes presentes em sua composição (SILVA, 2016).

As instruções dadas aos leitores pelo autor das "crônicas" do infortúnio prenunciam certezas desfeitas e ressignificações a cada nova página. Nos mundos possíveis confeccionados por Viale Moutinho, o convite primeiro é para que se percorram os interstícios d'“A aldeia das pobres cobras" (p.7-13), questionando o motivo de os humanos nada aprenderem com os míticos seres rastejantes, principalmente ao serem insensíveis diante do desconhecido. O destaque do início ao fim da história é dado, em certo sentido, à desumanização do humano, o devir monstro pelo medo do desconhecido.

No texto dois, "Não sou Pablo de Siguenza" (p.15-17), mais uma vez o medo torna-se protagonista na consecução da história de alguém que não é quem parece. As marcas ficcionais plantam a dúvida e permitem sua ascensão, pois nem mesmo as 
personagens centrais das narrativas permanecem manifestando seus questionamentos sobre os acontecimentos a sua volta. O protagonismo presente no texto é volátil como o local da consecução da história e, desse modo, o não natural é manifestado pela concretude das excepcionalidades.

Em “Um penhasco no Douro" (p.19-22), terceira narrativa do livro, cada leitor é convidado, já no título, a conhecer uma região específica de Portugal, o Douro, dividindo com a personagem principal as apreensões diante de um desafio. A ausência de certezas carrega a narrativa para o campo das especulações e das ações grandiosas perpetradas por meio de magia. De fato, não se pode afirmar nada sobre as decisões do protagonista, nem mesmo com relação a suas demandas, no entanto, a dúvida relativa ao futuro permanece a ecoar até o próximo virar de página.

Na sequência, o receptor desavisado depara-se com a "Fábula" (p.25), uma micronarrativa marcada pela intertextualidade e, ainda, por sua relatividade diante dos acontecimentos da vida. Nela, os limites entre o ser e o parecer são mais uma vez postos em causa e, o processo de ressignificação, estabelecido pelo título e pela homenagem prestada a um reconhecido escritor de nacionalidade espanhola, evoca uma ampliação dos sentidos primeiros dos elementos discursivos.

Na quinta narrativa, o leitor caminha pela "Fossa Comum" (p.27-29), percebendo juntamente com as personagens como algumas descobertas podem ser tortuosas e dolorosas. Nos mundos narrativos, as personagens lamentam por seus pés doloridos e questionam as certezas dos caminhos, contudo, não há 
o questionamento a respeito da passagem do tempo. Esse de modo traiçoeiro deixa rastros seja pelo uso de vocábulos carregados de significados, seja pelo incômodo causado por uma caminhada. A fossa comum revela-se para as personagens como um encontro de gerações, que se colocam reunidas por meio de pequenas revelações e grandes encontros.

Talvez não propositalmente, mas de maneira bastante singular, a fossa prepara para o encontro permitido no texto seis (6), "A feira do livro à porta do cemitério" (p.31-33), em que o espaço do terror e do medo, os cemitérios de muitas narrativas parece uma porta para novas e outras leituras. No entanto, a feira acaba por ser inconveniente e aparentemente inútil. Afinal, qual seria a utilidade d'“A feira do livro à porta do cemitério"? Quais seriam suas possibilidades de compra e venda? O efeito revelado pela narrativa vincula-se aos desdobramentos da feira e em certo sentido ao destino de livros à porta do cemitério. Trata-se de um texto irônico, produzido em torno de muitas questões e que possibilita um variado leque de dúvidas, principalmente por focar na perenidade do conhecimento e efemeridade do livro.

Na sétima narrativa, "Uns dias de repouso" (p.35-36), a serenidade presente em uma viagem de descanso revela elementos de uma cena quotidiana, porém marcada por uma crueldade mostrada a cada novo passo do protagonista. Seu percurso e suas percepções do entorno deixam caminho para questionamentos sobre a origem do mal, da presença do maligno nas ações de simples humanos. Ainda que os interstícios textuais pareçam apontar para o comum, o corriqueiro, certos encontros marcam a ascendência do infortúnio quer para o protagonista, quer para aqueles que o incomodam. 
No texto oito (8), "A vingança ao virar da esquina" (p.39-42), o autor, mais uma vez, faz com que o leitor caminhe pelas veredas da violência e, em certo sentido, do mal. O tema da vingança já desvendado no título assusta e inquieta, permitindo a cada leitor vivenciar os caminhos da vingança a partir de uma história muito bem desenhada, mesmo que permeada por vazios e ausências. A capacidade de diálogo das histórias de Viale Moutinho com um inventário cultural muito bem delineado possibilita, inclusive, a alusão do autor a aquiescência do deífico diante de outras tantas mazelas do humano. O modo como o escritor vai produzindo os questionamentos no decorrer da narrativa permite, por conseguinte, perceber a dualidade também das alusões não ingênuas, mas inquiridoras, que ele acaba fazendo daquilo que vem do alto, dos céus.

Em “A traição da mulher do bombeiro" (p.45-46), a ironia abre espaço para se conjugar a traição no espaço privado com as traições do espaço público e, assim, o escritor promove uma rememoração de datas marcantes para seu país de origem. Com isso, ele tensiona as liberdades e o quanto elas importam para o cidadão que está na base da sociedade. A morte, tema recorrente em suas narrativas do infortúnio, mais uma vez aparece, produzindo efeitos múltiplos e deformes na configuração da estrutura textual, tanto que no fim o leitor não sabe muito bem os limites da variedade de sentidos oportunamente apontados por Viale Moutinho.

Novamente, o convite exposto na narrativa "Balada da tarde na poltrona" (p.49-51) perpassa o encontro com a morte e também o mergulho em histórias e livros, contudo, os livros ironicamente perdem-se no percurso de leitura com personagens ironicamente 
presas à margem, vivenciando cenas de romances policiais ou construindo-os. A história confecciona dúvidas acerca do espaço habitado pelo protagonista, pois não se sabe muito bem se suas vivências compõem as páginas dos livros ou se são compostas por elas. Fato é que os mundos possíveis são construídos por meio do contato com livros e também pela contínua reclamação da personagem quanto ao descarte de algumas páginas do livro.

Outra narrativa bastante instigante é "A descida do anjo" (p.5354), texto em que Viale Moutinho coloca seus leitores em contato com lendas e vivências de uma festa típica. As personagens contam histórias e também comemoram "a descida do anjo", perpetuando com rituais festivos um acontecimento popular. Isso significa dizer que o autor aparentemente relata a experiência de uma festividade típica de um vilarejo na região do que se conhece hoje como Espanha. As apreensões possíveis dos mundos elaborados pelo escritor conjugam-se, nesse caso, a fortuna possibilitada pela intervenção do alto, do deífico, que, por sua vez, pode produzir modificações benéficas na condição do ser humano.

O contato com a divindade mais uma vez está presente em "Contemplação do deserto" (p.57-60), narrativa com uma personagem que possui "um deserto a começar à porta [...][de sua] casa" (p.57), portanto, um ser desafiado pela natureza, uma vez que ameaçada pela incapacidade de perceber "o bordo do deserto" (p.57). Destarte, as incapacidades e fugacidades da personagem demonstrarem-se falaciosas, ele planeja mudar o deserto de sítio, já que o homem rompe suas limitações, adquirindo, desse modo, conquistas e amizades não naturais. Um homem modificar completamente o lugar de um deserto não seria, de certo, uma 
capacidade humana. Ou seria? Enfim, a narrativa constrói-se por meio das inquirições e diálogos entre a personagem e outros desconhecidos, encontrando também com vozes deíficas, não se sabe se indicadoras da intervenção divina ou se marcas pungentes dos devaneios de alguém na janela.

Em “Roncos de Oliveira Velha” (p.63-64), Viale Moutinho convida seu leitor a adentrar uma história esperada, corriqueira, sólita. Nela, porém, fabrica personagens animais com características humanas, indicando processos de antropomorfização, principalmente ao desenvolver diálogos e atitudes humanas. Assim, os seres humanos ou não se constroem tomados por uma aura não natural, pois compostos pela maravilha, mas vivos na esteira da descrença e do apagamento. O devir, talvez apagado pela descrença, formula-se aqui não pelo medo, e sim pela indiferença.

A construção de um futuro, se for possível ter futuro, também está exibida n'“O castelo do mau vizinho” (p.67-71), narrativa em que o mal vem do alto, não dos céus, mas da ausência de bondade no coração de um soberano. A história adentra também os limites do maravilhoso por tratar de castelos e feitos grandiosos, porém não há benevolência nas atitudes do mau vizinho, apenas falta de boas ações. É uma personagem caracterizada pelo medo e por sombras, pois nada se faz à sua volta pelo risco da perda. 0 mal gerado pelas atitudes grotescas do mau vizinho espalha-se, denotando a espantosa capacidade de expansão do que não é benéfico e, assim, todos à volta do castelo parecem submetidos e ameaçados por presenças insólitas e atitudes contraditórias e, em certo sentido, perpetuadoras do mal. 
Mais uma vez o insólito atua na narrativa de Viale Moutinho. Em "O desvio da via férrea" (p.73-75), há uma história inesperada dentro da construção de uma inaudita conversa e, assim, cada personagem parece destinada a enxergar fantasmas que, ao fim, não se sabe muito bem se seriam seres naturais ou sobrenaturais. Nesse sentido, a condição da personagem em perceber-se em um mundo marcado pelo empírico e pelo metaempírico contribui para uma indefinição de efeito contínuo até após o desfecho narrativo. Tratando-se de dúvida e de curiosidade, a narrativa não poderia acabar de outra maneira, deixando estigmas da concretização da irrupção do insólito ao fecharse com a frase: "... a voz fanhosa de um locutor que dizia que nada estava a acontecer em parte nenhuma" (p.75). Essa possibilidade de não ocorrência de nada em lugar nenhum instiga a descoberta e deve-se, no decorrer da leitura de Viale Moutinho, questionar exatamente a naturalidade do sobrenatural, pois é na fugacidade do inaudito que se constituem seus tempos do infortúnio.

No texto dezesseis "Nocturno para passeio" (p.77-78), o escritor não trata de marcas sobrenaturais, nem de maravilhas, mas da condição humana e das insólitas construções contemporâneas, pois é possível na vida quotidiana olhar-se o outro e, simplesmente, não ver. Verdade ou mentira? Não se tem respostas na narrativa, apenas uma construção marcada pela efemeridade da perpetuação do momento, tendo, como devir, as elucubrações de alguém que sobrevive no escuro. Entre promessas vãs e projeções talvez irrealizáveis, as personagens do autor caminham automáticas pela multidão afligidas por suas próprias misérias.

As chamas não referidas no presente percurso, mas reincidentes nas composições das "monstruosidades" de Viale Moutinho, 
estão inquestionavelmente evidenciadas em "O incêncio do velho alfarrabista" (p.81-82), perpetuando as dores e os dissabores da consumação derivada de incêndios e de burocracias. Em tempos do infortúnio, a narrativa promove reflexões sobre o destino de livrarias e livreiros, pois, mais de uma vez, as chamas a findarem culturas e conhecimentos acabam desimportantes frente às demandas quotidianas. Desse modo, o questionamento levantado na narrativa não se atém aos limites textuais relacionados às manifestações do insólito que cercam a personagem, mas extrapola limites ao buscar respostas sólitas para uma crítica contundente diante do medo do devir.

A narrativa "Tratamento de um suspeito" (p.85-89) dialoga diretamente com a narrativa de um importante escritor brasileiro do fantástico, permitindo uma imersão nesse mundo insólito e não natural do devir apresentado por Viale Moutinho. Nela, a personagem encontra-se perdida no desconhecimento e temeroso espaço do devir, pois pelas não respostas derivadas de sua presença em um ambiente de inquirição e de desventura, apenas por não saber responder aos questionamentos que lhe são feitos, o protagonista acaba aprisionado. Assim, o medo e a angústia construídos contribuem para a produção de uma narrativa profundamente insólita, tensionadora da racionalidade, exatamente por pôr em xeque as liberdades de ir e vir e de dar respostas.

A privação de liberdades volta a replicar-se em "Quem quer dormir para sempre" (p.91-93), uma vez que a personagem principal questiona-se sobre as metafísicas da vida humana, refletindo sobre as possibilidades em torno da vida e da morte. Dessa maneira, seja mencionando autores conhecidos, seja 
citando um mito, a personagem busca explicações sobre a vida e sobre a morte, produzindo principalmente desdobramentos incômodos e inesperados para sua vida. Nos mundos possíveis ficcionais, o castigo para os suicidas aparece assemelhado ao da excomunhão, tornando o morto alguém à margem, entretanto, na narrativa não se sabe ao certo os percursos nem os caminhos da personagem. Há, com certeza, um percurso bastante significativo para os leitores que pouco a pouco se descobrirão questionando sobre o destino fortuito ou não da personagem. Trata-se de uma narrativa questionadora e multifacetada a ser desvendada pelo leitor atento.

Na sequência dos desafios empreendidos por Viale Moutinho acerca da morte, o leitor é recebido por Cervantes em "A toupeira" (p.95-102) e, então, é apresentado a D. Saturnino. Na narrativa do cavaleiro leitor, seu nariz constantemente entre os livros leva-o pelo caminho entre o confronto de sua realidade e a vivência das aventuras do Quijote. Assim, cada percalço é discutido pelo viés da imaginação e da concretude do ocorrido, contudo, em certos momentos não se sabe mais os limites entre os mundos, pois os embates entre as personagens permitem o crescimento da desconfiança e da certeza da irrupção do insólito na constituição da personagem. A intertextualidade presente no escritor possibilita ao leitor vivenciar novas aventuras e, ainda, ir ao encontro do "herói" de Cervantes, construindo novas perspectivas e ampliando a significação de mais essa narrativa do tempo do infortúnio.

Sem abandonar a temática da revelação de feitos históricos e produção de heróis imaginários, o escritor envereda pela construção d'“O romance da minha vida" (p.105-106), narrativa alinhavada 
pela angustia da busca de autoria para contar uma história. Nesse contexto, Viale Moutinho fabrica uma personagem decidida a tornar-se o protagonista de uma história sem autor e, assim, destinado ao anonimato, já que uma história só pode ser contada tendo quem a escreva. Nesse vai e vem, a personagem garante aos seus leitores uma interessante reflexão sobre sua autoconstrução. Mais um conto de idas e vindas inquietantes e maravilhosas.

A necessidade de encontrar um autor para uma história cede espaço para em "O fim da história” (p.109-111) ter-se o encontro com alguém cansado da investigação, determinado a deixar-se guiar pelos acontecimentos, sem mais questioná-los. Nessa narrativa, o devir ameaçador parece derivado do conhecimento da História, da confecção do saber, pois há a construção de um nítido esgotamento da personagem e, então, uma desistência do saber mais formal. Feito isso, a personagem mergulha em novos encontros, porém com o seu passado, com pessoas já suas conhecidas. Assim, a narrativa brinca com os sentidos da investigação, do conhecimento Histórico, ao produzir caminhos para a reflexão e descoberta pelo viés da dúvida e também da negação diante do conhecimento. O autor envereda pelas sendas do insólito ao estranhamente perpetuar os caminhos da História no quotidiano de uma personagem decidida a não reconhecer-se por suas histórias.

Na narrativa "Cabeça de serpente" (p.113-114), o autor igualmente constrói caminhos pela história e ainda pela memória ao produzir reflexões sobre a constituição familiar do protagonista. O percurso da personagem, apesar de conciso, revela a monstruosidade existente nas relações humanas, demonstrada principalmente pela cobiça e o desdém animalizador e anormal 
que um humano pode ter pelo outro. Em tempos de relações não construídas, resta às gerações futuras "a decepção" (p.114).

A "Página da vida de um sem-abrigo" (p.117-120) começa nas calçadas, com um conjunto de questionamentos que, de certo, permitem ao leitor duvidar sobre os caminhos da narrativa de Viale Moutinho, percorrendo mesmo a estrada da desconfiança e do descaso. Entretanto, os infortúnios estão expressos tanto nas escolhas do sem-abrigo quanto na exposição da rua, que o leva a não ter liberdade: "o desrespeito pela liberdade individual" (p.118), como a própria personagem observa.

Nessas singularidades percorridas por Viale Moutinho, os tempos e os espaços tendem a parecer corriqueiros, com narrativas que espelham histórias comuns, quotidianas. Todavia, algumas dessas histórias enveredam pelas nuances da perda da liberdade, das monstruosidades que vilipendiam a humanidade, a sociedade, invertendo a naturalidade das coisas para dar visibilidade ao infortúnio que pode acometer a cada um e a todos os dispersos na multidão. Afinal, como se estabelece desde o título da obra, há monstruosidades em tempos de infortúnio ou não? São tais monstruosidades apenas da ordem da construção de monstros? 0 leitor é, portanto, convidado a descobrir como se configuram os monstros em Viale Moutinho.

Na continuação, o escritor, em "Os eruditos" (p.123-125), coloca lado a lado "quatro ou cinco eruditos que [...] [se odiavam] mutuamente" (p.123), estabelecendo um percurso de conflito desde a primeira linha da narrativa. Com o ódio como elemento constante presente no texto, as descobertas centram-se na construção de 
monstros do quotidiano, marcados pela faceta inigualável de roubar a paz de outros. A narrativa trata de livros, do contrato entre patrões e empregados e entre clientes e comerciantes, denotando configurações sociais estabelecidas e o modo como tais relações são construídas. Assim, o percurso das personagens indica as múltiplas histórias que em um mesmo espaço se constituem.

Em outra história marcada pela presença de animais e por condições adversas advindas do fogo, o escritor confecciona personagens contraditórias e apáticas em "A tragédia dos hipócritas" (p.127-129). Nessa história, o teatro dos hipócritas permanece funcional enquanto todo o cenário arde. O percurso narrativo revela ausências monstruosas, pois se deixa de dar importância à vida humana, resultando em muitas mortes, mas que estranhamente não ganham maiores proporções. Com isso, percebe-se como a desumanização apresenta-se como resultante de anormalidades comuns, afinal, um lugar pegar fogo não é incomum, insólito é não existir os que se importem. Isso significa dizer que como produto da narrativa de Viale Moutinho tem-se um conjunto de reflexões possíveis de se realizarem por meio das múltiplas leituras que delineiam nas páginas de seu livro.

Em o "Encontro na editora" (p.131-136) mais uma vez o autor tratará de livros e de leituras, ao permitir uma caminhada pelos interstícios da produção literária, o escritor conduzirá cada leitor à descoberta das pressões que incidem sobre o ato de escrever e, no caso, de publicar. A personagem pressionada é aquela que cria, mergulhada na essência de seres que constituem suas próprias monstruosidades. O criador, também criatura, divide suas apreensões e medos, vivenciando, entretanto, a vida nas páginas 
que compõe. Desta feita, o escritor-personagem, após encontro na editora, vivencia sua própria escrita e nesse mundo o leitor de Viale Moutinho é convidado a percorrer essas relações insólitas. A história contada dentro da história é produtora de diferentes efeitos a serem descobertos por cada leitor que, astuciosamente, poderá desvendar quem são as personagens desse autor-personagem figurado na narrativa.

A vigésima oitava narrativa da obra de Viale Moutinho é a já citada "Negócios com o demônio" (139-140), que se configura pela ascensão das dúvidas e mesmo de questionamentos acerca da importância ou não de se fazer negócios com entidades não naturais. O texto revela, como em outras narrativas do autor, negócios efetuados pelo desconhecimento e também para safarse, ainda que momentaneamente, de algum inconveniente. Desse modo, o percurso textual revela descobertas a serem percebidas pouco a pouco no decorrer da leitura, possibilitando que se transbordem os limites da simples significação, ao extrair dados presentes nas tantas outras decodificações permitidas pelos negócios com o demônio.

O escritor José Viale Moutinho, na confecção de suas "Monstruosidades do tempo do infortúnio", instiga a que se abram bem os olhos para perceber, por meio de conhecimentos histórico e literário, a grandiosidade de suas composições narrativas. O autor contribui, claramente, para a ampliação dos domínios dos monstros e das monstruosidades, já que, por vezes, nos seus mundos possíveis ficcionais seus leitores são convidados a percorrer as matrizes que moldam a natureza do monstro, seja ele humano ou não. 
Os tempos do infortúnio são produto e produtores de monstros, monstruosidades abjetas resultantes tanto do medo do devir fatídico, quanto da percepção do devir extremamente comum. Assim, as personagens configuram-se por meio do enfrentamento com o mundo que as inquiri, conjugando em si o bem e o mal, ainda que confrontadas ou não por seres malignos. Nesse sentido, os mundos possíveis concebidos pelo escritor permitem múltiplas leituras que, certamente, devem explorar os limites da intertextualidade e da própria configuração dos níveis narrativos, visto que há textos que caminham nos limites tênues existentes na composição de narrativas de encaixe.

As monstruosidades propostas por Viale Moutinho não se dão apenas no âmbito da configuração de monstros já conhecidos ou na constituição de seres míticos, mas na percepção dos caminhos que a monstruosidade constrói tanto no humano como no não humano. O natural e o sobrenatural ou não natural das histórias escritas pelo autor enveredam pelos caminhos do insólito e, também, pela subversão e ruptura próprias do fantástico, transmutando a realidade de personagens também compostas para extrapolarem limites, testando, inclusive, as fronteiras de seus tempos do infortúnio.

Tem-se, pois, monstros e monstruosidades produzidos em tempos contínuos e desconhecidos, em narrativas marcadas pela intertextualidade e riqueza de elementos míticos e históricos. A demanda designada ao leitor foca, desse modo, em buscar mais informações sobre aquilo que lê. A narrativa tensiona os limites das monstruosidades, do fazer literário e, em certo sentido, dos percursos investigativos de modo geral. Os mundos possíveis 
ficcionais de Viale Moutinho instituem-se, portanto, a partir de traços do insólito, permitindo ao interdito uma intervenção precisa em quotidianos corriqueiros. As histórias clarificam circunstâncias específicas que, porém, ganham outra luminosidade ao perpetuarem certa angústia ou questionamento até depois de ter-se virado a página.

Constituem-se, nesse sentido, monstruosidades ainda a serem investigadas, descritas e pesquisadas. $E$, assim, em busca de novos caminhos, trilhar os tempos do infortúnio nem tão distantes da realidade de cada um e de todos os leitores, capazes, então, de combater e reconhecer seus monstros e monstruosidades, principalmente em seu mau vizinho.

\section{REFERÊNCIAS:}

LOVECRAFT, H. P. (2007). O horror sobrenatural em literatura. São Paulo: Iluminuras.

SILVA, Luciana Morais da (2016). Figurações da personagem e o universo insólito nos novos discursos fantásticos: narrativas curtas de Murilo Rubião, Mário de Carvalho e Mia Couto. 216p. (Tese - Doutorado em Letras) - Instituto de Letras da Universidade do Estado do Rio de Janeiro, Rio de Janeiro, Brasil; Faculdade de Letras da Universidade de Coimbra, Portugal. In https://estudogeral.sib.uc.pt/ handle/10316/39121\# Acesso em: 18.Mar.2018.

VIALE MOUTINHO, José (2018). Monstruosidades do tempo do infortúnio. llustração Alberto Péssimo. Lisboa: Letras e Coisas. 


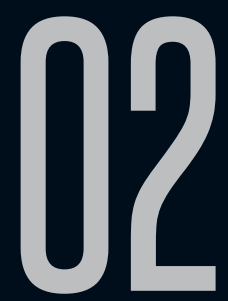

\section{ONZE HISTÓRIAS E UM SEGREDO: DESVENDANDO AS LENDAS AMAZÔNICAS. TAÍSA APARECIDA CARVALHO SALES. 2016}

Jamille da Silva Santos (UFU)

Recebido em 02 mai 2019. Jamille da Silva Santos é Doutoranda em Estudos Aprovado em 08 mai 2019. Literários da Universidade Federal de Uberlândia UFU. Mestre em Linguística pelo programa de Pós graduação em Lingüística - PPGlin da Universidade Estadual do Sudoeste da Bahia (2014). Possui Especialização em Lingua Brasileira de Sinais (LIBRAS) pelo Claretiano Sistema de Ensino (2018). Possui graduação em Letras Vernáculas pela Universidade Estadual do Sudoeste da Bahia (2012), Campus de Vitória da Conquista - Bahia. É membro dos Grupos de Pesquisa: Estudos sobre o Discurso e o Corpo grudcorpo/CNPq e do Grupo de Pesquisa em Espacialidades Artísticas GPEA / CNPq. Membro do LABEDISCO - Laboratório de Estudos do Discurso e do Corpo. 
O livro Onze histórias e um segredo: desvendando as lendas amazônicas, publicado no ano de 2016, foi organizado pela Professora Ms.a Taisa Aparecida Carvalho Sales - professora, em exercício provisório, de Libras e Tradução no curso de Letras da Universidade Federal de Goiás (UFG) e efetiva da Universidade Federal do Amazonas (UFAM) - em conjunto com os alunos do 40 período

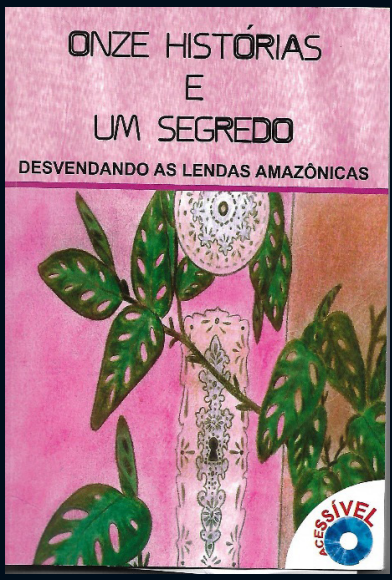
de Letras/Libras da UFAM. Essa coletânea foi escrita pelos alunos como uma proposta apresentada na disciplina "Literatura em Libras", ministrada no ano de 2015.

Como resultado de tamanha dedicação, somos apresentados a um conjunto de onze lendas vinculadas à cultura da Amazônia, que são reescritas levando em consideração a cultura indígena e a cultura surda. As lendas trabalhadas na obra foram: "A cobra grande"; "Mapinguari"; "Lenda do Uirapuru"; "O boto cor-de-rosa surdo"; "Lenda da Vitória-Régia"; "A lenda da Mandioca"; "A lenda do Guaraná"; "A lenda do Pirarucu"; "A lenda da lara"; "Kauane uma guerreira surda" e "O amor faz nascer um povo: a lenda da Família Baré Surda". E, ao final do livro, ganhamos o segredo, que se trata de um glossário da língua de sinais escrita - SignWriting - contendo os principais vocabulários utilizados dentro da obra.

As lendas que foram apresentadas no livro supracitado são reescritas pelos autores levando em consideração as questões que envolvem a comunidade surda. Assim, somos apresentados a temáticas como a falta de aceitação do próprio surdo e de sua 
comunidade - família, tribo, sociedade na qual está inserido -, o lugar do surdo como um ser diferente que possui algum defeito e a dificuldade do surdo em se comunicar em sociedade. As lendas sempre trazem uma solução para tais dilemas, que, em sua maior parte, são resolvidos quando a comunidade indígena decide aprender a língua de sinais e inserir o surdo em seu ambiente. Recorrentes dentro da comunidade surda na sociedade, as dificuldades de se comunicar, de se fazer entendido e entender o outro têm sido uma luta constante, juntamente com a aceitação da língua de sinais como primeira língua e o português como segunda língua escrita para o surdo.

A cada passagem de página, vemos o cuidado na realização e adaptação da obra para que essa não apenas apresentasse a cultura surda, como também fosse acessível para a comunidade surda. A obra é apresentada em quatro formas distintas, o Português que é colocado primeiramente, sendo esse diagramado em uma fonte maior do que costumamos encontrar em obras literárias, o que possibilita para o portador de baixa visão uma boa leitura; a segunda forma é a LIBRAS escrita - SignWriting -, que, apesar de ser uma forma de comunicação ainda pouco usada dentro da comunidade surda, a autora traz como possibilidade de leitura, apresentando o texto que se encontra em Português na LIBRAS escrita; a terceira versão se encontra em forma de vídeo, colocado dentro do livro por meio de um $\mathrm{CD}$, trazendo uma singularidade própria, pois exibe as quatro formas de comunicação em sua apresentação; as duas já mencionadas e a terceira propriamente dita, que é a narrativa oral feita por um locutor que relata o que aparece na tela em escrito; e, finalmente, a quarta, que diz respeito aos intérpretes sinalizando 
a narrativa na língua de sinais. Desse modo, na medida em que o texto aparece na tela em português e em SignWriting, juntamente com a imagem e com um intérprete sinalizando o que está sendo apresentado, a obra torna-se acessível para os surdos, cegos e surdos-cegos simultaneamente.

Outro fator de importante relevância dentro da obra são as ilustrações feitas por Edilson Morais e Silva, que complementam o texto escrito, o que é muito significativo para o surdo, pois, como sabemos, ele é extremamente visual e, por isso, todas as contribuições, como a sinalização e as ilustrações, são importantes para a compreensão textual, já que, em sua maioria, eles não possuem uma total fluência no Português, que deve ser sua segunda língua.

A primeira adaptação a que somos apresentados é da lenda "A Cobra Grande", realizada por Arlice Lopes Monteiro, que narra a história de Taiguara e Ubiraci, irmãos que eram amaldiçoados por serem gêmeos. De acordo com a lenda, as tribos indígenas acreditavam que gêmeos traziam azar para toda a tribo e, sendo assim, todas as vezes que nasciam gêmeos eles deveriam ser mortos para afastar qualquer maldição para aquela comunidade indígena. Dessa maneira, os gêmeos são jogados no rio para morrer, mas são salvos pela correnteza que os leva para a margem, onde crescem. Apesar de sobreviventes, os irmãos carregam marcas pelo fato de terem nascido ao mesmo tempo: Taiguara se transforma em cobra grande nas noites de lua cheia e sai devorando pessoas e virando embarcações; sua irmã Ubiraci nascera surda e, como não conseguia se comunicar com as pessoas a sua volta, vivia sempre afastada e revoltada com todos ao seu redor. No entanto, 
a maldição de Taiguara pode ser rompida desde que ele realize um ato de bondade com algum familiar, o que ocorre quando ele descobre uma comunidade indígena surda, aprende a língua de sinais e a ensina para sua irmã, que consegue se comunicar com seus semelhantes e passa a se sentir aceita e inserida socialmente.

A segunda lenda é a do "Mapiguari", reescrita por Rubens Mesquita da Silva Junior, que relata a vida de Teça, um indiozinho que nascera surdo e, por esse motivo, não consegue se comunicar com sua tribo, mesmo sendo aceito por ela, pois o Cacique acredita que Tupã, em sua sabedoria, fez todos diferentes e que as diferenças trazem qualidades que devem ser respeitadas. Entretanto, o Cacique não consegue fazer com que Teça se sinta inserido dentro da comunidade e, com o passar do tempo, o indiozinho fica mais solitário e revoltado por não conseguir ouvir e falar com sua tribo. Em uma tentativa de vocalizar, Teça começa a emitir sons altos e agudos que incomodam a todos e, conforme o índio cresce, esses sons se tornam mais altos e constantes, ficando insuportável para toda a tribo, que pede auxílio a Tupã para resolver o problema. Desse modo, o deus aparece em sonho para Teça e explica que ele é surdo e que possui uma linguagem própria. Deus começa a ensinálo, porém o índio se recusa e fica cada dia mais revoltado, levando a sua tribo ao desespero, de tal forma que Tupã resolve castigar Teça e o transforma em um monstro com um único olho e uma só boca que grita pela floresta, sendo chamado de Mapinguari. Porém, mesmo transformado em mostro, o índio não se conforma com sua situação, o que faz com que Tupã envie uma índia para enfeitiçá-lo e ensiná-lo a língua de sinais. Assim, Mapinguari se acalma e passa a ser o guardião da floresta guardando seu grito. 
A próxima narrativa é a "Lenda do Uirapuru", que tem sua adaptação feita por Sara Vitor Magalhães, e apresenta a história de Kaolin, filha do cacique da tribo que nascera surda. Um certo dia, a tribo de seu pai recebe a visita de um valente guerreiro, Teçá, que vem de uma tribo distante, onde os habitantes são surdos, e, ao serem apresentados, Teçá e Kaolin se apaixonam imediatamente, porém a índia já se encontrava prometida a outro guerreiro de sua tribo. No entanto, o amor dos dois era tão forte que eles desobedecem às ordens do Cacique e se encontram às escondidas, até o momento em que são descobertos e o cacique decide acelerar o casamento de sua filha com o guerreiro de sua tribo, expulsando Teçá. Porém, Tupã já aprovara a união de Teçá com Kaolin e decide transformar o seu pai em um passarinho para que possa deixar o casal ser feliz. Assim, Teçá e Kaolin se casam e se mudam para a tribo de Teçá, onde vive uma comunidade de índios surdos, e são felizes. $\mathrm{O}$ pai de Kaolin se metamorfoseia em Uirapuru e acompanha o casal para todos os lados cantando em forma de pedido de perdão.

"O Boto cor-de-rosa surdo" expõe uma adaptação realizada por Suelem Maquiné Rodrigues, que narra a vida de Inaiê, uma índia muito observadora que adorava passar os dias observando a paisagem a sua volta. Porém, Inaiê vivia sempre triste porque ela não conseguia se comunicar com as pessoas de sua tribo e não entendia como sua comunidade se entendia; ela percebia que gesticulavam a boca, porém não entendia nada, e a única pessoa com quem ela conseguia ter uma relação de entendimento era com sua mãe, pois as duas se utilizavam de gestos combinados entre elas para estabelecer uma forma de comunicação, mas a indiazinha vivia triste por não ser entendida e todos os dias se dirigia à beira do 
rio para chorar. Todavia, em certo dia, saiu do rio um moço muito bonito e encantador que deslumbrou Inaiê imediatamente, e esse moço se comunicava com as mãos, com o rosto, utilizando-se de todo seu corpo para se fazer entender. O tempo foi passando e os dois se encontravam todas as noites de lua cheia à beira do rio, e o moço ensinou à Inaiê a sua língua. No entanto, certo dia, o moço não apareceu mais, deixando a índia muito triste e solitária, até que se passaram as luas e ela descobriu que estava grávida. Um tempo depois nasceu um curumim surdo, um Apoema, o filho do boto, e para que seu filho não ficasse triste, Inaiê ensinou a língua de sinais para toda a tribo.

A quinta história apresentada é "Lenda da Vitória-régia", narrativa adaptada por Suelem Maquiné Rodrigues, que apresenta a vida de Naara, uma índia que nasceu surda. Por medo de ser amaldiçoada, sua mãe a entrega para o Pajé da tribo, que a cria como filha. Assim, Naara só consegue se comunicar com o Pajé e por meio de gestos combinados. Com medo de sofrer agressões da tribo por ser surda, Naara só sai para passear à noite, sendo as noites de lua cheia suas favoritas. No entanto, o Pajé começa temer o encanto que a índia tem pela lua e uma noite ele conta para ela a verdadeira história da lua, dizendo que na verdade se trata de um valente guerreiro, Jaci, e que as estrelas são suas namoradas. Ele conta que, como Jaci é muito vaidoso, ele costuma conquistar as moças mais bonitas e levá-las para viver com ele em forma de estrelas. Todavia, Naara já estava apaixonada pela lua e, em certa noite, Tupã permite um encontro entre os dois enamorados, o que faz com que ela se apaixone ainda mais e, a partir desse momento, a índia passa todas as noites em busca da lua, pedindo que ela a leve. 
Em uma noite de lua cheia, Naara se depara com o reflexo da lua no meio do rio e se joga atrás do seu amor e, desse momento em diante, nunca mais foi encontrada. No local em que o fato ocorreu, nasceu uma linda planta que foi nomeada de Vitória-régia.

A sexta narrativa apresentada é "A lenda da mandioca", escrita por Tereza de Jesus Albuquerque Moreira, por meio da qual somos apresentados à história de Mani, filha de índia com o deus Tupã. Em um certo dia, a filha do cacique aparece grávida sem saber de quem. A menina era prometida ao deus Tupã, o que deixa seu pai furioso, sendo aplacada sua fúria só com a aparição do deus em sonho falando que a criança era especial e um presente dele para tempos difíceis. Porém a menina nascera surda e, para algumas tradições indígenas, qualquer deficiência é sinal de fraqueza, sendo necessário o sacrifício da criança. O Pajé, então, reúne a tribo, conta sobre seu sonho e decreta que Mani, a menina que nascera branca e surda, era protegida. Mas em uma certa manhã sua mãe a encontra morta em sua rede, o que deixa toda a tribo muito triste. Eles enterram a menina no meio da tribo em uma oca, e, com o passar do tempo, no local em que Mani foi enterrada nasce uma planta nunca vista, que possuía uma raiz branca e saborosa, nomeada de Mani oca, que significa transformação de Mani. No futuro, tornou-se a mandioca, um alimento típico das tribos em todo o país.

A próxima narrativa adaptada é "A lenda do guaraná", feita por Eduardo de Souza Melo. O autor apresenta uma narrativa que se passa dentro da tribo Maués, onde um casal deseja muito ter um filho e não consegue. Após várias tentativas, eles pedem a Tupã que lhes conceda a graça. Pouco tempo depois, eles recebem a 
dádiva de ter um lindo menino, Cauê - aquele que é bom e age com inteligência -, que fora agraciado por Tupã com o dom de conversar com animais e plantas e ajudar a todos eles, tornando-se muito querido. Assim, por ser muito amado, Cauê desperta a inveja de Jurupari, deus da escuridão, que resolve tomar o dom dado por Tupã. Então, em um susto, ele deixa o menino sem ouvir e sem falar, de modo que Cauê não consegue mais se comunicar com a floresta nem com sua tribo, o que o deixa, assim como todos ao seu redor, muito triste. Não aguentando ver a tristeza que tomara conta da floresta, Tupã resolve agraciar Cauê com o dom das línguas de sinais para que ele pudesse, novamente, comunicar-se com todos a sua volta. Desse modo, sua tribo aprende a língua de sinais, e a paz volta para a tribo. Com o passar do tempo, Cauê morre, e Tupã resolve homenageá-lo, fazendo brotar uma árvore nunca vista na região, com frutos vermelhos e olhos bem pretos iguais ao índio: a árvore do guaraná.

A lenda a seguir foi reescrita por Francisco Pereira de Amorim com base na história do Pirarucu. O Pirarucu era um grande guerreiro indígena conhecido por sua valentia, mas também por sua vaidade e arrogância, principalmente com os que eram diferentes. Em sua tribo, existia um índio surdo, o lberê, e Pirarucu acreditava que ele não merecia o dom da vida por ser diferente de todos ali. No entanto, Iberê possuía o dom de se comunicar com os deuses e, utilizando-se desse dom, ele pede a Tupã que resolva a situação com Pirarucu, uma vez que ele não aguentava mais ser desrespeitado e agredido. Após algumas tentativas de conversa sem resultado, Tupã resolve castigar o Pirarucu e lança sobre a terra uma terrível tempestade que arrasta o índio para o rio, 
local em que o deus o transforma em um peixe grande, escuro, de cabeça chata e calda vermelha e que serviria de alimento para os outros. Em seguida, como forma de proteger lberê, Tupã o guia para uma tribo que possuía pessoas surdas e que aceitavam e se comunicavam por meio da língua de sinais.

A nona lenda apresentada narra a história da lara, e a adaptação é realizada por Jéssica Amaral Morais, que relata o nascimento de uma linda indiazinha, filha do Cacique e uma guerreira; a menina assim que cresce começa a chamar a atenção para os seus dons de caça. Como ela era surda, isso a tornava extremamente silenciosa e hábil com as mãos e olhos, de modo que ela conseguia as melhores caças, o que despertou a inveja em seus três irmãos que, consumidos por esse sentimento, resolveram dar sumiço com a índia. lara, tomada de raiva dos irmãos, vai até a árvore grande e gesticula, pedindo que ela resolva a situação com eles. Ela arranca um galho e com ele faz um chá e oferece para seus irmãos. No outro dia, eles somem, e em seus lugares crescem três árvores. Iara, sentida pelo o ocorrido, corre até árvore, gesticulando para que ela traga de volta seus irmãos e que ela seja punida, não eles. Logo em seguida, os irmãos voltam à forma normal, e lara se transforma em uma linda sereia que habita o Rio Amazonas.

A próxima releitura é "Kauane, uma guerreira surda", feita por Lilian Araújo Cerqueira, que conta a história de uma tribo guerreira constituída somente por mulheres. Dentro dessa tribo, não era permitida a presença masculina, e lá vivia Kauane, uma linda indiazinha surda que sonhava em ser guerreira, porém, por causa da surdez, ela não conseguia se comunicar com as outras guerreiras, que não a aceitavam nos treinamentos. Mas Kauane 
insistia e treinava sozinha, até que, certo dia, enquanto treinava, foi vista por Acauã, um guerreiro surdo que a observava, mas não sabia como ajudar. Ele vinha de uma tribo onde vários índios eram surdos e a língua de sinais era respeitada, porém, como ele não podia se aproximar de Kauane, não tinha ideia de como ensinar a ela a língua. Certo dia, pediu auxílio a Tupã, que mostrou a imagem do índio em sonho para Kauane, fazendo com que ela não o expulsasse quando o visse, e foi o que aconteceu. Assim, os dois ficaram amigos e ele ensinou a língua de sinais para ela, que repassou para todas as índias e fez com que elas a respeitassem como guerreira. No entanto, como sua tribo não aceitava a presença masculina, Kauane resolveu ir embora com Acauã para a tribo dele, onde foram felizes.

A última lenda adaptada é "O amor faz nascer um povo: a lenda da família Baré surda", reescrita por Nara Neiva Araújo Costa. A narrativa conta a história de um europeu escrivão da Companhia Francesa que, em passagem pelo Brasil, encanta-se com as belezas das índias e foge de sua embarcação, porém vai parar em uma tribo unicamente feminina que resolve se beneficiar de sua presença para procriação e, assim, o europeu, batizado pelas índias de Mir-bóia, se deita com todas as índias da tribo, até a última, Tipa. Eles começam uma relação, e logo Mira-bóia descobre que Tipa é surda. Como conhecedor das línguas de sinais francesas, ele resolve ensinar para ela e, com a convivência, os dois se apaixonam e resolvem fugir juntos para a nascente do Rio Negro, e lá se estabelecem e geram um filho, Baré, sendo os descendentes de Baré os fundadores da cidade de Manaus.

Por último, somos presenteados com uma surpresa que, como já adiantamos, trata-se de um glossário do português para 
- SignWriting, contendo algumas palavras utilizadas dentro das narrativas, possibilitando uma melhor leitura além de conhecimento da língua escrita de sinais.

A obra é classificada como acessível e desenvolve muito bem essa função quando busca trazer de várias formas as adaptações das lendas amazônicas para a comunidade surda, mostrando, dentro das narrativas, questões caras para a comunidade, como a comunicação, ou a falta de comunicação, o preconceito por parte dos ouvintes, o pensamento de inutilidade em relação ao surdo, a aceitação da língua de sinais como primeira língua do surdo e, só depois e por meio dela, o aprendizado do português escrito. A obra busca mostrar, por meio das releituras, a dura realidade da comunidade surda e algumas formas de resolução desse impasse. Em todas as narrativas existe um final feliz, e esse é o final feliz tão desejado pela comunidade, um final em que existam mais narrativas dessa forma e uma aceitação do surdo. 


\title{
NÓS, CIBORGUES: O CORPO ELÉTRICO E A DISSOLUÇÃO DO HUMANO ANTROPOLOGIA DO CIBORGUE: AS VERTIGENS DO PÓS-HUMANO - DONNA HARAWAY, HARI KUNZRU, TOMAZ TADEU (ORG.). 2016
}

\author{
Lilliân Alves Borges (UFU) \\ Tamira Fernandes Pimenta (UFU) \\ Marcus Vinícius Lessa de Lima (UFU)
}

Recebido em 03 mai 2018. Lilliân Alves Borges é doutoranda em Estudos Literários Aprovado em 10 mai 2018. na Universidade Federal de Uberlândia- UFU. Vicelíder do Grupo de Pesquisas em Espacialidades Artísticas/CNPq. Membro do Nós do Insólito: vertentes da ficção, da teoria e da crítica- UERJ. Estudos com ênfase no espaço literário, narrativa fantástica, com interesse especial sobre a obra de Graciliano Ramos.

Tamira Fernandes Pimenta é mestranda em Estudos Literários na Universidade Federal de Uberlândia. Graduada em Letras/ Português e suas respectivas literaturas pela UFU. Integrante do GPEA - Grupo de Pesquisas em Espacialidades Artísticas/ CNPq . Pesquisadora cadastrada na FAPEMIG com a pesquisa intitulada: " Como escrever uma vida: O insólito na escrita e pintura Kahliana". Atualmente é bolsista CAPES e tem seus estudos com ênfase em literatura e outras artes, com interesse especial na obra da pintora mexicana Frida Kahlo. 
Marx, Freud, Nietzsche, Heidegger. As revisões de Lacan e de Althusser. Foucault, Deleuze, Derrida, Lyotard e os pós-estruturalistas. Estudos feministas. Estudos culturais de raça e etnia. Estudos pós-colonialistas. A partir desse "breve" elenco de sistemas teóricos, vemos mapear-se mais de dois séculos de demolição do sujeito cartesiano e da subjetividade racional, reflexiva,

Donna haraway Hari KunZRI TOMAZ TADEu (Orc.)

Antropologia do ciborgue As vertigens do pós-humano autoconsciente: "não existe sujeito ou subjetividade fora da história e da linguagem, fora da cultura e das relações de poder" (TADEU, 2016, p.10).

Essa constatação é o ponto de partida e a base do pensamento que se descortinará na leitura dos quatro textos presentes no volume Antropologia do ciborgue: as vertigens do pós-humano, organizado e traduzido por Tomaz Tadeu (que assina também o primeiro ensaio). O livro contém ainda o relato de uma entrevista a Donna Haraway, conduzida por Hari Kunzru, além de uma tradução do canônico "Manifesto ciborgue" de Haraway, e um breve ensaio final também assinado por Kunzru.

A ruína conceitual do sujeito não é uma questão inédita, e os esforços contemporâneos abundam para pensá-la. Mais próxima ao âmbito da produção estética, Eliane Robert Moraes traz um exemplo desses esforços, ao investigar o problema da desfiguração do corpo humano e do desvio em relação à lógica antropomórfica na arte e no pensamento franceses do final do século XIX ao 
entreguerras $^{1}$. No campo editorial de vulgarização científica, em breve ensaio publicado na Revista CULT, Eduardo Leal Cunha, ao comentar a respeito das diversas configurações contemporâneas da homossexualidade, sugerirá que o colapso de uma identidade específica pode ressoar muito além, representando, na verdade, uma ruptura com a própria noção de identidade como elemento estruturante e organizador de um pensamento:

A suposta crise da identidade masculina poderá ser referida [...] ao colapso da própria lógica identitária, representada paradoxalmente pelo modo como as identidades e suas fronteiras se multiplicam continuamente [...], tornam-se inevitavelmente instáveis e incapazes de oferecer a segurança ontológica que nos prometiam. (CUNHA, 2019, p.27)

Já Paul B. Preciado alcançará pontos mais próximos ao que pretendemos comentar, abordando reiteradas vezes em seus estudos a industrialização, a máquina, a tecnologia (concebida como uma ordem anatômico-política de poderes, conceitos, saberes e transformações). Em meio às propostas de uma prática e uma teoria contrassexual, o autor interpelará inclusive as reflexões mais centrais de Antropologia do ciborgue:

[O] ciborgue não é um sistema matemático e mecânico fechado, mas um sistema aberto, biológico e comunicante. O ciborgue não é um computador, e sim um ser vivo conectado a redes visuais e hipertextuais que passam pelo computador, de tal maneira que o corpo conectado

1 MORAES, Eliane Robert (2017). O corpo impossível: a decomposição da figura humana: de Lautréamont a Bataille. 2.ed. São Paulo: Iluminuras.

2 Eduardo Leal Cunha. "A normalização das homossexualidades e os destinos do masculino". Revista CULT, 22(242). 
se transforma na prótese pensante do sistema de redes. (PRECIADO, 2017, p.167)3

O ensaio de Tomaz Tadeu - "Nós, ciborgues: O corpo elétrico e a dissolução do humano" -, passa ao largo das reflexões a respeito da/s sexualidade/s. Contudo, encontra larga margem de consonância à referência anterior, pois a questão central do autor é "onde termina o humano e onde começa a máquina?" (TADEU, 2016, p.10). A essa questão ele responderá comentando as transformações impostas ao corpo humano pela máquina: a ubiquidade do ciborgue, a interpenetração promíscua entre máquina e humano, a artificialização - mecanização e eletrificação - do humano, e a humanização subjetivação - otimizada da máquina.

O embaraço entre algumas fronteiras organizantes do pensamento ocidental também será apontado por Tadeu: o que separa ciência e política, tecnologia e sociedade, natureza e cultura? E, novamente, a questão colocada acima:

[S]e existe [...] uma criatura tecno-humana que simula o humano, que em tudo parece humana, que age como um humano, que se comporta como um humano, mas cujas ações e comportamentos não podem ser retroagidos a nenhuma interioridade, a nenhuma racionalidade, a nenhuma essencialidade, [...] então é a própria singularidade e exclusividade do humano que se dissolve. A ideia do ciborgue, a realidade do ciborgue [...] coloca em xeque a originalidade do humano. (TADEU, 2016, p.13-14)

As noções, ressonâncias teóricas e bases conceituais descritas acima correspondem ao território pelo qual os textos subsequentes

3 Paul B. Preciado. Manifesto contrassexual. São Paulo: n-1 edições. 
do volume se moverão. Responderemos, então, ao convite de Tomaz Tadeu (2016, p.14), e nos integraremos/plugaremos/ligaremos a essa corrente.

\section{"VOCÊ É UM CIBORGUE": UM ENCONTRO COM DONNA HARAWAY}

O jornalista e romancista britânico-indiano Hari Kunzru assina o texto seguinte, "Você é um ciborgue: Um encontro com Donna Haraway". Novamente o corpo humano interpelado e invadido pela tecnologia é o ponto de partida: "[q]uando a tecnologia atua sobre o corpo, nosso horror mescla-se, sempre, com uma intensa fascinação. Mas de que forma, exatamente age a tecnologia? E em que profundidade ela penetrou sob a membrana de nossa pele?" (KUNZRU, 2016, p.19). Em busca de respostas, Kunzru se volta para o bucólico Condado de Sonoma, Califórnia, às margens do Russian River, onde encontrará Donna J. Haraway.

Autora de obras como Gender, Race and Nature in the World of Modern Science (1989)e Simians, Cyborgs and Women: The Reinvention of Nature (1991) - ambas não traduzidas para o português -, Donna Haraway é mais conhecida no Brasil pelo impacto do canônico ensaio "Manifesto Ciborgue: Ciência, tecnologia e feminismo-socialista no final do século $X X^{\prime \prime 4}$. Enquanto professora de História da Consciência na Universidade da Califórnia, Santa Cruz, Haraway destacou-se como uma das poucas pensadoras a teorizar de forma contundente e sistemática a respeito das relações entre ciência, tecnológica e política, e entre a humanidade e as máquinas. Influenciadora do 
debate em áreas aparentemente tão diversas como a Primatologia e a Filosofia, também é referência nos debates contemporâneos a respeito de gênero, sexualidade e biotecnologia, e nome corrente nas reflexões do/s Feminismo/s, do Ciberfeminismo, da Bioética, da Engenharia Genética e dos Estudos Animais.

O relato de Hari Kunzru responderá, no volume em questão, a uma valiosa dupla operação. A princípio, dará voz a Donna Haraway para que explique, com certa dose de informalidade, pontos centrais da reflexão conduzida no Manifesto Ciborgue. Por exemplo, a respeito das conexões entre o ciborgue e as lutas feministas, Haraway afirma que

[a]s preocupações feministas estão dentro da tecnologia [...]. Estamos falando de coabitação: entre diferentes ciências e diferentes formas de cultura, entre organismos e máquinas. Penso que as questões que realmente importam (quem vive, que morre e a que preço) [...] estão corporificadas na tecnocultura. Elas não podem ser resolvidas de nenhuma outra maneira. (HARAWAY, Apud KUNZRU, 2016, p.28)

Além dessas explicações, introduções, e reflexões posteriores, uma série de exemplos bastante cotidianos virá somar-se àqueles já presentes no Manifesto: a pensadora comentará a respeito das redes político-biotecnológicas que unem a plantação de arroz, a imigração ilegal e a intoxicação por pesticidas. Ou ainda, a respeito da "interação entre medicina, dieta, práticas de treinamento, vestimentas e fabricação de equipamentos, visualização e controle do tempo" (HARAWAY, Apud KUNZRU, 2016, p.23), que transforma o esporte olímpico em uma rede tecnocultural internacional. 
A visita de Kunzru a Haraway suscitará também interessantes alusões a respeito da promiscuidade entre o discurso tecnológico e a linguagem chã do dia a dia. O jornalista menciona "uma surpreendente disposição", demonstradas pelos humanos dos anos 90, "para se compreenderem como criaturas conectadas entre si por meio de redes" (KUNZRU, 2016, p.27), ao que Haraway complementa:

[s]e começarmos a falar com as pessoas sobre como elas preparam seu jantar ou que tipo de linguagem utilizam para descrever problemas em seu casamento, é muito provável que obtenhamos respostas que se expressam em termos de circuitos, de quebra de comunicação, de ruído e sinal. (HARAWAY, Apud KUNZRU, 2016, p.27)

Outra potência relevante do relato de Kunzru avança um pouco mais em direção às estratégias de acessibilidade do pensamento conforme comentadas acima. Ao interpelar Donna Haraway em sua intimidade doméstica, caracterizando-a como alguém que mais se parece a "uma tia querida" (KUNZRU, 2016, p.20) que a um ciborgue, o relato colabora para dissolver a impressão do ciborgue como algo totalmente alheio e exterior a nós. Ao recuperar a trajetória acadêmica da pensadora, associando-a às mutações em seu pensamento e em seu modo de vida, Kunzru parece nos dizer que se essa mulher, sentada em sua varanda, bebendo cerveja e acariciando seu gato, dotada de um passado profissional, afetivo, político, se essa mulher tão semelhante a nós está convicta de ser um ciborgue, por que não haveríamos nós todos de sê-lo também? Afinal, o mundo de Donna Haraway é também o nosso: "um mundo de facções em guerra, ideologias em conflito, oposições em choque: o estado e o povo, o gay e o heterossexual, o capitalismo e 
o comunismo, o humano e o animal, as pessoas e as máquinas. [...] obviamente, uma loucura completa" (KUNZRU, 2016, p.32).

\section{MANIFESTO CIBORGUE: CIÊNCIA, TECNOLOGIA E FEMINISMO-SOCIALISTA NO FINAL O SÉCULO XX}

Donna J. Haraway afirma trazer um ensaio pleno de ironia e como a maioria das ironias -, causa incômodo, promove um esforço em compreender uma sociedade além dos paradigmas atuais de construção de relações. Haraway propõe uma sociedade para além da existência das fronteiras.

A figura do ciborgue proposta pela estudiosa trata-se de

um organismo cibernético, um híbrido de máquina e organismo, uma criatura de realidade social e também uma criatura de ficção. Realismo social significa relações sociais vividas, significa nossa construção política mais importante, significa uma ficção capaz de mudar o mundo. (HRAWAY, 2016, p.36)

O ciborgue advém da necessidade de refletirmos as fronteiras que demarcam nossa sociedade, isto é, de "imaginar um mundo sem gênero, que será talvez um mundo sem gênese, mas talvez, também, um mundo sem fim. A encarnação ciborguiana está fora da história da salvação" (HARAWAY, 2016, p.37-38). Colocase, portanto, em xeque as dicotomias. Anula-se os domínios de opressão, a estrutura social atual, em cujo cerne está o homem original como elemento primordial:

Com o ciborgue, a natureza e a cultura são reestruturadas: uma não pode mais ser o objeto de apropriação ou de incorporação pela outra. Em um mundo de ciborgues, as relações para se construir 
totalidades a partir de respectivas partes, incluindo as da polaridade e da dominação hierárquica, são questionadas. (HARAWAY, 2016, p.39)

É necessário, portanto, refletir a quebra das fronteiras a partir de três fronteiras cruciais: humano / animal, humano / máquina e físico / não-físico.

Ao colocar em xeque as dicotomias, Donna Haraway propõe pensar a definição de "experiência das mulheres", ou seja, o que demarcaria a categoria de "mulher". Há uma essência do sujeito mulher? Um conceito unificador e totalitário?

Haraway mostra como os feminismos socialista e marxista expuseram a não inocência da categoria "mulher", pois essa revela estruturas de dominação aprioristicamente definidas por um sistema hierárquico. Logo, é necessário compreender que "mulher" é um mito político. A partir daí, a estudiosa propõe refletir "mulher" não por meio de identidades e sim afinidades, pois as identidades são "contraditórias, parciais e estratégicas" (HARAWAY, 2016, p.47), criando, portanto, taxonomias infinitas que não agregam, e sim excluem. Logo, pensar em afinidades em vez de identidades é pensar em uma unidade política para "enfrentar, de forma eficaz, as dominações de 'raça', de 'gênero', de 'sexualidade' e de 'classe"' (HARAWAY, 2016, p.52). Com isso, o feminismo ciborgue tem "que argumentar que 'nós' não queremos mais nenhuma matriz identitária natural e que nenhuma construção é uma totalidade" (HARAWAY, 2016, p.52).

Os rearranjos das relações sociais desenvolveram uma possível unidade política enraizada nas demandas que apresentam uma diferença relativa no olhar populacional. Esse 
olhar, a priori caracterizado por uma sociedade que visava um sistema industrial estritamente voltado ao trabalho, passa pela transição de acoplar o lazer e a "informática da dominação" em suas vivências.

Essa transição é acompanhada por mudanças que regem o cenário da sociedade e englobam vários segmentos sociais, comportamentais e ideológicos. Ademais, com a evolução tecnológica, o imbricamento entre o real e o virtual acaba com o conceito de natural, conforme sustenta Dona J. Haraway.

Desse modo, as transformações etnográficas estão em constante movimento, o que não possibilita uma determinação ou planejamento, tornando os procedimentos adotados pelas estratégias de controle baseados em dados probabilísticos e estatísticos para "convencer" determinado grupo social. A pensadora destaca que, no caso das mulheres, a escolha por ser mãe carrega vários estereótipos:

[a] situação real das mulheres é definida por sua integração/ exploração em um sistema mundial de produção / reprodução e comunicação que se pode chamara de "informática da dominação". (HARAWAY, 2016, p.63)

Como apontado, esse conjunto de relações sociais e da tecnologia são cruciais nas relações vivenciadas diariamente por mulheres e demais grupos, pois remodelam os corpos por meio de ferramentas que são corporificadas ao seu cotidiano. Além disso, o fluxo de informações e controle que os indivíduos estão submetidos consiste em determinar um número cada vez maior de conteúdos compartilhados e produzidos. 
Outro aspecto destacado pela pensadora é a visão do corpo como um "sistema cibernético de comunicação", o qual se relaciona à situação reprodutiva da mulher, permeada pela intervenção de novas tecnologias e pela estética. Desse modo, destaca que "[o] bviamente saber quem controla a interpretação das fronteiras corporais na hermenêutica médica é uma questão feminista importantíssima." (HARAWAY, 2016, p.74). Assim a reformulação das expectativas e a obtenção do remodelamento corporal são fatores centrais para vivenciar os meios sociais e pessoais.

A princípio, verifica-se que, com o advento da "Nova Revolução Industrial", surgiram as novas divisões do trabalho, favorecendo o enfraquecimento dos agrupamentos familiares. Esse acontecimento envolve questões como consumo, produção, sexualidade, reprodução e foi nomeado por Richard Gordon como "economia do trabalho caseiro".

Essa nova modalidade caracterizada, em um primeiro momento, por estabelecer trabalhos direcionados apenas para o público feminino passa a ser executado também por homens. Em vista disso, os lugares de trabalho que anteriormente se reduziam a determinado gênero, passam a integrar uma nova escala na qual são repensados os papéis e as relações existentes na sociedade. De acordo com Haraway, isso "torna-se possível por meio das novas tecnologias, embora não seja causado por elas" (HARAWAY, 2016, p.70).

Com a descentralização da mão de obra, as consequências de novos arranjos econômicos e tecnológicos surgem devido à intensificação da pressão e da cobrança em relação aos papéis desenvolvidos por mulheres e a feminização da pobreza, advinda da 
maioria dos lares serem chefiados por mulheres que ganham menos que homens para desempenharem as mesmas funções, sendo responsáveis por suprir todas as carências, afetivas ou financeiras.

É importante destacar ainda que as mulheres negras sofrem mais nesse processo devido a várias questões, sendo a raça, a sexualidade e a classe os principais norteadores das consequências relativas às políticas de gênero e raça. Além disso, é notório que as condições a que estão submetidas são ainda piores do que as vivenciadas por mulheres brancas.

Adiante, a pensadora discorre sobre a fuga das mulheres negras dos serviços domésticos mal remunerados para a ocupação de cargos em escritórios e a pressão sofrida pelas adolescentes nas áreas industrializadas do Terceiro Mundo que são diretamente as provedoras da principal fonte de renda das famílias. Essas fases do capitalismo desencadearam posteriormente modelos problemáticos e desiguais na formação das famílias, sendo esses

1) a família nuclear patriarcal, estruturada pela dicotomia entre o público e o privado e acompanhada pela ideologia burguesa branca de separação entre a esfera pública e a privada e pelo feminismo burguês anglo- americano do século XIX; 2) a família moderna mediana (ou imposta) pelo estado de bem-estar e por instituições como o salário-família, com um florescimento de ideologias heterossexuais a-feminista, incluindo suas versões críticas desenvolvidas em Greenwich Village, em torno da Primeira Guerra Mundial; e 3) a "família" da economia do trabalho caseiro, caracterizada por sua contraditória estrutura de casas chefiadas por mulheres, pela explosão dos feminismos e 
pela paradoxal intensificação e erosão do próprio gênero. (HARAWAY, 2016, p.71-72)

Nesse contexto de divisão de grupos familiares, de acordo com Dona Haraway, as novas tecnologias desencadearam o desemprego estrutural a medida que a mão de obra humana foi substituída pela robótica e tecnologias que mecanizaram os trabalhos. O que afetaria também as relações sociais, os vínculos afetivos, a sexualidade e a reprodução.

Ademais, é apontado como a estrutura social é fortemente bimodal: de um lado altas tecnologias e um bombardeio de informações; de outro, uma grande quantidade de indivíduos que vivem à margem da sociedade, sem acesso à alfabetização e ao mercado de trabalho, em especial, a pensadora destaca, "pessoas de cor". Porém, esses indivíduos estão expostos e controlados por meios tecnológicos que vão das redes de entretenimento até os demais meios comunicativos disponíveis.

Acerca do contexto das mulheres no circuito integrado, Haraway sintetiza "a localização histórica das mulheres nas sociedades industriais avançadas, considerando que essas posições foram reestruturadas, em parte, por meio das relações sociais da ciência e da tecnologia" (HARAWAY, 2016, p.76). Ou seja, a imagem de uma rede ideológica que sugere uma profusão de espaços e identidades e a permeabilidade das fronteiras no corpo pessoal e no corpo político. A ideia de "rede" evoca tanto uma prática feminista quanto uma estratégia empresarial multinacional. Tecer é uma atividade para ciborgues oposicionistas.

Por fim, a estudiosa propõe-se a pensar novamente acerca do mito sobre identidades e sobre fronteiras, realizando um percurso 
sobre a questão dos dualismos: eu x outro, mente x corpo, cultura $\mathrm{x}$ natureza, machox fêmea, civilizadox primitivo, realidadexaparência. Com isso, demonstra que as ficções-científicas feministas sobre ciborgues têm a tarefa de recodificar a comunicação e a inteligência a fim de subverter o comando de controle das estruturas sociais.

\section{GENEALOGIA DO CIBORGUE}

Um outro texto de Hari Kunzru, "Genealogia do ciborgue", encerra o volume. Esse breve ensaio parte da inquietante constatação de que o primeiro ciborgue do mundo teria sido um rato de laboratório. Ao final dos anos cinquenta, como parte de um programa experimental no Hospital de Rockland, o animal teve uma bomba osmótica implantada em seu corpo, a qual injetava doses controladas de substâncias em seu organismo, visando provocar alterações em seu funcionamento fisiológico.

A definição de ciborgue, portanto, seria: "parte animal, [...] parte máquina" (KUNZRU, 2016, p.121). Essa primeira definição teria sido cunhada por Manfred Clynes e Nathan Kline, um engenheiro e um psiquiatra, os próprios inventores do termo "ciborgue". Em um artigo de $1960^{5}$, republicado em livro mais de três décadas depois, em $1995^{6}$, os autores atribuíam ao termo o ideal de "um homem melhor adaptado aos rigores da viagem espacial", cujo corpo constituiria um híbrido entre humano e máquina (KUNZRU, 2016, p.121).

As várias facetas do ciborgue serão também comentadas por Kunzru. Ao mesmo tempo projeto técnico, sonho científico,

5 CLYNES, Manfred E.; KLINE, Nathan S. "Cyborgs and space”. Astronautics, 5(9), 26-27; 74-76.

6 CLYNES, Manfred E.; KLINE, Nathan S. "Cyborgs and space”. In: The cyborg handbook. Nova lorque; Londres: Routledge. p.83-92. 
ideal militar, criatura de ficção científica e assunto do horário nobre televisivo, o ciborgue se encontrará em um espaço de tensionamento. De um lado, a possibilidade de fuga das limitações corporais humanas - ficcionalizada em figuras como o SuperHomem e o Capitão América -, de outro, o imaginário em torno de robôs, autômatos e seres artificiais, referidos desde o épico indiano Mahabharata, datando de 300 a.C. A tensão entre ficção, ideal científico, e prática científica de fato, incidiria no que vem a ser a realidade do ciborgue:

[u]ma máquina constituída de uma combinação e pulmão e coração [...] utilizada para controlar a circulação sanguínea de uma moça de 18 anos durante uma operação em 1953. Um homem de 43 anos [que] recebeu o primeiro implante de marca passo (sic.) em 1958. (KUNZRU, 2016, p.122-123)

Um marco divisório na história do ciborgue, segundo Kunzru, seria sua aproximação da tecnologia da informação, diferenciando-o de seus ancestrais mecânicos. O autor recorre a Haraway nesse ponto: os ciborgues "são máquinas de informação. [...] trazem dentro de si sistemas causais circulares, mecanismos autônomos de controle, processamento de informação - são autômatos com uma autonomia embutida" (HARAWAY, Apud KUNZRU, 2016, p.123).

Nessa esteira, ganham relevância a Guerra Fria, a cibernética e a figura do inaugurador dessa ciência, Norbert Wiener. O lançamento de seu Cybernetics, or control and commucation in the animal and the machine , em 1948, cunharia o termo "cibernética". Posteriormente, essa ciência seria identificada como aquela "que explicaria o mundo

7 WIENER, Norbert (1948). Cybernetics: Or control and Communication in the Animal and the Machine. Paris: Hermann \& Cie; Cambridge: MIT Press. 
como um conjunto de sistemas de feedback, permitindo o controle racional de corpos, máquinas, fábricas, comunidades e praticamente qualquer outra coisa", ou seja, "uma ciência universal da comunicação e do controle" (KUNZRU, 2016, p.124-125).

No ambiente da Guerra Fria, alimentados pelo ideal de superar as limitações do corpo humano, os pesquisadores de ciborgues teriam se empenhado em interpretar seus problemas sob a ótima da cibernética de Wiener:

O corpo era apenas um computador de carne, executando uma coleção de sistemas de informação que se auto-ajustavam em resposta aos outros sistemas e a seu ambiente. Caso se quisesse construir um corpo melhor, tudo que se tinha a fazer era melhorar os mecanismos de feedback ou conectar um outro sistema. (KUNZRU, 2016, p.125)

Kunzru finaliza sua genealogia descrevendo a dissolução da cibernética como ciência, vítima de suas próprias limitações, tais como a analogia completa e incoerente entre os mecanismos de controle e comunicação das máquinas, dos animais e da sociedade. Contudo, aponta o autor, serão vários os desdobramentos do sonho de Norbert Wiener de fundar uma ciência universal. Novas áreas surgiram, como as ciências cognitivas, pesquisas em campos como a Inteligência Artificial receberam maior atenção e investimentos, e sobretudo, dois resíduos culturais importantes foram deixados. De início, a "descrição do mundo como uma coleção de redes"; em seguida, a "intuição de que não existe uma distinção tão clara entre pessoas e máquinas" (KUNZRU, 2016, p.126).

Elucidativo a respeito do ciborgue que paira fantasmagoricamente por todo o volume Antropologia 
do ciborgue, o ensaio de Kunzru repete um esforço que já identificamos em sua entrevista a Donna Haraway. Dando relevo às juntas, próteses, implantes auditivos e óticos, à cirurgia cosmética, aos bancos de dados (como próteses para a memória humana), e ao mesmo tempo às tecnologias de otimização dos corpos-militares, o autor descortina o quanto de nós está nos ciborgues, e vice-versa, bem como quantas estranhezas tecnológicas passam ao largo de nossa reflexão cotidiana. 


\section{FABUSÕES}

